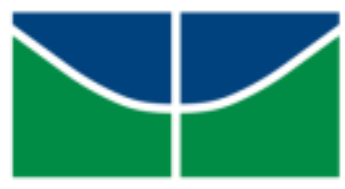

UNIVERSIDADE DE BRASÍLIA

FACULDADE DE COMUNICAÇÃO

PROGRAMA DE PÓS-GRADUAÇÃO EM COMUNICAÇÃO

MÍDIA, SOCIEDADE CIVIL E A DEMOCRATIZAÇÃO DA COMUNICAÇÃO: O CONFRONTO DE DISCURSOS DURANTE A CONFECOM

Jurema Maria de Sousa Baesse

BRASÍLIA

2015 
UNIVERSIDADE DE BRASÍLIA

FACULDADE DE COMUNICAÇÃO

PROGRAMA DE PÓS-GRADUAÇÃO EM COMUNICAÇÃO

MÍDIA, SOCIEDADE CIVIL, E A DEMOCRATIZAÇÃO DA COMUNICAÇÃO:

O CONFRONTO DE DISCURSOS DURANTE A CONFECOM

\author{
Jurema Maria de Sousa Baesse
}

Tese apresentada ao Programa de Pós-Graduação em Comunicação da Universidade de Brasília como requisito parcial à obtenção do título de doutora em Comunicação.

Orientadora: Nélia R. Del Bianco

\title{
BRASÍLIA
}


B139m Baesse, Jurema Maria de Sousa.

Mídia, sociedade civil e a democratização da comunicação: o confronto de discursos durante a

Confecom / Jurema Maria de Sousa Baesse. - Brasília: Universidade de Brasília, 2015.

282 p. ; 3 vol.

Tese apresentada em 3 volumes: vol. 1 - Trabalho Acadêmico; vol. 2 e vol. 3 - Anexos do Trabalho Acadêmico.

Tese (Doutorado) - Universidade de Brasília, Faculdade de Comunicação - Programa de PósGraduação em Comunicação.

Orientadora: Nélia R. Del Bianco.

1. Mídia. 2. Internet. 3. Confecom. 4. Democracia. I. Del Bianco, Nélia R. II. Universidade de Brasília - UnB. III. Título. 
JUREMA MARIA BAESSE

\section{MÍDIA, SOCIEDADE CIVIL E A DEMOCRATIZAÇÃO DA COMUNICAÇÃO: O CONFRONTO DE DISCURSOS DURANTE A CONFECOM}

Brasília, 29 de maio de 2015

BANCA EXAMINADORA:

Prof. ${ }^{a}$ Dra. Nélia R. Del Bianco (Presidente da Banca)

(Universidade de Brasília)

Prof. a Dra. Elen Cristina Geraldes

(Universidade de Brasília)

Prof. Dr. Fernando O. Paulino

(Universidade de Brasília)

Prof. Dr. Edgard Rebouças

(Universidade Federal do Espírito Santo)

Prof. Dr. Sérgio Euclides de Sousa

(Centro Universitário de Brasília- UniCEUB) 


\section{VERDADE}

A porta da verdade estava aberta,

mas só deixava passar

meia pessoa de cada vez.

Assim não era possível atingir toda a verdade,

Porque a meia pessoa que entrava

só trazia o perfil de meia verdade.

E sua segunda metade

Voltava igualmente com meio perfil.

E os meios perfis não coincidiam.

Arrebentaram a porta.

Derrubaram a porta.

Chegaram ao lugar luminoso

onde a verdade esplendia seus fogos.

Era dividida em metades

Diferentes uma da outra.

Chegou-se a discutir qual a metade mais bela.

Nenhuma das duas era totalmente bela.

E carecia optar. Cada um optou conforme seu capricho, sua ilusão, sua miopia.

(Carlos Drummond de Andrade) 


\section{AGRADECIMENTOS}

Agradeço, em primeiro lugar, à minha orientadora que começou a me acompanhar já no meio de um percurso bem acidentado, mas acreditou que era possível e conseguiu me empurrar para frente.

E em segundo lugar agradeço à minha pequena família, pelas horas de convívio que roubei de todos e à paciência que tiveram com minhas longas ausências. E quero fazer um agradecimento especial à minhas irmãs Jussara e Maria Inês que foram fundamentais na reta final do processo.

E agradeço, por fim, às minhas poucas e boas amigas que tinham sempre uma palavra de coragem e força para me ajudar a enfrentar a caminhada, com destaque para Francis, Cecília e Rosely. 


\section{RESUMO}

Este trabalho discute a construção de discursos de empresários do setor privado de mídia e de representantes das entidades sociais que defendem a democratização da mídia divulgados por meio de jornais e sites que cobriram a primeira e única Conferência Nacional de Comunicação (Confecom) ocorrida em Brasília entre os dias 14 e 17 de dezembro de 2009. A realização da Confecom possibilitou uma dupla oportunidade para que os dois lados da histórica luta sobre a democratização da mídia - o segmento privado do setor e os movimentos sociais - pudessem se encontrar e confrontar os seus discursos sobre a questão. Este encontro retomou impasses cristalizados durante A Constituinte de 1988 e não totalmente equacionados em 1995, durante as negociações que ensejaram na aprovação da Lei do Cabo (Lei 8.977), quando estes dois atores também se encontraram. A Confecom possibilitou um encontro ampliado entre estes dois lados que, ao longo dos últimos vinte anos se aproximaram e discordaram em questões mais pontuais, como a instalação do Conselho de Comunicação, a aprovação da Lei do Cabo, a não criação da Ancinav (Agência Nacional de Cinema e Audiovisual), a polêmica e insatisfatória legislação das rádios comunitárias, a decisão acerca da TV digital em desenvolvimento no Brasil, e a criação da Empresa Brasil de Comunicação (EBC). Nestes momentos, em que ocorreram alguns avanços e se solidificaram velhos entraves, os representantes de cada grupo buscaram ampliar espaços, marcar posições e construir um argumento discursivo que abarcasse o pensamento de cada lado e, ao mesmo tempo, convencer a sociedade de suas posições. Na Confecom não foi diferente. A Conferência foi mais um passo nessa trajetória e a presente pesquisa analisou como cada segmento utilizou essa oportunidade para se posicionar diante dos desafios trazidos pelo avanço da tecnologia, como também diante dos artigos do Capítulo da Comunicação preconizados pela Constituição de 1988 e até hoje ainda não regulamentados. A análise, feita a partir das matérias publicadas por três jornais brasileiros ( $O$ Globo, $O$ Estado de $S$. Paulo e a Folha de S. Paulo) e das matérias e artigos produzidos por dois sites ligados à entidades de defesa da democratização da comunicação, (Fórum Nacional pela Defesa da Democratização, e o Coletivo Intervozes) compreende os dez dias que antecederam a conferência e os dez dias posteriores, além dos quatro que durou o encontro. No confronto desses segmentos do setor de mídia - visibilizado pela cobertura - foi possível observar, por meio da aplicação da metodologia da Análise de Conteúdo e de Discurso que, assim como no cenário da elaboração da Constituição de 1988, os temas centrais e catalisadores voltaram à tona e, mais do que isso, os debates mexeram com as crenças, valores e a ideologia defendidos por cada um. Do ponto de vista discursivo os empresários buscaram reposicionar seu discurso histórico contra a democratização da mídia - e os movimentos sociais buscaram dar visibilidade à luta pela democratização. A análise tem como base os conceitos de hegemonia de Antônio Gramsci (1981, 2004), Norberto Bobbio (1988,2011,2012) e Carlos Nelson Coutinho (1981,1984,1992 e 1999); os conceitos de ideologia de Karl Marx(2001), Antônio Gramsci, John B. Thompson (1995), Marilena Chauí $(2001,2006)$ e outros; e os conceitos de sociedade civil de Antônio Gramsci, Norberto Bobbio, Carlos Nelson Coutinho) bem como os estudos de Manuel Castells (1999,2003, 2006, 2009 e 2013) acerca do impacto da tecnologia sobre a sociedade e as novas práticas sociais na contemporaneidade.

Palavras-chave: Mídia, Confecom, Discurso, Confronto, Regulação. 


\begin{abstract}
This work discusses the composing of speeches publicized by newspapers and by websites that covered the first and only National Conference of Comunication (Confecom), that occurred in Brasília between December 14 and December 17, 2009. The speeches examined are, on one side, those of businessmen of the media private sector and, on the other, those of the representatives of social entities that support the democratization of the media.The Confecom provided a double opportunity for the two sides of the historic battle on the democratization of the media -- the private segment of the sector and the social movements -to meet and confront their speeches on the issue. This meeting addressed impasses solidified during the Constitutional Assembly of 1988 and not totally resolved in 1995 during the negotiations between these same actors that resulted in the approval of the Cable Law (Law 8.977).The Confecom made possible an amplified meeting between these two sides which, over the last twenty years, both converged and diverged over more specific issues such as the installation of the Council of Communication, the approval of the Cable Law (cited before), the non creation of Ancinav (National Agency of Cinema and Audio-Visual), the controversial and unsatisfactory legislation of the community radios, the decision on digital TV to be implemented in Brazil, and the creation of the Brazil Enterprise of Communication (EBC). In these previous meetings, in which some advances occurred and some old impasses became more blocked, the representatives of each group sought to amplify spaces, to mark positions and to build a discursive argument that consolidated the thought of each side while, at the same time, to convince society of its own positions. Subsequently, at Confecom, it was not different. The Conference was one more step in this trajectory; and this research analyzes how each segment used this opportunity to position itself in face of the challenges brought by the advance of technology, as well as in face of the articles of the chapter on Comunication established by the Constitution of 1988 but not yet regulated until today. The analyses, based on the pieces published by three Brazilian newspapers ( $O$ Globo, $O$ Estado de São Paulo, and Folha de São Paulo) and the pieces and articles produced by two web sites connected to entities in defense of the democratization of Communication (National Forum in Defense of Democratization and the Coletivo Intervozes) span the ten days that preceded the conference and the ten days following it as well as the four days of the actual duration of the meeting. In the confrontation of these segments of the media sector - made visible by the coverage, it was possible to observe, through the methodology of The Analysis of Content and of Discourse that, in the same way as occurred during the elaboration of the Constitution of 1988, the central and catalyzing themes returned and ,moreover, shaped the beliefs, values and the ideology defended by each side. From the standpoint of the discourse, the businessmen sought to reposition their historical speech against democratization of the media -- and the social movements sought to give visibility to the fight for democratization. The analysis is based on the concepts of hegemony of Antonio Gramsci (1981, 2004), Norberto Bobbio (1988, 2011, 2012) and Carlos Nelson Coutinho (1981, 1984, 1992 and 1999); the concepts of ideology of Karl Marx (2001), Antonio Gramsci, John B. Thompson(1995), Marilena Chauí (2001,2006) and others; and the concepts of civil society of Antonio Gramsci, Norberto Bobbio, Carlos Nelson Coutinho, as well as the studies of Manuel Castells (1999,2003, 2006, 2009 e 2013) about the impact of technology on the society and of the new social practices of the contemporary age.
\end{abstract}

Key words: Media, Confecom, Discourse, Confrontation, Regulation. 


\section{LISTA DE QUADROS}

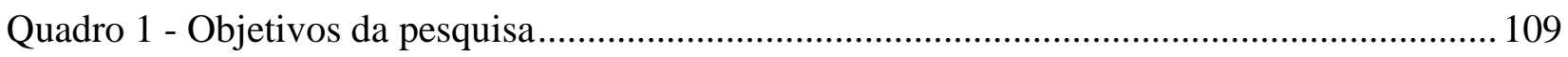

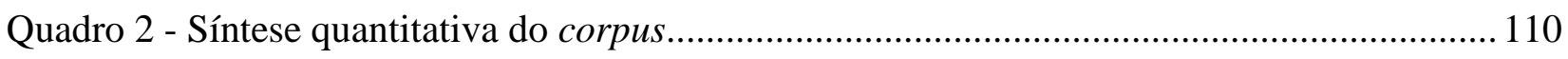

Quadro3 - Síntese do conteúdo do jornal O Estado de S. Paulo ................................................. 111

Quadro 4 - Síntese do conteúdo do jornal Folha de S. Paulo ..................................................... 111

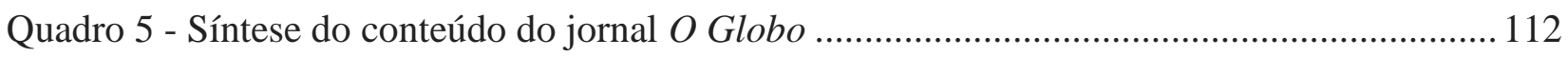

Quadro 6 - Síntese do conteúdo do site FNDC ....................................................................... 112

Quadro 7 - Síntese do conteúdo do site Intervozes ............................................................... 113

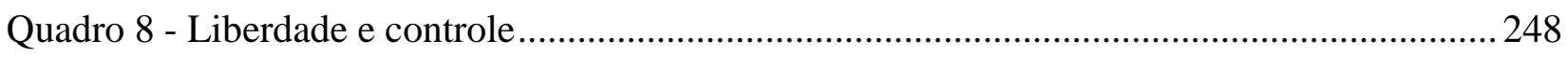

Quadro 9 - O marco regulatório ...................................................................................... 254

Quadro 10 - Acesso universal/participação social................................................................. 256

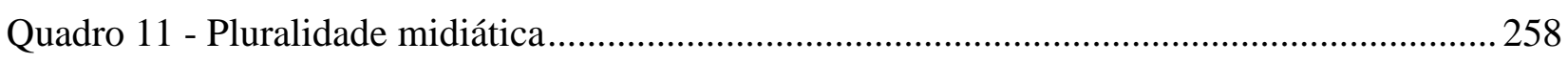

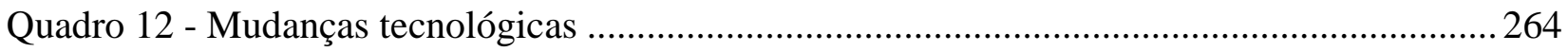




\section{SUMÁRIO}

INTRODUÇÃO

\section{CAPÍTULO 1}

A LUTA PELA DEMOCRATIZAÇÃO DOS MEIOS DE COMUNICAÇÃO ................ 19

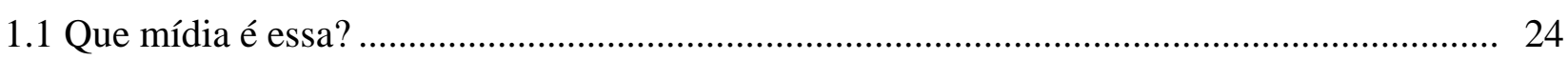

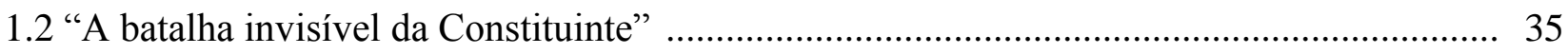

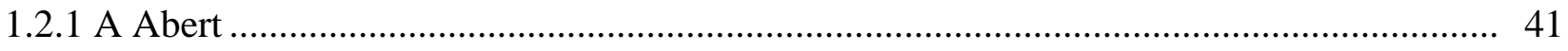

1.2.2 O palco da subcomissão da ciência e tecnologia e da comunicação ................................. 43

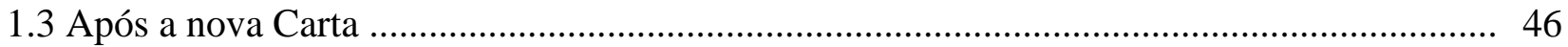

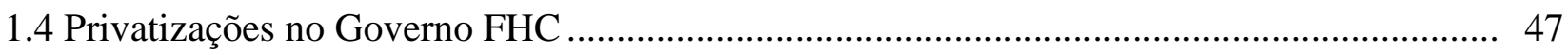

$1.5 \mathrm{O}$ começo da TV a cabo no país ............................................................................ 50

1.6 A curta história do Conselho de Comunicação Social ...................................................... .56

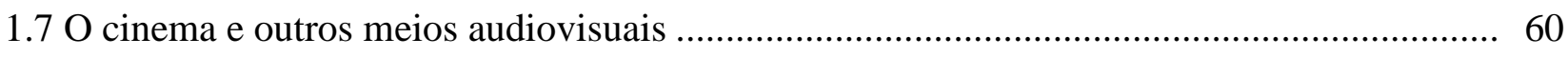

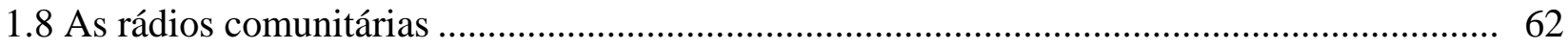

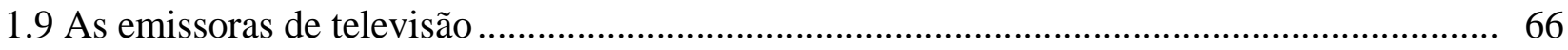

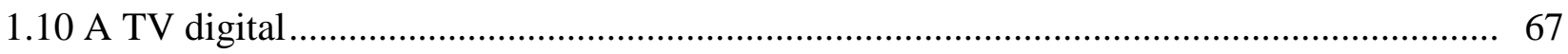

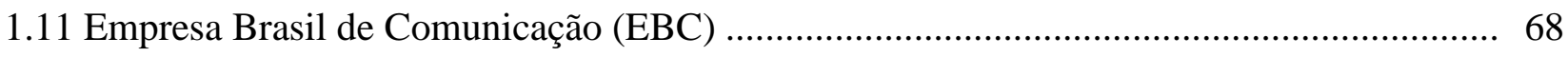

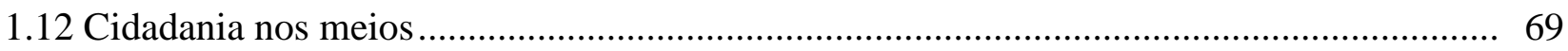

1.13 "Festival de Gambiarras" e o clima que antecede a Confecom ...................................... 71

\section{CAPÍtULO 2}

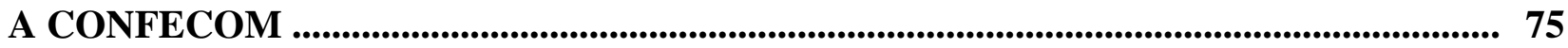

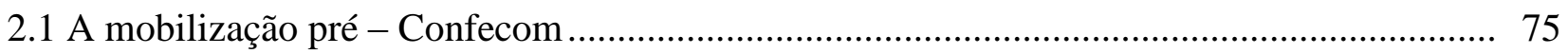

$2.2 \mathrm{O}$ anúncio da convocação da Confecom....................................................................... 83

2.3 A Conferência é oficialmente convocada......................................................................... 84

2.4 A saída parcial de empresários da Confecom.................................................................. 87

2.4.1 A nota dos empresários que saíram da Confecom ........................................................... 89

2.5 A realização das conferências estaduais ............................................................................. 91

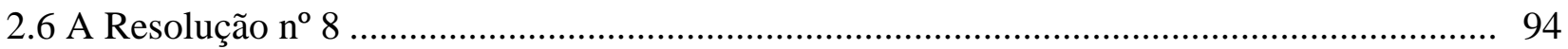

2.7 A abertura da etapa nacional da Conferência ................................................................ 94

2.8 Como aconteceu a etapa nacional da Conferência .............................................................. 96 
2.8.1 As discussões e votações nos GTs

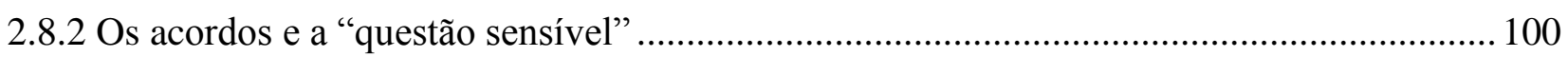

2.8.3 Síntese das propostas aprovadas pela Conferência.......................................................... 104

\section{CAPÍTULO 3}

OBJETO, PROBLEMA DE PESQUISA E JUSTIFICATIVA 105

$3.1 \mathrm{O}$ corpus da pesquisa.

\section{CAPÍTULO 4}

ABORDAGEM TEÓRICO METODOLÓGICA .................................................................. 115

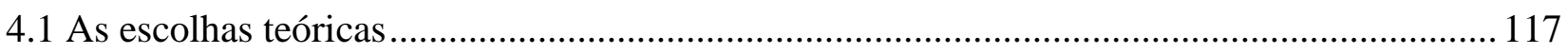

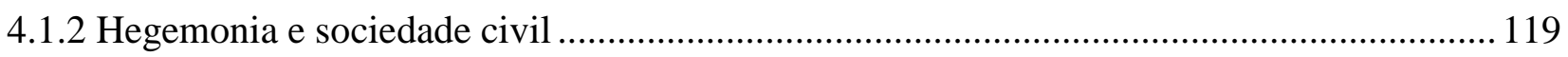

4.1.2.1 A coerção como elemento preponderante na dominação .............................................. 121

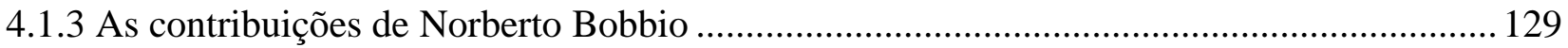

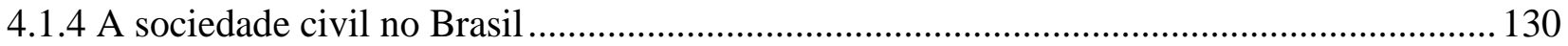

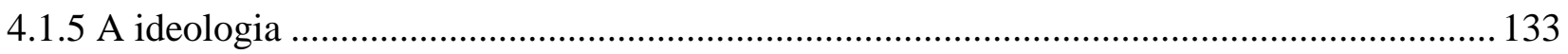

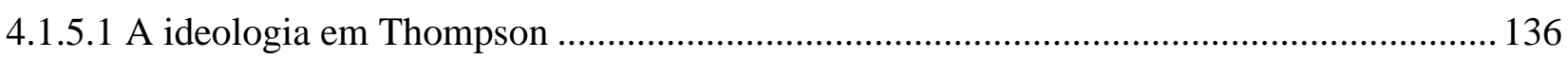

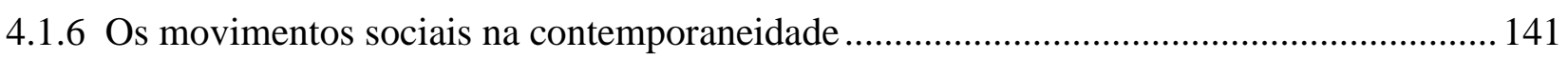

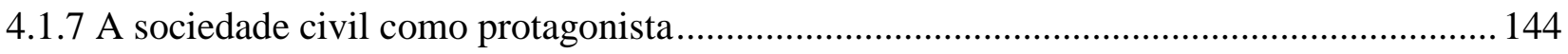

4.1.8 A nova comunicação em rede e seu impacto nas práticas sociais ...................................... 145

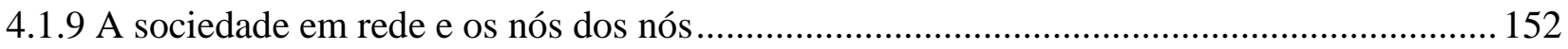

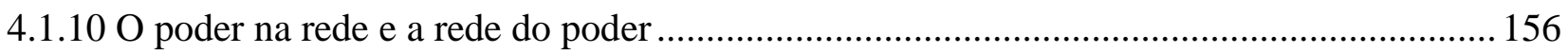

4.1.11 Autocomunicação e resistência .................................................................................... 159

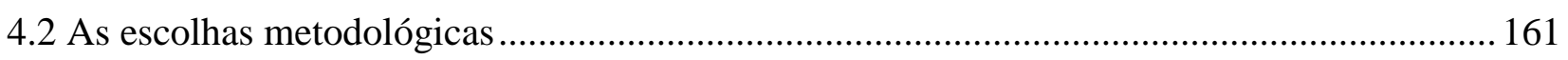

4.2.1 Formação discursiva dentro da Análise do Discurso........................................................ 162

4.2.2 A função da Análise de Conteúdo ....................................................................................... 164

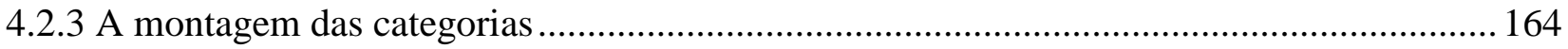

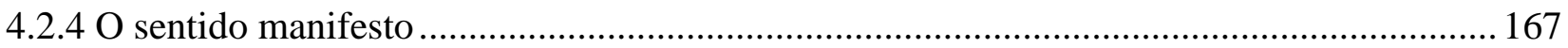

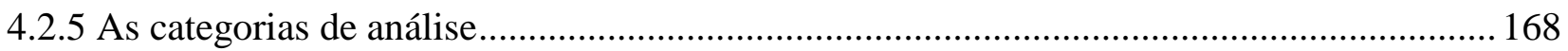

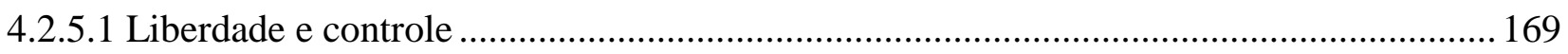

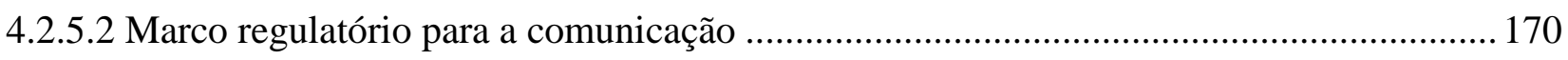

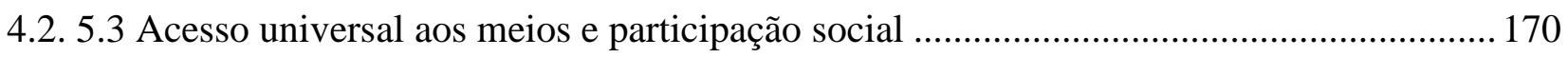

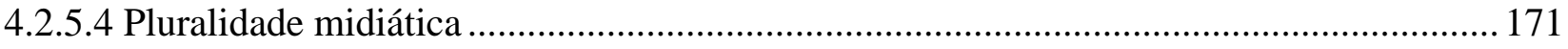

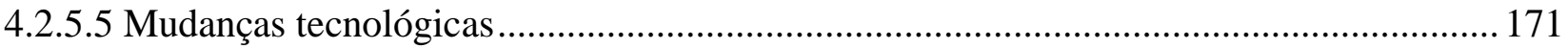


4.2.6 O jornalismo como lugar de produção de sentidos

\section{CAPÍtULO 5}

O EMBATE DISCURSIVO CONSTRUÍDO DURANTE A CONFECOM ......................... 177

5.1 Características gerais da cobertura da Confecom nos jornais e nos sites ............................. 178

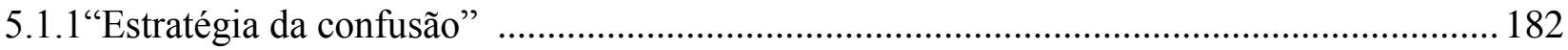

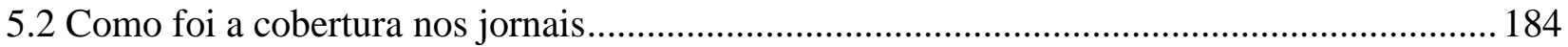

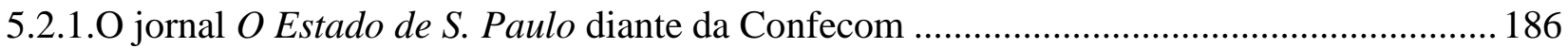

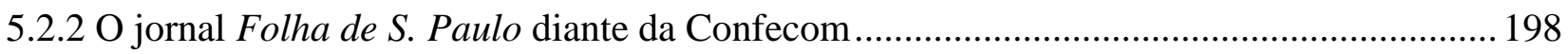

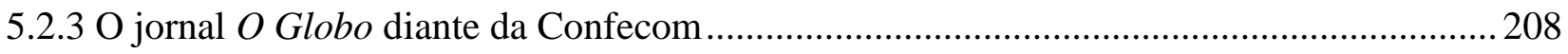

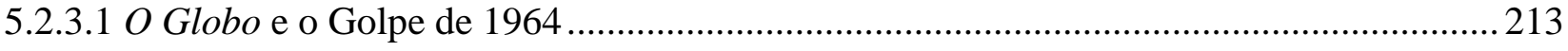

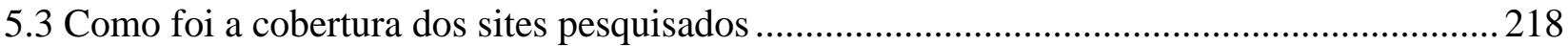

5.3.1 O Fórum Nacional em Defesa da Comunicação (FNDC) diante da Confecom..................222

5.3.2 O Coletivo Intervozes diante da Confecom.................................................................225

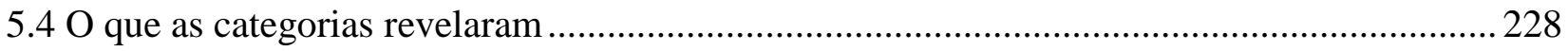

5.4.1 Liberdade de imprensa, de expressão e controle social da mídia ....................................... 228

5.4.2 Marco regulatório para a comunicação ......................................................................... 248

5.4.3 Acesso universal aos meios de comunicação e participação social.................................... 254

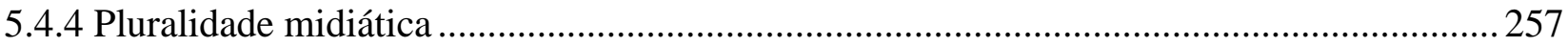

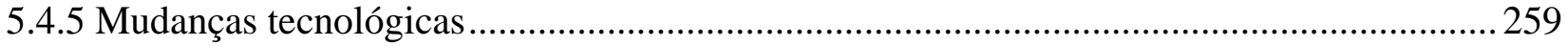

5.5 Por dentro das categorias temáticas - Uma síntese ............................................................ 264

CONCLUS ÃO

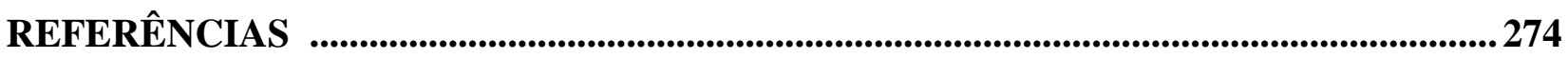

\section{ANEXOS (em separado)}




\section{INTRODUÇÃO}

Esta tese é o resultado da análise do aparato discursivo oriundo da Conferência Nacional de Comunicação (Confecom), materializado por editoriais, artigos, matérias e notas publicados por três jornais brasileiros ( $O$ Estado de S. Paulo, Folha de S. Paulo e O Globo) e por dois sites de notícias ligados ao movimento social pela democratização da mídia (FNDC e Intervozes). A pesquisa teve como objetivo desvendar os discursos extraídos do posicionamento de atores do campo da comunicação, de um lado as entidades civis e do outro os empresários privados do setor de mídia, que se confrontaram no cenário da Conferência. Este confronto se deu diante de propostas que tinham por objetivo a construção de uma nova regulação democrática da mídia no país.

A Confecom possibilitou um novo encontro histórico destes segmentos e gerou condições para a criação de um cenário propício ao confronto de ideias que apontam para caminhos opostos no que tange a regulação democrática dos meios. Enquanto os representantes do setor privado de mídia defendem mais liberdade e menos controle, os representantes dos movimentos sociais querem a presença do Estado para controlar os abusos cometidos pela mídia e a desconcentração do mercado privado. Cada um dos lados brigou para fazer prevalecer as suas posições ao mesmo tempo em que buscou angariar a simpatia da sociedade. Foi um duelo de discursos e posições sobre o qual a presente pesquisa se debruçou.

Cada um dos segmentos é dono de um discurso próprio que o caracteriza e o representa. A presente pesquisa parte do pressuposto que o discurso não existe solto ou isolado, ele pertence a alguém ou a um grupo, uma classe uma organização. É o discurso que constitui o sujeito como tal, é um efeito de sentido entre dois ou mais interlocutores. $\mathrm{O}$ discurso é o "lugar em que se pode observar a relação entre a língua e a ideologia" (ORLANDI, 2002, p. 43). A busca foi pela linguagem enquanto discurso, pois este traz a significação ao texto. A análise não se interessa apenas pelo texto, mas este permite que o analista tenha acesso ao discurso.

O fato de ter acontecido uma conferência em nível nacional, que chegou a mobilizar cerca de 30 mil pessoas ao longo de 2009, com a realização de prévias estaduais nos 26 estados e no Distrito Federal, com o objetivo de discutir o novo marco regulatório para o setor, diante das mudanças tecnológicas em curso, seria suficiente para justificar uma pesquisa acadêmica. Todavia, não é exatamente disso que se trata este trabalho. Este estudo é sobre a cobertura midiática dada ao evento, com foco no diálogo e embates que marcaram os 
dois segmentos da sociedade, historicamente adversários, visibilizados por meio das matérias e artigos publicados nos jornais e sites já citados.

São muitas as razões que podem ser apontados para justificar uma pesquisa com os propósitos aqui colocados, mas a maior reside no próprio acontecimento e na forma como ele foi mediado pelos meios de comunicação aqui estudados. A incredulidade quanto a sua realização, a resistência dos empresários da mídia tradicional em aceitar um debate dessa natureza e o ineditismo de uma conferência nacional para tratar de um tema tão complexo e, ao mesmo tempo, tão trivial e cotidiano como a comunicação, já seriam razões suficientes para um estudo desta natureza.

Depois do processo constituinte foi primeira vez que a comunicação foi colocada como pauta de discussão pública, com essa intensidade, no âmbito da Confecom, mesmo aos trancos e barrancos segundo Murilo Ramos, (2009). O que não significa que outros episódios, como a Lei de TV a Cabo de 1995 não tenham sido importantes para o conjunto da legislação que afeta os meios. A diferença é que a Conferência teve a pretensão de discutir as bases para uma nova regulação dos meios, tentando abarcar todas as questões mais polêmicas, como o controle social dos meios, a propriedade cruzada, os oligopólios, o uso da mídia para proselitismo religioso e a falta de estímulos e espaço para a produção cultural regional.

Outro diferencial na discussão do discurso sobre a Confecom é que, ao contrário de 1988, os movimentos sociais estavam muito mais organizados e fortalecidos, o que favoreceu a eclosão do debate. O professor Marcos Dantas (2010) considera que foi a primeira vez que o Brasil testemunhou um debate sobre a Comunicação, envolvendo segmentos tão amplos da nossa sociedade. Até mesmo parte dos empresários que boicotaram o evento e a "satanização" quase unânime por parte da grande mídia, a $1^{\text {a }}$ Confecom ampliou de forma inédita a mobilização da sociedade civil e o espaço público do debate sobre a comunicação no País. Segundo Pedrinho Guareschi (2013, p. 136), durante a preparação da Conferência foram realizadas mais de duas mil conferências estaduais, municipais, regionais e universitárias. Mais de duas mil propostas foram apresentadas, 633 foram aprovadas. Acima de tudo, a $1^{\text {a }}$ Conferência foi uma clara demonstração de que, por um lado, é possível construir uma comunicação democrática e participativa e, por outro, foi possível desvelar quem não quer participar do estabelecimento de uma comunicação participativa em nossa sociedade.

A ideia é que a partir da compreensão dos discursos que cada lado revelou seja possível avançar, nem que sejam alguns centímetros, no conhecimento dos atores que conformam o campo da Comunicação, e buscar elementos para entender por que a 
democratização da comunicação no País ainda é um assunto tabu, mas que deve ser revisto à luz das novas tecnologias.

A análise do discurso da mídia tradicional, representada pelos jornais $O$ Estado de $S$. Paulo, Folha de S. Paulo e $O$ Globo, e pelo que foi produzido pelos movimentos sociais e visibilizado nos sites do FNDC e do Coletivo Intervozes permitiu encontrar pistas sobre as condições sociais de produção desses discursos, as situações comunicacionais concretas que originaram e constrangeram os discursos, e a relação que os discursos estabelecem com a realidade a que se referem (SOUZA, 2004, p. 9).

Esta pesquisa buscou compreender as causas históricas que impedem que esses atores cheguem a um consenso acerca do novo marco regulatório para a comunicação do país. A Confecom foi um evento que criou as condições necessárias para o encontro destes dois lados da contenda e ofereceu oportunidade democrática para que cada segmento se colocasse e se posicionasse

A pesquisa trouxe um novo elemento à discussão a considerar que poucos trabalhos de pesquisa foram realizados sobre a Confecom. E dos que existem, a maioria tratou de discutir as propostas aprovadas e o possível impacto sobre o setor, caso fossem implementadas. Professores e escritores como Juarez Guimarães e Venício Lima (2013), e Pedrinho Guareschi (2013) incluíram em suas publicações recentes alguns comentários e avaliações sobre a Confecom. Todos eles reconheceram a importância da Conferência ter acontecido, apesar das dificuldades. Argumentaram que a sua realização foi mais um passo importante para a construção de um diálogo favorável a uma mídia com menor grau de oligopolização e mais participação popular

Nenhum dos artigos pesquisados tratou da herança discursiva deixada pelos personagens presentes à Confecom, nem tampouco sobre o confronto de discursos que se deu entre os atores da área da Comunicação.

O professor Marcos Dantas (2010) da UFRJ analisou os resultados da $1^{\text {a }}$ Confecom e fez um criterioso balanço das propostas apresentadas e aprovadas nos grupos de trabalho e na plenária geral. Além disso, explicou a dinâmica das votações, bem como alguns confrontos entre os representantes dos movimentos sociais e os empresários.

Os professores Valério Cruz Brittos, Bruno Lima Rocha e a pesquisadora Paola Madeira Nazário (2010, p. 13) destacaram a falta de "publicização do evento e a pouca agregação da sociedade no debate sobre os rumos da Comunicação Social no Brasil". Além disso, foram analisadas as consequências do modo de financiamento das empresas de comunicação, baseado nos aportes da publicidade comercial. 
Vale apontar, com destaque, o trabalho da pesquisadora Cecília Bizerra de Sousa (2014), que analisou atuação de movimentos negros na $1^{\mathrm{a}}$ Conferência Nacional de Comunicação, aprovada no início de 2014, e que trouxe valiosas contribuições para o presente estudo, especialmente com relação à mobilização observadas nos meses que antecederam a Conferência e também a efetiva participação de outras entidades sociais alheias ao campo da Comunicação propriamente. ${ }^{1}$

Outra contribuição coube aos pesquisadores Pedro Santono Zambon e Juliano Mauricio de Carvalho (2011) que abordaram o processo decisório e ação dos grupos de mídia, pelos professores que destacam que "a Confecom foi o maior evento realizado, desde a Constituição de 1988, de discussão sobre políticas públicas no setor da comunicação”. Nessa discussão foram analisados como os grupos envolvidos influenciaram no processo das decisões e votações dos grupos de trabalho. A pesquisa foi feita sobre os documentos produzidos no encontro e não sobre a cobertura da mídia.

Durante o Congresso Brasileiro de Ciências da Comunicação da Sociedade Brasileira de Estudos Interdisciplinares da Comunicação (Intercom), a professora Juçara Gorski Brittes (2013) apresentou pesquisa denominada "Estudo comparativo sobre políticas públicas de comunicação na América Latina", que tratou das políticas de comunicação no continente e lembrou as discussões durante a Conferência, com foco na necessidade de definição de um novo marco regulatório para o Brasil.

No seu estudo, Brites (2013) avaliou que a imprensa tradicional fez uma cobertura "esquizofrênica" da Confecom e que os jornais "apresentaram um cenário que só existe para os empresários". Baseada em entrevistas com participantes da Conferência, o artigo destaca que:

as raras notícias do mundo paralelo sobre a Conferência apenas repetiram uma ideia firmada desde a tentativa deste governo de criar uma agência reguladora do audiovisual, a Ancinave em 2006, reafirmada depois durante a tentativa dos jornalistas criarem seu conselho profissional. Nestas duas ocasiões, assim como havia acontecido no debate constitucional, em 1988, os empresários dos meios de comunicação hegemônicos, construíram uma lógica inversa afirmando que a tentativa de regular a mídia tinha, na verdade, o objetivo de amordaçá-la (BRITES, 2013, p. 8)

Nesse mesmo evento foi apresentado outro trabalho intitulado "O público na TV: discussões em rede nacional para a afirmação do sistema público no Brasil", coordenado por Raul Mourão Ruela e Iluska Maria da Silva Coutinho, ambos da Universidade Federal de Juiz de Fora. Nesse estudo, os resultados da Confecom são lembrados com foco na questão do

\footnotetext{
${ }^{1}$ Disponível em: <repositorio.unb.br/bitstream/10482/.../1/2014_CeciliaBizerraSousa.pdf>.
} 
fortalecimento da TV pública, que também foi tratado durante a Conferência de Comunicação, mas com o objetivo de valorizar e fortalecer a democracia dos meios.

Em todos esses estudos nada foi encontrado em relação ao tema desta investigação, que trata dos discursos hegemônico e contra-hegemônico construídos durante a Conferência Nacional de Comunicação, a partir da cobertura da imprensa e das matérias e artigos produzidos pelas entidades representativas da sociedade civil lá presentes.

Como todo trabalho acadêmico, este tem limites e recortes. Esta pesquisa deixou de fora, por exemplo, os enfrentamentos e disputas de bastidores que, certamente, aconteceram durante as reuniões que antecediam as votações, mas que não foram publicadas pela mídia, apenas foram relatadas pelos participantes do evento.

Também não foi feito aqui um trabalho de campo, de caráter mais etnográfico, que enfocasse os personagens presentes ao evento. Muitos deles poderiam dar uma contribuição importante sobre o que foi tratado, uma vez que muitos também estiveram presentes nos debates da Constituinte em 1987 e 1988. Mas isso seria um novo contexto e um paralelo com as ações de luta desenvolvidas naquela ocasião e as que estão sendo praticadas agora, a partir dos instrumentos oferecidos pela tecnologia.

Optou-se, em primeiro lugar, pela elaboração do contexto histórico em que se desenvolveram as batalhas pela democratização dos meios de comunicação desde a Era Vargas, com destaque ao período pós-64, tendo como esteio a história da mídia brasileira. Em meio a essas lutas foi construída a trajetória traçada pelos movimentos sociais que empunham a bandeira da democratização e do acesso universal aos meios, cujo desenrolar culminou na convocação da Conferência Nacional de Comunicação. A este primeiro Capítulo foi dado o nome de "Contexto Histórico da Luta no Brasil pela Democratização dos Meios de Comunicação".

Em seguida, veio o Capítulo Dois dedicado à Conferência. Foram apontados os primeiros esforços desenvolvidos pelas entidades para que a Conferência acontecesse desde 2005, quando o assunto passou a fazer parte da pauta nacional das entidades. E, em seguida, o desenrolar dos encontros preparatórios e das conferências estaduais, com destaque para a polêmica criada acerca do Regimento Interno do encontro.

No Capítulo Três foi detalhado o Objeto da pesquisa, com foco no discurso construído pelos movimentos sociais e pelos empresários privados do setor da mídia, tendo como cenário o palco da Conferência. Neste capítulo, foi apresentada a justificativa para a realização desta pesquisa, apontando para o fato de que - até então - pouco foi escrito sobre o legado 
discursivo da Confecom, além da pertinência do assunto para os estudiosos e pesquisadores do campo da Comunicação.

Para enfrentar os desafios de uma investigação sobre o discurso, foi feita uma abordagem teórico-metodológica focada nos estudos de Michel Foucault (1979), Dominique Maingueneau (2002, 2010) e Eni Orlandi (2002), além dos trabalhos de Laurence Bardin (1979) e Christian Laville e Jean Dionne (1999) sobre os suportes oferecidos pela Análise de Conteúdo. O referencial teórico - que foi fundamental para a compreensão dos conceitos medulares da tese, como ideologia, hegemonia e sociedade civil - foi construído com as contribuições de Antônio Gramsci (1981, 2004), Norberto Bobbio (1988, 2011, 2012) e Carlos Nelson Coutinho (1981, 1984, 1992 e 1999), além das noções fundantes de Karl Marx (2001). O referencial foi amparado, ainda, pelas análises de Manuel Castells (1999, 2003, 2006, 2009 e 2013) sobre o efeito da tecnologia nas pessoas e na sociedade conectada em rede, além dos estudos de Glória Gonh (2004, 2008, 2011 e 2012) acerca da nova face dos movimentos sociais na contemporaneidade.

E, por fim, no Capítulo Cinco, foram apresentados os resultados da pesquisa empreendida. A partir da construção do corpus com a categorização das unidades de análise extraídas dos discursos dos envolvidos na Confecom - foi possível avançar na análise. Os fragmentos de discurso extraídos foram sendo distribuídos entre as categorias criadas, de modo que cada uma delas trouxesse respostas às perguntas. Estas categorias trouxeram as posições de cada um dos lados sobre questões chaves como a liberdade de expressão e de imprensa, o marco regulatório que cada um defende, o acesso universal aos meios de comunicação e a pluralidade midiática; o que trouxe à superfície a resistência e obstáculos que cada segmento impõe para que uma nova regulamentação seja estabelecia. Foi possível enxergar o tamanho da distância entre estes dois lados, historicamente antagônicos, que dificulta a construção de um consenso em torno do debate.

A análise, por sua vez, indicou que os empresários do setor privado de mídia reiteraram o mesmo discurso contra a democratização da mídia que foi identificado durante a Assembleia Nacional Constituinte de 1988. Os movimentos sociais, por outro lado, mantiveram suas posições a favor de um novo marco regulatório em bases democratizantes, porém, não conseguiram criar um discurso atual e convincente para fazer frente aos argumentos defendidos pelos empresariados privado, como indica a Conclusão apresentada ao final da pesquisa. 


\section{CAPÍTULO 1}

\section{A LUTA PELA DEMOCRATIZAÇÃO DOS MEIOS DE COMUNICAÇÃO}

A mídia ocupa espaço central na construção simbólica da realidade e na formação de identidades na sociedade contemporânea. Não há como escapar da mediação da comunicação para a formação de valores morais e éticos ou para estabelecer a relação entre o Poder e a sociedade. As significativas mudança e complexidade nas relações entre a comunicação, a sociedade e o Poder têm de ser interpretadas a partir da compreensão de como a mídia se desenvolveu e se estabeleceu no Brasil, especialmente nos últimos 50 anos. Além de buscar definições que expliquem por que temos a mídia que temos, é preciso explicar que "a mídia ocupa uma posição de centralidade nas sociedades contemporâneas permeando diferentes processos e esferas da atividade humana, em particular a pública" (GUIMARÃES; LIMA, 2013, p. 11):

De acordo com esses autores, "um pressuposto para falar na centralidade da grande mídia (sobretudo a eletrônica) nas sociedades é a existência de um sistema nacional (network) consolidado de telecomunicações". Estar "centrada na mídia" é uma característica da maioria das sociedades contemporâneas. É o que está na mídia que dita, praticamente, as decisões que são tomadas diariamente por pessoas, empresas e o Governo. E é ela também que influencia a visão de mundo que cada um começa a ter da realidade que o cerca e o conforma, pois é ela que representa o que chamamos de realidade.

Para Guimarães e Lima (2013, p. 12),

O papel mais importante que a mídia desempenha decorre do poder de longo prazo que tem na construção da realidade, por meio da representação que faz dos diferentes aspectos da vida humana - etnias, gêneros, gerações, estética, valores, direitos e, em particular, da política e dos políticos.

A mídia carrega em si responsabilidades e atributos que explicam muito do País que temos hoje. Uma das maiores características dessa mídia permeia este estudo - seu caráter extremamente concentrado e pouco democrático. A concentração da mídia é reconhecida como um dos grandes empecilhos para que o processo de democratização da comunicação no Brasil avance. Para Tarso Genro,

As instituições privadas de comunicação que concentram maior poder econômico e comunicativo tanto na área das TVs como na dos jornais 
tradicionais, provocam o efeito de esvaziamento do debate democrático do direito à comunicação, na medida em que convence boa parte da sociedade aproveitando-se da cumplicidade política de alguns e da omissão compulsiva de outros - de que quem fala em reformar os marcos regulatórios da comunicação no Brasil para, por exemplo, dar mais transparência às concessões, não permitir a concentração dos meios, em poucos grupos familiares, e estimular conteúdos regionais e nacionais, está atacando a "liberdade de imprensa" ou mesmo atentando contra o direito à livre informação (GENRO apud GUARESCHI, 2013, p. 17).

Na visão do Fórum Nacional pela Democratização da Comunicação (FNDC), em artigo publicado quase um mês antes do início da Conferência Nacional de Comunicação (Confecom), a comunicação na sociedade contemporânea resgata sua função social e ideológica, pois "a percepção de que cinema, jornal, rádio, imprensa, televisão e telefonia são apenas meios de comunicação de massa, perde completamente o sentido", de acordo com o jornalista Rafael Mesquita, que assinou o $\operatorname{artigo}^{2}$ :

Esses meios são mais do que dispositivos de produção, emissão e circulação de mensagens e só uma simplificação muito grande impede de ver que eles foram cada vez mais ganhando formas industriais e, como toda indústria, os seus dispositivos foram incluídos em um sistema e controlados por ele (MESQUITA, 2009).

Esses dispositivos foram pouco a pouco sendo naturalizados na sociedade e passaram a satisfazer os interesses imanentes de quem controla e administra esses meios. "Não podemos nos excluir de entender a forma de seleção e intervenção midiática sobre a sociedade, que prima pela interferência nesse celeiro de construção do material simbólico" (MESQUITA, 2009). Resta saber, indaga o pesquisador, "se os controladores da mídia - que têm ampla capacidade de desenvolver ideologicamente seus interesses - estão balizados pela preocupação em incluir um número maior de pessoas, organizações da sociedade civil, e minorias... numa nova discussão dos mecanismos da comunicação", numa conferência como a Confecom.

Embora a mídia continue impassível e aqueles que a controlam sejam impermeáveis a qualquer discussão ou apelo democratizante, a discussão sobre a liberdade de expressão e de imprensa - presente em praticamente todos os eixos discutidos na conferência - é uma discussão permanente.

\footnotetext{
${ }^{2}$ Artigo de Rafael Mesquita.Uma ferramenta ou ambiente fundamental de intervenção social, 4/12/2009. Disponível em: <http://fndc.org.br/clipping/uma-ferramenta-ou-ambiente-fundamental-de-intervencao-social$\underline{463352 />}$
} 
...é difícil entender e aceitar, apesar das evidências concretas da existência em nossa sociedade, uma mídia caracterizada pela concentração, oligopolização, elitismo, partidarismo explícito e, até mesmo por uma radicalização política, como essa nossa mídia continua, tranquila e impassível, a ditar normas num indiferentismo chocante diante das exigências e dos reclamos de grande número de pessoas conscientes da sociedade civil e das orientações claras da própria Constituição de1988 (GARESCHI, 2013, p. 27).

Nem mesmo a chegada ao Poder de um partido como o PT, que tinha nas suas linhas programáticas a regulação democrática dos meios de comunicação, conseguiu impedir o avanço da concentração da mídia nos últimos 12 anos. A resposta para a pergunta "por que não se avança nas comunicações?" ainda não foi claramente encontrada. Mas a reflexão sobre esse "não avanço" foi feita pelo pesquisador e professor Lima (2013). Embora a resposta não seja dada com todas as letras, Lima reconhece que o Estado, há mais de 10 anos comandado pelo PT, mostrou-se impotente diante da força da "grande mídia":

Por outro lado, apesar de avanços, é inegável que houve até mesmo retrocesso em algumas áreas fundamentais. Em diferentes ocasiões ficaram evidentes a impotência do Estado e as contradições entre forças políticas internas ao próprio Governo, assim como o enorme poder histórico dos oligopólios de mídia. Apesar do reconhecimento tanto do presidente Lula de que "nove ou dez famílias dominam toda a comunicação deste País", como o da presidenta Dilma de que "o Brasil vai ter de regular minimamente, até por que tem casos que, se você não fizer isso, deixa que haja uma concorrência meio desproporcional entre diferentes organismos", não ocorreram ações concretas de mudança. Dessa forma, considerada sua centralidade social, o não avanço nas comunicações dificulta - ou até mesmo impede - o avanço em outros setores, sobretudo na construção de uma opinião pública verdadeiramente republicana e democrática (LIMA in SADER, 2013, p. 224).

Lima (2013) cita também alguns avanços identificados no período, como a criação da EBC e a tentativa de pulverização das verbas publicitárias, a criação do Plano Nacional de Banda Larga e a Conferência Nacional de Comunicação, mas deixa claro que o nó górdio da concentração dos meios não foi enfrentado: "Fica apenas a constatação de que os 10 anos dos governos Lula e Dilma não foram suficientes para alterar o sistema de comunicações oligopolizado e desregulado, dominante há várias décadas no Brasil” (LIMA, 2013, p. 224).

Não basta que "apenas" o Poder Executivo, os movimentos sociais e uma parcela da sociedade queiram enfrentar esse poderio da mídia. Ele nunca vai ser modificado enquanto o Poder Legislativo continuar mantendo em seus quadros representantes - legitimados pelo voto direto - que são proprietários de grande parte das empresas de mídia. 
Segundo dados ${ }^{3}$ divulgados pela Folha, "calcula-se que haja no Brasil pelo menos 271 políticos na condição de sócios ou diretores de 348 emissoras de rádio e TV”. Há que se questionar: é possível esperar alguma mudança no campo da comunicação, que dependa da aprovação do Congresso Nacional que aí está? A resposta já foi dada. Dois anos antes da realização da Confecom, o professor e pesquisador Rebouças (2007) lamentava em artigo ${ }^{4}$ a composição do Congresso Nacional adversa às questões da regulação democrática dos meios:

A abertura do debate das bases legais e das políticas públicas que venham quebrar com o oligopólio dos interesses comerciais em detrimento dos interesses públicos, é fundamental para a construção de uma sociedade democrática. Só que essa abertura esbarra em uma questão quase estrutural. A relação entre parlamentares e grandes corporações de comunicação também são peculiarmente intensas, configurando uma grande força dos políticos-radiodifusores e dos radiodifusores-políticos (REBOUÇAS, 2007, p. 14).

Essa relação, que chega a ser promíscua entre boa parte dos políticos com o sistema midiático, pode ser rompida com a eleição de novos representantes, esperança que no Brasil se renova a cada 4 anos. Todavia, não é bem assim que acontece na prática, basta observar o clã Sarney, no Maranhão, que detém uma concessão de TV e cujos filhos estão quase todos na política. Ou seja, aqueles que possuem a concessão de alguma emissora utilizam-na para se perpetuarem nos cargos e, assim, os herdeiros também utilizam do mesmo expediente para continuar na política.

Em 2010, um ano após a Confecom, o professor Rebouças revelava certo otimismo com relação a essa questão da renovação no Legislativo e na relação deste com a mídia:

É provável que em médio prazo tenhamos uma geração de homens - e mulheres (!) - públicos que não seja mais herdeira daquela anomalia provocada por Sarney e Antônio Carlos Magalhães entre 1985 e 1988, com a distribuição das 1.028 concessões de rádios e TVs. Mesmo na legislatura que está acabando este ano, onde muitos deputados, senadores e governantes ainda são diretamente ligados a empresas de mídia, seria difícil juntar um grande número de políticos-radiodifusores que pensem em uníssono (REBOUÇAS, 2010). ${ }^{5}$

\footnotetext{
${ }^{3}$ Dados da Folha de S. Paulo. Disponíveis em:<http://acervo.folha.com.br/fsp/2009/12/17/2/> .

${ }^{4}$ Evolução da regulamentação da mídia eletrônica no Brasil. Disponível em:<http://www .diarioliberdade.org/brasil/comunicacom/11833-entrevistas-com-edgard-reboucas-a-abrangencia-do-controlesocial.html(5/2/11)>. Acesso em: 19 mar. 2014.

5 Comunicação não deve ser confiada aos donos da mídia. Disponível em: $<$ http://www.observatoriodaimprensa.com.br/news/view/comunicacao_nao_deve_ser_confiada_aos_donos_da_ midia $>$.
} 
Essa declaração foi dada em 2010, em entrevista ao Observatório da Imprensa, quando estava chegando ao final a legislatura que, de certa forma, se envolveu com a realização da Confecom. Outro aspecto que também foi lembrado por Rebouças pode ser considerado para fortalecer a discussão com relação à postura do Legislativo: apesar de muitos políticos serem detentores de concessões de radiodifusão, a maioria não é. O chamado "baixo clero" do Congresso Nacional está fora desse padrão, logo, pode ser sensibilizado para a causa da regulação democrática dos meios de comunicação no Brasil.

Rebouças (2010) argumenta que

O mercado (e a militância pela democratização) supervaloriza a atuação desses personagens. Se observarmos bem, a maioria que resta faz parte do baixíssimo clero. O que precisamos é aproveitar essa próxima leva de parlamentares que entrará em 2011 e fazer um trabalho de esclarecimento quanto à necessidade de um marco regulatório (REBOUÇAS, 2010). ${ }^{6}$

Ainda na busca de elementos para entender por que a sociedade não se sensibiliza pela bandeira da democratização dos meios de comunicação, o professor Rebouças argumenta que essa luta "é uma ação de longo prazo" e a compara com o movimento em defesa do meio ambiente. "Se os ambientalistas estão levando décadas para conscientizar a sociedade sobre suas pautas, qual a nossa previsão para falarmos de democratização das comunicações como se fala de aquecimento global?" (REBOUÇAS, 2010).

Embora a mídia esteja presente na vida de todos, o tempo todo, Rebouças (2010) entende que discutir o assunto é complicado até com estudantes de Comunicação. Ele acha que o assunto ainda está restrito a especialistas da área, à academia e aos fóruns de discussão como o FNDC e o Intervozes:

O problema é que temos dificuldade de tratar desses temas até com nossos estudantes de graduação. É frustrante falar para uma turma sobre o art. 221, o PNBL, a Confecom, o FNDC etc., se ao longo de seus 20, 20 e poucos anos de vida, nunca lhes foi apresentado um exemplar da Constituição. Nem em casa, nem na escola. O que acontece é quase que uma pregação no deserto. A não ser em fóruns como este, não há muito espaço para as propostas vindas desse grupo, mesmo que sejam altamente qualificadas. $\mathrm{O}$ que mais me alegra é que nenhum de nós abandona a tarefa de Sísifo que assumimos, sempre empurrando a pedra até o alto da montanha, mesmo sabendo que ela vai rolar tudo de novo (REBOUÇAS, 2010).

6 Comunicação não deve ser confiada aos donos da mídia. Disponível em: $<$ http://www.observatoriodaimprensa.com.br/news/view/comunicacao_nao_deve_ser_confiada_aos_donos_da_ midia $>$. 
A ideologia invisível dos meios de comunicação é tão eficiente e cumpre tão bem seu papel que é quase impossível discutir o tema da democracia da mídia com o mais interessado: o espectador/leitor/ouvinte/usuário. Segundo Rebouças (2010), "historicamente seu papel foi colocado pelos demais envolvidos como o de mero receptor, ficando muito difícil querer que se posicione ou até se interesse pela questão de um marco regulatório para as comunicações” (REBOUÇAS, 2010).

Segundo esse pesquisador,

Se as pessoas não se manifestam aberta e conscientemente sobre temas tão visíveis como esgoto, educação, saúde, segurança e outras prioridades, por que irão se incomodar com o conteúdo da novela, com a baixaria no programa policialesco, com a concessão do deputado Fulano ou Sicrano, com o padrão japonês, americano ou europeu? É necessária, aqui, uma ação de longo prazo (REBOUÇAS, 2010).

\subsection{Que mídia é essa?}

Encontrar razões que ajudem a entender qual a mídia que se constituiu no Brasil e por que tem tanto poder, e como ainda consegue convencer boa parte da sociedade de que é uma instituição plural e democrática é, com certeza, um desafio. O traço que marca essa mídia, desde a origem, foi determinante no perfil do seu conteúdo. Nossos meios de comunicação são empresas privadas e mesmo o rádio e a televisão, que são concessões do Estado, comportam-se como se fossem independentes do Poder Público, pois sequer são fiscalizados quanto à atuação e aos requisitos que têm de ser cumpridos para a renovação das outorgas.

Para a filósofa e professora Marilena Chauí é um engano achar que as empresas de comunicação têm como proprietários empresários que agem apenas segundo seus interesses e objetivos particulares. "O sujeito do poder não são os proprietários dos meios de comunicação, nem os estados, nem grupos e partidos políticos, mas simplesmente (e gigantescamente) o próprio capital” (KEHL; BUCCI apud CHAUÍ, 2006, p. 74).

Chauí (2006) explica que, nos últimos anos, os investimentos no segmento de mídia e a elevada perspectiva de lucros têm atraído empresários do sistema financeiro, da indústria eletroeletrônica, do setor de armamentos, de telecomunicações, entre outros, que veem no setor a certeza de perpetuação dos seus ganhos. Além disso, em todo o mundo, os grandes conglomerados da mídia estão se fundindo em outros e aumentando ainda mais a concentração da mídia. Em todo o mundo, diz ela, são apenas sete corporações de alcance global. "O poder midiático é um mecanismo de tomada de decisão que permite ao modo de 
produção capitalista, transubstanciado em espetáculo, sua reprodução automática" (CHAUÍ, 2006, p. 74).

Ressalta a filósofa: "não se trata de negligenciar o poder econômico dos senhores dos conglomerados midiáticos nem sua força para produzir ações ou efeitos sociais, políticos e culturais, mas são os proprietários dos meios que são o suporte do capital" (CHAUÍ, 2006, p. 74). Essa condicionante econômica é determinante para o funcionamento da lógica dos meios de comunicação, movidos pela ideologia que perpassa o modo de produção capitalista.

Assim como o poder econômico está ligado aos proprietários das empresas da indústria de comunicação, o poder "ilocalizado" do capital está presente nas representações ou imagens que constituem a ideologia da classe dominante (CHAUÍ, 2006, p. 75). No mundo contemporâneo, todavia, essa ideologia apresenta outros contornos além do apresentado por Marx. "A ideologia hoje é invisível porque não parece construída nem proferida por um agente determinado, ela se converte em um discurso anônimo e impessoal, que parece brotar espontaneamente da sociedade como se fosse o discurso do social" (LEFORT apud CHAUÍ, 2006, p. 75). E acrescenta:

...Para que a ideologia possa ganhar generalidade suficiente e homogeneizar
a sociedade em seu todo é preciso que a mídia cumpra seu papel de veicular
a informação não de um polo em particular, mas de um foco central
circunscrito que se dirige ao todo indeterminado da sociedade... São coisas
do cotidiano, as questões da ciência, da cultura que sustentam a
representação imaginária de uma democracia perfeita, na qual a palavra
circula sem obstáculos (LEFORT apud CHAUÍ, 2006, p. 76).

O poder da comunicação, do ponto de vista da ideologia, não guarda semelhanças com a antiga ideologia burguesa, que tentava impor valores e ideias de modo até primário. Atualmente, a mídia constrói a "ideologia da competência" e convence o usuário de que não é qualquer pessoa ou instituição que tem o direito de falar e de construir uma verdade, pois foi criada a figura do "especialista", que é aquele que está preparado para falar, com conhecimento, sobre a última descoberta da Ciência ou as razões da guerra da Ucrânia. É o sujeito da comunicação que detém o conhecimento e é formador de opinião. É esse sujeito que, cotidianamente, "interioriza a ideologia do capital na sociedade" e faz valer os interesses e princípios da classe dominante, que é a possuidora do discurso da dominação.

Entender como se constituiu a mídia brasileira, como ela tem se modificado e como tem influenciado a sociedade, especialmente após a internet, foi um desafio nesta pesquisa. Para compreender por que a democracia midiática ainda está tão distante da nossa prática 
midiática e por que ainda denominamos os proprietários de empresas de comunicação de "coronéis eletrônicos" é preciso percorrer um caminho de volta na história recente do País.

As raízes que podem explicar qual é, de fato, o DNA dessa mídia, que até hoje não abandonou as práticas patrimonialistas herdadas da nossa colonização portuguesa, que insiste em domar sua audiência, que se recusa a crescer democraticamente, estão arraigadas no modelo de desenvolvimento econômico neoliberal, que estabelece elos de promíscua intimidade entre o Poder, a política e a imprensa, que são dimensões que não podem ser compreendidas isoladamente, conforme Guareschi:

A total ausência de controle da propriedade cruzada dos meios e da formação de redes (de rádio e televisão) deu origem a poderosos oligopólios empresariais multimídia - nacionais, regionais e locais - que exercem seu controle não só sobre a maioria das concessões de radiodifusão como também sobre a mídia impressa (jornais e revistas) e, mais recentemente, sobre os principais provedores de internet (GUARESCHI, 2013, p.14).

A imprensa brasileira emergiu em conjunção com o estabelecimento da Família Real portuguesa, em 1808, e o primeiro jornal brasileiro, que foi o Correio Braziliense, foi editado nesse mesmo ano por José Hipólito da Costa e essa edição só foi possível em Londres, por causa das restrições impostas pela Família Real em relação à publicação e à circulação de jornais no Brasil (MATOS, 2008, p. 29).

Só depois que o Brasil ficou independente, em 1822, é que a imprensa realmente começou a acontecer. Entre 1808 e 1822, a única publicação era o Diário Oficial do Reino que, curiosamente, era chamado de Gazeta do Povo. Segundo Matos (2013), “o jornalismo chegou ao Brasil com 200 anos de deficiência”, já estando em plena expansão em muitos países da Europa e nos Estados Unidos desde os séculos 18 e 19, mas não vamos nos deter aqui nos meandros desse começo de História.

Até o final do século 19, o jornalismo praticado no Brasil era de cunho bastante ideológico e partidário, e as polêmicas que nasciam nos palácios continuavam nos jornais. "A imprensa emergente era vista ainda como uma forma de "tribuna estendida", para usar as palavras de um dos fundadores da República, Benjamim Constant” (MATOS, 2013, p. 30).

O foco foi na imprensa que começou a se consolidar a partir do início do século 20, com mais precisão nos últimos 50 anos. Não poderíamos, naturalmente, saltar para o que aconteceu com a mídia pós-64, que oferece mais elementos para a compreensão da mídia que temos hoje, por isso, faremos um breve relato da mídia do início do século passado, conforme afirma Mattos: 
De acordo com a escassa literatura sobre a mídia naquele período, o jornalismo começou a se definir na virada do século XX. Breguez apud Matos (2000) apontou para três fases do jornalismo impresso brasileiro: a) ideológica ou opinativa (1900-20); b) o estilo informativo e a tendência dos manuais de jornalismo (1920-45); c) o jornalismo interpretativo (1945-80) (MATOS, 2013, p. 30).

Essa última fase, que praticamente se estendeu até o início deste século, foi considerada como "o período do jornalismo moderno, quando técnicas tradicionais, como o lead clássico, foram relaxadas e estilos mais pessoais começaram a aparecer” (MATOS, 2013, p. 30). Para essa autora, apesar de a imprensa ainda continuar partidarizada durante os anos de 1950, o jornalismo brasileiro começou a surgir como um "empreendimento comercial", que tinha como objetivo os interesses empresariais e a obtenção do lucro como prioridade.

...a urbanização e a industrialização do País, somadas à capitalização da elite agroexportadora de café, permitem o desenvolvimento das primeiras empresas jornalísticas. A informação começa a ser vista como um produto, os acontecimentos políticos, econômicos e sociais passam a ocupar o espaço antes preenchido pelo mero debate e os veículos impressos são agora portadores dos interesses da classe produtora e das camadas médias da população. É o fim da imprensa artesanal (MOTTA, 2002, p. 34).

A legislação que foi sendo elaborada ao longe desse período, naturalmente, sofria as influências políticas daqueles que estavam próximos ao Poder. O vínculo entre imprensa e Poder tem na figura de Assis Chateaubriand um exemplar clássico de como era possível sistematizar uma estrutura legal às injunções e práticas políticas. Os empresários da mídia davam os seus primeiros passos e tratavam de se apropriar do que começava a tomar forma na imprensa e mais tarde na radiodifusão. No início da década de 1920, entra em cena a figura de Chateaubriand, que, como Roberto Marinho, a partir dos anos de 1960, detinha influência sobre o Poder e vice-versa, cada um na sua época de "reinado", é claro. "Em 1924, Chateaubriand adquiriu o diário $O$ Jornal, o primeiro daquele que seria o império de comunicação do País" da época (MARTINS; De LUCA, 2011, p.161). Logo de início, Chateaubriand "abandonou o tom simpático à ordem estabelecida, do antigo dono do jornal, e o substituiu pela crítica intransigente de Arthur Bernardes, dando apoio aos movimentos que desafiavam o Governo, como o Tenentismo".

Não é possível pensar que se tratava apenas de um posicionamento meramente político de apoio a essa ou aquela causa política. Chateaubriand já começava a usar o poder do jornal para resolver suas questões pessoais. 
Tratava-se de um ajuste de contas, que remontava ao tempo em que Bernardes frustrou os interesses de uma empresa norte-americana que pretendia explorar os depósitos de ferro em Minas Gerais, estado que então presidia. Os interesses dessas empresas eram defendidos pelo advogado Assis Chateaubriand (MARTINS; De LUCA, 2011, p.161).

Até então, com exceção de poucos periódicos como o Correio da Manhã, de Edmundo Bittencourt, e o Estado de S. Paulo, de Júlio de Mesquita, que se mantinham independentes do Governo, era comum a prática de "compra de opinião", como mostra o trecho a seguir:

\begin{abstract}
A importância do surgimento de um jornal como o Correio da Manhã ganha novos sentidos quando se tem em conta que os aplausos da imprensa eram assegurados pelo Tesouro Nacional, consolidando tendência que, na feliz síntese de Nelson Werneck Sodré, tornava mais fácil comprar um jornal do que fundar outro e ainda mais prático comprar a opinião do que adquirir o próprio jornal, como demonstrou Campos Sales (presidente entre 1898 e 1902) (MARTINS; De LUCA, 2011, p. 164).
\end{abstract}

Campos Sales advoga tal expediente justificando que havia herdado a prática do expresidente Floriano Peixoto. Medeiros de Albuquerque (apud MARTINS; De LUCA, 2011) afirma com veemência a postura adotada pelo então presidente:

Campos Sales perverteu também a imprensa. Foi, de fato, ele quem começou a corrupção em larga escala. Sem dúvida, ninguém poderá dizer que a ele cabe a invenção das subvenções à imprensa. Isso sempre se fez, mais ou menos. Mas no tempo de Prudente de Morais (governou de 1894 a 1898 e foi o primeiro presidente civil) o caso estava restrito à inserção de editais e de outras publicações claramente tidas como do expediente normal das repartições. O que havia é que elas eram dadas aos jornais amigos e negadas aos outros. Campos Sales saiu desse regime relativamente honesto e começou a subvencionar os jornais que o defendiam. E que subvenções! Ele confessou ter gasto quatro mil contos de réis, mas na verdade gastou mais de sete mil. De ano para ano as verbas cresciam, porque a oposição popular contra o Governo também foi crescendo em proporções formidáveis (MARTINS; De LUCA, 2011, p. 174).

Esse registro é importante para ilustrar como se davam as relações entre o Poder e a imprensa, ainda nos seus primórdios. Essa prática, com a transformação da imprensa em "um negócio de mercado" acabou tomando a forma de vultosos e direcionados anúncios publicitários. A opinião dos jornais não era, certamente, mantida favorável ao Governo apenas por meio dessas estratégias comerciais. 
No início do século passado, sempre que era necessário, o Governo fazia valer a força e criava leis que dificultavam a atividade da imprensa, de acordo com Martins e De Luca (2011):

Ao lado da grande capacidade de persuasão dos favores governamentais, não
raros essenciais para a saúde financeira de uma imprensa-empresa que
enfrentava, do ponto de vista comercial, limites estruturais para a sua
sustentação, não se hesitava em recorrer, sempre que se julgasse necessário,
a controles de natureza diversa, que incluíam arbitrariedades e medidas de
força, ademais de restrições de caráter legal (MARTINS; De LUCA, 2011,
p. 165).

Nesse caso, as autoras se referem a uma lei denominada Lei Adolfo Gordo, em alusão ao senador paulista que foi autor do projeto. O País encontrava-se em estado de sítio e em outubro de 1923 a lei foi baixada e determinava um tipo de limitação à expressão. A lei estabelecia a responsabilidade penal sucessiva do autor, do editor e até do distribuidor do jornal, para o que era considerado como abuso de imprensa.

Mais tarde, já na década de 1930, quando teve início o movimento que levou Getúlio Vargas ao Poder, a disputa entre os jornais mais importantes da época começaram a se dar entre os que apoiavam e os que se opunham ao presidente instituído. Vargas chegou ao Poder, pela primeira vez, em 1930, quando liderou a revolução que colocou fim à chamada "República Velha" e com a sua posse impediu que Júlio Prestes, que havia sido eleito, tomasse posse.

Vargas governou em três períodos distintos, sendo que de 1937 a 1945 impôs ao País um regime ditatorial com graves consequências para as liberdades tanto de imprensa como de expressão. No início do seu governo, ainda antes do Golpe de 1937,

...os proprietários das empresas jornalísticas, ainda que apoiando as medidas do Governo, eram vigiados de perto... Exasperava-se o clima de tensão e uma ameaça iminente parecia rondar a Nação e pouco tempo depois justificaria o golpe de novembro de 1935, que instalou o Estado Novo (MARTINS; De LUCA, 2011, p. 170).

O novo regime não se limitou a repetir práticas anteriores de suborno, empastelamento de jornais ou violência de toda ordem. O ditador Vargas criou um órgão específico destinado à propaganda e ao controle da informação, o temível e inesquecível Departamento de Imprensa e Propaganda (DIP). O órgão se instalou nas dependências do Palácio Tiradentes, que havia sido sede da Câmara dos Deputados, e criou um grande aparato de controle e censura à imprensa, bem como sobre as artes e espetáculos em geral. O DIP criou o programa 
oficial Hora do Brasil, ouvido em todos os lugares do País, e ainda hoje apresentado ${ }^{7}$. O DIP também criou uma série de documentários que faziam propaganda das ações do Governo e que tinham de ser, obrigatoriamente, exibidos antes das sessões de cinema.

Para enfrentar as empresas de mídia, Getúlio determinava que o DIP padronizasse o que ele queria que fosse divulgado e enviava para todos os jornais, tentando monopolizar a disseminação de notícias. Ele usava a propaganda como instrumento ideológico para convencer a sociedade sobre a legitimidade do seu Governo. Além de perseguir e censurar aqueles que o regime acusava de ser comunista, o DIP exercia a censura à imprensa e determinava quais palavras e termos podiam ser usados ou não. Além disso, o DIP exorbitava suas funções, como aconteceu quando invadiu e expropriou o jornal O Estado de S. Paulo:

O Governo Vargas, além de lançar seus próprios jornais e revistas, valeu-se da força: expropriou $O$ Estado de S. Paulo, a partir de março de 1940, e o manteve sob intervenção até 1945, e no Rio de Janeiro encampou A Noite e a Rádio Nacional (MARTINS; De LUCA, 2011, p.172).

A censura e a existência de um órgão como o DIP marcaram de tal forma a história do País que essa memória ainda alimenta aqueles que temem a volta da censura aos meios de comunicação "travestida de controle social”. De certa forma, essa lembrança da ação do DIP acabou por cristalizar uma formação discursiva que ficou incrustada, para o bem ou para o mal, na memória daqueles que temem a volta da censura ou usam esse argumento para se posicionarem contrários a qualquer discussão sobre a regulação da mídia. Isso ficou claro durante a cobertura da Confecom. Tanto os representantes da mídia tradicional como os sites que cobriram o encontro acionaram alguns elementos que fazem parte da história recente do País e que têm a ver com questões relacionadas à regulamentação da comunicação.

Mais tarde, depois de o ex-ditador voltar "nos braços do povo" ao Poder, não podia mais contar com a simpatia da imprensa, em face de toda a censura e perseguição perpetrada pelo DIP, conforme o texto a seguir:

Ao iniciar sua volta ao Poder, em 1951, Vargas não contou com o apoio da imprensa escrita e falada de maior circulação no País. Sua campanha política foi feita com a utilização de caminhões equipados com alto-falantes e de volantes impressos que divulgavam seu programa de Governo. A imprensa, na verdade, atacou violentamente as propostas políticas, econômicas e sociais do candidato Vargas. Essa recusa em apoiar a volta de Vargas estava referenciada principalmente ao período do Estado Novo, quando se criou uma imagem negativa do ditador entre intelectuais e jornalistas. Estes últimos se lembravam de que a Constituição de 1937 abolira a liberdade de

\footnotetext{
${ }^{7}$ Hoje a "Hora do Brasil" é chamada de a "Voz do Brasil".
} 
expressão do pensamento e que todos os meios de comunicação foram então submetidos à censura. ${ }^{8}$

Getúlio Vargas teve um novo Governo extremamente difícil e sabia que não podia mais usar as armas e estratagemas de outrora. "Os antagonismos políticos tornaram-se agudos e refletiam-se claramente na imprensa. Vargas não tinha condições para subornar a grande imprensa, como se fizera antes no Brasil e que Campos Sales confessara com tanta simplicidade", lembra Sodré (1999, p. 398). De acordo com esse autor, sem a via do autoritarismo só lhe restava a via do mercado, da negociata, pois

Vargas julgou que esse caminho, largamente batido, lhe permitiria ter pelo menos um órgão oficioso, de base popular, capaz de permitir-lhe enfrentar a maciça frente dos jornais controlados pelas agências estrangeiras de publicidade. Foi assim que vultosos e rápidos créditos possibilitaram, em 1951, a Samuel Wainer, fundar o vespertino Última Hora, que logo conquistou lugar de destaque na imprensa carioca e brasileira (SODRÉ, 1999, p. 399).

Sem o apoio dos jornais mais influentes da época e sem usar os costumeiros métodos da Ditadura, Vargas, depois da aproximação com o jornalista Samuel Wainer, apoiou o jornalista para que este fundasse seu próprio periódico, abandonando o conglomerado de Chateaubriand. Assim, conseguiu de volta o apoio de um grande jornal. Foi assim que nasceu o Última Hora, marcante na história do jornalismo brasileiro.

Em oposição a Getúlio Vargas, além da ferrenha postura do jornalista Carlos Lacerda, proprietário do jornal Tribuna da Imprensa, estavam também os Diários Associados e a incipiente Rede Tupi, ambos de Assis Chateaubriand, e também, é claro, a Rádio Globo. Depois do que a imprensa sofreu durante o Estado Novo, só mesmo "comprando" literalmente um jornal ou fundando um novo (como acabou fazendo) é que Getúlio conseguiu, de volta, a "simpatia" de um jornal da grande imprensa da época.

Mas pouco antes da sua derrocada, conforme Sodré:

Vargas suportou terrível campanha da imprensa, comandada por Assis Chateaubriand, nos Diários Associados, para pagar energia à Light (empresa americana que queria impedir que o Governo criasse uma usina própria de energia e continuasse dependendo da gerada pela Light), que financiou a campanha vitoriosa junto à imprensa e acabou estagnando a eletrificação do País (SODRÉ, 1999, p. 400).

\footnotetext{
${ }^{8}$ Getúlio Vargas e a imprensa: uma relação conflituosa. Disponível em: <http://cpdoc.fgv.br/producao/ dossies/AeraVargas2/artigos/EleVoltou/RelacaoImprensa>.
} 
O nacionalismo, que antes era uma qualidade do novo getulismo, passou a ser criticado pela grande imprensa "mobilizada pelas agências norte-americanas" que centraram seu ataque nessa área. O Clube Militar, que apoiava Getúlio, tentou resistir, mas tinha apenas o apoio do jornal de Samuel Wainer, que era governista, e acabou sucumbindo e perdendo o apoio de Vargas. Apesar dos esforços do Governo "e das concessões feitas ao imperialismo" (SODRÉ, 1999, p. 401), Vargas assistiu aos ataques da imprensa contra o "seu" jornal, como mostra o texto:

Toda a imprensa concentrou-se, então, em demonstrar o óbvio: que esse jornal (Última Hora) só se tornara possível pela concessão de grandes empréstimos nos estabelecimentos oficiais de crédito. Foi a 'operação' que ocupou a grande imprensa em 1953 e que se arrastaria por alguns meses: era necessário pôr a descoberto os empréstimos levantados pelo vespertino oficioso, esquecendo aqueles levantados nas mesmas condições, ou piores, pelos outros jornais (SODRÉ, 1999, p. 401).

Sodré (1999) faz longa referência aos empréstimos obtidos pelo jornal $O$ Globo, no Banco do Brasil, entre 1950 e 1952, que eram bem superiores aos obtidos por Samuel Wainer. Enquanto publicamente o grupo de Marinho atacava o governo de Vargas também se beneficiava das benesses do banco estatal, conforme o texto a seguir:

Enquanto levantava, em dois anos, no Banco do Brasil, empréstimos correspondentes a mais de um milhão de dólares, $O$ Globo combatia ferozmente 'os favoritismos do Banco do Brasil' participando ativamente da campanha contra os empréstimos feitos ao Última Hora e formando a vanguarda da 'Aliança Popular Contra o Roubo e o Golpe' que se propunha a combater a 'corrupção do Governo' (SODRÉ, 1999, p. 402).

Esse episódio rico em detalhes, contado por Sodré (1999), dá uma dimensão do DNA de um dos maiores jornais brasileiros e deixa claro que essa forma de conduta explica, e muito, a relação promíscua entre imprensa e Poder que se estabeleceu no País há mais de 60 anos.

Na década de 1950, o Diário da Manhã, na coluna do jornalista Rafael Correia de Oliveira, na tentativa de reagir, denunciou que os Diários Associados também obtinham privilégios até maiores do que os de Wainer, mas era tarde demais. "O fato é que a campanha penetrou fundo no espírito dos leitores, mobilizou a opinião pública, abalou o Governo" (SODRÉ, 1999, p. 402). No fundo, o que a grande imprensa queria não era destruir apenas o jornal do apadrinhado de Vargas, mas usá-lo como pretexto para atacar o Governo e enfraquecê-lo, uma vez que "empresas jornalísticas continuavam a receber favores, concessões e facilidades para desenvolver monopólios". "Embora pareça contraditório, as 
empresas, de fato, estavam defendendo interesses das agências americanas e Vargas, mais uma vez, foi omisso" (SODRÉ, 1999, p. 403).

Para concluir este breve histórico das relações entre mídia e Poder, na década de 1950, não seria adequado deixar de fora outro exemplo de favorecimento obtido por outra empresa jornalística, de grande porte, para mostrar que não era só o jornal $O$ Globo que agia de forma oportunista. Em meio à crise que Vargas enfrentava, seu então ministro das Relações Exteriores, Vicente Rao, ligado a Júlio de Mesquita Filho, pressionou o presidente para que ele "transferisse ao jornal $O$ Estado de $S$. Paulo a concessão da Rádio Eldorado que, uma vez montada, aliou-se à Rádio Globo na propaganda do golpe” (SODRÉ, 1999, p. 403).

Logo em seguida ao ano de criação da Petrobras, em agosto de 1954, a crise contra Getúlio atingiu seu clímax e, segundo Sodré, o suicídio foi a única forma encontrada por Getúlio "para escapar à desmoralização a que vinha sendo submetido". Para Sodré (1999), a comoção diante da tragédia e o "libelo contido na carta de despedida de Getúlio representaram um alarme profundo ante a situação do País cujos destinos o imperialismo tentava conduzir" (Idem, p. 407). Essa circunstância inesperada que abalou a opinião pública e frustrou o Golpe de Estado que estava a caminho garantiu a posse de Juscelino Kubitschek.

A campanha da imprensa - subsidiada pelas grandes corporações americanas - contra o monopólio do petróleo (quando da criação da Petrobras em 1953) reforça a questão da "influência e grande controle que as agências de publicidade exerciam sobre os meios de comunicação e o pensamento em nosso país” (SODRÉ, 1999, p. 405), quando foi preciso constituir uma Comissão Parlamentar de Inquérito (CPI), em 1957, “onde ficou comprovada a ligação íntima e casual entre aquelas agências americanas, a serviço dos trustes internacionais, e a campanha da imprensa brasileira contra a criação da Petrobras em 1953” (Idem, p. 407).

Em face da influência que as empresas estrangeiras exerciam sobre a imprensa brasileira da época, Sodré faz alusão a um tema - também vital nesta pesquisa - que é o da liberdade de imprensa, e lembra, apropriadamente, "que o esforço das campanhas pela liberdade de expressão, que surgem periodicamente (...), visa sempre e tão somente a não exclusão do poder governamental, a interferência do setor público. O obstáculo à liberdade de imprensa é, sempre, o Estado, por meio da censura. Trata-se, evidentemente, de concepção liberal, peculiar à fase ascensional da burguesia” (SODRÉ, 1999, p. 409).

A percepção de Sodré, que se coaduna com a realidade atual do Brasil, é que ao capitalismo de então interessava, certamente, uma imprensa absolutamente livre de quaisquer controles, para que pudesse servir aos interesses monopolistas e imperialistas, ficando "a censura vinda do Governo como um aspecto menor". No capitalismo, "a imprensa se 
transformou de instrumento de esclarecimento em instrumento de alienação, fugindo inteiramente aos seus fins originários" (SODRÉ, 1999, p. 409).

O início da década de 1960, com destaque para a tentativa de antecipação do Golpe de 1964 que ocorreu em agosto de 1961, quando os militares queriam impedir a posse de João Goulart, foi marcada pela postura de uma imprensa que "não cedeu à pressão dos detentores da autoridade militar", pois essa resistência durou pouco tempo. Para Sodré (1999), "tratavase de mero ensaio para o Golpe de 1964, vencido em 1961. O movimento antinacional e antidemocrático retraiu-se, organizou-se e preparou, longa e meticulosamente, a investida que permitiria a vitória" (Idem, p. 409).

Quando os grandes jornais começaram a publicar editoriais (citados aqui) contra o governo de Jango, "toda a grande imprensa articulada, em coro, participou dessa preparação psicológica como o rádio e a televisão", ficando claro que os organizadores do Golpe Militar deflagraram sua campanha pela necessidade da intervenção militar. "Foi a última 'operação' montada pela imprensa empresarial em nosso país" (SODRÉ, 1999, p. 410).

Junto com esses acontecimentos políticos que quase impediram a posse de João Goulart, vale lembrar que estava em curso a criação do Código Brasileiro de Telecomunicações (CBT), com consequências para o atual sistema de mídia no País. O modelo de gestão da radiodifusão cuja gênese se deu em meio à conturbada situação política que o País vivia, até hoje não foi revertido e preserva os mesmos vícios do seu começo. Esse período atribulado resultou no que hoje é sentido por toda a sociedade e, mais do que isso:

Durante a década de 1960, constituiu-se uma coligação ligada à radiodifusão comercial cujo objetivo era pressionar o Governo e garantir seus interesses econômicos, visto que a taxa de crescimento desse novo e empreendedor mercado começava a demonstrar índices de estagnação. A presença de empresários desse setor no Congresso Nacional permitiu um aumento significativo no poder de pressão do grupo em questão, que, legislando em causa própria, tornou-se capaz de anular a maioria das restrições aos seus próprios interesses políticos e econômicos. Essa simbiose entre Poder Público e privado constituiu um obstáculo ao Executivo, uma vez que qualquer decisão governamental que prejudicasse o empresariado da radiodifusão seria repudiada pelo Legislativo. Os vetos de Jango ao Código Brasileiro de Telecomunicações, portanto, representaram sua tentativa em minar a força desse setor empresarial cuja representação política deu-lhe acesso a irrestritos privilégios, além de grande influência na opinião pública, por intermédio dos meios de comunicação. O resultado desse choque demonstrou a grande organização do grupo da radiodifusão, pois, apesar de sua descentralização regional, este era coeso na medida em que possuía um interesse coletivo único, que o tornava forte o bastante para rivalizar e 
superar a influência política de Jango no Congresso Nacional (MUNTEAL apud LIMA, 2012). ${ }^{9}$

A origem de toda a desorganização nas concessões e outorgas de rádio e TV coincidiu com o surgimento dos veículos de comunicação eletrônica, ou seja, foi um começo ruim que desandou todo o restante da história. "Apoiada numa legislação cheia de brechas, a farra das concessões assumiu faces diferentes ao longo das últimas décadas, respeitando, porém, o mesmo critério desde os anos de 1950 - a supremacia de interesses privados de empresas e de políticos" (Intervozes) ${ }^{10}$. Após o fim do regime militar, o caráter mercantil e monopolista da imprensa brasileira se fortaleceu.

O uso das concessões como moeda de troca não foi frequente apenas durante o regime militar, pelo contrário. De acordo com o Intervozes, durante o governo Figueiredo (19791985) foram concedidos 634 canais de radiodifusão, 295 de rádios AM, 299 de rádios FM e 40 de emissoras de TV. Porém, o primeiro presidente civil, José Sarney, eleito indiretamente, manteve essa prática e exorbitou dos seus direitos. Na ocasião da votação da Constituição de 1988, o então ministro das Comunicações, Antônio Carlos Magalhães, que pretendia “moralizar" a farra de concessões de Figueiredo, desistiu da ideia e, com pressões da Abert, “deu início a uma das maiores distribuições de outorgas a políticos da história brasileira. Com a instalação da Constituinte, a partir de 1987, Sarney e ACM encontraram nas concessões uma maneira de agradar seus aliados políticos e utilizaram-nas para troca de favores". ${ }^{11}$

\section{2 "Abatalha invisível da Constituinte"}

De certa forma, o encontro de ideias e posições - verificado durante a Confecom também ocorreu, de forma espaçada no tempo, no período em que deputados e senadores se reuniram, em 1987 e 1988, em Assembleia Nacional Constituinte para, juntos, escrever a nova Constituição do País, promulgada em outubro de 1988, que ainda está em vigor. Há aproximadamente 26 anos, quando o Capítulo V da Comunicação Social foi escrito, representantes do segmento privado da mídia, juntamente com representantes das entidades sociais, mais especificamente, a Fenaj, sindicatos e a emergente Frente Nacional de Luta por Políticas Democráticas de Comunicação (que depois se tornou o FNDC), que havia sido

\footnotetext{
${ }^{9}$ A caminho da ditadura. Disponível em: 〈http://www.observatoriodaimprensa.com.br/news/imprimir/50310>. Acesso em: 30 out. 2012.

${ }^{10}$ Concessões de rádio e TV. Onde a democracia não chegou. Disponível em:<http://www.intervozes.org.br/arquivos/interrev001crtodnc>. Acesso em: 3 mar. 2014.

${ }^{11}$ Concessões de rádio e TV. Onde a democracia não chegou. Disponível em:

<http://www.intervozes.org.br/arquivos/interrev001crtodnc >. Acesso em: 3 mar. 2014.
} 
criada em julho de 1984, e também a Conferência Nacional dos Bispos do Brasil (CNBB), reuniram-se, com a mediação de deputados constituintes, para discutir as bases para a Comunicação no País.

Pouco mais de 20 anos depois, em 2009, alguns desses mesmos atores reuniram-se para discutir o mesmo assunto, mas com um novo ingrediente - a tecnologia. Naturalmente, no cenário da Conferência, parte das pessoas presentes era a mesma de 20 anos atrás, e essas pessoas mudaram ao longo do tempo, mas a sua representatividade aproxima-se daquela verificada em 1988. A diferença é que, naquela época, havia a presença maciça de parlamentares envolvidos com o tema, uma vez que se tratava da criação de leis, enquanto em 2009, a presença mais verificada foi a dos movimentos sociais.

Outra diferença importante é que, no encontro de 2009 esperava-se que os artigos aprovados pela Constituição saíssem do papel, provocassem mudanças e fossem, de fato, regulados e colocados em prática, como o caso dos arts. 220, 221, 223 e 224. Em 1988, estes estavam sendo elaborados e exigiram um trabalho hercúleo da Comissão Temática e da Comissão de Sistematização.

São ambientes e circunstâncias absolutamente distintos, mas é possível comparar e traçar um paralelo - que é o que se pretende neste momento - entre os discursos observados na época da Constituinte e os manifestados na Conferência Nacional de Comunicação. Em ambas as situações, havia um pesado jogo de interesses e a intenção, das duas partes, era não perder espaço diante de possíveis decisões acerca da regulação da mídia que o País precisava definir.

A ideia era trazer à Conferência as vozes que reverberaram em 1987/88, pela democratização dos meios, assim como identificar outras que, desde então, posicionavam-se contrárias. Além disso, era preciso observar comportamentos em um cenário mais livre e informal, como uma conferência nacional, depois de pouco mais de 20 anos. Por isso, foi fundamental pesquisar os jornais da época, além de consultas como a tese de mestrado de Motter (1994), cuja dissertação foi apresentada ao Departamento de Ciência Política e Relações Internacionais da Universidade de Brasília (UnB).

Com o título A batalha invisível da Constituinte - Interesses Privados versus caráter público da radiodifusão no Brasil, Motter (1994) discutiu "a relação privatista que os grupos políticos dominantes do setor midiático estabeleceram com o Estado", com destaque para a disputa de interesses, na Constituinte, “entre os principais atores que representavam os grupos políticos e econômicos privilegiados pelo modelo clientelista de concessões e os grupos sociais alijados por essa mesma política e sem acesso à mídia” (MOTTER, 1994, XI). 
Uma decisão tomada logo no início dos trabalhos da Constituinte abriu espaço para maior participação da sociedade civil na elaboração da nova Carta. A Comissão Mista encarregada de dar um parecer sobre a Proposta de Emenda Constitucional (PEC), que convocava a Constituinte, composta por 11 deputados e 11 senadores, pleiteava que fosse eleito um Congresso exclusivo para elaborar a nova Constituição, o que não foi adiante, para desapontamento da sociedade civil. Essa derrota, porém, fez com que as entidades e movimentos sociais que estavam em campanha pela Constituinte exclusiva, "engajassem em torno de uma nova tarefa: a de garantir ampla participação da sociedade civil no processo de elaboração da nova Constituição" (MOTTER, 1998, p. 34).

Até então, os representantes da sociedade civil não queriam que a forma congressual para a elaboração da Constituição fosse a escolhida, "pois isso implicaria na presença ostensiva de significativo número de parlamentares proprietários de emissoras de rádio e televisão, constituindo-se num poderoso "grupo de interesse" que oporia enorme resistência às propostas de mudanças na área da Comunicação” (MOTTER, 1994, p. 65). Apesar disso, “as organizações e movimentos populares destacaram-se nesse período preparatório da Constituinte, desenvolvendo atividades educativas que visavam divulgar informações sobre o processo, destacando sua importância para o País” (Idem, p. 84).

Por ter demorado muito o início do processo, quase 2 anos desde a convocação até o começo dos trabalhos, o movimento social pró-participação popular teve mais tempo para se fortalecer e obter mais adesões das organizações da sociedade civil. "A iniciativa embrionária, que iniciou essa ampla mobilização social, partiu do Plenário Pró-Participação Popular na Constituinte, criado em São Paulo, em fevereiro de 1985, que tinha como principal objetivo garantir a participação popular no processo constituinte" (MOTTER, 1998, p. 85). Em maio de 1986, já havia comitês e comissões organizados em 18 estados. Esse movimento tinha importantes apoios como o da Ordem dos Advogados do Brasil (OAB), Conferência Nacional dos Bispos do Brasil (CNBB), sindicatos, associações civis, universidades, além de profissionais liberais, jornalistas, professores e estudantes.

Finalmente, quando os trabalhos da Assembleia Nacional Constituinte começaram, depois de mais de dois meses sobre a discussão do regimento interno, ficou garantida a participação popular na elaboração da nova Carta. Entre os três instrumentos aprovados: apresentação de emendas populares, apresentação de sugestões, e a realização de audiências públicas; esta última foi a que mais abriu espaço para que o movimento pela democratização dos meios pudesse colocar as suas posições e enfrentar as pressões das entidades representativas dos empresários radiodifusores. 
Ao adotar essa iniciativa (das audiências públicas) a Constituinte criou um espaço privilegiado para ouvir a sociedade civil. Nessas audiências seriam tomados os depoimentos de personalidades e representantes dos segmentos organizados... Elas constituíram, certamente, um dos momentos mais ricos e efervescentes do processo constituinte, oportunizando um amplo debate em torno do temário respectivo de cada subcomissão, com espaço para a manifestação de diferentes correntes de opinião (MOTTER, 1998, p. 96).

Segundo Motter (1998), foram mais de 800 depoimentos e documentos colhidos durante a fase das audiências públicas.

Durante o período militar, as forças mais representativas da sociedade civil uniram-se aos empresários de mídia numa luta comum, que era o fim da censura e o restabelecimento da liberdade de expressão. Com o fim da ditadura, outras questões ganharam espaço, como a concentração do controle da mídia na mão de poucos grupos econômicos.

O processo da transição do regime autoritário para a democracia no Brasil colocou em evidência a questão da concentração dos meios de comunicação de massa no País. A partir dessa constatação, incluiu-se na agenda política a necessidade imperiosa e inadiável da democratização da comunicação, sobretudo dos mídia eletrônicos (MOTTER, 1994, p. 137).

Libertar os meios de comunicação de massa do jugo da censura foi durante o período da abertura a reivindicação que unificava essa luta. Mas o tema da democratização da comunicação foi pautado também pelos desvios da política de concessão e de serviços de radiodifusão e, sobretudo, pela ocorrência de conflitos entre a vontade manifesta da opinião pública e a posição assumida pelos mídia. Essa falta de sintonia ficou evidenciada em episódios como o da campanha pelo restabelecimento da eleição direta para presidente da República, em 1984, quando a TV Globo se negou a noticiar nos seus telejornais as manifestações de massa que se sucediam nas principais cidades do País (MOTTER, 1994, p. 137).

Para Motter (1994), ficou claro que a luta contra a Ditadura e em defesa das liberdades democráticas "despertou os segmentos mais politizados da sociedade para a importância da mídia e dos processos de comunicação de massa nas sociedades modernas” (Idem, p. 137). Ou seja, ficou evidenciado que a democracia do País teria que passar pela democracia da mídia, com a revisão do controle dos meios por monopólios privados. Esse despertar, com o apoio da Igreja, sindicatos, organizações populares e universidades, contribuiu para o surgimento de um movimento pela democracia da mídia, que se consubstanciou numa Frente Nacional "na luta em defesa de propostas antimonopolistas e democratizantes para a área de comunicação" (MOTTER, 1994, p. 137). 
É importante registrar o histórico dessa frente, feito com precisão, por Motter, para explicar a origem do Fórum Nacional pela Defesa da Democratização da Comunicação (FNDC), que teve como ponto de partida exatamente essa frente criada em 1984. Esse processo surgiu como iniciativa dos sindicatos de jornalistas, da Fenaj e de outras entidades ligadas ao tema. Ainda em 1980, o curso de Comunicação Social da Universidade Federal de Santa Catarina (UFSC) fez a primeira tentativa de uma proposta ampla pela democracia dos meios, que foi apresentada, naquele mesmo ano, no IV Encontro Nacional de Estudantes de Comunicação (Eneco) realizado em Curitiba (PR). Três anos depois, o tema voltou com mais força, com a realização simultânea de dois eventos na área: o VI Encontro Latino-Americano de Faculdades de Comunicação Social e o VII Congresso da Associação Brasileira de Ensino e Pesquisa da Comunicação (Abepec) realizada em Santa Catarina. O tema foi a implicação das políticas de comunicação para a democracia dos meios e o evento reuniu, pela primeira vez, uma representação expressiva das entidades diretamente interessadas no assunto, entre elas a Fenaj, representada por Audálio Dantas, seu presidente. ${ }^{12}$

Esses encontros produziram um documento final que:

Apontava como tarefa imediata a articulação de uma frente nacional (...). Depois de sucessivos adiamentos, provocados por carência de recursos para organizar a nova reunião, a Frente Nacional de Luta por Políticas Democráticas de Comunicação foi criada no dia 4 de julho de 1984, com a divulgação de um documento-manifesto assinado inicialmente por seis entidades: Fenaj, Associação Brasileira de Imprensa (ABI), Federação das Associações de Moradores do Rio de Janeiro, Associação Brasileira de Ensino e Pesquisa da Comunicação (Abepec), Centro de Estudos de Comunicação e Cultura de Brasília ${ }^{13}$ e o Departamento de Comunicação da Universidade Federal de Santa Catarina. No dia 24 de setembro de 1984 ocorreu o lançamento da Frente, já com a adesão de 24 entidades e 18 parlamentares. No ano seguinte a Frente chegou a reunir 45 entidades e 24 parlamentares (MOTTER, p. 140).

Com a derrota da Emenda Dante de Oliveira e do movimento pelas "Diretas Já", a sociedade civil organizada sofreu um baque e atravessou "um período de desmobilização que provocou um refluxo muito grande no movimento pró-democratização da comunicação" (Idem, p. 140). Só em fevereiro de 1987, com a expectativa do processo constituinte, essa situação começou a mudar. A Fenaj, sob a presidência do jornalista de Brasília, Armando

\footnotetext{
${ }^{12}$ AudálioDantas, ex-deputado do então MDB, foi um importante jornalista na luta pela democratização do País estando à frente do Sindicato dos Jornalistas Profissionais de São Paulo, na época da prisão e morte de Vladimir Herzog e depois eleito presidente da Fenaj em 1983.

${ }^{13} \mathrm{O}$ Centro de Estudos de Comunicação e Cultura (CEC-1984) foi uma iniciativa inédita dos professores de Comunicação da UnB e tinha por objetivo realizar pesquisas e prestar serviços na área de Comunicação e Cultura.
} 
Rollemberg, assumiu o compromisso de rearticular a Frente, para enfrentar os embates que, certamente, aconteceriam na Assembleia Nacional Constituinte.

Pouco antes, em abril de 1986, a Fenaj e o Sindicato dos Jornalistas do Distrito Federal promoveram, em Brasília, o Encontro Nacional dos Jornalistas sobre A Comunicação na Constituinte, que deflagrou o processo de discussão na categoria das propostas específicas que seriam levadas à Constituinte ${ }^{14}$. Segundo o trabalho de Motter (1994), esse encontro foi crucial para o processo que se seguiu depois.

Ao final do encontro, que teve a participação de 140 delegados, representando 25 sindicatos da categoria de todo o País, foi divulgado um documento final, denominado "Carta de Brasília" 15 , que serviu para desencadear a disputa da comunicação com os setores empresariais, que teria sua principal batalha na Constituinte (MOTTER, 1994, p. 142).

É pertinente destacar que na Carta de Brasília, de 1986, a categoria empunhava a mesma bandeira, contra o fim do diploma para o exercício da profissão de jornalista, cujo intento foi conseguido em 17 de junho de 2009, 23 anos depois, com decisão do Supremo Tribunal Federal. ${ }^{16}$

O documento (Carta de Brasília) repudia a campanha pelo fim do diploma, liderada pelos grandes jornais do País, e mereceu acolhida no anteprojeto de Constituição elaborado pela Comissão Afonso Arinos. Os grandes jornais, por sua vez, dedicaram surpreendente cobertura ao evento, questionando o apoio institucional obtido pela Fenaj e pelo Sindicato dos Jornalistas do Distrito Federal para promovê-lo (Idem, p. 144).

As reações da mídia tradicional fortaleciam ainda mais o plano de ação em curso para o embate nas conversações sobre o modelo de comunicação para o País. Como a frente ainda não tinha se articulado plenamente, coube à Fenaj a apresentação da proposta de texto constitucional aprovada pelos jornalistas no congresso, em fevereiro de 1987. Essa proposta também recebeu apoio no XXI Congresso Nacional dos Jornalistas, realizado em São Paulo em novembro de 1986, com a elaboração da Carta de São Paulo, que apoia integralmente as

\footnotetext{
${ }^{14}$ Os debates seguiram o roteiro sugerido pelo documento A Comunicação na Constituinte, preparado pelo Sindicato dos Jornalistas do Distrito Federal, segundo matéria publicada pelo Correio Braziliense em 17/4/86, p. 21, com o título: Documento propõe Conselho (MOTTER, 1994, p. 142).

${ }^{15}$ A Carta de Brasília defende, entre outras coisas, um novo modelo de comunicação social para o País e sugere a criação do Conselho Nacional de Comunicação e uma legislação para impedir o monopólio na radiodifusão.

${ }^{16}$ Supremo decide que é inconstitucional a exigência de diploma para o exercício do jornalismo. Disponível em: $<$ http://www.stf.jus.br/portal/cms/verNoticiaDetalhe.asp?idConteudo=109717>.
} 
propostas formuladas em Brasília, reiterando que "a democratização da comunicação é indispensável para a conquista de uma verdadeira democracia” (MOTTER, 1994, p. 145).

\subsubsection{Abert}

A união e a organização dos empresários do segmento privado de mídia aconteceram bem antes do que se observou com as entidades ligadas ao movimento pela democracia dos meios. A organização aconteceu oficialmente no início da década de 1960, de forma coesa e pragmática. Como se sabe, a Associação Brasileira de Emissoras de Rádio e Televisão (Abert) foi fundada no mesmo dia em que o Congresso Nacional conseguiu derrubar os 52 vetos que o então presidente João Goulart havia imposto ao Código Brasileiro de Telecomunicações (Lei $\left.n^{\circ} 4.117 / 62\right)$.

Esse fato ficou emblemático para o segmento e consolidou o ideário do grupo. Segundo Motter (1994), "esse episódio dos vetos tem sido rememorado sempre como a maior conquista da radiodifusão privada no Brasil" (1994, p. 146). Embora os empresários tenham sido conhecidos como tradicionalmente unidos pela defesa do mercado e pelos interesses da radiodifusão privada, nem sempre foi assim. No final da década de 1960, o grupo sofreu uma cisão em função de uma Comissão Parlamentar de Inquérito (CPI), que havia sido criada para investigar o acordo $^{17}$ feito entre a Time Life e a Globo, que era contra as regras do segmento de comunicação da época. A Globo acabou aceitando recursos do capital estrangeiro, fortalecendo-se, e a CPI não foi adiante. O fato, porém, provocou o afastamento da Globo da Abert, que, em represália, liderou outra associação, a Associação Brasileira de Televisão (Abrate), que perdurou até 1974. Na ocasião, “os principais líderes da classe chegaram a um acordo para reintegrar a Globo à Abert” (MOTTER, 1994, p. 146).

Após alguns ajustes e gestões mais neutras, sem ligação direta com a Globo nem com as pessoas que ficaram contrariadas com o acordo Time Life/Globo, o segmento voltou a ficar unido e consolidado. De acordo com a publicação da própria Abert ${ }^{18}$, "no final dos anos de 1970 a dissidência foi enterrada definitivamente, inclusive pelo empenho da própria Globo, que era para a radiodifusão do período o que os Diários Associados haviam sido nas décadas anteriores." A partir de então, nos anos seguintes, os laços entre a Abert e o Governo se

\footnotetext{
${ }^{17}$ Este acordo permitiu que a TV Globo tivesse uma injeção de recursos da ordem de 6 milhões de dólares por parte do grupo americano Time Life. Isso foi considerado inconstitucional perante a Constituição, à época, que impedia a entrada de capital estrangeiro nas empresas de comunicação.

${ }^{18}$ Revista Abert no 27 , de novembro de 1987, p. 12.
} 
fortaleceram, a ponto de o então ministro das Comunicações do Governo Sarney, Antônio Carlos Magalhães, em almoço no Iate Clube de Brasília, em 10 de dezembro de 1987, na comemoração dos 25 anos de existência da Associação, ter declarado em seu discurso que:

O Poder Público tem que agradecer a existência dessa entidade, que comemora o seu Jubileu de Prata, e tem prestado serviços em todos os sentidos ao governo da República, nas áreas estaduais e municipais (...)

Desde que foi criada, a Abert passou a ser interlocutora privilegiada do Governo na definição de políticas para o setor de comunicação, especificamente, para a área da radiodifusão. Essa participação tornou-se mais efetiva no período do governo Sarney. Na ocasião do aniversário da entidade - citada acima - o então presidente Joaquim Mendonça declarou que "a consulta prévia a Abert, pelo Governo, sempre que novas normas precisam ser editadas constituiu-se em saudável rotina então introduzida" (MOTTER, 1994, p. 148).

Com expressivo apoio do Governo, a Abert seguiu unida para enfrentar os debates na arena da Constituinte, os empresários da radiodifusão unidos pela lógica do mercado e convencidos de que "o Estado deveria assumir a responsabilidade de garantir a viabilidade dos negócios privados na área da radiodifusão. A intervenção estatal é desejada e invocada pelo empresariado do setor, para que a reserva de mercado seja garantida" (Idem, 1994, p. 150). Segundo Motter, “essa posição esclarece os limites do discurso liberal que será esgrimido nos debates sobre a questão durante o processo constituinte" (Idem, 1994, p. 150).

Depois de muitas reuniões, simpósios e encontros da classe, assim como também fez a Fenaj e as entidades sociais que lutam pela democratização dos meios, a Abert chegou a um consenso sobre o documento de proposições que defenderia durante os trabalhos da Assembleia Nacional Constituinte. Nele, a entidade pede mais liberdade de atuação, "de forma que a mídia eletrônica tenha a mesma liberdade da imprensa escrita"19 e que o critério de concessão de canais de radiodifusão seja mudado e a concessão definida por uma comissão tríplice, com um representante do Governo, por meio do Ministério da Comunicação, um representante do Congresso e um representante da Abert.

No último congresso da Abert, antes de iniciar as audiências públicas da Constituinte, os empresários do setor dedicaram-se a discutir os temas que seriam levados e defendidos aos parlamentares simpatizantes da causa privatista. O então presidente da Abert, Joaquim Mendonça, em seu discurso de abertura, tentou tranquilizar os radiodifusores sobre os riscos da Constituinte,

\footnotetext{
${ }^{19}$ Sugerida mudança nos critérios de concessão. O Estado de S. Paulo, 12/10/86, p. 24.
} 
...seja que tratamento for o que será dado à imprensa pelo texto constitucional, cumpre-me repetir o óbvio: sem imprensa livre não há democracia, assim como sem democracia não há imprensa livre. E não há imprensa livre sem iniciativa privada, múltipla, diversa, séria e economicamente independente. ${ }^{20}$

Em seguida, Mendonça fez a seguinte advertência ao setor, para a ameaça representada pelas propostas que questionam a radiodifusão privada: “vozes totalitárias, de esquerda e de direita, arrogando-se em intérpretes do interesse popular paralelamente aos seus legítimos representantes eleitos, pleiteiam controles, censuras, representações comunitárias e sindicais, e não se sabe mais quantas restrições". ${ }^{21}$

E foi movida com esse espírito privatista e monopolizante que a Abert chegou à mesa de negociações da Assembleia Nacional Constituinte, tendo como eixo central "o combate sistemático a qualquer proposta que modifique o sistema da radiodifusão baseado na exploração privada e na subordinação da liberdade de imprensa à radiodifusão privada". ${ }^{22}$

\subsubsection{O palco da Subcomissão de Ciência, Tecnologia e Comunicação}

Durante a Constituinte, foi na Subcomissão de Ciência, Tecnologia e Comunicação que os dois lados mais antagônicos da disputa em torno da democratização da mídia se confrontaram e a temperatura dos debates subiu. A relatoria ficou a cargo da deputada Cristina Tavares (PMDB-PE) que, além de ser jornalista, era conhecida por sua militância a favor das causas democráticas. Já o presidente da subcomissão, o deputado Aroldo de Oliveira (PFL-RJ), era conhecido por seu perfil conservador e pela liderança junto à bancada dos evangélicos. Ele ocupou vários cargos ligados ao setor das telecomunicações, foi diretor da Embratel, vice-presidente da Telerj e atuou no Ministério das Comunicações. Na época da Constituinte, havia denúncias de que ele seria sócio da uma emissora de TV no Rio de Janeiro.

De acordo com a pesquisa de Motter,

Uma das bancadas mais numerosas da Constituinte foi, sem dúvida, a "bancada do rádio", integrada por parlamentares que detinham concessões de emissoras de rádio e televisão. Essa bancada - que alcançou o expressivo número de 146 parlamentares, o que significava $26 \%$ dos 559 constituintes cresceu assustadoramente durante o processo constituinte graças ao elevado

\footnotetext{
${ }^{20}$ Revista Abert, $\mathrm{n}^{\mathrm{o}}$ 17, outubro de 1986, p. 11.

${ }^{21}$ Revista Abert, $\mathrm{n}^{\text {o }}$ 17, outubro de 1986, p. 11.

${ }^{22}$ Revista Abert, $n^{\circ}$ 18, nov./dez. 1986 p. 5.
} 
número de concessões distribuídas pelo governo Sarney no período ${ }^{23}$ (MOTTER, 1994, p. 163).

Esse grupo de parlamentares teve participação fundamental na subcomissão, com o intuito de garantir os privilégios dos proprietários de rádio e televisão. $\mathrm{Na}$ subcomissão, de acordo com o perfil ideológico levantado pelo jornal Folha de S. Paulo ${ }^{24}$, pelo menos oito dos 21 membros da subcomissão da comunicação possuíam vínculos pessoais com o status quo da radiodifusão, sendo que dois terços pertenciam ao centro, centro-direita e direita, ou seja, apenas um terço dos parlamentares era aliado da causa pela democracia dos meios.

Depois de exaustivas discussões sobre a condução dos trabalhos da Constituinte, começaram a acontecer as audiências públicas. Como afirmado anteriormente, "a realização de audiências públicas, prevista no Regimento da Constituinte, foi sem dúvida o momento mais rico de todo o processo de elaboração constitucional. Essas audiências com representantes das mais diversas correntes de opinião permitiram uma interlocução com a sociedade civil” (MOTTER, 1994, 205).

$\mathrm{Na}$ primeira audiência, o presidente da Fenaj, Armando Rollemberg, teve a oportunidade de apresentar a proposta das entidades que defendiam as políticas democráticas para a comunicação. Ao final da apresentação (cada convidado tinha direito a 20 minutos de fala), Rollemberg foi bastante enfático e afirmou que "o problema da democratização da mídia está diretamente ligado à questão da democracia da mídia” (Idem, p. 207).

Se queremos ter uma democracia neste país, temos que começar a pensar seriamente em criar mecanismos para desmontar essa estrutura oligopolizada, que dá aos donos das grandes redes um poder muitas vezes maior do que tem o próprio presidente da República. Não é exagero. É fato. Hoje o poder da Rede Globo sobre a sociedade brasileira é inatingível, inclusive pelo presidente da República, inclusive pelos órgãos constituídos dos Poderes da República. ${ }^{25}$

Nessa mesma audiência, foram ouvidos o presidente da Associação Nacional dos Jornais (ANJ) e então diretor do Jornal do Brasil, Nascimento Brito, e o empresário Roberto Civita, do Grupo Abril e também presidente da Associação Nacional dos editores de revistas (Aner). Os empresários, naturalmente, defenderam o livre mercado e criticaram a proposta da Fenaj, com ênfase na criação do Conselho Nacional de Comunicação.

\footnotetext{
${ }^{23}$ O presidente José Sarney outorgou o expressivo número de 1.028 emissoras para garantir o mandato de 5 anos.

${ }^{24}$ Os eleitos - Quem é Quem na Constituinte. Folha de S. Paulo, caderno especial, 19/01/87, p. 1-8.

${ }^{25}$ Diário da Assembleia Nacional Constituinte (Danc), v. 3, 14/05/87 apud MOTTER, 1994, p. 207.
} 
Nascimento Brito propôs que a Constituição se preocupe apenas em garantir a liberdade de expressão, deixando o resto para a lei ordinária. Ele aproveitou para criticar a proposta de criação de um Conselho de Comunicação, justificando que o Congresso Nacional é suficientemente representativo para fiscalizar o problema da liberdade de expressão no País (MOTTER, 1994, p. 208).

O presidente da Aner, por sua vez, fez coro com Nascimento Brito e ainda defendeu "que a livre iniciativa é a melhor garantia da multiplicidade de vozes tão fundamentais para a existência de uma sociedade aberta, pluralista e democrática" (Idem, p. 209). O deputado Carlos Alberto Caó (PDT-RJ), simpatizante das bandeiras dos movimentos sociais, reagiu logo após a exposição de Civita:

a livre iniciativa não tem assegurado o pluralismo de opinião na mídia, conduzindo, pelo contrário, a uma crescente oligopolização dos meios de comunicação de massa que, por sua vez, deixam de estar a serviço da sociedade, da opinião, para se transformar em instrumentos de poder político, competindo com as instituições formadoras da sociedade política (MOTTER, 1994, p. 210)

Em meio ao caloroso debate, Civita lançou mão do mesmo argumento que Paulo Tonet, da Associação Nacional dos Jornais (ANJ), usou em 2009 para criticar a possibilidade de ser adotado qualquer tipo de controle sobre os meios de comunicação. De acordo com o Diário da Assembleia Nacional Constituinte (Danc), Civita afirmou que, com todas as falhas da economia de mercado, esse é ainda o melhor sistema para garantir a pluralidade. Com relação ao poder da mídia questionou assim:

Que poder é esse da mídia que depende do telespectador não girar o seletor, não acionar o controle remoto? Que fantástico e monstruoso poder consegue obrigar os leitores a comprar o próximo número de determinado jornal ou revista? Que poder é esse afinal? E concluiu: Deixem o mercado decidir (DANC, 14/5/87 apud MOTTER, 1994, p. 210).

Qualquer semelhança entre um discurso e outro não é mera coincidência. Passados 22 anos, Tonet afirmou em entrevista à Folha de S. Paulo, no primeiro dia de debates da Confecom, que: “o controle social da mídia já existe: é o controle remoto e o jornal de banca. Fora disso é censura e eu não quero mais" ${ }^{26}$. Nas reuniões que se seguiram, durante as audiências públicas da Constituinte, outros empresários foram ouvidos, bem como representantes de outras entidades sociais, sendo que na oitava reunião o representante da

\footnotetext{
${ }^{26}$ Tribunal da mídia está entre as propostas de governo, Folha de S. Paulo, 14/12/2009.
} 
Abert, Fernando Ernesto Côrrea, voltou a insistir que o controle dos meios já está nas mãos do cidadão e que no Brasil não há monopólio: "se há um país em que não há monopólio na televisão é o Brasil. Quer dizer, aqui não há monopólio na televisão. Mudar o produto é virar o dial (...). Se não quero os produtos desligo a televisão" (MOTTER, 1994, p. 213). Para esse autor, a audiência exercida pela TV Globo é um problema conjuntural que será resolvido com o aumento da concorrência.

O então deputado Olívio Dutra (PT/RS), que era membro da subcomissão, contestou as posições defendidas pelos empresários, alegando "que a liberdade de imprensa não pode ser confundida com mera liberdade de quem detém o controle dos meios de comunicação de massa" (Idem, p. 215). Dutra fez, em seguida, esta importante observação:

...de todos os depoimentos colhidos na subcomissão com representantes da ANJ, Fenaj e Aner, por exemplo, a imprensa só noticiou a posição empresarial, ignorando por completo as propostas dos jornalistas, o que só comprova a parcialidade da imprensa, e com relação à Globo é incontestável que ela exerce um virtual monopólio, pode até ceder aqui e ali, mas o faz exatamente para não perder esse monopólio ${ }^{27}$ (DUTRA apud MOTTER, p. 125).

O olhar sobre essas audiências e debates, que ocorreram em 1987/88 - cujos exemplos mais relevantes foram trazidos aqui -, mostra que os discursos manifestos tanto de um lado como de outro pouco se alteraram nesses últimos 20 anos. Os empresários do setor de mídia continuam argumentando que eventuais mecanismos de acompanhamento e fiscalização da mídia, como foi ilustrado, podem desencadear a volta da censura. As entidades que defendem a democratização dos meios, por sua vez, continuam insistindo que são necessários mecanismos legais que impeçam a concentração da propriedade das emissoras de rádio e televisão, para que o direito à comunicação seja, de fato, garantido e universalizado.

\subsection{Após a nova Carta}

Depois da promulgação da Carta, o então presidente Sarney continuou a distribuir concessões, pois precisava "agradecer" o apoio recebido pelos cinco mandatos. "O oferecimento de concessões sempre foi usado como importante moeda de troca pelos mais diversos governos brasileiros. Nessas barganhas, saíram favorecidas as grandes redes que viriam aumentar o número de emissoras afiliadas e o grau de cobertura de sua programação" (PIERANTI, 2009, p. 419). No governo de Fernando Henrique Cardoso, todavia, o cenário

\footnotetext{
${ }^{27}$ Danc, v. 2, 14/5/87, p.181 apud MOTTER, 1994, p. 215.
} 
não foi muito diferente, pois embora tenha baixado o Decreto $\mathrm{n}^{\circ} 1.720$, em 1995, $\operatorname{logo}$ no começo do seu mandato, estabelecendo limites à outorga de concessões, o setor encontrou as brechas que precisavam para burlar seus limites.

O ministro das Comunicações, de então, considerado homem forte do Governo, o engenheiro Sérgio Motta, disse que "graças ao decreto estava-se iniciando um processo de moralização no que tange à outorga de concessões", pois o decreto tornava obrigatória a abertura de licitação para a concessão de emissoras de radiodifusão e os candidatos tinham de atender a uma série de exigências e pré-requisitos.

Mas os empresários encontraram uma lacuna na legislação, que deixou as estações retransmissoras de televisão (RTVs) de fora da exigência de licitação, ou seja, não eram alvos do Decreto $\mathrm{n}^{\mathrm{o}}$ 1.720. Por isso, desde 1978, as RTVs, por serem meras repetidoras de programação, tiveram seu funcionamento autorizado apenas por uma portaria do Ministério das Comunicações (Minicom).

A obtenção de uma RTV, portanto, passou a ser mais atraente e, além de mais barata, com legislação mais flexível. Na ocasião, o Minicom distribuiu nada menos que 1.848 RTVs, às vésperas da votação da emenda da reeleição de FHC, sendo que, destas, 527 foram para empresas de comunicação e outras 268 a empresas ou entidades ligadas a políticos (PIERANTI, 2009, p. 419).

\subsection{Privatizações no Governo FHC}

No governo de Fernando Henrique (1994/2002), o País assistiu ao processo de privatização das telecomunicações e em 1997 foi aprovada a Lei $n^{\circ}$ 9.472, de 16 de julho daquele ano, que criou a Agência Nacional de Telecomunicações (Anatel). Essa lei revogou, parcialmente, o Código Brasileiro de Telecomunicações e foi mais uma peça no grande mosaico em que se transformou o cenário da legislação sobre as comunicações no País.

A grande popularidade de Fernando Henrique Cardoso no combate à inflação e uma legislatura no Congresso Nacional recém-eleita contribuíram para que o Governo conseguisse aprovar a Emenda Constitucional $\mathrm{n}^{\mathrm{o}}$ 8, que quebrava o monopólio das telecomunicações no País. Segundo Souza (1998),

em dezembro de 1996, o ministro Sergio Motta encaminhou ao Congresso Nacional uma proposta muito antecipada de uma lei geral de telecomunicações, o esforço mais abrangente para regulamentação do setor desde a Lei $\mathrm{n}^{\circ}$

4.117/1962 (Código Brasileiro de Telecomunicações (CBT)), em que foram 
definidos não só atribuições e calendário de instalação do órgão regulador, mas o processo e as condições para a privatização do sistema de telecomunicações.

$\mathrm{Na}$ sua mensagem, em que apresentava a proposta da lei, Mota "fez pleno uso do jargão hegemônico da época" (SOUZA, 1998):

\begin{abstract}
A reforma estrutural das telecomunicações no Brasil "tem sido discutida e implementada no contexto de profundas transformações do setor em todo o mundo, que são ditados por três forças inter-relacionadas e reciprocamente determinados: a globalização da economia; a evolução tecnológica e a velocidade das mudanças no mercado e nas necessidades dos consumidores. ${ }^{28} 4$
\end{abstract}

Motta lembrou ainda que o Código Brasileiro de Telecomunicações, que era de 1962, estava defasado e havia sido herdado de "um tempo em que o mercado era essencialmente monopolista e não diversificado, e de um período tecnológico obsoleto”. Também destacou que o Brasil era signatário do Acordo Geral sobre Serviços (GATS) cuja reunião tinha sido realizada em Marrakesh, Marrocos, em abril de 1994, onde havia um entendimento de que o acordo definia princípios e regras universais para a crescente liberalização e concorrência nos serviços de telecomunicação.

Para convencer o Congresso da necessidade de mudanças, o ministro apresentou três argumentos irrefutáveis: o de que o Brasil necessitava de infraestrutura de telecomunicações adequada para crescer no cenário mundial; que os países mais desenvolvidos estariam trabalhando juntos para desenvolver essa infraestrutura; e que o Brasil, como um país em desenvolvimento, deveria participar da verdadeira revolução tecnológica, que estava ocorrendo em escala mundial, para saltar etapas e estimular seu desenvolvimento socioeconômico.

Segundo artigo de Lima (1998), esse processo, que foi desencadeado a partir do Governo FHC, coadunou com um processo maior que já estava em curso nos mercados mundiais:

Esse inédito processo de oligopolização e emergência de novos e poderosos atores no cenário econômico e político mundial tem sido justificado pelos executivos (CEO) do setor, como correspondendo ao processo biológico de sinergia. Argumentam eles que, considerando que os investimentos necessários são muito elevados, a integração horizontal, vertical e cruzada da indústria de

\footnotetext{
${ }^{28}$ Projeto de Lei Geral das Telecomunicações Brasileiras. Brasília: Ministério das Comunicações, 1998. Exposição de Motivos nº 231/MC apud SOUZA, 1998.
} 
comunicações, isto é, a ação coordenada de várias empresas, no mesmo grupo, torna-se inevitável e é mais eficiente do que a de empresas isoladas. ${ }^{29}$

Lima sugere que era um processo quase inevitável e avassalador, o que reforçou um modelo prevalente no País, desde a redemocratização. Segundo ele, outro fator decorrente desse padrão internacional que se verificou na década de 1990, foi "a presença dos organismos internacionais - nos quais as megaempresas e os Estados nacionais que partilham seus interesses estão representados, atuando como poderosos atores na formulação das políticas públicas nacionais e internacionais do setor das telecomunicações” (LIMA, 1998).

Para o professor, esse movimento universal que também se deu no Brasil assumiu aqui características próprias:

primeiro, por que fortalece e consolida - através da expansão horizontal, vertical e cruzada da propriedade - a posição já hegemônica de um único grupo nacional - as Organizações Globo; e, segundo, porque mantém inalterado o histórico domínio do setor por uns poucos grupos familiares e pelas elites políticas locais e/ou regionais.

As mudanças na legislação produzidas pelo então presidente Fernando Henrique, que criaram as condições legais para a abertura do mercado brasileiro, só reforçaram o mesmo status quo que sempre se observou no mercado de mídia do País.

No Brasil, essa presença internacional pode ser verificada a partir das profundas transformações que vêm ocorrendo desde o início do governo de Fernando Henrique Cardoso: a Lei do Cabo (Lei $\mathrm{n}^{\circ}$ 8.977/1995), que permite a participação estrangeira em até $49 \%$ do capital das concessionárias; a quebra do monopólio estatal das telecomunicações (EC n ${ }^{\circ}$ 08/1996); a Lei Mínima (Lei ${ }^{\circ}$ 9.295/1996), que permitiu a entrada de capital estrangeiro nas áreas de telefonia celular e das telecomunicações via satélite, no limite de 49\%, até julho de 1999; e a Lei Geral de Telecomunicações (Lei $n^{\circ}$ 9.472/97), que autoriza o Poder Executivo a estabelecer quaisquer limites à participação estrangeira no capital de prestadora de serviços de telecomunicações.

\footnotetext{
${ }^{29}$ Globalização das comunicações: o novo e o velho no sistema brasileiro. Venício Lima, 5/7/98. Disponível em: 〈http://www.observatoriodaimprensa.com.br/artigos/jd050798a1.htm>.
} 


\subsection{O começo da TV a cabo no País}

Embora o primeiro ato regulatório que disciplinou o serviço de TV por assinatura no Brasil tenha sido baixado em 1988, sua origem remonta à década de 1970 . O primeiro decreto foi o de $\mathrm{n}^{\circ}$ 95.744, de 23 de fevereiro de 1988, mas desde 1971, "quando a indústria de TV a cabo ainda engatinhava nos Estados Unidos" (DUARTE, 2005, p. 326), a Globo já dava os primeiros passos para sair na frente. A Globo criou, em 1971, a primeira TV a cabo no País, a TVC, em sociedade com o engenheiro eletrônico, Wilson Brito, que logo deixou o projeto, "provavelmente ciente da alta oposição no Governo, que retardaria o florescer do setor por mais de duas décadas e, ainda, ilustraria o controverso relacionamento que a empresa teria com o Governo" (DUARTE, 2005, p. 326).

Essa experiência da Globo foi bastante precária, mas deu sinais de que a empresa teria de se reposicionar para sobreviver ao desafio da TV paga. Mais bem sucedido, pelo menos no início do processo, foi o empreendimento do grupo Abril.

A última geração da família Civita (Abril), Mathias Machline (Sharp) e outros empresários empreendedores, advindos dos mais variados setores econômicos, arriscaram milhões para criar os primeiros experimentos de sucesso nos anos de 1980, que iriam, eventualmente, atrair a implementação da legislação adequada e, dessa forma, tornar viável a nova indústria (DUARTE, 2005, p. 327).

Tecnicamente, no início dos anos de 1980, era viável captar sinais de redes estrangeiras, e o Grupo Abril viu na TV paga sua oportunidade de entrar no segmento de televisão, que já era dominado pela Globo. Em 1989, a Abril criou o Canal $+{ }^{30}$, depois transformado na TVA, mas assim que começaram as transmissões a TV Globo entrou em ação para boicotar o empreendimento.

No mesmo dia em que TVA começava suas transmissões experimentais, a TV Globo transmitia anúncios ao longo do dia pedindo às pessoas que não assinassem nenhum serviço de televisão paga sem, antes, conhecer os serviços da Globosat. O anúncio, intitulado "não assine sem ver", teve duplo significado. Era uma clara demonstração de força para retardar a adversária e também um sinal de indecisão da Globo em relação ao crescimento da TV paga (DUARTE, 2005, p. 328).

\footnotetext{
${ }^{30} \mathrm{O}$ nome dado a esse canal foi inspirado no nome e no logotipo do homônimo francês que transmitia a programação do canal norte-americano ESPN, através do canal UHF 29, em São Paulo (DUARTE, p. 328).
} 
Havia um senso comum - equivocado -, na ocasião, de que a sociedade não iria pagar por algo que era tradicionalmente ofertado de graça, como a programação da TV aberta. De qualquer forma, a Globo atrasou um pouco um processo que ela mesma havia iniciado anteriormente e, depois, teve que correr atrás para não perder espaço. Em 1988, tanto a Abril como a Globo haviam recebido concessões para canais UHF por assinatura, no Rio de Janeiro e em São Paulo, mas a Globo não havia decidido utilizar sua concessão.

Com a Globosat, a empresa passou a utilizar outra tecnologia, a transmissão via satélite, na Banda C, "a mesma utilizada por muitos brasileiros afastados de uma das retransmissoras da Globo por todo o País" (DUARTE, 2005), o que trouxe competitividade à empresa. Como ocorreu nos Estados Unidos, os sistemas de radiodifusão paga via $\mathrm{UHF}^{31}$, $\mathrm{VHF}^{32}$ e $\mathrm{MMDS}^{33}$ não chegaram a ganhar mercado "e o controle dos céus representou algumas vantagens competitivas à Globo" (Idem, 2005).

Para evitar limitações legais, pois ainda não havia ocorrido a regulamentação da TV paga nem tampouco a distribuição direta via satélite, Roberto Marinho injetou mais capital para garantir o uso de antenas parabólicas e alugou quatro transponders ${ }^{34}$ bem antes que a própria companhia fosse formulada, pagando cerca de 400 mil dólares por mês para garantir que ninguém mais iniciasse operações antes de, pelo menos, 2 anos, quando mais transponders iriam estar disponíveis ${ }^{35}$. Pelo sistema em DHT (direct-to-home), a Globo teve mais liberdade com parceiros internacionais, pois não ficava sujeita às limitações técnicas do UHF/MMDS.

Embora estivesse mais preparada tecnologicamente, "o pacote da Globosat era inferior ao da TVA, oferecendo menos canais a preços significativamente mais altos e requerendo a instalação de grandes antenas - o que naquela época era pouco viável nas grandes cidades. "A TVA saía na frente da Globo no primeiro momento, mas a Globo já engendrava outra vantagem competitiva com a criação de canais próprios com a utilização de conteúdo barato

\footnotetext{
${ }^{31}$ VHF é a sigla para o termo em inglês very high frequency (frequência muito alta), que designa a faixa de radiofrequências de 30 a $300 \mathrm{MHz}$ (ideais para comunicações terrestres de curta distância).

${ }^{32}$ UHF é a sigla para o termo em inglês ultra high frequency (frequência ultra alta). Designa a faixa de radiofrequências de $300 \mathrm{MHz}$ até $3 \mathrm{GHz}$. É uma frequência comum para propagações de sinais de televisão e de canais em HDTV, rádio, transceptores, bluetooth e redes wireless.

${ }^{33}$ MMDS: Serviço de Distribuição Multiponto Multicanal, também chamada de Cabo Wireless. É uma tecnologia de telecomunicação sem fio, usada para redes de banda larga de uso geral, ou, mais comumente, como um método alternativo de recepção de programação de televisão a cabo.

${ }^{34} \mathrm{O}$ transponder (abreviação de transmitter-responder) é um dispositivo de comunicação eletrônico usado também na codificação de TV via satélite.

${ }^{35}$ Roberto Marinho deu a Globosat para Boni e seu amigo americano. Folha de S. Paulo, 16/6/91, p. 5.
} 
importado" (DUARTE, 2005, p. 330). A Globo reagiu e logo tomou a dianteira. Em 1992, o grupo Globo decidiu separar as operações de distribuição e geração de sinais em duas empresas distintas e uma delas originou a NET Brasil, que começou a adquirir pequenos operadores de cabo.

Em 1996, o grupo Abril, que havia inicialmente dominado a televisão por assinatura no País, viu-se pressionado pelas investidas da Globo que, literalmente, ganhava terreno a cada dia. Falhas gerenciais haviam praticamente eliminado as vantagens competitivas da pioneira Abril, em face do rígido profissionalismo da Globo. A Abril ainda tentou novas parcerias, inclusive com a Globo, mas não evoluiu. Daí surgiram as novas legislações para a TV paga, como será explicado adiante, e a Globo juntou-se com a News Corp. e a Televisa do México, o que ampliou sua participação no mercado.

No início dos anos 2000, a evolução da TV a cabo parecia incontestável, porém a holding havia investido pesado e contraído muitas dívidas, pois além do investimento em conteúdos, havia também os custos com o sistema de satélite, que era muito pesado, e a Globo teve "que se reinventar, abrindo capital para parceiros financeiros e deixando que a nova atividade da TV paga sacudisse toda a empresa" (DUARTE, 2005, p. 335). Mais tarde, "graças a um empurrão da Globo", o Congresso Nacional aprovou a emenda n 222 à Constituição, permitindo a entrada de capital estrangeiro nas empresas de comunicação, o que ajudou a empresa a renegociar suas dívidas. Hoje, a empresa tem papel expressivo no mercado, mas não está sozinha, pois teve de vender grande parte do seu capital acionário.

Atualmente, o mercado de TV paga no País está em franco crescimento. O número de assinantes cresceu $11 \%$ em 2014, devendo chegar a 20 milhões, segundo dados da ABTA divulgados pelo jornal Folha de S. Paulo ${ }^{36}$. Segundo a ABTA, esse número significa um alcance de 64 milhões de telespectadores.

Enquanto a tecnologia avança, os legisladores brasileiros discutem normas e leis que consigam acompanhar a rápida evolução do mercado da comunicação. De certa forma, isso ocorreu também com a Lei do Cabo $\mathrm{n}^{\mathrm{o}} 8.977 / 95^{37}$, que demorou a ser aprovada e quando aconteceu foram precisos 2 anos para sua regulamentação. Embora tenha sido modificada e

\footnotetext{
${ }^{36}$ Mercado de TV por assinatura aumenta a participação na classe C. Folha de S. Paulo, 29/7/2014. Disponível em:<http://www1.folha.uol.com.br/mercado/2014/07/1492780-mercado-de-tv-por-assinatura-aumentaparticipacao-na-classe-c.shtml>.

${ }^{37}$ Essa lei define os serviços de TV a cabo como serviços de telecomunicações que consistem nadistribuição de sinais de vídeo e/ou áudio, a assinantes, mediante transporte, por meios físicos.
} 
atualizada pela Lei $\mathrm{n}^{\circ} 12.485 / 11$, que, entre outras coisas, cria um sistema de cotas para conteúdo nacional nas TVs por assinatura, é importante registrar o momento e as discussões que ensejaram sua aprovação.

É possível afirmar que as tratativas que culminaram na aprovação da lei, foi em um momento - depois da promulgação da Constituição de 1988 - no qual o tema da democratização da mídia voltou ao debate nacional com intensidade. Mais uma vez, dois lados clássicos do embate midiático - o setor privado de mídia e as entidades sociais voltaram a discutir a questão da política de comunicação para o País. Esse encontro se intensificou entre os anos de 1995 e 1997, quando, enfim, o segmento foi regulamentado, ocasião em que as limitações de número de licenças por empresa e por município, por exemplo, foram definidas, mexendo com a hegemonia da TV Globo e com a concentração da propriedade das emissoras de radiodifusão.

De acordo com a tese de doutorado do professor e pesquisador Sérgio Euclides de Sousa $^{38}$,

Dezenove meses após aprovação da Lei $\mathrm{n}^{\circ}$ 8.977/95, os operadores de cabo organizados na Associação Brasileira de Televisão por Assinatura (ABTA) estavam reclamando com o Ministério das Comunicações da lentidão 'para gerar o ambiente regulatório necessário' para a explosão econômica que era esperada para o setor (SOUSA, 1998).

Tudo indicava que a demora se devia às mudanças que estavam sendo feitas nas normas complementares, que iriam abrir algum tipo de brecha que não atrapalhasse os negócios da TV Globo e do Grupo Abril, que dominava o mercado. Segundo Sousa (1998),

Apesar do fato de o Minicom estar com disposição para limitar a quantidade de licenças por empresa ou filial - fixada em sete para áreas de serviço com mais de 700.000 habitantes, e 12 em áreas entre 300 mil e 700 mil - como foi antecipado no art. 38 do regulamento, dez meses antes, ela teria sido recebida com apreensão pela Globo e a Abril” (SOUZA, 1998).

Essa definição, com certeza, pode ser entendida como "um passo importante para a prevenção da oligopolização do serviço de TV por assinatura" (SOUSA, 1998). Mas não era bem assim. Apesar de o Ministério das Comunicações estar com a disposição de limitar a

\footnotetext{
${ }^{38}$ Autonomia elusiva. Tese (Doutorado em Comunicação) - Universidade do Colorado, Escola de Jornalismo e Comunicação de Massa, 1998.
} 
quantidade de licenças por empresa ou filial, isso acabou sendo contornado. Essa limitação fez com que a Globo vendesse parte das suas licenças.

Segundo a dissertação de Sousa (1998), "com uma leitura atenta de ambos” (o Globo e o Grupo Abril), sobre a norma de regulamento do serviço a cabo, seria possível observar que o Ministério das Comunicações ainda teria espaço "como último recurso em favor dos seus amigos, para contradizer suas próprias declarações legais”, em função de algumas questões técnicas. Como a não necessidade de limitar o número de licenças para áreas com menos de 300 mil habitantes, e a liberalidade permitida ao ministro para que - sempre que julgasse necessário e após consulta pública - dividir certa região em mais de uma área de serviço. Observando, naturalmente, que cada área tenha um potencial de mercado garantido.

Esse trecho é importante para ilustrar que, apesar de existir uma norma estabelecida depois de muita negociação, ainda assim seria possível encontrar brechas na lei que viessem favorecer as empresas que, tradicionalmente, exerciam sua hegemonia no segmento. Em outra passagem também está claro como eram as relações de favoritismo entre o Governo e determinadas empresas privadas.

$\mathrm{Na}$ ocasião da expectativa para a liberação das normas que iriam regulamentar o serviço de TV a cabo, definidas pela Lei no 8.977/95, em agosto de 1996, o então presidente da ABTA, Roger Karman, em entrevista à Folha de S. Paulo ${ }^{39}$, havia expressado sua impaciência e cobrado do então ministro das Comunicações, Sérgio Mota, uma definição do assunto, e reclamado da dificuldade em ter acesso ao próprio ministro. Além disso, Karman teria reclamado de que o setor já havia investido US\$ 1 bilhão de dólares no negócio e que a situação de indefinição gerava instabilidade para o mercado.

O então diretor de relações institucionais da ABTA, Antônio Carlos de Menezes, em entrevista à Sousa ${ }^{40}$, confidenciou suas percepções sobre Sérgio Motta, então ministro das Comunicações. "Menezes, um negociador de renome com acesso aos círculos de poder e (pela minha experiência com ele) um interlocutor obviamente reservado, "suspeita" que a impermeabilidade do ministro das Comunicações é seletiva": por exemplo, é sabido que logo após ter assumido o Minicom, Motta jantou com Roberto Marinho na residência do magnata da

\footnotetext{
${ }^{39}$ TVs pagas cobram ação do ministro. Folha de S. Paulo, 2/8/96 apud SOUZA, 1998.

${ }^{40}$ Tradução livre do inglês: Actually, I suspect that Menezes - then ABTA director of institutional relations, a reputed negotiator with access to power circles and (from my experience with him) an obviously reserved interlocutor - "suspects" that the Minister's imperviousness is selective: for example, it is known that just after assuming Minicom, Motta dined with Roberto Marinho at the media mogul's residence in Rio de Janeiro reportedly "to discuss the government's proposed changes in telecom licensing procedures.
} 
mídia, no Rio de Janeiro, supostamente "para discutir mudanças propostas pelo Governo nos procedimentos de licenciamento das telecomunicações"41.

Na interpretação do professor Sérgio Euclides de Sousa,

"negar no varejo o que é anunciado por atacado" (parafraseando um aforismo popular brasileiro) é o que práticas enganosas do tipo acima são. Eles são exemplares, na história da lei de comunicação do País e da política, de como os donos do Poder são engenhosos enquanto assimilam, retoricamente, as demandas políticas, trabalham para matá-las administrativamente. A burocracia das telecomunicações do Estado (pelo Minicom), seus aliados no Congresso Nacional e os beneficiários privados têm dominado essa "arte", especialmente quando as mudanças estruturais na década de 1980 e depois (descrito aqui em seus níveis globais e nacionais, nas suas dimensões socioeconômicas, políticas e tecnológicas) estavam ameaçadas, e, finalmente, corroído o caráter monolítico da aliança entre a mídia e o Estado privatista, que, para o melhor e para o pior, construiu o maior do mundo - e tecnicamente mais sofisticado - a indústria cultural entre os chamados países em desenvolvimento (SOUSA, 1998). ${ }^{42}$

Apesar de privilégios ainda obtidos pelas empresas que dominam o segmento da TV a cabo, a legislação foi importante e abriu espaço para novos avanços, no sentido de controlar o mercado de televisão e aumentar a participação da sociedade na gestão dos meios. Em sua conclusão, Sérgio Euclides, após problematizar a questão da privatização e da re-privatização no Brasil, destaca que, para o aprimoramento da democracia,

estratégias e táticas políticas e legais deveriam ser desenvolvidas diante das instituições existentes da democracia representativa (o executivo, o legislativo e, agora, a agência reguladora de telecomunicações), com a finalidade de criar espaços públicos distintos em estruturas de comunicação social estatais e privadas, baseadas no reconhecimento de novas possibilidades para participação generalizada e socializada na

\footnotetext{
${ }^{41}$ Ministro janta com Marinho. Folha de S. Paulo, 7/2/95.

${ }^{42}$ Tradução livre do inglês: "Denying at retail what is announced by wholesale" (to paraphrase a Brazilian popular aphorism) is what deceptive practices of the kind above are about. They are exemplary, in the history of the country's communication law and policy, of how resourceful the owners of power can be in rhetorically assimilating political demands while working to kill them administratively. The state telecom bureaucracy (at Minicom), its allies at the National Congress and its private associates and beneficiaries have mastered this "art," especially when the structural changes in the 1980s and after (described here at their global and national levels, in their socioeconomic, political and technological dimensions) threatened, and finally eroded the monolithic character of the state-private media alliance which, for better and for worse, built the world's largest - and technically most sophisticate - cultural industry among the so-called developing countries. How (and in what direction) this alliance has been structurally transformed is now the focus of my attention, paving the way for the articulation of an analytically - as well as politically - acceptable answer to this dissertation's basic question: to what extent is it still possible for the Brazilian state to autonomously conceive and implement communications policies based on a common understanding of "the national interest"?
} 
produção de formas comunicativas e conteúdos abertos pelas novas tecnologias de comunicação ${ }^{43}$ (SOUSA, 1998).

\subsection{A curta história do Conselho de Comunicação Social}

O Conselho de Comunicação Social, previsto no art. 224 da Constituição, nasceu sob 'fórceps', e talvez por isso tenha tido vida tão curta e atribulada. Quando se fala na sua recriação, o setor privado de mídia se arma. Foi assim na Constituinte, repetiu depois, em 2002, e voltou a acontecer no palco da Confecom.

Conforme Jambeiro (2007), durante a Assembleia Constituinte a proposta de um conselho polarizou o debate em dois grandes grupos: de um lado, a Federação Nacional dos Jornalistas (Fenaj) que, diante de divergências com outros membros da Frente e da urgência de um interlocutor, impôs-se como representante das chamadas forças da sociedade civil organizada, e de outro, a Associação Brasileira das Emissoras de Rádio e Televisão (Abert), ligada aos parlamentares do chamado centrão ${ }^{44}$.

Enquanto os empresários capitaneados pela Abert defendiam que a radiodifusão devia ser controlada pelo Poder Executivo e explorada pela iniciativa privada "nos moldes estabelecidos pela legislação em vigor", a Fenaj defendia "a criação de um Conselho Nacional de Comunicação [...], um órgão coletivo autônomo com atribuições executivas e composto, na sua maioria, por representantes de entidades de trabalhadores e da sociedade civil" (JAMBEIRO, 2007, p. 82-83; 2001, p.146).

Para que o conselho constasse na Constituição foi preciso esvaziá-lo. "Depois de longas negociações, a Constituição, além de determinar "que a exploração dos serviços de TV deveria ser feita por entidades privadas, públicas e estatais" de forma complementar, estabeleceu que o conselho fosse apenas um órgão consultivo do Congresso, agora chamado Conselho de Comunicação Social, fixando, ainda, que as concessões fossem deslocadas do eixo do Poder Executivo para o Legislativo, pois deveriam ser aprovadas também pelo

\footnotetext{
${ }^{43}$ Tradução livre do inglês: The second way refers to the development of political and legal strategies and tactics before and/or within the existing institutions of representative democracy (the Executive, the Legislature, and now the telecom regulatory agency), with the purpose of creating distinctive public spaces in state and private media structures, based on the recognition of new possibilities for widespread, socialized participation in the production of communicative forms and contents opened by the new communication technologies.

${ }^{44} \mathrm{O}$ "centrão" foi um dos blocos políticos suprapartidários mais relevantes durante os debates da Assembleia Nacional Constituinte e tinha um caráter conservador em relação às propostas mais avançados que estavam em debate na ocasião.
} 
Congresso" (JAMBEIRO, 2007, p. 83). "Tornar o conselho apenas consultivo foi a saída para sua criação e, mesmo assim, contrariando as pretensões da Abert” (Idem, p. 83).

Apesar de todas as restrições, as entidades que defendiam a democratização da mídia brigavam pela sua instalação. Pouco tempo antes do início do governo FHC, em 1991, o conselho foi regulamentado, mas sua instalação demorou mais de 10 anos para acontecer. Apesar da demora e da expectativa, o conselho teve vida curta, pois foi instalado pelo Senado Federal e acabou sendo negociado pelo então presidente Fernando Henrique Cardoso.

A imprensa divulgou na época que FHC não queria entregar o cargo sem cumprir o compromisso assumido com os partidos de oposição e com as entidades representantes de setores da sociedade civil organizada, como o Fórum Nacional pela Democratização da Comunicação (FNDC), de ajudar na instalação do Conselho de Comunicação Social. FHC queria que o conselho fosse instalado antes que a Proposta de Emenda à Constituição (PEC), que permitia a entrada de $30 \%$ de capital estrangeiro nas empresas de comunicação, fosse votada. O conselho foi instalado em junho de 2002 e a PEC votada no dia 22 de dezembro de 2002, oito dias antes do fim do seu Governo. Algumas notícias da época chegaram a insinuar que teria sido feito um acordo nos bastidores entre o Governo, o Congresso e o setor privado, que queria muito a entrada de capital estrangeiro na mídia e, em troca, os empresários teriam de aceitar a instalação do conselho. Ou seja, de um lado agradou às entidades sociais e do outro os empresários do setor.

Para justificar tanta demora na instalação do conselho, o Senado Federal elaborou um relatório alegando dificuldades para sua composição. Como o conselho foi criado para assessorar o Congresso Nacional, o Senado entendeu que devia dar explicações pela sua não instalação. Nesse relatório, a justificativa para tal demora foi atribuída "aos critérios para a indicação dos representantes, a ausência de entidades representativas de caráter nacional, de algumas categorias profissionais" previstas na Lei do Conselho de Comunicação Social (art. $4^{\circ}$ ), entre outras. Foram necessários 10 anos para superar esses obstáculos.

O Conselho de Comunicação Social, segundo consta no art. $4^{\circ}$ da lei, que institui o órgão, deveria ser composto por um representante de cada entidade, alguém que falasse em nome das empresas de televisão, de rádio e da imprensa escrita; da categoria profissional dos jornalistas, dos radialistas, dos artistas e dos profissionais de cinema e vídeo; e também de um engenheiro dotado de conhecimento na área de comunicação social. Além, é claro, de cinco membros representantes da sociedade civil que, certamente, seriam a voz dos leitores e do público em geral. 
Todo o impasse em torno da criação do conselho foi criado pelos empresários do setor que resistiam à sua implantação. Apesar de ter sido aceito pelo setor privado, por ocasião da redação final da Constituição, os empresários não queriam que ele fosse instalado e passasse a funcionar em sua plenitude. Mesmo não tendo nenhum poder de deliberação, foi concebido com atribuições ousadas e importantes para a sociedade.

Sua principal atribuição, prevista no art. 224 da Constituição, ficou longe da que era desejada pelos representantes dos movimentos sociais, que sonhavam com um órgão deliberativo e com poder de influência junto ao Congresso, no tocante às outorgas e concessões de empresas de radiodifusão. Ao conselho coube a função de ser um mero órgão consultivo, sem nenhum poder de deliberação. Caberia a ele apenas "a realização de estudos, pareceres e recomendações" tanto com relação à outorga e renovação da concessão como a outros assuntos ligados à liberdade de expressão. Nem mesmo "recomendações e pareceres" os "donos da mídia” queriam que acontecessem, como de fato não aconteceram.

Apesar de todas as limitações impostas, assim que todos os nomes foram definidos, depois da aprovação da Câmara e do Senado, o conselho começou a funcionar, o que trouxe esperança para os representantes do movimento social, que esperavam o começo efetivo de mudanças no cenário. Em 2002, ano da IX Plenária do Fórum Nacional pela Democratização, o ponto alto dos debates foi a instalação do conselho. De acordo com o item $\mathrm{n}^{\mathrm{o}} 15$ da Conferência, o conselho apresentou equilíbrio na sua composição e foi celebrado pelo FNDC, como mostra o texto a seguir:

Trata-se [...] de um privilegiado espaço institucional que abre para a sociedade, democraticamente, condições de incidência sobre o Legislativo e o Executivo, viabilizando publicamente o que antes só estava ao alcance dos lobbies empresariais. É uma instituição de tipo novo que, tendo apenas funções consultivas, privilegia a política e a interlocução entre setores com posições contraditórias, possibilitando o equacionamento das demandas sociais e dos diversos interesses das partes (FNDC, 2002).

Havia muita expectativa naquele momento por parte das entidades sociais que lutavam pela democracia dos meios de comunicação. Era a possibilidade do estabelecimento de novas bases nas relações tripartite do segmento: Estado, setor privado e sociedade civil. Afinal, estava na Lei $\mathrm{n}^{\circ} 8.389$ tudo o que precisava para que os artigos do Capítulo $\mathrm{V}$ da Comunicação fossem regulamentados. As entidades, que lutaram tanto para que o conselho fosse instalado e para que um novo espaço de discussões se consolidasse, assistiram o esperado conselho morrer depois de apenas dois mandatos de 2 anos cada. 
Quando finalmente foi instalado, o que só aconteceu 14 anos depois da Constituição de 1988, nasceu sob 'fórceps' em meio às resistências dos empresários do conglomerado midiático, demonstrando ser um campo relativamente plural de discussões. Depois do final do primeiro mandato, em meados de 2004, deveria ter começado o segundo, porém houve muito atraso na escolha dos novos representantes e só em fevereiro de 2005 é que eles tomaram posse e, ao final do ano seguinte, "já estava totalmente esvaziado". Para o terceiro mandato, os representantes sequer foram escolhidos.

Embora o conselho não tenha tido o desempenho que se esperava, o presidente do FNDC, Schröder (2012), declarou na ocasião que "durante os anos em que o CCS funcionou, sob a presidência de José Paulo Cavalcanti Filho, teve uma atuação exemplar e produziu importante relatório sobre a concentração da mídia no Brasil”.

Na gestão seguinte, quando o conselho foi presidido pelo escritor Arnaldo Niskier, de acordo com o Observatório da Imprensa, "o fórum foi tomado pela lógica da hegemonia dos meios de comunicação". Segundo explicou Schröder (2012), "as empresas assumiram o papel das cinco cadeiras destinadas para a sociedade civil e, a partir daí, nós tivemos um conselho inócuo no primeiro momento e que, depois, desapareceu".

Segundo o jornalista Dines (2012), em editorial no site do Observatório da Imprensa:

A história desse conselho é trágica e joga uma penosa sombra não apenas sobre nossa mídia como também sobre nosso descaso com o disposto pela Carta Magna. Essa lamentável história tem apenas um protagonista: o senador José Sarney, que durante 14 anos procrastinou a instalação desse conselho (DINES, 2012). ${ }^{45}$

A história do conselho é só um capítulo na longa trajetória da indiferença com que os debates sobre democratização da mídia são tratados tanto pelo Congresso como pelo Poder Executivo. Em agosto de 2013, o conselho foi novamente constituído, de uma forma que desagradou não só os representantes dos movimentos sociais, bem como os parlamentares da Comissão de Ciência, Tecnologia, Comunicação e Informática da Câmara dos Deputados, presidida pela deputada Luíza Erundina (PSB/SP).

Erundina, que é também presidente da Frente Parlamentar pela Liberdade de Expressão e o Direito à Comunicação com Participação Popular, contestou o processo de escolha dos conselheiros em discurso no plenário da Câmara.

A deputada também argumentou que a escolha foi autoritária:

\footnotetext{
${ }^{45}$ Novela melancólica. Alberto Dines, editorial do Observatório da Imprensa na TV no 654 , exibido em 28/8/2012. Acesso em: 27 jan. 2012.
} 
Aqui fica novamente a denúncia, o repúdio à forma autoritária, nada democrática, do Congresso Nacional, do Senado Federal, na forma de encaminhar uma iniciativa que há muito deve, que é a eleição do novo Conselho de Comunicação Social e sua posse feita da forma mais clandestina possível, quando se trata de um espaço de representação da sociedade civil (ERUNDINA, 2013).

O conselho ficou desativado durante 6 anos. Atualmente, o tratamento dado ao novo colegiado sugere o tom com que o tema é tratado pelo Congresso Nacional.

\section{$1.7 \mathrm{O}$ cinema e outros meios audiovisuais}

No meio cultural a sensação era de frustração em relação ao governo Lula, pois artistas, cineastas e representantes dos movimentos em defesa dos avanços na legislação sobre cinema e vídeo apostavam em uma nova agência para o setor, que coadunasse com os novos tempos. Afinal, era o primeiro Governo de esquerda que chegava ao Poder, depois dos militares.

A versão do pré-projeto de transformar a Agência Nacional de Cinema (Ancine) em Agência Nacional de Cinema e Audiovisual (Ancinav), que incluísse também conteúdos audiovisuais, surgiu no final de 2004 e vazou para a imprensa. Isso foi o bastante para que os grupos tradicionais do setor fizessem uma "feroz e intensa campanha" contra. O Executivo acabou desistindo do projeto, alegando que antes de regular deveria ser votada uma lei para a comunicação eletrônica. Ele foi retirado de pauta pelo Governo.

Um dos objetivos da Ancinav é equilibrar as condições de participação da indústria cinematográfica e audiovisual nacional, em relação à produção internacional e ao monopólio de empresas de produção e distribuição de massa, resguardando e protegendo, com mecanismos especiais, a diversidade e a competitividade do mercado nacional. Segundo dados revelados à época, pelo Ministério da Cultura, " $90 \%$ dos filmes exibidos pela TV brasileira são produzidos nos EUA, menos de $10 \%$ da população brasileira frequenta cinemas, cerca de $75 \%$ do mercado exibidor brasileiro está ocupado por filmes norte-americanos e mais de $90 \%$ dos municípios brasileiros não possuem salas de cinema”(FORNAZARI, 2006, p.7) ${ }^{46}$.

Em artigo do cientista social e professor da Universidade Metodista de São Paulo, Fábio Kobol Fornazari, fica clara a pressão exercida pelas empresas de radiodifusão.

\footnotetext{
${ }^{46}$ Fornazari, Fábio Kobol. Reforma do Estado e Agências Reguladoras: o caso Ancine e Ancinav. 2006. In: $30^{\circ}$ encontro da Anpad.
} 
Fornazari (2006) relata a fala do cineasta Cao Hamburger que, na ocasião, chamou de "espinhoso" o processo de negociação. "As pressões sobre a criação da Ancinav foram imensas", ressaltou. Segundo Fornazari (2006), “a pressão das emissoras de TV levou à redução da agência ao âmbito do cinema” (FORNAZARI, 2006, p. 8).

O novo projeto "confrontou as arquipoderosas emissoras de TV", que se utilizaram do discurso pela "liberdade de expressão e livre iniciativa", para impedir a nova agência. Fornazari destacou que "o Governo, ao propor simultaneamente taxas e contribuições sobre vários segmentos (para criar recursos para o setor), gerou intensa reação por parte dos contrariados que, por pouco, não prejudicaram a negociação" (FORNAZARI, 2006, p. 9).

$\mathrm{O}$ argumento dos que apoiavam a mudança louvava "a volta do Estado brasileiro às suas responsabilidades constitucionais de mediador das questões econômicas ligadas à sobrevivência, ao desenvolvimento e ao saudável funcionamento de um setor produtivo, de extrema importância para o futuro do País" (MANIFESTO APROCINE, 2004).

Do lado dos que eram favoráveis ao modelo da nova agência estavam os diretores novos, produtores independentes e empreendedores de regiões fora do eixo Rio-São Paulo. Entre os que eram contra, apontou o artigo, estavam as redes de exibição, distribuidores estrangeiros, redes de telecomunicação, grandes produtores e cineastas "consagrados", das regiões mais desenvolvidas do País.

Organizados no "Fórum do Audiovisual e do Cinema", os cineastas mais conhecidos voltaram-se contra os riscos de partidarização, controle da produção artística e cultural, censura, centralismo, autoritarismo, imposição de conteúdo e desestímulo à livre iniciativa que a nova agência pudesse propiciar.

De acordo com Fornazari, o cineasta Arnaldo Jabor, presente ao encontro, declarou:

este projeto do Minc ambiciona muito mais do que regula o cinema ou a TV (...) visa controlar o pensamento, visa a um poder puro intocável, para uma infiltração na sociedade reflexiva, como uma tática "revolucionária" (...), pois a finalidade principal é colocar a TV Globo de joelhos, velho desejo totalitário (FORNAZARI, 2006, p. 666). ${ }^{47}$

Essa fantasia autoritária de Jabor poderia ter sido derrubada com uma simples consulta à minuta do projeto, art. $2^{\text {o: }}$ "A manifestação do pensamento, a criação, a expressão e a

\footnotetext{
${ }^{47}$ Fornazari, Fabio Kobol. Instituições do Estado e políticas de regulação e incentivo ao cinema no Brasil: o caso Ancine e Ancinav. RAP, Rio de Janeiro, v. 40, nº 4, p. 647-77, jul./ago. 2006.
} 
informação não sofrerão qualquer restrição ou censura de natureza política, ideológica e artística (...)". No "art. 4", VI - salvaguardar a liberdade de expressão e a diversidade de fontes de informação".

Para encerrar a polêmica, em janeiro de 2005, o Governo encaminhou ao Congresso um projeto de lei voltado para o investimento e a fiscalização audiovisual, e acalmou os setores que eram contra a Ancinav. Ao final de 2006, em 28 de dezembro, o Congresso aprovou a Lei $\mathrm{n}^{\mathrm{o}}$ 11.437, que cria o Fundo Setorial do Audiovisual (FSA), que foi regulamentado um ano depois, em 12 de dezembro de 2007, pelo Decreto $\mathrm{n}^{\mathbf{0}}$ 6.299. O Governo abdicou do desejo de ampliar o mercado para novos participantes e abriu mão de regular o setor, dando espaço para produções regionais e independentes.

\subsection{As rádios comunitárias}

Embora as rádios comunitárias estivessem convivendo com a Lei $\mathrm{n}^{\circ}$ 9.612/98, criada no governo de Fernando Henrique para regulamentar o setor, a insatisfação ainda era muito grande. Havia uma expectativa com o governo Lula de que novas mudanças fossem feitas, uma vez que os movimentos sociais sempre viram nas rádios um mecanismo fundamental de participação popular, o que deve ser bem visto num Governo de cunho social, mas o desapontamento foi geral nos dois primeiros mandatos do PT.

Havia a esperança de que no seu Governo a legislação fosse revista e que as perseguições às rádios comunitárias, confundidas propositadamente com as rádios piratas, tivessem fim. Mas a perseguição e repressão até superior continuaram no governo de Fernando Henrique e esse segmento ainda luta para que as proposições aprovadas na Confecom sejam colocadas em prática, como a inclusão da participação das rádios comunitárias na verba publicitária federal, além da instalação de novos canais para o setor. ${ }^{48}$

Em outubro de 2011, depois de muita polêmica e pressão, foi baixada uma portaria pelo ministro das Comunicações, Paulo Bernardo, na qual ele atualiza alguns procedimentos previstos na legislação de 1998. A Portaria n 462, de 14 de outubro de 2011, regulamenta e agiliza alguns procedimentos da Lei $\mathrm{n}^{\circ}$ 9.612, que regia o setor desde 1998. Essa lei era considerada excludente pelos representantes das entidades que defendem o segmento, e muito burocrática. A Portaria de 2011, que é a mais recente, ainda não é a ideal, apesar de atender algumas demandas do setor, e ainda mantém o impedimento para que as rádios comunitárias

\footnotetext{
${ }^{48}$ Durante a Conferência Nacional de Comunicação (Confecom), segundo José Sóter, da Abraço, foi feito um acordo entre o governo Lula e o setor, que previa a instalação de, no mínimo, três canais na faixa de $88 \mathrm{MHZ}$ a 108 MHZ, e inclusão da participação das rádios e TVs comunitárias nas verbas federais.
} 
sejam financiadas por publicidade, bem como as privadas, mantendo o instituto do chamado apoio cultural. $^{49}$

Uma das mudanças que essa portaria trouxe foi sobre o critério de desempate no processo de outorga. A norma anterior determinava, como primeiro critério, que a vencedora seria a que tivesse o maior número de apoio de pessoas físicas e jurídicas. A norma atual determina que prevaleça o número de manifestações de apoio de entidades comunitárias ou associativas, a área de prestação do serviço, constituídas há menos de 2 anos, e também o número de pessoas. A ideia era de que essa portaria desse mais agilidade à tramitação dos processos de outorga de novas emissoras, junto ao Ministério das Comunicações, o que, na prática, acabou não acontecendo.

Apesar de a portaria ter estabelecido mecanismos mais claros e objetivos para a criação e legalização das rádios comunitárias, não inovou em relação aos prazos para a obtenção da outorga e, por si só, não provocou o desengavetamento de processos de legalização que se encontram esquecidos no Ministério das Comunicações. A portaria institucionalizou a lógica dos Planos Nacionais de Outorga, cujo calendário tem de ser divulgado com antecedência, e prevê que as cidades onde não tenha nenhuma rádio comunitária ganhem prioridade.

A atual legislação está longe de atender às reivindicações do setor, a entidade que reúne as rádios comunitárias, a Abraço, lançou, no início de maio de 2014, nova campanha para pressionar o Congresso Nacional a votar mudanças na Lei $\mathrm{n}^{\circ}$ 9.612/98 ou criar uma nova, de iniciativa popular. Segundo matéria publicada no site da entidade,

o movimento das rádios comunitárias, capitaneadas pela Associação Brasileira de Radiodifusão Comunitária (Abraço), vem lutando para transformar a Lei $\mathrm{n}^{\circ}$ 9.612/98 em uma lei que seja fomentadora da democratização da comunicação no País, a partir do fortalecimento como órgão local de comunicação radiofônica, para promover o desenvolvimento sustentável local (ABRAÇO, 2014). ${ }^{50}$

A entidade está promovendo uma campanha para arrecadar assinaturas, por meio das mais de cinco mil emissoras comunitárias autorizadas, para forçar o Parlamento a promover

\footnotetext{
${ }^{49}$ Segundo a lei, apoio cultural é a forma de patrocínio limitada à divulgação de mensagens institucionais, para pagamento dos custos relativos à transmissão da programação ou de um programa específico em que não podem ser propagados bens, produtos, preços, condições de pagamento, ofertas, vantagens e serviços que, por si só, promovam a pessoa jurídica patrocinadora, sendo permitida a veiculação do nome, endereços físico e eletrônico, e telefone do patrocinador situado na área de execução do serviço.

${ }^{50}$ Uma torcida e muitas vozes pela democratização da mídia. Abraço, 2014. Disponível em:

<http://www.abraconacional.org/abraco-promove-acao-por-uma-nova-lei-de〉.
} 
as mudanças desejadas pelo segmento. A ideia é que cada rádio consiga 300 assinaturas e que se consiga um milhão e trezentas mil assinaturas, exigidas pelo Congresso Nacional, para acatar uma proposta de iniciativa popular, ou seja, é a sociedade civil se organizando para obter mudanças que fortaleçam a democracia dos meios de comunicação.

Para os membros da Abraço, que tiveram participação expressiva na Confecom, são muitos os obstáculos que o movimento de rádios comunitárias no Brasil tem de enfrentar.

Vários projetos de lei já foram apresentados, comissões de trabalho formadas, mas são mais de 12 anos sem que nenhum avanço substancial tenha sido obtido, fundamentalmente, porque os donos da mídia comercial conseguem impor derrotas a qualquer tentativa de democratizar os meios de comunicação no País. Eles têm a seu favor o próprio Governo federal e segmentos majoritários do Congresso Nacional (PERUZZO, 2010, p. 8).

A prática desenvolvida pelas rádios comunitárias

tiveram início no contexto das ações dos movimentos sociais, das associações comunitárias e de setores progressistas de igrejas cristãs num processo de busca de soluções aos graves problemas sociais existentes e de mobilização social em torno de lutas para se restabelecer a democracia, após mais de duas décadas da ditadura militar que se instaurou no País em 1964 (PERUZZO, 2010, p. 9).

Todavia, observa, "aos poucos outros atores sociais foram se apropriando do espectro radiofônico, o que tornou o segmento comunitário mais confuso e diversificado" (PERUZZO, 2010, p. 4). Mas a rádio comunitária, que neste início do século XXI incorpora com naturalidade a tecnologia de transmissão em frequência modulada e se inclui de forma crescente na internet tanto na modalidade webrádio (netradio - emissoras que irradiam a partir do dial, mas que também estão online) como nas rádios virtuais (webcasters ou internet-only que existem apenas no ciberespaço) não acabou com a rádio-poste ou de altofalante, batizada carinhosamente pelos ativistas de rádio do povo, ou seja, a única a que a população tem acesso e que maneja segundo seus próprios critérios.

Esta modalidade de rádio comunitária continua desempenhando papel informativo e educativo relevante em muitas regiões do Brasil, um país de contrastes. Em determinadas áreas, o alto-falante continua sendo um meio de comunicação viável e funcional, para suprir as necessidades comunicacionais de cada localidade. Em muitos municípios brasileiros não há, sequer, uma emissora de rádio local ou comunitária. As rádios comerciais que ali são alcançadas e ouvidas pela população levam programações produzidas nas capitais ou nas cidades mais importantes da 
redondeza, que privilegiam temas e interesses dessa realidade mais distante e, portanto, não possuem vínculo local e, se existir, é extremamente tênue. Tal situação ajuda a explicar a importância que as rádios comunitárias passam a ter no País desde a última década do século XX (PERUZZO, 2010, p. 4).

O que faz falta é exatamente uma legislação que não oprima esse tipo de rádio e que crie condições para que ele possa continuar a existir. "A rádio comunitária, tal como foi idealizada pela sociedade civil, regulamentada por força da Lei $\mathrm{n}^{\circ}$ 9.612/98 e decretos subsequentes, não tem finalidade comercial e destina-se a suprir necessidades de expressão de comunidades e grupos sociais organizados, visando promover o desenvolvimento social", reconhece Peruzzo (2010).

Porém, ressalta a pesquisadora,

há aquelas apropriadas por indivíduos interessados em tê-las como fonte de renda (negócio comercial) ou outros tipos de articulações político-partidárias (político-eleitoral) ou religiosa (conscientização, promoção social ou proselitismo de igrejas, conforme o caso). Essa situação provoca controvérsias, distorções e incompreensões no segmento comunitário de rádio no País (PERUZZO, 2010).

Peruzzo (2010) também explica em seu estudo as distorções que existem no setor e que acabam gerando grande instabilidade no meio.

\begin{abstract}
A lei de radiodifusão comunitária é a única que permite a transmissão em baixa potência e a primeira que acena com possibilidades (mesmo que limitadas) de democratização do espectro radiofônico, por essa razão, muitos microempresários e outros grupos se valem dessa prerrogativa para montar "sua" rádio comunitária, o que prejudica o movimento como um todo, pois muitas dessas emissoras descaracterizam os aspectos comunitaristas (PERUZZO, 2010, p.5).
\end{abstract}

Há, por exemplo, emissoras que recebem autorização para funcionar como comunitárias, mas que, de fato, atuam como emissoras comerciais e a serviço de interesses políticos e econômicos de seus donos e/ou de grupos políticos, no exercício do poder local, além de outras de cunho religioso tradicional e sem preocupação com o desenvolvimento comunitário. “Ambos os modelos, embora entre eles haja rádios que prestam serviços de interesse público em suas localidades, contribuem para gerar controvérsias e transformar o setor num campo de incompreensões e conflitos" (PERUZZO, 2010). 
Em função de situações dessa natureza, o setor da mídia comercial se vale desse tipo de distorção para divulgar campanhas difamatórias contra as rádios comunitárias, “taxando-as indiscriminadamente de piratas e clandestinas, o que prejudica a assimilação do seu real papel”. No tocante à legalização dessas rádios, segundo informações do próprio setor, existe grande distância entre a teoria e a prática. Enquanto no Ministério das Comunicações a alegação é de que a autorização de funcionamento é obtida em dois meses, o setor assegura que os processos podem durar anos ou, muitas vezes, serem negados sem nenhuma justificativa objetiva. Ou seja, esse segmento também é vítima da ausência de uma regulação que leve em conta a função social da comunicação.

\subsection{As emissoras de televisão}

Em 2005, surgiu a expectativa de mudança para as emissoras de televisão, especialmente para pequenos municípios - que foi o Decreto $\mathrm{n}^{\circ} 5.371$ que regulamentou as Retransmissoras de TV Institucionais (RTVIs). Segundo o Observatório da Imprensa, "elas representavam uma excelente oportunidade para o poder municipal se tornar retransmissor de emissoras de TV do campo público e também produtor de conteúdo.” Esse decreto autorizava o uso da TV a cabo, pelas prefeituras, de até $15 \%$ do tempo total de transmissão.

O decreto foi bem recebido pelas entidades e celebrado pelas prefeituras e por todos que defendiam o fortalecimento da televisão pública. Além de a TV a cabo não chegar a todos os municípios do País e ser um serviço caro, as operadoras não eram obrigadas a transmitir canais comunitários nem tampouco as atividades das câmaras de vereadores. A ideia era tão boa que as prefeituras já viam nessa oportunidade uma chance para ganhos publicitários com a geração de conteúdo local.

Mas a reação dos poderosos grupos privados de radiodifusão veio rápida e a resposta da presidência da República não demorou. Menos de dois meses depois da assinatura do Decreto $\mathrm{n}^{\mathrm{o}}$ 5.371, o Executivo voltou atrás e baixou o Decreto $\mathrm{n}^{\circ} 5.413$, de 6 abril de 2005, extinguindo de uma vez por todas as RTVIs.

Só em 2011 é que, finalmente, foi aprovada a Lei $n^{\circ}$ 12.485/11, conhecida como ex-PL $\mathrm{n}^{\circ} 29$, posteriormente PLC $\mathrm{n}^{\circ} 116$, responsável pela criação de cotas para a produção e distribuição de conteúdo nacional e veiculação de publicidade na TV paga, entre outras determinações. A lei da TV paga foi discutida durante 5 anos e conseguiu estabelecer uma cota mínima, de apenas $2 \%$ para a obrigatoriedade de exibição da produção nacional, o que 
significa apenas 30 minutos por dia de conteúdo nacional. Em países avançados como a França e a Espanha, essa cota é de $40 \%$.

Segundo a diretora executiva do Sindicato da Indústria Audiovisual do Estado de São Paulo (Siaesp), Débora Ivanov:

Se nós dividirmos essas cotas pelos dias da semana, três horas e meia por semana, a cota é de apenas 30 minutos por dia de conteúdo nacional e somente a metade dessa cota é dedicada à produção independente, isto é, 15 minutos (1\%). Essa porcentagem diminui se a gente levar em conta que também valem para as cotas as repetições da programação (IVANOV, 2013). ${ }^{51}$

Apesar de a cota ser pequena, Ivanov (2013) ressalta que "elas são importantes para a sociedade e razoáveis para as programadoras e para os canais", além disso, a programação foi bem-aceita pelo público, garantiu.

\subsection{TV digital}

Embora tenha havido intenso debate sobre a escolha de modelo de TV digital que seria implantado no Brasil, com a participação direta de representantes da sociedade civil, o resultado acabou não agradando ao movimento social. Em 26 de novembro de 2003, foi baixado o Decreto $n^{\circ} 4.901$ que criou o Sistema Brasileiro de Televisão Digital (SBTVD) constituído de um comitê consultivo, com ampla representação social. Essa escolha foi aceita e há entendimento de que foi positiva.

Em julho de 2005, quando o então senador Hélio Costa (PMDB/MG) foi escolhido para ministro das Comunicações, tratou logo de deixar evidenciado seu perfil controlador e pouco dado a debates. Aos poucos, o comitê consultivo foi sendo esvaziado e ficou à margem do próprio Ministério das Comunicações. Os representantes da sociedade civil perderam voz no conselho e, ao final, não tinham mais nenhuma interferência.

Consequentemente, o País teria de adotar outro modelo e a entrada de uma tecnologia tão avançada como a da TV digital teria mesmo que ocorrer. Segundo especialistas da área, o modelo japonês - desenvolvido depois do americano e do europeu - é, sem dúvida, o mais avançado, e se adapta bem às condições brasileiras tanto econômicas como geográficas.

\footnotetext{
51 Ivanov, Débora. Disponível em: $<$ http://www.stf.jus.br/portal/cms/verNoticiaDetalhe.asp?idConteudo= 231839>.
} 
A discussão e a crítica que decorreram dessa escolha foram em face do já velho debate sobre que segmento da sociedade o Governo quis priorizar com sua decisão e quais os que foram "esquecidos" pelo Poder Executivo. O padrão japonês privilegia a alta definição de imagem e de som, assim como a mobilidade/portabilidade, isto é, seu sinal pode ser recebido em dispositivos móveis como $i$-pods e celulares. O europeu privilegia a diversidade de canais, a multiprogramação e a interatividade, e permite ao telespectador navegar em telas de informação e fazer escolhas, tal como na internet.

Mas o que pesou, de fato, na decisão foi outra funcionalidade bastante conveniente para as emissoras de televisão, pois o padrão japonês permite que as emissoras transmitam diretamente a programação para os celulares, sem que tenha que passar pelas redes de telecomunicação. As próprias emissoras é que fazem o sinal chegar ao aparelho e não as empresas de telecomunicação. Ou seja, as emissoras detêm o controle exclusivo sobre o mercado. Com essa opção, as empresas de telefonia ficaram de fora e os tradicionais donos das emissoras de TV conseguiram evitar que o número de concessionárias de televisão no País fosse ampliado.

\subsection{Empresa Brasil de Comunicação (EBC)}

Embora a sociedade civil organizada, que carrega a bandeira pela democratização dos meios de comunicação, tenha muitas queixas de que a maioria das propostas de políticas públicas para os meios não foram atendidas após a Constituição de 1988, é preciso destacar que uma delas foi atendida e representa um avanço importante. Foi a criação, em 2007, da Empresa Brasil de Comunicação (EBC-TV Brasil), resultado da fusão da Radiobrás com a TV Educativa do Rio de Janeiro, mantida pela Associação de Comunicação Educativa RoquettePinto (Acerp), entidade descentralizada do Governo federal, vinculada ao Ministério da Educação

Apesar das críticas que surgiram durante as negociações da legislação e também durante o processo de implantação, a EBC foi criada e institucionalmente é uma emissora pública e não estatal. Segundo Lima (2011), "o processo de consolidação da EBC, que completou o mandato de sua primeira diretoria no final de 2011, amplia a construção e a presença de um sistema público de comunicação no território nacional" (OBSERVATÓRIO DA IMPRENSA, 2011).

O professor Murilo Ramos, que participa do Conselho Curador da EBC e que participou ativamente das discussões públicas da radiodifusão, considera que a criação da 
EBC, por si só, representa um avanço. Entretanto, receia que alguns dos seus vícios de origem possam comprometer sua autonomia como empresa de prestação de serviço público não comercial e não submisso ao Governo. mantido:

O princípio original que norteou a criação da EBC, de acordo com Ramos (2008), foi

A Empresa Brasil de Comunicação (EBC) nasceu em 2008 de antigas aspirações do movimento social pela democratização da comunicação no Brasil, expressas ao longo de décadas por meio de diferentes propostas de organização jurídica, administrativa e de financiamento, mas que mantiveram uma demanda constante: era necessário dotar o País de um sistema de radiodifusão de serviço público, não comercial, capaz de estabelecer um contraste cidadão com as emissoras comerciais hegemônicas (RAMOS, 2008, p. 16).

O que pode ser entendido como um "vício de origem", segundo Ramos (2008), é passível de correção, pois o que incomoda e ameaça a autonomia da TV pública brasileira é sua ligação normativa ao Governo. Essa ligação pode fazer com que a autonomia da EBC dependa mais "mais do arbítrio de quem eventualmente ocupe a Presidência da República e a sua Secretaria de Comunicação Social" do que da força inata do modelo institucional adotado (RAMOS, 2008).

Para ficar mais claro, vale a pena citar a argumentação de Ramos (2008), feita em artigo em que a analisa a criação da EBC e seu modelo de gestão:

$\mathrm{O}$ que deve ser a marca distintiva da $\mathrm{EBC}$ e suas emissoras de rádio e televisão não é, pois, seu caráter público em oposição ao privado, mas, sim, seu caráter estatal, porque nascida das prerrogativas da União, por iniciativa do Poder Executivo. Logo, estatal, sim; pública, por consequência. Mas, jamais governamental, como, aliás, está expresso nos incisos VIII e IX, do art. $2^{\circ}$ da lei, que afirmam a autonomia da EBC em relação ao Governo federal e asseguram a participação da sociedade civil no controle da aplicação dos princípios do sistema público de radiodifusão. Não obstante essa garantia formal de autonomia, e este é o eixo central da análise, é preciso ir mais fundo na letra da lei em busca não só das suas virtudes, que são muitas, mas também dos seus vícios que, embora poucos, podem representar significativa ameaça ao exercício presente e futuro da autonomia pela EBC (RAMOS, 2008, p. 17).

\subsection{Cidadania nos meios}

Merece registro uma rara vitória dos movimentos sociais de intervenção bem-sucedida na programação das emissoras de televisão do País. Quem não se lembra do programa 
“Tardes Quentes"52, do apresentador João Kleber? Em novembro de 2005, a Procuradoria Federal dos Direitos Humanos do Cidadão acusou esse programa de adotar "atitudes claramente depreciativas, preconceituosas e deturpadas de estereótipos de minorias, tais como homossexuais, idosos, mulheres, deficientes físicos e crianças". Em seguida, determinou sua suspensão por dois meses, o que não foi imediatamente obedecido pela Rede TV. O canal foi retirado do ar e a emissora, depois de muita resistência, dispensou o apresentador e retirou definitivamente o programa da sua rede.

Antes da penalidade, o programa liderou por 4 anos o ranking da campanha 'Quem financia a baixaria é contra a cidadania ${ }^{53}$, da Câmara dos Deputados, com 1.211 denúncias entre janeiro e junho de 2005. A iniciativa de buscar a defesa dos direitos das pessoas ofendidas foi das entidades sociais em defesa da democracia, lideradas pelo Fórum Nacional pela Democratização da Comunicação (FNDC):

Foi um fato inédito na sociedade brasileira. Pela primeira vez, agentes sociais interferem em negócios equivocadamente considerados privados. À ação da campanha houve uma reação destemperada de algumas emissoras por meio de seus porta-vozes. Protestaram contra o fato dos anunciantes serem sensibilizados para o problema, entendendo isso como uma intromissão indevida em assuntos privados. A televisão não é um assunto privado. É um serviço público e, como tal, pode e deve receber influxos da sociedade (LEAL, 2007, p.18).

Essa ação, inédita na televisão brasileira, ilustra a necessidade de observatórios de mídia que possam acompanhar, de perto, o que se passa na telinha. Embora não tenha sido anunciada nenhuma nova interferência na programação televisiva, dessa importância, a campanha continua ativa e completou 14 anos de existência.

A campanha "Quem Financia a Baixaria é contra a Cidadania" foi uma experiência que conseguiu romper, ainda que em grau diminuto, as tentativas de impedir a sociedade civil de influenciar na grade televisiva das grandes redes de televisão, que atingem $90 \%$ dos lares brasileiros. Através da constituição da rede de entidades de direitos humanos e outros movimentos sociais, organizamos reações contra as constantes omissões e infringências ao previsto nos arts. 220 a 224 da Carta Magna. As audiências públicas, os seminários realizados na Câmara dos Deputados, nas assembleias legislativas, universidades e organizações não governamentais criaram uma conscientização e consequente mobilização de milhares de cidadãs e

\footnotetext{
${ }^{52}$ Esse programa era veiculado pela TV Record, durante a tarde, e exibia conteúdo de baixo padrão e de forte teor ofensivo às minorias em geral.

${ }^{53}$ A Câmara dos Deputados, por meio da Comissão de Direitos Humanos, assumiu, em 2001, a campanha "Quem financia a baixaria é contra a cidadania", e criou uma Comissão de Acompanhamento da Programação de Televisão (CAP).
} 
cidadãos em favor de mudanças na programação televisiva (FERREIRA, 2013). ${ }^{54}$

A experiência da campanha não poderia ficar de fora deste estudo, uma vez que iniciativas como essa abrem espaço para a participação do cidadão nos meios de comunicação. Nenhum empresário do setor abriu esse tipo de espaço interativo com o espectador, o que só reforça a luta das entidades sociais em defesa da regulação democrática dos meios, que prevê, entre outras coisas, a criação de conselhos e observatórios de mídia que ouçam a opinião do espectador, do ouvinte e do leitor. Essa ideia também fez parte do elenco de sugestões que foi discutido durante a Confecom. Essa trajetória de perdas e ganhos, na batalha por uma mídia mais plural e democrática, teve mais um capítulo com a realização da Conferência Nacional de Comunicação.

\subsection{3 "Festival de Gambiarras" e o clima que antecedeu a Confecom}

O estado caótico em que se encontrava a legislação brasileira no que tange ao campo da comunicação, as mudanças aceleradas no universo da tecnologia e o clamor da sociedade, em plena vigência, de um governo ligado ao partido dos trabalhadores, criaram um ambiente extremamente favorável para que a Confecom finalmente acontecesse.

O jornalista e ex-ministro da Secretaria de Comunicação Social do Governo Lula, Franklin Martins, que trabalhou ativamente para a criação da EBC, e atuou no sentido de viabilizar a Confecom, foi categórico ao afirmar que a legislação do setor é totalmente anárquica e atrasada: "no Brasil, nós vivemos um festival de gambiarras nessa área há muito tempo" (MARTINS, 2014) ${ }^{55}$, criticou. "O Código Geral de Telecomunicação do Brasil, que rege a radiodifusão e parte das telecomunicações, foi promulgado em 1962 e está claramente defasado, ninguém discorda dessa realidade" (Idem, 2014).

Segundo Martins (2013), a regulamentação tem de ser feita, apesar de toda a resistência da mídia. Martins lembrou também que todas as concessões públicas são reguladas pelo Estado, em qualquer país. Essa discussão, na opinião de Martins, "é indispensável para a sobrevivência dos grupos de comunicação que correm o risco de ser

\footnotetext{
${ }^{54}$ Qualidade na TV/10 anos da campanha Quem Financia a Baixaria é contra a Cidadania. Disponível em:<file://C:/Users/P 881962/Downloads/qualidade tv.pdf>.

${ }^{55}$ Franklin Martins. Entrevista concedida ao Observatório da Imprensa, em 25/2/2014. Disponível em: <http://www.observatoriodaimprensa.com.br/videos/view/entrevista_com_franklin_martins >.
} 
'atropelados pela jamanta' - as empresas de telecomunicação e os grandes portais de busca'. A situação afeta a produção de conteúdo e concentra ainda mais o setor, mas não há interesse em discuti-la. "O problema é que no Brasil nós temos a tradição de que sempre que se fala em discussão de alguma coisa que afeta a imprensa, a reação é como se isso fosse um atentado à liberdade de imprensa", criticou Franklin Martins, pois, isso só ocorre por que o setor é altamente concentrado e não quer ir adiante, sendo assim:

O novo marco regulatório é indispensável para a sobrevivência dos grupos de comunicação, que correm o risco de serem "atropelados pela jamanta" as empresas de telecomunicação e os grandes portais de busca. A situação vai afetar a produção de conteúdo e concentrar ainda mais o setor, mas não há interesse em discuti-la, pois a mídia não quer enfrentar a questão (MARTINS, 2014).

Martins (2014) concorda que há deliberada intenção da mídia em provocar confusão sobre a regulação dos meios de comunicação, ao insistir que "controle social” seja censura. "Mas não é toda a imprensa que pensa assim, porque grande parte disso é algo deliberado por parte da grande imprensa, tentando interditar uma discussão", avaliou o ex-ministro. Para Martins, o debate sobre o marco regulatório acaba sendo um debate sobre a imprensa, a indústria de entretenimento e os direitos da população à informação e à pluralidade. "Isso não tem nada a ver com controle de conteúdo porque censura é um controle prévio de conteúdo. Em momento algum [isso] foi proposto. Vem sendo criada uma grande confusão que interdita o debate. Só que isso não vai dar certo, pois a convergência impõe mudanças e isso terá de ser discutido", garantiu o ex-ministro.

Martins (2014) insistiu que a discussão da comunicação deve ser feita sem medo dos fantasmas da censura ou quaisquer outros, inclusive em relação à discussão sobre um novo modelo de imprensa. "Jornalismo comunitário tem uma importância monumental no mundo todo. Jornal escrito, em princípio, é comunitário, é da cidade dele [leitor]. O rádio também é comunitário. Televisão é que é um pouco mais complicado. Quem souber se conectar com isso vai longe. Quem ficar choramingando porque o mundo está mudando e achincalhando quem quer ir para frente, vai ficar para trás”, aposta Martins (2014). Para ele, atualmente, "as TVs e rádios comunitárias são tratadas como se fossem excrescências, mesmo sendo parte importante no processo de comunicação".

O fundamental, na avaliação de Martins (2014), é que a imprensa se conecte ao sinal dos novos tempos e não fique ligada ao passado: 
Quando a imprensa se conecta com o sentimento do tempo que existe na sociedade, e sempre há diversidade, a imprensa cresce, como aconteceu no fim da Ditadura, com boa parte da mídia. Naquele momento, a mídia se conectou com o sentimento da sociedade e depois disso foi o período em que ela mais cresceu (MARTINS, 2014).

Atualmente, salientou, a imprensa vive um mau momento:

A imprensa é algo que é cíclico, não está sempre ladeira abaixo ou sempre subindo a montanha. Eu acho que nós já vivemos momentos bem melhores na nossa imprensa, sob o ponto de vista da qualidade e da pluralidade. Hoje em dia há um pensamento único (Idem, 2014).

"Por que não se pode debater ideias livremente, com posições diferentes?" questionou Martins (2014).

Para o ex-ministro, a imprensa vive um mau momento, não consegue mais surpreender o leitor e todos os comentaristas falam a mesma coisa. "Hoje em dia eu vejo no jornal: todo mundo fala igual, todos os colunistas falam igual. Isso serve para dar aos telespectadores, leitores e ouvintes uma dose diária de fel e ressentimento que a gente tem que entregar, mas isso também demonstra insegurança no debate de ideias" (MARTINS, 2014).

Mas a regulação tem de ser feita, afirma Martins (2014), até por conta da convergência tecnológica. A entrada da internet na comunicação provocou mudanças que não estão sendo acompanhadas e isso acaba funcionando como um elemento de controle e fiscalização. É "como o grilo falante da história" (Idem, 2014). Casos de manipulação da imprensa são desmascarados rapidamente: "a internet é o cidadão entrando e atropelando as instituições que estão estabelecidas. Está sempre, e rapidamente, apontando os erros da imprensa" (MARTINS, 2014), pois

o padrão vigente, onde um núcleo ativo produtor de informação emite a mensagem para uma massa passiva consumidora, está com os dias contados. Isso acabou. Hoje em dia, mal sai a notícia você já tem um monte de gente na internet discutindo se aquilo é verdadeiro ou não. Os erros da imprensa resistem por pouquíssimo tempo (MARTINS, 2014).

Para entender o contexto midiático e histórico da Confecom é necessário reconstituir, na esfera dos fatos e dos discursos, a trajetória que os dois segmentos-chave desta pesquisa os empresários privados da mídia e as entidades sociais ligadas ao movimento pela democratização dos meios - seguiram ao longo dos últimos 50 anos. A ideia não é uma recuperação linear dos fatos, mas uma busca daqueles mais relevantes, nos quais é possível 
elucidar a posição de cada um e decifrar o discurso construído por ambos diante dos momentos em que questões importantes da comunicação brasileira foram decididas.

Todavia, antes de focar na retrospectiva factual em que esses discursos foram relevantes para atender aos interesses desta pesquisa, que foi a partir do Golpe Militar de 1964, é preciso voltar um pouco mais no desenrolar da história política do País, mais precisamente desde a implantação da República. É que a história do Brasil está de tal forma misturada com a história da imprensa, que é perceptível identificar, sem ser especialista no assunto, uma relação simbiótica entre o Poder político e a mídia, o que por si só constitui elemento estruturante do sistema midiático. Esse perfil, por sua vez, denota traços de uma relação paternalista, viciada e escorada em acordos escusos e trocas de favores pouco republicanos. Mas tudo isso começou lá atrás, não surgiu de um momento para o outro, por essa razão, é fundamental um retorno no tempo.

Entender como se constituiu a mídia brasileira, como ela tem se modificado e como tem modificado a sociedade, especialmente após a internet, foi um desafio nesta pesquisa. Para compreender por que a democracia ainda está tão distante da nossa prática midiática e por que ainda denominamos os proprietários de empresas de comunicação de "coronéis eletrônicos" é preciso, de fato, conhecer a história.

As raízes que podem explicar qual é, de fato, o DNA dessa mídia, que até hoje não abandonou as práticas patrimonialistas herdadas da nossa colonização portuguesa, que insiste em domar sua audiência, que se recusa a crescer democraticamente, estão arraigadas no modelo de desenvolvimento econômico neoliberal, que estabelece elos de promíscua intimidade entre o Poder, a política e a imprensa, dimensões que não podem ser compreendidas isoladamente, conforme Guareschi:

A total ausência de controle da propriedade cruzada dos meios e da formação de redes (de rádio e televisão) deu origem a poderosos oligopólios empresariais multimídia - nacionais, regionais e locais - que exercem seu controle não só sobre a maioria das concessões de radiodifusão como também sobre a mídia impressa (jornais e revistas) e, mais recentemente, sobre os principais provedores da internet (GUARESCHI, 2013, p. 14). 


\section{CAPÍTULO 2}

\section{A CONFECOM}

A Conferência Nacional de Comunicação (Confecom) é resultado da luta das entidades civis que desde antes da Constituinte de 88 começaram a se organizar para levar adiante a bandeira da democratização dos meios de comunicação do país. Este movimento começou quando o FNDC, era ainda a Frente Nacional de Luta por Políticas Democráticas de Comunicação que foi criada em julho de 1984, como foi lembrado no capítulo anterior, que trouxe um pouco do contexto histórico que criou condições para que a Conferência de Comunicação fosse, enfim, convocada e realizada no final de 2009.

A convocação não surgiu do espontaneísmo do Governo de Luís Inácio Lula da Silva de querer agradar a sua militância, que compõe as fileiras do movimento, e sim de não poder mais adiar um compromisso que já havia firmado desde 2005, quando o assunto foi o tema principal do encontro Nacional de Direitos Humanos realizado na Câmara dos Deputados, em agosto daquele ano, e que teve o patrocínio do governo. A partir desta data o assunto ficou constante nas conversações entre as entidades, o Congresso Nacional e o Governo.

A Confecom só aconteceu depois de muita pressão dos movimentos sociais e de parte do Partido dos Trabalhadores e de deputados ligados à área. Antes da convocação da Confecom, em Belém, no Fórum Social Mundial, houve um longo caminho que foi palmilhado pelas entidades, associações e pessoas envolvidas com a luta pela democratização dos meios de comunicação no Brasil.

\subsection{A mobilização pré-Confecom}

A pauta da democracia na comunicação começou a ganhar corpo em 2005 quando o assunto foi o tema principal do encontro Nacional de Direitos Humanos ${ }^{56}$. Foi um evento importante da sociedade civil brasileira que contou com participação do Fórum Nacional de entidades de Direitos Humanos, que entrou em articulação com as entidades ligadas à

\footnotetext{
${ }^{56}$ Trata-se do Encontro Nacional de Direitos Humanos - Direito humano à comunicação: um mundo, muitas vozes, realizado nos dias 17 e 18 de agosto de 2005 cujo tema central foi $\mathrm{O}$ direito humano à Comunicação.
} 
comunicação. Essa união de interesses fortaleceu a necessidade de capilarizar essa discussão sobre o direito humano à comunicação, e em face da publicação de 25 anos da publicação do relatório da Comissão $\mathrm{McBride}^{57}$, cresceu a ideia para que o tema O Direito Humano à Comunicação fosse a questão principal do encontro, realmente foi um marco. Segundo o professor e doutor em Comunicação da Universidade de Brasília (UnB), Fernando Paulino ${ }^{58}$, que participou ativamente de todo o processo, "a partir de então se intensificaram as articulações de entidades da sociedade civil em diálogo com o parlamento para buscar a convocação de uma conferência nacional de comunicação".

No relatório ${ }^{59}$ publicado após o encerramento do Encontro, a realização de uma conferência sobre políticas públicas para a Comunicação chegou a ser sugerida entre as ações que teriam que ser implementadas para que o Direito Humano à Comunicação fosse, de fato, garantido à sociedade brasileira, como destaca o documento:

Como garantir a participação efetiva por parte de todos os elementos da sociedade civil na preparação, implementação e avaliação de estruturas e políticas públicas de comunicação? Consultas e audiências públicas realizadas pelas instâncias do Estado, conferências locais, regionais e nacionais de comunicação, tendo a sociedade civil como principal protagonista, são algumas propostas que apontam nesse caminho. ${ }^{60}$

Após este evento de 2005 o assunto não saiu mais da pauta dos movimentos sociais. Em outubro de 2006 aconteceu a Plenária do Fórum Nacional pela Democratização da Comunicação, e em 2007 começou a articulação para a criação de uma comissão nacional pró-conferência, que foi criada durante o encontro promovido pelas comissões de Ciência, Tecnologia, Comunicação e Informática; e de Direitos Humanos da Câmara; e de Direitos Humanos e Legislação participativa do Senado que foi denominado "Encontro Nacional de Comunicação - Na luta por democracia e Direitos Humanos. Este seminário foi realizado no

\footnotetext{
${ }^{57}$ O Relatório McBride - Um mundo e Muitas Vozes - lançado em 1980 pela Unesco foi o primeiro documento oficial de um organismo multilateral a reconhecer o grave desequilíbrio no fluxo mundial de informação e a lançar ideias para mudar esta situação.

${ }_{58}^{58}$ Fernando Paulino concedeu entrevista a esta pesquisadora em 23/10/14.

${ }^{59}$ Relatório final do Encontro Nacional de Direitos Humanos está Disponível em:

<http://bd.camara.gov.br/bd/handle/bdcamara/1943>.

${ }^{60}$ Relatório final do Encontro Nacional de Direitos Humanos realizado em agosto de 2005. Disponível em: <http://bd.camara.gov.br/bd/handle/bdcamara/1943>.
} 
auditório Nereu Ramos da Câmara dos Deputados entre os dias 21 e 22 de junho de 2007. O objetivo já era definir os temas e a estrutura organizacional para a conferência. ${ }^{61}$

As deputadas Maria do Carmo Lara (PT-MG) e Luiza Erundina (PSB-SP) e o deputado Jorge Bittar (PT-RJ), que eram alguns dos parlamentares ligados à causa da democracia dos meios, foram os autores do requerimento para a participação da Comissão de Ciência e Tecnologia no seminário que seria promovido pelo Senado. Na ocasião alguns jornais publicaram os argumentos defendidos por estes parlamentares:

Eles argumentaram que o objetivo do encontro deveria ser mais amplo e reunir representantes do Poder Executivo; da sociedade civil organizada; das empresas de comunicação e telecomunicações; dos agentes reguladores e outras pessoas envolvidas na elaboração do novo modelo de comunicação social eletrônica. ${ }^{62}$

Ao final do seminário foi elaborada uma carta aberta ao presidente da República intitulada - Por uma legítima e democrática Conferência Nacional de Comunicações - que, entre outras coisas, ressaltava a importância da comunicação na formação de valores e opiniões, no fomento e na produção das culturas e nas relações de poder e, por isso, a necessidade de uma reflexão sobre os meios, a cadeia produtiva e os sistemas; as diversas formas pelas quais o conteúdo, enquanto conhecimento, cultura, lazer e informação inclusive comercial -, são produzidos, difundidos, assimilados e usufruídos pela população; daí a necessidade de corrigir algumas distorções históricas no setor.

A Comissão Nacional Pró-Conferência (CNPC) foi a mola propulsora para que a conferência acontecesse, ela foi composta pelas seguintes entidades:

- Associação Brasileira de Canais Comunitários (ABCCOM),

- Associação Brasileira das Emissoras Públicas, Educativas e Culturais (ABEPEC),

- Associação Brasileira de Gays, Lésbicas, Bissexuais, Travestis e Transexuais (ABGLT),

- Associação Brasileira de Imprensa (ABI),

\footnotetext{
${ }^{61}$ Encontro discutirá temas para a conferência de comunicação. Disponível em: <http://www2.camara.leg.br/documentos-e-pesquisa/fiquePorDentro/noticias/encontro-discutira-temas-paraconferencia-de-comunicacao $>$.

${ }^{62}$ Encontro discutirá temas para a Conferência de Comunicação. Disponível em: $<$ http://www2.camara.leg.br/documentos-e-pesquisa/fiquePorDentro/noticias/encontro-discutira-temas-paraconferencia-de-comunicacao $>$.
} 
- Associação Brasileira de ONGs (ABONG),

- Associação Brasileira de Radiodifusão Comunitária (ABRAÇO NACIONAL),

- Associação Brasileira de TV Universitária (ABTU)

- Associação Mundial Das Rádios Comunitárias (AMARC BRASIL)

- Agência de Notícias dos Direitos da Infância (ANDI)

- Associação das Rádios Públicas do Brasil (ARPUB)

- Associação Brasileira de TVs e Rádios Legislativas (ASTRAL), Campanha - Quem financia a baixaria é contra a cidadania

- Coletivo de Entidades Negras (CEN)

- Conselho Federal de Psicologia (CFP)

- Conselho Federal De Profissionais de Relações Públicas (CONFERP)

- Conselho Nacional de Umbanda (CONUB)

- Central Única dos Trabalhadores (CUT)

- Executiva Nacional dos Estudantes de Comunicação Social (ENECOS),

- Federação Nacional dos Jornalistas (FENAJ)

- Federação Nacional dos Servidores do Judiciário e do Ministério Público Federal (FENAJUFE)

- Federação Interestadual dos Trabalhadores em Empresas de Rádio e Televisão (FITERT)

- Federação Interestadual dos Trabalhadores em Telecomunicações (FITTEL)

- $\quad$ Fórum de Mídia Livre (FML),

- Fórum Nacional pela Democratização da Comunicação (FNDC)

- Fórum de Entidades Nacionais de Direitos Humanos (FNDH)

- Instituto Brasileiro de Defesa do Consumidor (IDEC)

- Instituto de Estudos Socioeconômicos (INESC)

- Intervozes - Coletivo Brasil de Comunicação Social

- Laboratório de Políticas de Comunicação da Universidade de Brasília (LaPComUnB)

- Marcha Mundial de Mulheres (MMM)

- Movimento Nacional de Direitos Humanos (MNDH)

- Movimento Negro Unificado (MNU)

- Movimento dos Trabalhadores Rurais Sem Terra (MST) 
- Ordem dos Advogados do Brasil (OAB)

- Procuradoria Federal dos Direitos do Cidadão - Ministério Público Federal (PFDC)

- Rede Nacional dos Observatórios da Imprensa (RENOI)

- Rede de Informações para o Terceiro Setor (RITS)

- União Nacional dos Estudantes (UNE)

- Comissão de Direitos Humanos e Minorias da Câmara dos Deputados (CDHM),

- Comissão de Ciência e Tecnologia, Comunicação e Informática da Câmara dos Deputados (CCTCI)

- Comissão de Legislação Participativa da Câmara dos Deputados (CLP).

A capilarização pretendida pelos organizadores acabou acontecendo, na prática, em função dessas outras entidades que não são do campo da comunicação, mas guardam uma importante interface com o setor. Aos poucos o tema acabou ganhando espaço e fazendo parte da agenda de todas essas associações. Segundo o professor Paulino,

Surgiu com mais impulso a participação do grupo GLBT, as entidades do movimento negro, movimento de mulheres, uma série de agentes importantes da sociedade civil começaram a se envolver nessas discussões para além do comum. E não apenas estudantes de comunicação e profissionais, foi além e chegou até os empresários e outros agentes já citados, que promoveram um ano muito rico em debates (PAULINO, 2014)

Durante 2007 e 2008 o movimento se intensificou bastante no Brasil como um todo. A partir da criação da comissão nacional pró-Confecom, em 2007, surgiram comissões estaduais e a distrital pró Conferência de Comunicação o que fez com que em todo o país houvesse atividades, eventos, seminários, encontros. Um importante estímulo - que foi um grande marco para que a Confecom acontecesse - foi a participação de entidades de fora do campo da Comunicação nessas discussões, como foi colocado por Paulino e reforçado por Jonas Valente, do Coletivo Intervozes. A Comissão Nacional Pró Conferência (CNPC) passou a se reunir, quinzenalmente, lá na Câmara dos Deputados estabelecendo encontros com a Fenaj (Federação Nacional dos Jornalistas), o FNDC (Fórum Nacional em Defesa da Democratização) e outras entidades com os parlamentares envolvidos, como a deputada Luíza Erundina, (VALENTE, 2013 apud SOUSA, 2013),

Valente explicou que desde 2007, a Comissão Nacional Pró-Conferência já fazia pressão junto ao Governo Federal, especialmente sobre o Ministério das Comunicações e a 
Secretaria Geral da Presidência da República, órgão responsável pela convocatória e organização de grande parte das conferências nacionais.

Ao longo do ano de 2008, destacou Valente, a gente também pressionava o governo, mas não via abertura. O governo não dava sinalização que iria fazer a conferência. No fim de 2008, porém, teve um fato que foi um marco importante para que a Conferência acontecesse. A gente realizou um evento na Câmara, com o plenário lotado, em que a gente chama o Marcelo Bechara (à época, Consultor Jurídico do Ministério das Comunicações) para dentro do processo e depois ele se tornou o Presidente da Comissão Organizadora Nacional da $1^{\text {a }}$ Confecom. (VALENTE, 2013)

Após essa articulação a pauta da Conferência sai do Minicom (Ministério das Comunicações) e vai para dentro do Palácio do Planalto, onde estava prevista uma reunião depois da realização do Fórum Social Mundial para tratar do assunto. Mas, inesperadamente, durante o Fórum Mundial, no início de 2009 em Belém (PA), a Conferência foi convocada e os acontecimentos se precipitaram.

Mas ele (o então presidente Lula) não fez essa convocação do nada, destacou o professor Fernando Paulino, até porque, além da pressão que havia dos movimentos sociais, a deputada Luiza Erundina teve a preocupação de colocar no orçamento em 2008 a verba para a conferência, se não, não teria como ela acontecer, isso foi determinante. Se não tivesse orçamento não tinha como a Conferência acontecer, houve uma necessidade grande de recursos para que ela fosse realizada (PAULINO, 2014).

Jonas Valente também avalia que a convocação da conferência em Belém foi inesperada:

Por algum razão, que a gente não sabe qual é, o Lula, ao responder uma pergunta do Fórum Social Mundial 2009, fala que entre os projetos do governo na área da comunicação tem o PL $29^{63}$ e a Conferência de Comunicação. E aquilo é comemorado pelas organizações da sociedade civil, que entendem aquilo com uma sinalização de - vamos fazer (VALENTE, 2013).

\footnotetext{
${ }^{63}$ O PL 29/07 é de autoria do deputado Paulo Bornhausen (DEM-SC) e ele propõe que as empresas de telefonia fixa e móvel também tenham o direito de produzir e distribuir conteúdo eletrônico, assim como as empresas de comunicação tradicionais.
} 
Embora o Partido dos Trabalhadores tivesse em seu programa a pauta da democratização dos meios, o assunto não era um tema pacífico, havia divergências dentro do partido. Segundo Paulino, "houve muita pressão dentro do PT, onde não havia um consenso, uma parte queria que a Conferência acontecesse, e outra não". Houve pressão sobre a Casa Civil da Presidência da República também, acrescentou o professor, e neste meio tempo já aconteciam reuniões variadas, com o Secretário da Comunicação do presidente Lula, Franklin Martins quando foram feitas mais pressões para que a Conferência fosse convocada.

Por fim, o que prevaleceu dentro do PT é que,

se houvesse o fortalecimento dessa onda pró-conferência o partido e o Governo poderiam se ambientar nessa reivindicação da sociedade e com isso diminuir a tensão perante os empresários para a realização de uma conferência como essa que causava bastante ruído entre o setor (PAULINO, 2014).

Esta evolução gradativa do processo - que desaguou na convocação da Confecom foi fundamental para que ela acontecesse. Octavio Pieranti, que atuou como representante do Ministério da Cultura na Comissão Organizadora Nacional da Confecom, compartilha desta percepção. Ele confirma que, bem antes da convocação oficial, dentro do Governo, a conferência passa a ser a grande pauta já a partir de meados de 2008.

Esse tema começa a ganhar força dentro do Governo em face das pressões da sociedade civil, "visto que - as entidades representantes da sociedade civil tinham todos os elementos jurídicos e técnicos para cobrar uma conferência de comunicação, porque ela não tinha existido até então" (PIERANTI apud SOUSA, 2013). Todos os demais setores incluídos no Título VIII - Da Ordem Social, na Constituição Federal de 1988 já haviam tido as suas conferências nacionais, como é o caso da saúde, educação, minorias, direitos humanos e meio ambiente.

o processo que culminou na convocação da Confecom se mostrou diferente da maioria de movimentos similares que levaram à realização de conferências em outras áreas de interesse, normalmente capitaneados por órgãos do Poder Executivo. Embora tenha havido importante contribuição das Comissões de Direitos Humanos e Minorias e de Ciência e Tecnologia, Comunicação e Informática da Câmara dos Deputados, o protagonismo na articulação da Comissão Nacional Pró- Conferência - etapa importante desse processo -, deve ser creditado à sociedade civil não - empresarial, em particular às entidades ligadas à democratização da Comunicação (SOUSA, 2014). 
Do lado do Congresso a movimentação também começou a crescer a partir de 2008. Os parlamentares, capitaneados pela deputada Luíza Erundina, foram os responsáveis pela convocação de uma conferência nacional para o setor das Comunicações, conforme informa o site da Comissão Pró-Conferência:

Embora o movimento tenha se organizado como tal, somente há poucos anos, a demanda por uma conferência nacional de comunicação já existe há tempos, a partir da análise de que a comunicação precisa estabelecer mecanismos democráticos de formulação, monitoramento e acompanhamento das políticas públicas para o setor. Em um quadro de ausência de um marco regulatório consistente, a construção das poucas políticas de comunicação existentes se dá, atualmente, sem a efetiva participação da sociedade. ${ }^{64}$

Essa Comissão Pró-Conferência também contou com o empenho do Conselho Federal de Psicologia e com a Associação Brasileira de Radiodifusão Comunitária (Abraço), além do coletivo Intervozes, do FNDC e outras entidades sindicais e sociais. Segundo documento do Instituto Patrícia Galvão - Comunicação e Mídia,

havia uma expectativa histórica dos movimentos sociais com relação à realização de uma conferência de Comunicação, para promover amplo debate público sobre temas como o controle social dos meios de radiodifusão nas mãos de poucos grupos e a politização da radiodifusão no País. ${ }^{65}$

Presente em 22 estados brasileiros, esse movimento - desencadeado pela PróConferência - teve papel fundamental na articulação da sociedade, para a construção do processo da Confecom.

Agregando todas as entidades de classe trabalhadoras, e mais 30 outras civis, a comissão foi responsável pela mobilização para pressionar o Governo a convocar a Conferência, além de preparar, por meio de seminários e outras atividades, os movimentos sociais para a I Confecom. Além das organizações que tinham a democratização como principal bandeira de luta, essa comissão congregou outros "intelectuais coletivos" dos movimentos estudantil, negro, LGBT e de outras áreas como a Psicologia e a Advocacia (AGOSTINHO, 2011, p. 9). ${ }^{66}$

\footnotetext{
${ }^{64}$ Sociedade civil em preparação para a Conferência Nacional de Comunicação Disponível em: $<$ http://proconferencia.org.br.quemsomos>.

${ }^{65}$ O Instituto Patrícia Galvão foi a primeira organização feminista no País, criada em 2001, sem fins lucrativos, para atuar nos campos do Direito à Comunicação e Direito das Mulheres.

${ }^{66}$ Niep Marx. Marx e o Marxismo 2011: teoria e prática. Universidade Federal Fluminense. Niterói, RJ. 28/11/2011 a 1/12/2011.
} 
Muitas das entidades que compuseram a CNPC participaram de momentos importantes e decisivos em relação à política de comunicação no Brasil. Entre eles, pode-se destacar a participação da Fenaj, na época da Assembleia Nacional Constituinte para a inclusão de artigos constitucionais com vistas à democratização da comunicação, e a atuação do Fórum Nacional pela Democratização da Comunicação (FNDC) para a aprovação, pelo Congresso, de uma lei regulamentando a televisão a cabo no Brasil e que protagonizou os momentos seguintes de reivindicação e articulação da Confecom nos estados e em nível nacional (SOUSA, 2014)

\subsection{O anúncio da convocação da Confecom}

A formulação das políticas públicas para a Comunicação, naquela época, estava diluída entre a Casa Civil e o Ministério das Comunicações, bem como as relações com as empresas de mídia, inclusive a distribuição de recursos publicitários. Já o serviço de assessoria de imprensa estava diluído entre a Secretaria de Comunicação e a Secretaria de Imprensa, vinculado ao gabinete do Presidente. Havia forte pressão das entidades para que as questões da mídia fossem discutidas com a sociedade e em fórum adequado. Quando ocorreu o Fórum Social Mundial de Belém, de 2009, era intensa a pressão pela convocação da Conferência, mas ainda não havia nada acertado, e tampouco a certeza de que a Conferência seria mesmo anunciada e convocada pelo então presidente Lula.

Até para os envolvidos bem de perto com o assunto, não ficou claro, até hoje, porque a Confecom foi convocada no dia 26 de janeiro de 2009 durante a realização do Fórum Mundial. Muitas das pessoas ouvidas pela pesquisa sugeriram que só mesmo o ex-presidente Lula poderia esclarecer.

Segundo relato do jornalista e blogueiro Renato Rovai ${ }^{67}$, que participou do Fórum em Belém, o clima era de muita expectativa. Ele conta que, pouco antes da abertura do evento, encontrou um assessor da Presidência da República para assuntos ligados à comunicação (cujo nome ele não revelou) e que este lhe confidenciara que "no "saco" de bondades que o Governo trazia para aquele fórum, a novidade era a convocação para a Conferência Nacional de Comunicação, mas era preciso aguardar confirmação".

No discurso de abertura do presidente Lula, em que diversos assuntos ligados ao avanço da democracia na América Latina e no Brasil foram lembrados, nada foi anunciado

\footnotetext{
${ }^{67}$ Renato Rovai esteve no Fórum de Belém e é jornalista e editor da revista Fórum.
} 
sobre a Confecom. No final do encontro, coube ao ministro Luiz Dulci, então Ministro-Chefe da Secretaria-Geral da Presidência, numa das atividades do Fórum, confirmar que "entre as muitas conferências que o Governo convocaria em 2009 estava a da Comunicação". Pouco depois, o assessor de Lula, frei Betto, em palestra inflamada, reafirmou a convocação.

De acordo com Rovai (2009), que esteve presente ao evento, "entre os militantes do setor, o anúncio foi celebrado como uma grande conquista e alguns diziam frases como "agora tudo mudou". A pauta do movimento pela democratização da comunicação passaria, necessariamente, pela Conferência”. Todavia, o decreto que oficializou a convocação da Confecom só foi baixado 77 dias após o anúncio simbólico, o que, para os representantes dos movimentos, significava "um sinal de quão difíceis seriam as costuras políticas para que a Confecom se tornasse realidade." 68

\subsection{A Confecom é oficialmente convocada}

Finalmente, em 16 de abril de 2009, o Diário Oficial da União publicou o decreto oficializando a convocação da Confecom. Entretanto, o anúncio feito em Belém e a edição do decreto convocatório "não garantiam que a Conferência fosse realizada", pois "havia muita pressão do setor empresarial e demora na votação do regimento interno, o que atrasou as etapas estaduais, municipais e distritais", registrou em seu blog o analista Rafael de Abreu. ${ }^{69}$

Inicialmente, as entidades sociais esperavam que o tema da Conferência fosse apenas sobre a construção de direitos e de cidadania em meio às discussões sobre a democratização da mídia. Porém, em face de pressões dos empresários, os responsáveis por essa decisão, especialmente dentro do Ministério das Comunicações, conseguiram incluir o termo na era digital $^{70}$, para tentar, subliminarmente, acalmar o segmento mais tradicional dos empresários e passar aos movimentos sociais que a ideia era focar os debates apenas e tão somente na mídia desenvolvida pela internet, o que acabou não acontecendo.

Esse detalhe não impediu que a discussão englobasse toda a mídia instituída, independentemente da plataforma. A Portaria $n^{\circ} 185$, de 20 de abril de 2009, com o objetivo de instituir os órgãos do Poder Público e as instituições da sociedade civil que fariam parte da comissão organizadora, seria a responsável por regular e organizar todos os detalhes da Conferência. A composição estabelecida pela portaria foi a seguinte: oito representantes do

\footnotetext{
${ }^{68}$ A Confecom de fato. Disponível em: <www.renatorovai.blogspot.com.br>

${ }^{69}$ A Confecom de fato. Disponível em: <www.rafaeldeabreu.glogspot.com.br>

${ }^{70} \mathrm{O}$ professor Murilo Ramos, no capítulo que trata da apresentação desta pesquisa, dá sua interpretação sobre esta questão.
} 
Executivo, dois do Legislativo e 16 representantes da sociedade civil, divididos em sete entidades dos movimentos sociais, oito do setor privado-comercial e uma da mídia pública. É preciso destacar que para chegar a esses representantes muitos impasses foram gerados, e nenhum dos lados ficou plenamente satisfeito. Segue abaixo a lista dos participantes:

\section{PODER PÚBLICO}

1. Casa Civil da Presidência da República

2. Ministério das Comunicações

3. Ministério da Ciência e Tecnologia

4. Ministério da Cultura

5. Ministério da Educação

6. Ministério da Justiça

7. Secretaria de Comunicação Social da Presidência da República

8. Secretaria-Geral da Presidência da República

9. Senado Federal

10. Câmara dos Deputados

II SOCIEDADE CIVIL

11. ABCCOM - Associação Brasileira de Canais Comunitários

12. ABEPEC - Associação Brasileira das Emissoras Públicas, Educativas e Culturais

13. ABERT - Associação Brasileira de Emissoras de Rádio e Televisão

14. ABRA - Associação Brasileira de Radiodifusores

15. ABRAÇO - Associação Brasileira de Radiodifusão Comunitária

16. ABRANET - Associação Brasileira de Provedores Internet

17. ABTA - Associação Brasileira de TV por Assinatura

18. ADJORI BRASIL - Associação dos Jornais e revistas do interior do Brasil

19. ANER - Associação Nacional de Editores de Revistas

20. ANJ - Associação Nacional de Jornais

21. CUT - Central Única dos Trabalhadores

22. FENAJ - Federação Nacional dos Jornalistas

23. FITERT - Federação Interestadual dos Trabalhadores de Empresas de Radiodifusão e Televisão

24. FNDC - Fórum Nacional pela Democratização da Comunicação

25. INTERVOZES - Coletivo Brasil de Comunicação Social

26. TELEBRASIL - Associação Brasileira de Telecomunicações 
Nota-se que os membros da sociedade civil estão todos juntos, ou seja, não havia ainda a distinção entre sociedade civil empresarial e não empresarial. Os representantes das entidades da sociedade civil que, historicamente, lutam pela democratização dos meios não queriam estar na mesma listagem, todavia, os empresários também tinham razão pois também são representantes da sociedade civil, lembrando que, pelo senso comum - que não está de todo errado - quem não é Governo é sociedade civil.

Logo depois, foi publicada a lista com os nomes dos representantes de todas as entidades e órgãos do Poder Público que foram indicados na Portaria 185 de abril de2009. A Portaria nomeou 81 participantes, pois também incluía os suplentes. Logo depois, saiu a retificação dessa portaria por outra, a Portaria nº 337, que indicou a deputada Luíza Erundina representante da Câmara dos Deputados, o que fortaleceu o nível dos debates.

Nestas reuniões, que aconteciam a cada 15 dias, os participantes debateram com intensidade as normas e detalhes sobre a votação das propostas e de como ficaria definido o Regimento Interno da Conferência, a CON realizou 16 reuniões ao longo de 2009. E por fim, em2 de setembro de 2009, foi publicado, por meio da portaria 667, do Ministério das Comunicações, o Regimento Interno da $1^{\text {a }}$ Confecom. O documento foi complementado, ainda, pela publicação da Resolução $\mathrm{n}^{\circ}$ 1, de 10 de setembro de 2009, que definiu os três eixos temáticos que norteariam os trabalhos da Conferência. O Regimento determinava também 45 temas indicativos a cada eixo temático, cujo detalhamento está em anexo. Os três eixos temáticos definidos foram os seguintes:

\section{I - Produção de Conteúdo \\ II - Meios de Distribuição \\ III - Cidadania: Direitos e Deveres}

As conversações no âmbito da CON já projetavam problemas que viriam a surgir mais tarde. Eram muitos interesses conflitantes e um elenco propostas bem diverso:

já era evidente o cenário de disputa de interesses. "Há um enorme impasse já na comissão, acentuou, a comissão organizadora precisa baixar um regimento estabelecendo como a Conferência será realizada. Os interesses opostos são muito fortes. $\mathrm{O}$ segmento de radiodifusão quer que o regimento definisse a agenda, a pauta da conferência, e queria que isso se resumisse à discussão de regulamentação da internet. $\mathrm{O}$ setor social quer discutir um enorme contencioso do campo da comunicação social, que tem a ver com política de concessão, com regulamentação do conteúdo de rádio e TV nos 
termos da Constituição brasileira, que nunca foi regulamentado (DANTAS). ${ }^{71}$

Os empresários que faziam parte da Comissão começaram a ficar incomodados com os rumos que as decisões com relação ao regimento estavam tomando. Eles temiam que a Conferência aprovasse mudanças que iriam contrariar os interesses do segmento privado de mídia, e que eles não conseguissem o número de delegados que pudesse barrar eventuais propostas nesse sentido.

\subsection{A saída parcial de empresários da Confecom}

Depois de já terem participado de 13 das 16 reuniões oficiais realizadas pela Comissão Organizadora, a maioria dos empresários abandonou o processo de construção da Confecom e optou por não participar da etapa nacional do evento que ocorreria em dezembro de 2009. Quando as discussões estavam mais acirradas com relação ao sistema de votação das propostas e a proporcionalidade dos delegados, seis das oito entidades que representavam os empresários do setor privado de mídia decidiram sair do processo, apesar dos esforços feitos pelos representantes do Governo. São elas, Associação Brasileiras das Emissoras de Rádio e Televisão (Abert), Associação Nacional dos Jornais (ANJ), a Associação Brasileira de Internet (Abranet), Associação Brasileira de TV por Assinatura (ABTA), a Associação dos Jornais e Revistas do Interior do Brasil (Adjori Brasil) e a Associação Nacional dos Editores de Revistas (Aner).

Quem estava acompanhando de perto as reuniões preparatórias da Comissão apostava que os empresários iriam se retirar bem antes da data em que de fato isso aconteceu. Oito dias antes do anúncio da saída, que se deu em 13 de agosto de 2009, os empresários, capitaneados pela Abert, que representa os interesses da TV Globo, em reunião com os representantes do Governo queriam garantias de preservação do sistema de outorgas e respeito aos princípios constitucionais que regem o setor. O Governo atendeu a essas demandas, uma vez que não aprovaria nada que ferisse a Constituição Federal.

\footnotetext{
${ }^{71}$ Rever Política de concessões é prioridade na Confecom. Observatório do Direito à Comunicação. Entrevista com Marcos Dantas, 4/9/2009.
} 
Mas ainda assim, o grupo majoritário de representantes dos empresários estava incomodado com a evolução das conversações. O grupo de ministros que representava o Poder Público na comissão tentava negociar a permanência dos empresários, o impasse girava em torno das definições do Regimento Interno, especialmente com relação à divisão dos delegados e a instituição de um quórum qualificado para a aprovação das propostas consideradas polêmicas.

A divisão do número de delegados por segmento na proporção 40-40-20: 40\% para os empresários, $40 \%$ para sociedade civil não-empresarial e $20 \%$ para o governo deveria ter atendido aos reclamos dos empresários, uma vez que as entidades que representavam o movimento pela democratização da mídia, estavam insatisfeitos com tal divisão, alegando que o setor estaria sub-representado. Essa composição foi durante as conversações e depois da pressão dos empresários, mas ainda assim uma boa parte deles preferiu sai da comissão organizadora e não participar da Confecom.

De acordo com entrevista do representante das empresas de telefonia fixa, José Pauletti $^{72}$, apesar da divisão dos delegados ter atendido á demanda dos empresários, ainda restava a questão do quórum. "Ainda tem a questão do voto qualificado, se é $60 \%$ ou $60 \%$ mais um, mas não é nada incontornável e provavelmente continuaremos dentro da Comissão" (PAULETTI, 2009). Tanto a Abra, que representa a TV Bandeirantes e a Rede TV, como a Telebrás, que representa as empresas de telecomunicações, queriam continuar dentro do processo.

Essa indefinição acabou atrasando a redação do regimento interno da Confecom, que era a condição para o início efetivo do processo e para a realização das etapas estaduais. E logo em seguida, com a saída dos empresários, o regimento ainda sofreu mais atrasos. No dia 11 de agosto, as entidades sociais, presentes na $\mathrm{CON}$, em reunião com os ministros se mostraram insatisfeitas e apresentaram divergências com relação à divisão dos delegados, mas acabaram aceitando a proposta do Governo.

Porém, diversas entidades - que participavam das Comissões Estaduais PróConferência, criticaram essa decisão. A Comissão Pró-Conferência do Rio de Janeiro divulgou nota ${ }^{73}$ em que afirma que a adoção da proporção 40-40-20 - seria aceitar a tese de que eles correspondem à metade de toda a sociedade civil organizada, o que não é verdade. A

\footnotetext{
${ }^{72}$ Entidades empresariais anunciam saída da comissão organizadora nacional. Publicação do Sintel (Sindicato das empresas de telefonia), 11/08/2009. Disponível em: $<$ http://www.sinttelrio.org.br/noticia_sa\%EDda.htm>.

${ }^{73}$ Nota da Comissão RJ Pró-Confecom. Disponível em:

$<$ http://rioproconferencia.wordpress.com/2009/08/19/nota-da-comissao-rj-pro-confecom/>
} 
comissão defendeu na época a proporcionalidade - $20 \%$ para os poderes públicos e $80 \%$ para a sociedade civil, entendendo o empresariado como parte da sociedade civil.

Segundo a tese de Cecília Souza,

a CPC do Rio também se posicionou em relação ao quórum qualificado para a aprovação de temas ditos - sensíveis. "Por fim, aceitar o quórum qualificado de $60 \%$ para aprovação de qualquer proposta, ou mesmo das propostas mais polêmicas, é 'engessar' previamente a I Confecom, antes mesmo que o debate seja travado", dizia a nota (SOUSA, 2014, p. 145).

Já a Comissão Pró-Conferência do Rio Grande do Sul, ainda antes do anúncio da saída dos empresários, criticou a proposta afirmando que "tal divisão é plenamente desproporcional e fere de morte, também por isso, um dos princípios da administração pública: a razoabilidade". Ademais, concluiu a nota.

esta divisão denuncia outra agrura política: o desrespeito ao princípio constitucional da igualdade. Ao dispor os delegados nesta proporção, usa-se o critério do poder econômico ao reverso. Isto é, quem deveria ter peso qualificado - visando equilibrar a relação desigual entre empresários e sociedade em geral - é igualado ao mesmo patamar do outro,",74

Para Pieranti (2013), as divergências, seja com relação ao quórum ou à proporcionalidade, são naturais num processo como este.

Das manifestações que presenciei nas etapas estaduais da conferência, principalmente em relação à polêmica proporcionalidade de participação 40-40-20, o que eu mais vi foram divergências, mas divergências respeitosas. E é isso, a conferência tem que ter divergências, não é um palco de pensamento uniforme, de pensamento único, o importante é que é a posição da maioria seja aprovada, acentuou. E isso foi se conseguindo, se construindo ao longo do tempo. Aos poucos a sociedade civil nos estados foi percebendo a necessidade de conferência, não de mera implosão da conferência, custe o que custar. (PIERANTI apud SOUSA, 2013, p. 160)

\subsubsection{A nota dos empresários que saíram da Confecom}

Aceitar a divergência, como parte do processo do diálogo, não foi exatamente o que aconteceu durante o processo de construção da Confecom, especialmente do lado dos empresários do setor privado de mídia. Depois de uma tensa reunião, no dia 13 de agosto de

\footnotetext{
${ }^{74}$ Nota da Comissão RS Pró-Confecom. Disponível em: <http://rsproconferencia.blogspot.com.br/2009/08/notada-comissao-rs.html>
} 
2009, entre os empresários e os ministros responsáveis pela coordenação da conferência, Hélio Costa (Comunicações), Franklin Martins (Secretaria de Comunicação Social) e Luiz Dulci (Secretaria-Geral da Presidência), foi feito o anúncio da saída de seis entidades empresariais da Comissão Organizadora. O ministro Hélio Costa, que, de fato, se empenhou para que os empresários permanecessem na $\mathrm{CON}$, tentou minimizar a decisão. Em entrevista publicada pelo Observatório do Direito à Comunicação, ele afirmou que eles só não participariam da comissão organizadora, o que não significava um abandono da Confecom. Existe apenas o afastamento do setor de radiodifusão liderado pela Abert (que representava a emissora da radiodifusão)

Pouco mais tarde, após a reunião, o grupo de empresários divulgou uma nota à imprensa comunicando o seu desligamento da Comissão. $\mathrm{Na}$ nota, as seis entidades empresariais que deixaram a Comissão (Abert (emissoras de rádio e televisão), ANJ (jornais), Abranet (provedores de internet), ABTA(TV por assinatura), Adjori Brasil (imprensa do interior) e Aner (editora de revistas) tentaram explicar a tomada de posição. No texto o grupo diz:

agradece o convite, mas alega que a defesa dos preceitos constitucionais da livre iniciativa, da liberdade de expressão, do direito à informação e da legalidade foi entendida, por outros integrantes da comissão, como um 'obstáculo à confecção do regimento interno'. Frisa que saiu por não ter interesse em impedir a livre realização da Confecom. ${ }^{75}$

E para finalizar eles alegam que "não se opõem a realização da Confecom e não impedirão a participação individual de suas representadas no processo". Mesmo depois de o regimento ter sido modificado para atender suas demandas, as empresas continuaram com a posição de não participar. Essa decisão enfraqueceu o segmento, mas o fato de ter permanecido no encontro os representantes da Abra e da Telebrasil foi fundamental para que a Conferência acontecesse.

A única das condições apresentadas pelas empresas não atendidas pelo governo foi em relação a estabelecer premissas e limites ao temário da conferência. Em especial, as empresas de radiodifusão queriam que fosse afirmado de antemão a defesa do capital nacional no setor e as demais entidades queriam garantir que serviços para os quais já existe regulação não

75 Empresários oficializam saída da Confecom. Teles e Band continuam. Disponível em: <http://www.telesintese.com.br/empresarios-oficializam-saida-da-confecom-teles-e-band-continuam/>. 
fossem colocados em pauta. O governo fez um apelo para que as premissas fossem exclusivamente os princípios constitucionais para a comunicação. ${ }^{76}$

Para Lima (2009), depois de encerrada a Conferência, a desistência dos empresários revelou uma dificuldade com o debate democrático:

Apesar de interessar a todos os atores um marco regulatório atualizado para as Comunicações, os empresários privados parecem acreditar que as políticas públicas continuarão sendo indefinidamente estabelecidas com a exclusão da cidadania. Não só porque, de outra forma, seus interesses correriam riscos, mas também porque não estão acostumados a negociar com a sociedade civil, a levar em conta o interesse público que se manifesta de forma organizada e, sobretudo, democrática. ${ }^{77}$

\subsection{A realização das conferências estaduais}

O processo de convocação das conferências estaduais acabou sofrendo atrasos em função da saída dos empresários e em razão das indefinições do regimento. Pelas normas estabelecidas, este processo só poderia ser desencadeado após publicação do mesmo. Antes disso, porém, encontros informais já estavam acontecendo. Algumas comissões estaduais já estavam formadas desde 2008, mas a maioria se organizou mesmo a partir de 2009, depois que parte dos empresários já havia saído do processo.

as Comissões Estaduais Pró-Conferência (CPCs) constituíam-se como espaços de mobilização e organização dos movimentos populares e organizações sociais que buscavam envolver, em nível estadual, a sociedade em todas as etapas do processo de Conferência. Cerca de 400 entidades estiveram envolvidas com as 23 Comissões Estaduais instituídas. (SOUSA, 2013)

A pauta da democratização da Comunicação acabou se tornando uma questão central em meio às demandas de outras entidades da sociedade civil, como o movimento negro e LGBT, exatamente pela sua capilaridade e essencialidade. Sem acesso aos meios de comunicação e à informação livre e diversificada qualquer luta desencadeada pelos movimentos sociais, que pretende o apoio e a mobilização da sociedade, tende a perder força e espaço.

\footnotetext{
${ }^{76}$ Empresários anunciam saída da comissão organizadora. Disponível em: <http://www.direitoacomunicacao. org.br/noticias.php?id=5390>.

${ }^{77}$ A grande mídia e a segunda Confecom. Disponível em: <http://www.cartamaior.com.br/?/Coluna/A-grandemidia-e-a-segunda-Confecom/22179>.
} 
Sousa destaca em sua pesquisa que,

além da articulação com o poder público local para a realização das etapas estaduais da Conferência, as CPCs também desenvolveram atividades de formação nas capitais e no interior dos estados e debateram propostas conjuntas para todo o processo, além de terem estado em constante diálogo com a Comissão Nacional Pró-Conferência. (SOUSA, 2013)

No começo de outubro de 2009, o processo estava bem adiantado, das 26 unidades da Federação mais o Distrito Federal, apenas seis estados ainda não haviam convocado suas conferências estaduais, como era o caso de Amapá, Amazonas, Rondônia, Tocantins, Maranhão e Santa Catarina. Neste caso, como já estava previsto no regimento, a Comissão Organizadora Nacional (CON) tinha poderes para nomear entidades que poderiam se responsabilizar pela sua realização e gerir os recursos a serem repassados. A CON poderia, inclusive, nomear pessoas da Comissão Nacional para ir aos estados e ajudar a realizar o encontro estadual, como foi o caso do professor Fernando Paulino que colaborou na realização da etapa estadual do Amazonas e Paraná.

Para garantir a representatividade desses estados, a comissão organizadora tomou a frente na coordenação de uma etapa preliminar mínima, fazendo um chamamento público da sociedade e representações empresariais nesses locais. Outra opção foi a escolha de delegados indicados diretamente pelo governo para representar os estados que não fizeram préconferência para a plenária nacional.

Nessa altura do processo, a Comissão Organizadora estava tentando recuperar parte do orçamento previsto para a realização da Confecom ( $\mathrm{R}$ \$ 8,2 milhões) que havia sido suspenso. Havia promessas de pronta recomposição do orçamento para a Confecom, que havia sido cortado no meio do processo das convocações municipais e estaduais, a expectativa era que até meados de outubro toda a verba fosse liberada, uma vez que a compra de passagens, reservas de hotel e todas as demais despesas dependiam destes recursos.

O Ministério das Comunicações explicou, na ocasião, que o presidente Lula iria sancionar o projeto de lei 27/2009, que iria recompor $\mathrm{R} \$ 6,5$ milhões anteriormente contingenciados pelo governo na programação original do evento. Ou seja, só havia R \$1,7 milhão para a realização da conferência, o que - certamente - iria inviabilizar a sua realização. O impasse, porém, foi superado a tempo, era mais uma forma de desmobiliar o 
movimento pró-conferência. Nesse momento, meados de outubro, ainda se planejava a realização da Confecom para os dias 1 e 2 de dezembro, mas logo depois foi adiada para os dias em que de fato aconteceu, entre 14 de 17 de dezembro de 2009.

Em cada estado, cuja conferência já estava convocada, o clima era muito positivo, eram feitos os preparativos para a realização das etapas regionais da conferência com a eleição de delegados, escolha do local para realização dos eventos, forma de submissão e análise das propostas, agenda de debates, enfim começava a se delinear em forma e conteúdo como a Confecom iria se desenvolver regionalmente. No Rio de Janeiro, por exemplo, além do encontro estadual os participantes conseguiram realizar a conferência municipal (Comucom RJ) que se realizou nos dias 16 e 17 de outubro. Sendo que a conferência estadual (Conecom RJ) nos dias 30 de outubro e $1^{\circ}$ de novembro nas dependências da UERJ (Universidade Estadual do Rio de Janeiro).

Em São Paulo o processo estava bem complicado e lento. A Conferência estadual deveria ter sido convocada até o dia 15 de setembro de 2009, de acordo com a Portaria 667, o que não aconteceu. Os organizadores e representantes das entidades sociais comentaram que a Assembleia Legislativa de São Paulo e o governo do estado não seriam favoráveis à realização do encontro. O Sindicato dos Jornalistas enviou carta à Secretaria de Comunicação do Governo de São Paulo pedindo urgência na publicação do edital, mas a secretaria da não respondeu. A convocação deveria ter sido feita pelo então governador José Serra.

Segundo a nota do Sindicato,

São Paulo, maior centro de produção e divulgação midiática do País, sede de grandes grupos de comunicação, região de maior concentração populacional e, portanto, importante espaço de produção e consumo popular de cultura e comunicação, ficou isolado, frustrando as expectativas da sociedade civil de criar um campo de debate democrático e plural sobre a questão. ${ }^{78}$

A Conferência Nacional, em dezembro, deve ser precedida de etapas preparatórias e da eletiva estadual, que deverá ser realizada até 8/11. A convocação em São Paulo acabou sendo convocada pelo Poder Legislativo. ${ }^{79}$

\footnotetext{
${ }^{78}$ Nota enviada pelo Sindicato dos Jornalistas de São Paulo. Disponível em: $<$ http://www.jornalistasp.org.br/index.php?option=com_content\&task=view\&id=2344\&Itemid=>.

${ }^{79}$ A etapa estadual de S. Paulo foi realizada no dia 24/09/09 sendo presidida pelo deputado Edmir Chedid (DEM). Disponível em: <http://www.al.sp.gov.br/noticia/?id=266396>.
} 


\subsection{A Resolução n. 8}

Quando se imaginava que a polêmica com os empresários, aparentemente superada, seria o único entrave, para que o processo caminhasse sem maiores dificuldades, entrou em cena a Resolução $n^{\circ} 8$, que chegou a ser apelidada de "AI 8"80 em referência ao autoritário AI 5, baixado pelos militares durante a ditadura. Em 23 de outubro de 2009, quando estava em amplo processo de realização das conferências estaduais, o Diário Oficial da União publica a Resolução $\mathrm{n}^{\mathrm{o}}$ 8, que determinou outra grande polêmica no escopo da metodologia da Confecom. As propostas apresentadas nas conferências estaduais seriam enviadas para a etapa nacional, sem votação.

Tal decisão da CON gerou muita crítica da sociedade civil organizada, que se reuniu em Brasília nos dias 23 e 24 de outubro de 2009 na Plenária das Comissões Estaduais e Nacional Pró-Conferência. O principal argumento era o de que essas etapas perderiam peso político e importância sem a votação de propostas (SOUSA, 2013).

Os participantes recorreram à Comissão Organizadora Nacional para que a decisão de não votação de propostas nas etapas eletivas fosse revista, mas a CON, reunida em 28 de outubro de 2009, não atendeu à demanda, segundo informação publicada no site do Fórum Nacional pela Democratização da Comunicação (FNDC). ${ }^{81}$

Em compensação, os participantes das comissões estaduais não tiveram que limitar o número de propostas a apenas 10 por cada eixo temático, como estava previsto originalmente. Nessa mesma reunião, a CON acatou outras reivindicações das entidades sociais fora do âmbito da Comunicação como a inclusão, na ficha de inscrição, dos itens cor, etnia, identidade de gênero, orientação sexual, grau de escolaridade e religiosidade.

\subsection{A abertura da etapa nacional da Confecom}

O impasse e a polêmica que surgiram durante o processo de preparação da Conferência acabou ressurgindo no dia da abertura do encontro, na manhã do dia 14 dezembro de 2009. Quando ficou definido no Regimento Interno da Confecom, que os

\footnotetext{
${ }^{80}$ Comissões protestam contra mudanças no regimento interno da Confecom. Disponível em: <http://www.direitoacomunicacao.org.br/content.php?option=com_content\&task=view\&id=5667>

${ }^{81}$ Reunião define algumas regras para etapas estaduais. FNDC, 28/10/2009.

Disponível em: <http://fndc.org.br/clipping/reuniao-define-algumas-regras-para-etapas-estaduais-448238/>
} 
empresários e as entidades sociais teriam direito, ambos, a $40 \%$ de participação, cabendo $20 \%$ aos representantes do Governo, esperava-se que - apesar de alguma insatisfação dos representantes dos movimentos sociais - a questão estaria superada e a própria realização da Confecom não estaria em risco.

Mas não foi o que aconteceu. A etapa nacional foi aberta com a volta da polêmica em relação ao regimento. Os representantes da Band queriam que, mesmo nos grupos de trabalho, prevalecesse a proporção 40-40-20. Os representantes da sociedade civil não empresarial votaram inteiramente contra essa ideia pela manhã. E essa atitude desagradou os empresários que, a noite, na abertura oficial ameaçaram deixar a Conferência.

Desce o Amilcare Dallevo Junior, empresário da Rede TV! e membro da CON, o Ceneviva (Walter Ceneviva, advogado, representante do Grupo Bandeirantes e membro da CON) e o Saad (João Carlos Saad, empresário do Grupo Bandeirantes e membro da CON)e juntos - antes da abertura oficial pelo presidente Lula - começam a pressionar no sentido de mudar a norma e ameaçam deixar a realização da Confecom. O que provocou atraso na abertura oficial da Confecom. O impasse fez com que os movimentos sociais cedessem. (VALENTE apud SOUSA, 2013)

O Coletivo Intervozes que era contrário a esse entendimento, considerou, nas palavras de um dos seus representantes, Jonas Valente, uma derrota para as entidades. Essa decisão gerou "uma plenária bombástica da sociedade civil no primeiro dia de conferência, que reivindicava, segundo ele, aos berros, a revisão da decisão da CON" (2013), o que não aconteceu. Mas o que Valente entendeu como um revés, Pieranti (2013) entendeu como uma saída para que o acordo fosse possível e a conferência fosse viabilizada. Este desacordo, logo no início dos trabalhos, já demonstrou a falta de coesão dentro do movimento. "Chegou-se ali ao acordo possível entre os diferentes atores naquele momento, e a conferência foi viabilizada. E essa interação entre sociedade, empresários e governo foi fundamental (PIERANTI apud SOUSA, 2013).”

De acordo com matéria publicada pelo jornal O Estado de S. Paulo ${ }^{82}$, o presidente Luiz Inácio Lula da Silva ameaçou boicotar a abertura da $1^{\text {a }}$ Conferência Nacional de Comunicação (Confecom), na segunda-feira, quando soube que havia risco de entidades empresariais saírem do evento. Lula só deixou o prédio do Centro Cultural Banco do Brasil (CCBB), onde estava despachando temporariamente, e foi ao Centro de Convenções Ulysses Guimarães, após obter garantia de que Walter Ceneviva, representante da Associação

\footnotetext{
${ }^{82}$ Lula chegou a ameaçar boicotar a abertura da Confecom. O Estado de S. Paulo, 15/12/2009, p. 4.
} 
Brasileira de Radiodifusores (Abra), formada pela TV Bandeirantes e Rede TV, não abandonaria a conferência. Na mesma matéria, o presidente afirma que "a Confecom só tem legitimidade com a participação do setor empresarial" e menciona o acordo feito entre empresários, organizações não-governamentais (ONGs), sindicatos e o Governo sobre os chamados "pontos sensíveis". Só se houver consenso uma tese vai para a frente, teria dito o então presidente Lula.

Em matéria publicada pelo jornal Folha de S. Paulo ${ }^{83}$, a edição destacou trechos do discurso de abertura de Lula onde ele ressalta que a imprensa no Brasil é livre e assim deve permanecer. "Tenho orgulho em dizer que a imprensa no Brasil é livre. Ela apura e deixa de apurar o que quer. Publica e deixa de publicar o que desejar. Opina e deixa de opinar sobre o que bem entende". O presidente Lula destacou, ainda, em sua fala que "tem compromisso sagrado com a liberdade de imprensa", mas aproveitou a oportunidade para chamar a atenção dos "excessos cometidos pela mídia". Essa mesma imprensa que tem liberdade para publicar o que quiser, destacou, "também se excede, despreza os fatos e embarca em campanhas, divulga inverdades ou mesmo dissemina calúnias e infâmias".

E em seguida criticou os empresários que desistiram de participar da Conferência, "não será enfiando a cabeça na areia como avestruz que resolveremos o problema (do marco regulatório da comunicação de massa no País). Isso vale para todos nós, governo, empresa, trabalhadores, movimentos sociais, ouvintes, leitores e telespectadores." De fato, "é chegada a hora de uma decisão que resgate os acertos e corrija o passado". ${ }^{84}$

\subsection{Como aconteceu a etapa nacional da Confecom}

A Conferência, enfim, aconteceu apesar de uma certa resistência de parte dos empresários do setor e de radicalismos superados das entidades sociais. A Confecom mobilizou 1.684 delegados que examinaram e discutiram mais de cinco mil propostas e aprovaram 633 sugestões, foram quatros dias de intensos debates, e acordos negociados entre os empresários, os movimentos sociais e o Governo.

A Conferência foi quase uma mini constituinte para tratar do Capítulo das Comunicações. Apesar de ter custado aproximadamente $\mathrm{R} \$ 8$ milhões aos cofres públicos, e de o Governo ter contratado os serviços da Fundação Getúlio Vargas (FGV), conceituada no

\footnotetext{
${ }^{83}$ Lula diz que defende imprensa livre, mas condena "excessos". Folha de S. Paulo, 15/12/2009, p. A9.

${ }^{84}$ Confecom e o controle social da mídia (ie: censura). O Estado de S. Paulo, 16/12/2009, p. 4.
} 
mercado, para auditar e compilar os resultados do encontro, o trabalho da Fundação deixou muito a desejar, o que frustrou bastante os representantes das entidades sociais.

Todavia, apesar dos percalços, consta no Caderno da $1^{\text {a }}$ Confecom, publicação do Ministério das Comunicações produzida pela FGV Projetos, unidade da Fundação Getúlio Vargas, que Brasília havia sediado o "maior encontro já realizado no País para discutir o futuro das Comunicações brasileiras, desde a Assembleia Nacional Constituinte de 1988". ${ }^{85}$

O evento, porém, foi pouco noticiado pelos meios de comunicação tradicionais, pois uma espécie de pacto de silêncio foi feito durante a cobertura do encontro. Foi o que denunciou o então vice-presidente da Federação Nacional dos Jornalistas (Fenaj), Celso Schroder, em matéria publicada no site do FNDC e replicado no site do Observatório da Imprensa: ${ }^{86}$ "a imprensa se comporta como sempre se comportou, com um manto de invisibilidade, um pacto de silêncio. A comunicação é o tema menos discutido no Brasil. Isso é um paradoxo," criticou o jornalista que também foi membro da Comissão Organizadora da Conferência.

Apesar da intencional "cegueira" por parte da mídia, não se trata - neste momento de discutir suas razões, mas de tentar compreender como foi que a Conferência transcorreu e como conseguiu inserir no cenário nacional novos e importantes atores, que passaram a representar não apenas os movimentos sociais que, historicamente, lutam pela democratização dos meios, mas importantes setores da sociedade civil que viram-se representados e dotados de direitos para participar de um debate que era permanentemente dificultado pelos empresários da mídia.

Embora a chegada ao Palácio do Planalto de um partido ligado aos movimentos sociais, como o Partido dos Trabalhadores em 2003, tenha contribuído para a realização de uma conferência voltada ao setor, isso não foi suficiente. Certamente, em face do compromisso do PT com a realização de conferências nacionais, como a da Saúde, no passado, que foi fundamental para a criação do Sistema Único de Saúde (SUS) ${ }^{87}$, estava sendo criado um ambiente positivo para que as discussões em torno da construção de um novo

\footnotetext{
${ }^{85} \mathrm{O}$ caderno da $1{ }^{\text {a }}$ Confecom foi editado pela Secretaria de Comunicação Social da Presidência da República foi publicado em 10 de junho de 2010. Disponível em: <http://pfdc.pgr.mpf.mp.br/atuacao-e- conteudos-deapoio/publicacoes/comunicacao/caderno-propostas-1a-confecom/view>.

${ }^{86}$ Fenaj acusa imprensa de manter 'pacto de silêncio' sobre a Confecom. Disponível em: <http://www.observatoriodaimprensa.com.br/news/view/comuniquese_38781>.

${ }^{87}$ A 8 a Conferência Nacional de Saúde resultou na implantação do Sistema Unificado e Descentralizado de Saúde (SUDS), um convênio entre o Inamps e os governos estaduais, que mais tarde se tornou apenas Sistema Único de Saúde (SUS).
} 
marco regulatório para a comunicação no Brasil começassem a ganhar peso e passassem a fazer parte da agenda do Congresso Nacional.

De fato, naquela ocasião, ocorreu uma conjugação de fatores favoráveis à discussão da democratização dos meios no Brasil. Além da revolução tecnológica, que afeta todo o mundo contemporâneo - exigindo decisões legais e tecnológicas por parte do Poder Público - o Governo não poderia mais ignorar o assunto e os apelos dos movimentos sociais que defendiam um novo marco regulatório para o setor.

Amplos setores dos movimentos dos trabalhadores e demais movimentos sociais como o movimento em defesa da causa negra, em defesa das mulheres e de demais correntes que defendiam os direitos das minorias apoiaram e trabalharam no sentido de fortalecer o movimento pró-conferência.

De acordo com artigo do professor Dantas (2010), da UFRJ, que também participou ativamente da Confecom, "para votar as teses, obedeceram-se as regras determinadas por força de um jogo político pesado (...).O empresariado exigiu que as plenárias e GTs fossem proporcionalmente divididas em $40 \%$ de delegados empresariais, $40 \%$ de delegados não empresariais (ou seja, das entidades civis) e 20\% de delegados do Governo", apesar de estarem numericamente sub-representados e serem parcela ínfima da sociedade brasileira como um todo.

\subsubsection{As discussões e votações nos Grupos de Trabalho}

Os três eixos temáticos da Confecom abrigaram um total de 15 Grupos de Trabalho (GTs) com os seguintes assuntos: "produção de conteúdo", "meios de distribuição" e “cidadania, direitos e deveres". Alguns temas, pelo caráter multidisciplinar, acabavam se repetindo em mais de um grupo, o que acabou gerando confusão e até contradições no resultado.

O GT4, por exemplo, tratava de conteúdo nacional, propriedade das entidades produtoras de conteúdo, propriedade intelectual, aspectos federativos, um leque amplo de assunto que poderia sugerir um campo fértil para polêmicas, mas foi o que conseguiu apresentar "a maior taxa de convergência entre todos os grupos: 75,8\%, considerando as propostas aprovadas por consenso (35 do total de 66). Já o grupo que apresentou a menor taxa de aprovação foi o GT7. Esse grupo tratou dos "meios de distribuição: televisão aberta, TV por assinatura, cinema, multi programação, mídia impressa, mercado editorial, 
responsabilidade editorial e publicidade". Nesse grupo, assim como no GT6, o conflito entre os empresários e os movimentos sociais foi muito acirrado.

Segundo Dantas (2010), "no GT7 o principal confronto se deu entre a Abra e o Coletivo Intervozes, interpretando este um sentimento generalizado dos movimentos sociais quanto à gestão do espectro na TV digital". Enquanto a Abra queria liberdade para multiplexar seus canais abertos de $6 \mathrm{MHz}$, fazendo, na prática, de um canal mais quatro ou cinco, o Intervozes defendia que a multiprogramação somente poderia ser permitida quando vinculada ao programa no ar. Os dois lados levantaram mútuas "questões sensíveis" e as duas teses caíram.

No GT6, que tratou da internet, banda larga e infraestrutura, o confronto foi parecido. "Aqui se testemunhou muito claro e acirradamente um conflito entre os empresários, especialmente os da Telebrasil, e os trabalhadores liderados pela CUT" (DANTAS, 2010). Era sabido que o Governo estava dando os contornos finais para um plano nacional de banda larga, para disseminar essa infraestrutura no País, e que ela previa a reativação da Telebrasil. A CUT queria que a Telebrás fosse reativada e fortalecida com recursos do Fundo de Universalização dos Serviços de Telecomunicações (FUST), e que coordenasse a criação da infraestrutura pública a partir das redes estatais ociosas. A Telebrasil foi contra e vetou a ideia. Nesse mesmo grupo, o Intervozes propôs "separação estrutural de redes, determinando o desmembramento das empresas de telecomunicações em empresas detentoras de redes e outras prestadoras de serviços". Mais uma vez, a Telebrasil alegou "questão sensível" e derrubou a proposta. A CUT, por sua vez, alegou o mesmo mecanismo para impedir que uma proposta dos empresários seguisse adiante.

Por essa proposta, além da desoneração tributária reivindicada para as empresas do ramo, a Telebrasil queria "a redefinição de competências de estados e municípios para disposições de natureza urbanística e ambiental" e, ainda, a "oferta de outorgas para a prestação de serviços". As entidades do movimento, lideradas pela CUT, impediram a aprovação. Aos poucos, os dois lados perceberam que seria necessário diálogo, acordo e consenso para que as votações avançassem, do contrário, um segmento iria boicotar outro.

Essa postura conciliatória, dos dois lados, apareceu muito claramente nas propostas do GT15 que, pelo conteúdo, intensificaria os debates. Esse grupo abarcou as questões de cidadania, com relação ao respeito e promoção da diversidade cultural, religiosa, étnico-racial, de gênero, de orientação sexual e de proteção a segmentos vulneráveis como crianças e adolescentes. No entanto, das 135 teses apresentadas, 122 foram aprovadas por consenso. Esse aparente consenso sugere, porém, que as propostas eram tão genéricas e de difícil ataque 
que, certamente, era mais fácil para os empresários aprovarem do que baterem de frente em assuntos que são muito caros a toda a sociedade. Quem seria louco de não apoiar punições a comportamentos racistas? Todavia, a tese que previa fixação de $50 \%$ de cotas para negros nos meios de comunicação não prosperou. O consenso se deu pelo caráter genérico das proposições.

\subsubsection{Os acordos e a "questão sensível"}

De acordo com as regras estabelecidas entre as partes, ficou acertado que qualquer questão era considerada "sensível" quando um dos três segmentos (organizações sociais, empresas ou Governo) exigisse esse status com o apoio de metade dos seus membros. $A$ posteriori a aprovação de uma proposta com esse carimbo só seria possível se conseguisse 60\% mais um dos votos da Plenária, com pelo menos um voto em cada segmento. Ou seja, um critério que, praticamente, impediria a aprovação de qualquer proposição cunhada de "sensível”, como desejava os empresários.

Essa salvaguarda foi criada para atender, especialmente, os representantes do setor privado empresarial, mas acabou também sendo utilizada pelos representantes das organizações sociais quando estas se viram pressionadas a aprovar um tema com o qual não concordavam. A CUT, em algumas votações, alegou tal mecanismo. ${ }^{88}$

De acordo com o Caderno da Confecom, produzido pela Fundação Getúlio Vargas (FGV), foi verificado que, do total de 119 propostas encaminhadas para a Plenária, 13 foram derrubadas pelo mecanismo da "questão sensível", ou seja, não foram nem aprovadas nem rejeitadas. Os dois lados boicotavam as propostas com as quais discordavam. Vale lembrar que a Conferência analisou um total de 1.422 teses, sendo que quase $50 \%$ foram aprovadas pelos Grupos de Trabalho e só as que não alcançaram $80 \%$ de consenso é que foram enviadas para a Plenária final.

É importante explicar porque a chamada "questão sensível" - que chamou a atenção dos jornais e dos sites, e gerou dúvidas com relação às decisões desta pesquisadora - acabou não se consubstanciando em uma categoria de análise. Inicialmente, pensou-se em criar categorias ancoradas em questões eleitas como as mais polêmicas. Porém, após uma análise, chegou-se à conclusão que elas tinham quase que a mesma raiz. Com exceção de três

\footnotetext{
${ }^{88} \mathrm{~A}$ PL n ${ }^{\text {o }} 430$ foi vetada pela CUT com a alegação do mecanismo de "questão sensível”, por entender que o setor privado seria beneficiado com a desoneração tributária, caso aderisse ao plano nacional de banda larga. A CUT decidiu vetar essa proposição. Para retaliar, uma proposta do Intervozes, que tinha o apoio da CUT, foi vetada pela Telebrasil. Foi a PL n ${ }^{\circ} 427$, que propunha o fortalecimento da Telebrasil. Ou seja, os dois lados ficaram - em muitas votações - sabotando o processo, sem sequer avaliar o mérito das propostas.
} 
propostas que fugiram do quesito tecnológico, as outras dez dialogavam entre si e transitavam dentro do complexo tema da infraestrutura das telecomunicações. Por isso, foram tratadas na categoria que abarcou os temas ligados à Tecnologia.

Após a leitura do material e do balanço das propostas aprovadas e não aprovadas ao final da Confecom, pensou-se que seria pertinente eleger as propostas que suscitaram a arguição do chamado mecanismo da "questão sensível" como possíveis indicadoras de análise do todo. Mas essa percepção não foi a mais adequada, pois as propostas que foram derrubadas pela questão sensível não foram tão relevantes dentro do contexto.

Os 15 grupos de trabalho que foram criados pelo regimento da Conferência analisaram as 1.674 teses que foram recolhidas das conferências estaduais que, inicialmente, trouxeram mais de cinco mil proposições. Desse total, as que obtinham a aprovação de $80 \%$ dos delegados eram automaticamente aprovadas, e as que não obtinham nem $30 \%$ eram automaticamente excluídas. "Das que não tinham mais de $80 \%$ nem menos de $30 \%$ dos votos, cada segmento da sociedade, empresários e movimentos sociais escolheria quatro para enviar à Plenária, podendo o Governo escolher duas de seu interesse" (DANTAS, 2010, p. 2).

Mas nem todos os GTs encaminharam propostas para votação final. Logo, apenas 71 foram para a Plenária e destas apenas 13 foram derrubadas pelo mecanismo da "questão sensível" que, apesar de indicar absoluto desacordo entre as partes, não foi muito revelador do ponto de vista da exposição dos entraves que poderiam afastar os dois lados da querela, de um possível consenso. Das 13, algumas diziam respeito a questões de ordem tributária.

Outra questão que foi derrubada por este mesmo instrumento, foi a que propunha o estabelecimento de cotas de programação, que fazia parte do Grupo de Trabalho denominado “produção de conteúdo". Essa proposta, que "apenas” exigia que os canais de TV abertos e fechados obedecessem à Constituição, foi rechaçada pelos empresários. Ela propunha que fossem estabelecidas cotas de $10 \%$ para atendimento a finalidades educativas e culturais e $30 \%$ para a programação regional. Ou seja, até mesmo as TVs fechadas só poderiam dispor livremente de $60 \%$ de sua rede de programação.

A PL $n^{\circ} 440$, que foi analisado pelo GT4, dentro do mesmo eixo temático da questão anterior, também era sobre a fixação de cotas e com um viés bastante utópico. A proposta, que foi rejeitada, defendia a instituição de "cotas crescentes" nos canais de televisão abertos e fechados, para a "veiculação de animação produzida nacionalmente". Nesse ponto, a Associação Brasileira de Radiodifusão (Abra) foi contra os criadores nacionais de desenhos animados. O curioso é que é um segmento ainda incipiente no Brasil que, nem de longe, 
concorre com a longa história do cinema nacional, e lutou por cotas de exibição que nem o cinema consegue, de fato, consolidar.

A terceira "questão sensível”, que está fora do quesito tecnológico, é a de n 284 , pertencente ao GT3, ainda dentro do mesmo eixo temático da produção de conteúdo. Esta PL pedia a criação de um "conselho gestor/agência nacional de regulação da mídia sobre qualidade da programação midiática, concessões de canais e redes de TV e rádio ${ }^{89}$ ". O empresariado presente no GT3 acionou o mecanismo da "questão sensível" para vetar essa proposta, que era de interesse dos movimentos sociais. Como os representantes da sociedade civil haviam agido da mesma forma, pouco antes, para evitar que a desoneração fiscal fosse obtida pelos empresários, eles agiram para retaliar o segmento.

Os empresários queriam mudar a forma de enquadramento estabelecida pela Receita Federal para a cobrança de impostos, pois esta leva em conta a natureza do serviço para fazer tal enquadramento e não a capacidade econômica da empresa. Caso essa proposta fosse aceita, as empresas de telecomunicação poderiam fazer parte do Simples, que é um sistema que prevê tributação mais baixa, inclusive com redução indireta sobre os encargos sociais, uma vez que o custo da Previdência Social é bem mais baixo. Praticamente todas as teses que pretendiam mexer na questão tributária foram recusadas pelos representantes da sociedade civil.

Para um dos participantes da Conferência que atuou ativamente no GT7 (que tratou da televisão aberta, fechada e da multiprogramação, entre outros assuntos), o professor da Escola de Comunicação da Universidade Federal do Rio de Janeiro (UFRJ), Marcos Dantas, os representantes do GT3 optaram pela recusa da desoneração tributária por absoluta falta de conhecimento do assunto.

O mais curioso desse GT3, que recusou a criação do "conselho gestor/agência nacional", fazendo valer o mecanismo da "questão sensível", é que proposta similar já havia sido aprovada pelo GT1, grupo que tratou - dentro do item "produção de conteúdo" - das questões afetas à produção independente e regional, e da garantia de distribuição, mas que também tratou dos conselhos. Por meio da PL n ${ }^{\circ} 712$, aprovada pela Plenária, a Conferência aprovou "a criação de conselhos federal, estaduais e municipais de Comunicação, constituídos por representantes dos governos e da sociedade civil." Uma das atribuições desses conselhos seria exatamente a "regulação de conteúdo".

Para explicar a última "questão sensível", é preciso destacar a PL n 34. Essa proposta, de fato, conseguiu unificar o posicionamento contrário de todos os empresários do

\footnotetext{
${ }^{89}$ Todas as PLs citadas aqui foram extraídas do documento final sistematizado pela Fundação Getúlio Vargas.
} 
setor. Os movimentos sociais queriam garantir, junto às emissoras de rádio e TVs abertas, o mesmo benefício que gozam os partidos políticos. Eles queriam ter o direito de veicular inserções das organizações da sociedade civil, de forma gratuita e garantida, em todos os canais de TV e emissoras de rádio. Mais uma vez, ficou notória a contradição por conta da desorganização eventual na condução das votações ou pelo excesso de assuntos controversos, pois tese similar foi aprovada pelo GT8 - a PL n ${ }^{\circ}$ 79. Esse GT8, pertencente ao eixo temático "meios de distribuição", tratou do sistema de outorgas, fiscalização e propriedade das entidades distribuidoras de conteúdos.

A proposta $n^{\circ} 79$ tratou dos quesitos exigidos para a concessão de canais de TV. Em meio a outros detalhes, oferecia tempo gratuito, na programação das emissoras, para as organizações sociais. Essa proposta estava junto com outras duas que tratavam das novas regras que seriam definidas no conjunto das novas normas legais que seriam criadas. Essas teses queriam atingir as TVs abertas que sublocam seus horários para programas religiosos e para os chamados programas de "televendas".

Do ponto de vista mais geral das proposições, apesar de a Conferência ter aprovado a criação dos conselhos federal, estaduais e municipais de comunicação - uma das teses mais importantes aprovadas - os empresários aparentemente ficaram satisfeitos com o resultado da Conferência. Ficou claro que os que permaneceram na Confecom, como o Grupo Bandeirantes, marcaram posição contra a hegemonia do Sistema Globo de Comunicação, representado pela Abert, e trataram de defender seus interesses mais específicos. Certamente, se todas as seis entidades que abandonaram o encontro tivessem permanecido, os debates teriam sido mais duros e dificilmente o grau de consenso obtido teria sido o mesmo.

Segundo interpretação de Dantas,

sem os demais empresários ficou claro que, para a Telebrasil, interessava essencialmente remover as amarras legais que impedem as concessionárias de telecomunicações de investir na TV por assinatura, manter o modelo consagrado na Lei Geral das Telecomunicações (LGT), e apoiar a universalização da banda larga". (DANTAS, 2010).

A rede Bandeirantes não parecia estar muito preocupada com as teses que trataram do combate aos monopólios nem tampouco com a tese do "controle social da mídia", mas em aprovar a "multiplexação do canal digital", que foi derrotada. Uma boa parte das teses defendidas pelos movimentos em defesa da democratização da mídia foi atendida. 


\subsubsection{Síntese das propostas aprovadas pela Confecom}

A seguir, uma síntese das principais propostas aprovadas pela Conferência:

$\checkmark$ Criação do Conselho Federal de Jornalismo;

$\checkmark$ Criação do Código de Ética do Jornalismo;

$\checkmark$ Aprovação da volta da obrigatoriedade do diploma para jornalista;

$\checkmark$ Criação do Observatório Nacional de Mídia e Direitos Humanos;

$\checkmark$ Criação de uma nova Lei de Imprensa;

$\checkmark$ Criação de cotas para programas educacionais, culturais e informativos em TVs abertas e por assinatura;

$\checkmark$ Criação de cotas para canais e programas, e programas nacionais em TV por assinatura. Pelo menos $50 \%$ dos canais de qualquer pacote teriam de ser nacionais;

$\checkmark$ Restrições à propriedade de veículos de comunicação por uma mesma pessoa, a chamada propriedade cruzada;

$\checkmark$ Limitar a formação de redes nacionais por emissoras de TV;

$\checkmark$ Redução do limite do capital externo, de 30\%, para $10 \%$ em empresas de comunicação;

$\checkmark$ Fiscalização com controle social das obrigações trabalhistas das empresas de Comunicação;

$\checkmark$ Criação de uma empresa pública para incentivar a distribuição de filmes e vídeos;

$\checkmark$ Proibir a venda ou o aluguel de espaços na grade da programação das emissoras;

$\checkmark$ Criar mecanismos de fiscalização para punir rádios e TVs que veiculem conteúdos depreciativos contra minorias;

$\checkmark$ Universalizar o acesso à banda larga;

$\checkmark$ Distribuição equânime das concessões de canais de TV por assinatura entre a iniciativa privada, a sociedade civil e o Poder Público. 


\section{CAPÍTULO 3}

\section{OBJETO, PROBLEMA DE PESQUISA E JUSTIFICATIVA}

A presente pesquisa definiu o seu objeto a partir da cobertura dada à Conferência, por parte dos dois segmentos que mais se confrontaram durante o evento, os representantes tradicionais da mídia impressa e os representantes dos movimentos sociais. O objeto foi construído a partir dos discursos dos empresários do setor privado de mídia e dos representantes das entidades sociais que defendem a democratização da mídia divulgados por meio dos jornais $O$ Estado de S. Paulo, a Folha de S. Paulo e $O$ Globo e sites do Fórum Nacional pela Democratização da Comunicação (FNDC) e do Coletivo Intervozes que cobriram a primeira e única Conferência Nacional de Comunicação (Confecom) ocorrida em Brasília entre os dias 14 e 17 de dezembro de 2009.

Estes discursos ressignificaram o confronto histórico de ideias e concepções entre os atores envolvidos na contenda da regulação da mídia, que teve início - na sua fase contemporânea - nos começo da década de 1960, quando o Código Brasileiro de Telecomunicações foi aprovado, recrudesceu nos debates da Assembleia Nacional Constituinte de 1987\88, e ao longo dos últimos 25 foi permeado de acordos e desacordos nos momentos marcantes em que parte do arcabouço legal do setor foi sendo modificado.

Este discurso de confronto - que a cada episódio de embate foi evoluindo - ganhou força e tomou forma durante os quatro dias da Conferência - tantos nos jornais como nos sites pesquisados - e acabou por expor com clareza o discurso contra hegemônico das entidades sociais em face do discurso hegemônico do setor privado. E foi sobre esse confronto discursivo que a pesquisa se debruçou para entender porque a Confecom acabou por remexer em velhos tabus e crenças que impedem que a discussão sobre o marco regulatório avance. E entender ainda porque o consenso entre estes atores é tão difícil de ser alcançado.

A ideologia de cada um dos lados, que veio a tona durante os debates, mediados pela cobertura do evento, mostrou que ainda é forte a convicção de certos valores defendidos pelo setor privado desde a Constituinte e que - do mesmo modo - também é enorme a resistência das entidades sociais no sentido de abrir mãos de certos dogmas e crenças que foram se consolidando ao longo dos últimos 50 anos de enfrentamento.

A Confecom ofereceu a possibilidade para que um consenso entre as partes envolvidas pudesse ser alinhavado, mas a postura adotada por cada um dos lados impediu este avanço e mostrou que do ponto de vista discursivo, os empresários - buscaram reposicionar seu 
discurso histórico contra a democratização da mídia - e os movimentos sociais aproveitaram o evento para reafirmar as suas posições e dar visibilidade à luta a favor dessa democratização. É este, portanto, o argumento central desta tese. O estudo não foi em busca do que a Confecom aprovou ou deixou de aprovar, e sim em busca do que cada um dos atores disse e deixou de dizer sobre os elementos centrais da disputa, como o controle social da mídia, a liberdade de expressão e de imprensa, a concentração dos meios e a propriedade cruzada.

A argumentação discursiva - criada por cada uma das partes envolvidas - se constituiu num rico conjunto de elementos que possibilitou a construção de categorias de análise que ajudaram a desvelar o que cada discurso pretendia encobrir. Este trabalho, portanto, analisa o confronto entre os discursos hegemônico e contra hegemônico construídos por ocasião da Confecom, pelos donos da mídia tradicional, representados pelos jornais $O$ Estado de $S$. Paulo, Folha de S. Paulo e $O$ Globo, e pelas entidades civis que defendem a democratização da comunicação, representadas pelo Fórum Nacional pela Democratização da Comunicação (FNDC) e o Coletivo Intervozes.

Durante a Assembleia Nacional Constituinte (1987/88) foi a ocasião em que os empresários de mídia e os representantes das entidades sociais, de fato, se reuniram, pela primeira vez de modo mais amplo para discutir as bases do sistema de comunicação do País, foi uma pauta extensa e aberta. Nesses 21 anos que separam a Constituinte da Confecom prevaleceu um certo distanciamento, embora o diálogo entre ambos tenha sido retomado em alguns momentos específicos, como a criação da Lei do Cabo, de 1995, a criação da EBC (Empresa Brasileira de Comunicação) em 2007 e outras questões pontuais, que estão explicitadas na Contextualização.

A não regulação dos artigos do Capítulo V da Constituição acabou por impulsionar o crescimento do setor privado de mídia com o aumento da concentração dos meios de comunicação e o descontrole sobre a propriedade cruzada.

Dos anos de 1990 até o início do ano 2000, o que se configurou de maneira acentuada foi o movimento ascendente de concentração da mídia nacional e a consequente redução drástica de grupos (em sua maioria, empresas familiares) no controle dos principais veículos de comunicação do país. Algo em torno de nove grupos familiares controlavam a grande mídia no decorrer da última década (1990): Abravanel (SBT), Bloch (Manchete), Civita (Editora Abril), Frias (Folha de S. Paulo), Levy (Gazeta Mercantil), Marinho (Organizações Globo), Mesquita ( $O$ Estado de $S$. Paulo), Nascimento Brito (Jornal do Brasil) e Saad (Rede Bandeirantes)". ${ }^{0}$

\footnotetext{
${ }^{90}$ Os donos da Mídia. Disponível em: <http://go.microsoft.com/fwlink/?LinkId=72186>
} 
Mas hoje este quadro se alterou com a extinção da Manchete, da Gazeta Mercantil e do Jornal do Brasil. Ainda assim a concentração permanece nas mãos de poucos grupos.

Um estudo feito em 2002 pelo Instituto de Estudos e Pesquisas em Comunicação (Epcom), intitulado Os donos da Mídia, sobre os meios de comunicação no Brasil mostra que a essas três redes nacionais, além de Record, Rede TV! e CNT, estão aglutinados 668 veículos em todo o país. São 309 canais de televisão, 308 canais de rádio e 50 jornais diários. Os chamados "donos da mídia" no Brasil, então, são as famílias que controlam as redes privadas nacionais de TV aberta e seus 138 grupos regionais afiliados, que são os principais grupos de mídia nacionais ${ }^{91}$

Como se vê, em face destes dados, quando esta pesquisa se refere à "grande imprensa" ou "aos donos da mídia", não é apenas uma força de expressão. Em pesquisa realizada em 2005, pelo Fórum Nacional pela Democratização da Comunicação (FNDC), ela revela o grau de concentração no setor de radiodifusão. O sistema brasileiro de televisão é composto, atualmente, de 332 emissoras, sendo que 263 estão vinculadas às redes Globo, SBT, Record, Bandeirantes, Rede TV! e CNT. Segundo a pesquisa, Globo e SBT possuem, respectivamente, 20 e 11 emissoras próprias, o que não é permitido pelo decreto-lei n ${ }^{\circ}$ 236/67 em seu artigo12, o qual determina que uma mesma entidade só pode deter um máximo de 10 concessões de radiodifusão de sons e imagens (TV aberta) em todo o território nacional". ${ }^{22}$

O cenário concentrado no segmento privado de mídia explica a dificuldade dos empresários em discutir e rever suas posições com relação a um modelo de regulação democrático e inclusivo. Durante a Confecom, por meio das matérias e artigos analisados, esse discurso dos "donos da mídia" foi problematizado e analisado diante dos embates que surgiram nas mesas de negociação com os representantes das entidades sociais com a mediação dos representantes do Governo. O argumento central desta tese é que, do ponto de vista discursivo, os empresários buscaram reposicionar seu discurso histórico contra a democratização da mídia enquanto os movimentos sociais, por sua vez, aproveitaram o evento para dar visibilidade à luta pela democratização e conquistar apoio popular graças à visibilidade possibilitada pela Internet. O diálogo entre estes dois segmentos, apesar das conversações, pouco avançou em termos mais concretos.

\footnotetext{
${ }^{91}$ Os donos da Mídia. Disponível em: 〈http://go.microsoft.com/fwlink/?LinkId=72186>

${ }^{92}$ Os donos da Mídia. Disponível em:

<http://www.direitoacomunicacao.org.br/index2.php?option=com_docman\&task=doc_view\&gid=342\&Itemid= 99999999>.
} 
Todavia, a Conferência criou uma oportunidade de remexer em temas - aparentemente já resolvidos - como a liberdade de imprensa, a regulação dos meios de comunicação e a preparação do setor, e até mesmo, da sociedade para lidar com a revolução tecnológica que alterou de forma definitiva o mundo da comunicação pós-web.

Outra percepção que surgiu do cenário de embates observado durante a Confecom, e que será problematizado nesta discussão, foi o fortalecimento de um novo ator, que não existia em 1988: os representantes do gigantesco setor das telecomunicações, que assumiram uma nova posição diante do advento da internet e tornaram-se bem distintos daqueles que existiam há duas décadas. Durante a Conferência, em muitos momentos, eles se afastaram dos empresários da radiodifusão e expuseram a cisão do conglomerado midiático. Como consequência, os empresários do setor privado participaram das negociações divididos e fragmentados, e isso fortaleceu ainda mais as empresas de telecomunicação.

Os principais representantes das empresas de radiodifusão, além de terem saído da organização da Conferência, optaram por abandonar o evento ${ }^{93}$ (como será detalhado no Capítulo que trata especificamente da Confecom) e essa ausência abriu espaço para os representantes das empresas de telecomunicação. Ainda no mês de agosto de 2009, durante as reuniões da Comissão Organizadora Nacional (CON), a Associação Brasileira das Emissoras de Rádio e Televisão (Abert) optou por sair do processo de organização da Conferência, juntamente com a TV Globo, e mais seis entidades, A saída desses empresários teria acontecido em função de desentendimentos durante as discussões sobre o sistema de votação que seria adotado durante a Conferência.

As empresas queriam que o voto delas tivesse o mesmo peso que o das entidades representativas dos movimentos sociais, e que o Poder Público tivesse o menor. Depois de muitas discussões ficou acertado que as empresas ficariam com $40 \%$, as entidades com outros $40 \%$ e o Governo com 20\%. Embora em número menor, as empresas ficaram com o mesmo peso que as entidades, na hora das votações. Mas apesar de todo o esforço do então ministro das Comunicações, Hélio Costa, que, muitas vezes, se posicionou favoravelmente aos interesses dos empresários, seis entidades ligadas à Abert decidiram, no dia 13 de agosto de 2009, depois de tensa reunião no Palácio do Planalto, abandonar as reuniões preparatórias e não participar do encontro nacional.

\footnotetext{
${ }^{93}$ Em nota divulgada à imprensa no dia 13 de agosto de 2009, as seguintes entidades anunciaram seu desligamento da Comissão Organizadora: a Aner (editora de revistas), a ANJ (jornais), a Adjori (imprensa do interior), a Abert (emissoras de rádio e televisão), a Abranet (provedores da internet) e a ABTA (TV por assinatura). Disponível em: 〈http://www.telesintese.com.br/confecom-a-integra-da-nota-dos-empresarios >
} 
Em face destas questões expostas, a presente tese extraiu do discurso manifesto - tanto pelos empresários como pelos representantes dos movimentos sociais - que muitas das questões que são fundamentais para que se tenha uma comunicação democrática de fato discutidas no âmbito da Constituinte foram revisitadas no palco da Conferência Nacional de Comunicação e ainda não estão adequadamente pacificadas. Passados mais de vinte anos da promulgação da nova Carta Constitucional, a Confecom reascendeu velhos dogmas e desmascarou velhos temores como o medo da volta da censura prévia, o estabelecimento de mecanismos de acompanhamento e fiscalização da mídia e o receio de que os oligopólios e a concentração da mídia estejam sob ameaça.

O objeto de análise desta pesquisa - os discursos manifestos do empresariado e do movimento social pela democratização da mídia - tem, naturalmente, as suas limitações. Na análise procurou-se posicionar estes dois segmentos historicamente (do ponto de vista do discurso) considerando que essa trajetória tem um lastro histórico construído na luta pelo direito humano à comunicação, não só do acesso livre à informação, como também à sua produção. Esta tese, portanto, discute a trilha do discurso destes dois lados, tradicionalmente adversários, que culminou na Conferência Nacional de Comunicação. A investigação não teve a pretensão de avaliar se a Confecom atingiu os seus objetivos pragmáticos, nem tampouco avaliar se o seu legado será aproveitado pelas políticas públicas de Governo, e nem pode identificar se o tema da regulação democrática dos meios ganhou popularidade junto à sociedade como um todo. O foco, portanto, foi no discurso. Ela pode ser assim resumida:

Quadro1- Objetivos da pesquisa.

\begin{tabular}{|c|l|l|}
\hline 1 & A pesquisa se propôs a & $\begin{array}{l}\text { analisar o discurso dos movimentos sociais em defesa da } \\
\text { democratização da comunicação, e o discurso de reação da } \\
\text { mídia tradicional: ambos construídos e expostos durante a } \\
\text { Confecom e manifestos pela cobertura de três grandes jornais } \\
\text { brasileiros e dois sites ligados aos movimentos. }\end{array}$ \\
\hline 2 & Para & $\begin{array}{l}\text { expor os argumentos apresentados no discurso da mídia } \\
\text { tradicional e no discurso dos movimentos sociais contra e a } \\
\text { favor da democratização da comunicação. }\end{array}$ \\
\hline 3 & Com a finalidade de & $\begin{array}{l}\text { verificar como estes dois segmentos da mídia aproveitaram a } \\
\text { oportunidade criada pela Confecom para reposicionar e expor as } \\
\text { suas posições diante dos avanços da tecnologia e da } \\
\text { necessidade de um novo marco regulatório para o setor }\end{array}$ \\
\hline 4 & Permitir & $\begin{array}{l}\text { avaliar como a sociedade civil e o setor privado de mídia se } \\
\text { colocam diante de desafios presentes desde a Constituinte de } \\
1988, \text { e que agora estão ressignificados pela nova realidade pós- } \\
\text { Internet. }\end{array}$ \\
\hline
\end{tabular}

Fonte: Elaborado pela autora 
Foram analisados artigos e matérias produzidos por dois sites que representam as entidades sociais que lutam pela defesa da democratização da comunicação no Brasil (o do Fórum Nacional em Defesa da Comunicação (FNDC) e o site do Coletivo Brasil de Comunicação Social, denominado Intervozes), e o conteúdos de três jornais de grande circulação (Estado de S. Paulo, Folha de S. Paulo e $O$ Globo). Estes jornais, embora não possam ser de fato considerados "nacionais" - pois não conseguem penetrar em todos os municípios brasileiros, são assim denominados por serem representantes da chamada mídia tradicional ou "grande imprensa", e por serem reconhecidos como "formadores de opinião". O recorte do tempo observado para o corpus foram os 10 dias que antecederam o evento e os 10 posteriores, além dos 4 dias da Conferência, que aconteceu entre os dias 14 e 17 de dezembro de 2009. Portanto, estamos falando aqui do material produzido e publicado entre os dias 4 e 27 de dezembro daquele ano.

\subsection{O corpus da pesquisa}

Este material contém editoriais, artigos, matérias, e notinhas, e a opção adotada para tratar de todos eles foi denominá-los como "produtos". Logo, a quantidade de produtos analisados chegou a 100, cuja síntese segue adiante, no Quadro 2:

Quadro2: Síntese quantitativa do corpus.

\begin{tabular}{|c|c|}
\hline Jornal & Quantidade de produto \\
\hline O Estado de S. Paulo & 14 \\
\hline Folha de S. Paulo & 15 \\
\hline O Globo & 10 \\
\hline Total & $\mathbf{3 9}$ \\
\hline & Quantidade de produto \\
\hline Site & 22 \\
\hline FNDC & 39 \\
\hline Intervozes & $\mathbf{6 1}$ \\
\hline Total & \\
\hline
\end{tabular}


Quadro 3: Síntese do conteúdo do jornal O Estado de S. Paulo.

\begin{tabular}{|l|l|}
\hline \multicolumn{1}{|c|}{ Data } & \multicolumn{1}{c|}{ Título } \\
\hline $13 / 12 / 2009$ & $\begin{array}{l}\text { (P1)Conferência de Comunicação quer recriar cabides de emprego. Matéria. Pág. } \\
\text { 05. }\end{array}$ \\
\hline $14 / 12 / 2009$ & (P2)Controle versus democratização. Artigo. Pág. 04. \\
\hline $15 / 12 / 2009$ & (P3)Foco é “controle social da mídia”. Matéria. Pág. 04. \\
\hline & (P4)Lula critica empresários que abandonaram a Confecom. Matéria. Pág. 06. \\
\hline $16 / 12 / 2009$ & (P5)Governo tenta isolar radicais na Confecom. Matéria. Pág.04. \\
\hline $16 / 12 / 2009$ & (P6)Lula chegou a ameaçar boicotar abertura da Confecom. Matéria. Pág.04. \\
\hline $16 / 12 / 2009$ & (P7)Confecom e o 'controle social' da mídia(i.e. censura). Editorial. Pág. 04. \\
\hline $17 / 12 / 2009$ & (P8)Confecom aprova propostas restritivas ao jornalismo. Matéria. Pág. 07. \\
\hline $17 / 12 / 2009$ & $\begin{array}{l}\text { (P9)Confecom sugere "controle social da mídia” e fiscalização do jornalismo. } \\
\text { Matéria. Pág. 06. }\end{array}$ \\
\hline $17 / 12 / 2009$ & (P10)Confecom aprova 'controle social' sobre a mídia. Matéria. Pág. 04. \\
\hline $17 / 12 / 2009$ & (P11)Confecom retoma Conselho Nacional de Jornalismo. Matéria. Pág. 05. \\
\hline $18 / 12 / 2009$ & (P12)Confecom pede “tribunal de mídia”. Matéria. Pág. 04. \\
\hline $20 / 12 / 2009$ & $\begin{array}{l}\text { (P13)Confecom retoma debate de controle social e propõe nova Lei de Imprensa. } \\
\text { Matéria. Pág. 06. }\end{array}$ \\
\hline $21 / 12 / 2009$ & (P 14)O saldo da Confecom. Editorial. Pág.05. \\
\hline
\end{tabular}

Quadro4: Síntese do conteúdo do jornal Folha de S. Paulo.

\begin{tabular}{|l|l|}
\hline \multicolumn{1}{|c|}{ Data } & \multicolumn{1}{|c|}{ Título } \\
\hline $14 / 12 / 2009$ & (P1)Confecom pede transparência em concessões. Matéria.Pág. A9. \\
\hline & (P2)Tribunal de mídia está entre as propostas de governo. Matéria. Pág. A9. \\
\hline & $\begin{array}{l}\text { (P3)Polêmica: Planalto diz que não há tema tabu e que não teme discussão. Matéria. } \\
\text { Pág. A9. }\end{array}$ \\
\hline & (P4)“Tribunal de mídia” está entre as propostas do evento. Matéria. Pág. A9. \\
\hline & (P5)Lula diz que defende imprensa livre, mas condena excessos. Matéria. Pág. A9. \\
\hline & (P6)Painel: De olho. Abert mandou observadores para a Confecom. Nota. Pág. A4. \\
\hline & (P7)A censura chegou ao próprio Supremo. Artigo. Pág. A8. \\
\hline $16 / 12 / 009$ & $\begin{array}{l}\text { (P8)Teles têm maior poder de voto em conferência de comunicação. Matéria. Pág. } \\
\text { A9. }\end{array}$ \\
\hline $18 / 12 / 2009$ & (P9)Confecom quer evitar emissora para político. Matéria. Pág. A13. \\
\hline $19 / 12 / 2009$ & (P10)Sindicatos rejeitam redução de impostos sobre banda larga. Matéria. Pág. A13. \\
\hline (P11)Confecom não atinge a mídia, afirmam empresa e ministério. Matéria. Pág. \\
A11. \\
\hline $21 / 12 / 2009$ & (P12)Painel: Tiroteio. Nota de deputado critica a Confecom e a TV Brasil. Pág. A4. \\
\hline $22 / 12 / 2009$ & (P13)Painel: Imprensa. Nota em que Lula elogia a Confecom. Pág. A4. \\
\hline $27 / 12 / 2009$ & $\begin{array}{l}\text { (P14)Painel: Registrar e punir. Nota critica “as cabeças do Governo Lula que } \\
\text { querem o controle social da mídia”. Pág. A4. }\end{array}$ \\
\hline
\end{tabular}


Quadro5: Síntese do conteúdo do jornal O Globo.

\begin{tabular}{|l|l|}
\hline 9/12/2009 & (P1)Liberdade de Imprensa. Artigo. Pág. 3. \\
\hline 9/12/2009 & (P2)Censura, nunca mais. Artigo. Pág. 4. \\
\hline 13/12/2009 & (P3)Fórum discute em Brasília produção de informação. Matéria. Pág. 4. \\
\hline 14/12/2009 & (P4)“Imprensa livre é fundamental para a democracia”, diz Lula. Matéria. Pág.10. \\
\hline $16 / 12 / 2009$ & $\begin{array}{l}\text { (P5)Confecom termina aprovando 672 propostas para a área de comunicação. Matéria. } \\
\text { Pág. 9. }\end{array}$ \\
\hline $16 / 12 / 2009$ & (P6)Imprensa ameaçada. Carta de leitor. Pág. 3. \\
\hline $17 / 12 / 2009$ & $\begin{array}{l}\text { (P7)Proposta aprovada na Confecom sugere criação de Conselho de Jornalismo. Matéria. } \\
\text { Pág. 10. }\end{array}$ \\
\hline $18 / 12 / 2009$ & (P8)Confecom aprova medidas restritivas ao jornalismo. Matéria. Pág. 9. \\
\hline $18 / 12 / 2009$ & (P9)Propostas desagradam entidades. Matéria. Pág. 9. \\
\hline $19 / 12 / 2009$ & (P10)Cartas marcadas. Editorial. Pág. 3. \\
\hline
\end{tabular}

Quadro6: Síntese do conteúdo do site do FNDC.

\begin{tabular}{|l|l|}
\hline \multicolumn{1}{|c|}{ Data } & \multicolumn{1}{c|}{ Assunto } \\
\hline $7 / 12 / 2009$ & (P1)Propostas para a construção de uma comunicação democrática. \\
\hline $8 / 12 / 2009$ & (P2)Marco regulatório da comunicação não deve sair nem em 2010. \\
\hline $8 / 12 / 2009$ & $\begin{array}{l}\text { (P3)Confecom: tema "controle social da mídia" não vai partir do Governo, garante } \\
\text { ministro. }\end{array}$ \\
\hline $11 / 12 / 2009$ & (P4)Confecom: regulação da internet e a radiodifusão, o centro da polêmica. \\
\hline $15 / 12 / 2009$ & (P5)Por um marco civil da internet: entrevista especial com Marcel Leonardi. \\
\hline $15 / 12 / 2009$ & (P6)Especialistas defendem liberdade de expressão e livre concorrência. \\
\hline $16 / 12 / 2009$ & (P7)Fenaj acusa imprensa de manter "pacto de silêncio" sobre a Confecom. \\
\hline $17 / 12 / 2009$ & (P8)Conferência sugere controle social da mídia e fiscalização do jornalismo. \\
\hline $17 / 12 / 2009$ & (P9)Sociedade civil, empresarial e Poder Público veem saldo positivo na \\
\hline $17 / 12 / 2009$ & Confecom. \\
\hline $18 / 12 / 2009$ & (P10)Setor empresarial trava embates com a sociedade civil na Confecom. \\
\hline $18 / 12 / 2009$ & (P12)Conferência propõe controle social da Comunicação. \\
\hline $18 / 12 / 2009$ & (P13)A grande mídia e a segunda Confecom. \\
\hline $18 / 12 / 2009$ & (P14)Para Abert, Confecom “ameaçou liberdade de imprensa". \\
\hline $18 / 12 / 2009$ & (P15)Para ANJ e Abert, resultado da Confecom é preocupante. \\
\hline $21 / 12 / 2009$ & (P16)Confecom: uma primeira vitória, uma nova etapa na longa luta. \\
\hline $21 / 12 / 2009$ & (P17)Resoluções indicam avanço para marco regulatório do Sistema Público de \\
\hline $21 / 12 / 2009$ & Comunicação. \\
\hline $21 / 12 / 2009$ & (P18)Bechara ressalta coragem e tolerância. \\
\hline $22 / 12 / 2009$ & (P19)Ceneviva: "Consumidor de comunicação foi grande vencedor na \\
\hline $22 / 12 / 2009$ & Confecom". \\
\hline $24 / 12 / 2009$ & (P20)Confecom: mudar a mídia. \\
\hline (P22)Confecom: construção coletiva de políticas públicas marca 2009. \\
\hline
\end{tabular}


Quadro7:Síntese do conteúdo do site Intervozes.

\begin{tabular}{|c|c|}
\hline Data & Assunto \\
\hline $15 / 12 / 2009$ & (P1)Foco é "controle social da mídia". \\
\hline $15 / 12 / 2009$ & (P2)Lula critica empresários por boicote à Conferência de Comunicação. \\
\hline $15 / 12 / 2009$ & (P3)Hélio Costa é vaiado na abertura da Conferência. \\
\hline $15 / 12 / 2009$ & (P4)Voto sensível leva à convocação de plenária da sociedade civil. \\
\hline $15 / 12 / 2009$ & (P5)Lula pede e CUT cede aos empresários na Confecom. \\
\hline $15 / 12 / 2009$ & (P6)Conferência da Comunicação avança com os três segmentos presentes. \\
\hline $15 / 12 / 2009$ & (P7)Azenha: Conferência de Comunicação "rompe" com a panelinha. \\
\hline $16 / 12 / 2009$ & $\begin{array}{l}\text { (P8)Representante da UIT defende livre concorrência para avanço das } \\
\text { telecomunicações. Assessoria de Imprensa/Confecom. }\end{array}$ \\
\hline $16 / 12 / 2009$ & (P9)Fugindo do debate. Luiz Egypto - Observatório da Imprensa. \\
\hline $16 / 12 / 2009$ & (P10)Palestrante argentino defende respeito legal à liberdade de expressão. \\
\hline $16 / 12 / 2009$ & (P11)Professor defende um marco regulatório. \\
\hline $16 / 12 / 2009$ & (P12)Inclusão digital é prioridade para o país, diz Lula na abertura da $1^{\mathrm{a}}$ Confecom. \\
\hline $16 / 12 / 2009$ & (P13)Começam votações de 1,5 mil projetos na Confecom. \\
\hline $16 / 12 / 2009$ & $\begin{array}{l}\text { (P14)Número de propostas para documento final é "surpreendente", diz organizador da } \\
\text { Confecom. }\end{array}$ \\
\hline $16 / 12 / 2009$ & (P15)Relatório final da Confecom proporá criação de Conselho Federal de Jornalismo. \\
\hline $16 / 12 / 2009$ & (P16)Discussões opõem empresários e movimentos sociais na Confecom. \\
\hline $17 / 12 / 2009$ & (P17)Confecom aprova resoluções importantes para as organizações sociais. \\
\hline $17 / 12 / 2009$ & $\begin{array}{l}\text { (P18)Primeira fase da Confecom aprova propostas democráticas. } \\
\text { Renata Mielli - Vermelho. }\end{array}$ \\
\hline $17 / 12 / 2009$ & (P19)Sobre a Confecom: essa Conferência é um marco para o País. \\
\hline $17 / 12 / 2009$ & $\begin{array}{l}\text { (P20)Controle social exige participação e mecanismos que garantam o direito à } \\
\text { Comunicação. }\end{array}$ \\
\hline $17 / 12 / 2009$ & (P21)Efetivação do sistema público é fundamental para o Intervozes. \\
\hline $17 / 12 / 2009$ & (P22)Intervozes lança vídeo sobre Direito à Comunicação. \\
\hline $17 / 12 / 2009$ & (P23)Vídeo reflete sobre o direito à Comunicação. \\
\hline $17 / 12 / 2009$ & (P24)Seminários apresentam propostas para indicadores do direito à Comunicação. \\
\hline $17 / 12 / 2009$ & $\begin{array}{l}\text { (P25)Comissões fazem críticas ao regimento interno e ao temário, mas seguem na } \\
\text { mobilização. }\end{array}$ \\
\hline $17 / 12 / 2009$ & (P26)Intervozes defende controle social em resposta ao Estadão. \\
\hline $17 / 12 / 2009$ & (P27)Conferência Nacional de Comunicação: um marco para a democracia no Brasil. \\
\hline $17 / 12 / 2009$ & (P28) ídeo reflete sobre o direito à comunicação no Brasil. \\
\hline $18 / 12 / 2009$ & (P29)Vitória: Confecom aprova o Conselho de Comunicação. \\
\hline $18 / 12 / 2009$ & $\begin{array}{l}\text { (P30)Confecom defende criação de conselhos de comunicação para emissoras públicas. } \\
\text { (Agência Brasil) }\end{array}$ \\
\hline $18 / 12 / 2009$ & $\begin{array}{l}\text { (P31)Brasil supera em } 4 \text { dias } 80 \text { anos sem debate na comunicação. Iram Alfaia - Portal } \\
\text { Vermelho. }\end{array}$ \\
\hline $18 / 12 / 2009$ & $\begin{array}{l}\text { (P32)Encerramento da Confecom é comemorado pelos movimentos. Anderson Bahia - } \\
\text { Portal Vermelho. }\end{array}$ \\
\hline $18 / 12 / 2009$ & $\begin{array}{l}\text { (P33)Conferência aponta novos rumos para a comunicação no Brasil. } \\
\text { Iram Alfaia - Portal Vermelho. }\end{array}$ \\
\hline $18 / 12 / 2009$ & (P34)Confecom rejeita Fust para Telebrasil e separação estrutural das redes. \\
\hline $18 / 12 / 2009$ & (P35)Confecom: rádios comunitárias devem ganhar mais canais. \\
\hline $18 / 12 / 2009$ & (P36)Plano Nacional de Banda Larga fica para 2010. \\
\hline
\end{tabular}




\begin{tabular}{|l|l|}
\hline Data & \multicolumn{1}{c|}{ Assunto } \\
\hline $18 / 12 / 2009$ & (P37)Confecom aprova por unanimidade banda larga em regime público. \\
\hline 18/12/2009 & (P38)Setores fazem balanço positivo da Confecom. \\
\hline 22/12/2009 & (P39)Divisor de águas entre a intolerância e o diálogo na Confecom. \\
\hline
\end{tabular}

A partir da delineação do objeto, exposto nos quadros acima, foi definida a abordagem teórico-metodológica e a pesquisa foi empreendida. São os procedimentos metodológicos oriundos da metodologia empregada - que guiam o pesquisador ao longo da investigação. Essa escolha tem a ver com as perguntas que são feitas ao objeto, e com os objetivos da pesquisa.

Optou-se por mesclar duas escolas de análise, de modo que uma complementasse a outra. Para isso, foram usados instrumentos metodológicos oferecidos pela Análise do Conteúdo, numa primeira etapa, e depois empregados os recursos da Análise do Discurso, de modo que o objetivo proposto fosse alcançado. Enquanto a Análise do Conteúdo, doravante AC, nos permite dissecar o material bruto, extraído dos jornais e dos sites, a Análise do Discurso, doravante $\mathrm{AD}$, nos permite ir além do conteúdo manifesto. 


\section{CAPÍTULO 4}

\section{ABORDAGEM TEÓRICO METODOLÓGICA}

Para dar conta de uma pesquisa que foi construída com o foco no discurso de pessoas, de entidades, de associações, de movimentos e de empresas - construído em um determinado período e em uma determinada circunstância - foi preciso ir além dos fatos e da história. Foi preciso ir na origem, buscar compreender onde tudo começou e como tudo se transformou no que hoje podermos chamar de discurso hegemônico do setor privado de mídia, e discurso contra hegemônico das entidades civis do movimento pela democratização dos meios.

Tudo o que foi analisado na presente investigação - entre editoriais, artigos, matérias e notas - tantos nos jornais como nos sites selecionados trata-se de discursos. Discursos que foram construídos no cenário da Confecom, ou em torno dela, e que foram expostos nos jornais e sites selecionados para a pesquisa. Discursos que quando manifestos reativam discursos outros que estavam em outros lugares e que são ressignificados quando lembrados.

O foco da pesquisa, portanto, não foi a Conferência em si, o que ela produziu, o que ela aprovou ou deixou de aprovar, e sim o que foi dito e o que foi silenciado pelos atores lá presentes. A Confecom criou uma rara oportunidade para que os dois lados da disputa pela comunicação pudessem confrontar suas posições com os seus opostos e fazer a defesa dos seus pontos de vista para toda a sociedade. Depois da Assembleia Nacional Constituinte de 1987/88 - quando estes dois lados da histórica luta pela democratização dos meios - se encontraram para discutir as bases da estrutura de comunicação do país, eles ainda não haviam se confrontado para tratar de uma pauta tão vasta que não deixou de fora nenhuma das polêmicas que afastaram estes dois segmentos no final da década de 80 .

A Confecom, por sua vez, que possibilitou este encontro histórico, acabou se transformando num duelo de discursos, onde cada um dos lados brigou para fazer prevalecer as suas posições. E foi sobre este aparato discursivo que a presente pesquisa se debruçou. A tese trata, pois, dos discursos que cada um dos lados construiu e manifestou - seja por meio dos três jornais pesquisados ou pelos dois sites ligados ao movimento social pela democratização da comunicação.

O discurso - peça medular neste trabalho - não é explicável em apenas uma definição. O discurso não existe solto ou isolado, ele pertence a alguém ou a um grupo, uma classe uma 
organização. É o discurso que constitui o sujeito como tal, é um efeito de sentido entre dois ou mais interlocutores. O discurso é o "lugar em que se pode observar a relação entre a língua e a ideologia" (ORLANDI, 2002).

"Na análise do discurso, procura-se compreender a língua fazendo sentido, enquanto trabalho simbólico, parte do trabalho geral, constitutivo do homem e da sua história" (ORLANDI, 2002, p. 15). A busca é pela linguagem enquanto discurso, pois este traz a significação ao texto. A análise não se interessa apenas pelo texto, mas este permite que o analista tenha acesso ao discurso.

E são exatamente os discursos que interessam. Nesta pesquisa, a noção de discurso vem da tradição francesa, mas a completude do seu significado não se encontra em apenas um conceito. Não se trata de discurso compreendido pelo senso comum, mas de discurso como prática da linguagem materializada, na relação que se estabelece entre a língua, a ideologia e o contexto histórico, político e social no qual foi construído. É difícil falar em “discurso" como um conceito isolado, de acordo com a formulação de M. Foucault, pois além de não dar conta de precisar todo seu sentido, ele ativa outros conceitos que serão aqui apresentados. Foucault constrói a seguinte definição:

Um conjunto de regras anônimas, históricas, sempre determinadas no tempo e no espaço, que definiram em dada época, e para uma área social, econômica, geográfica ou linguística dada, as condições de exercício da função enunciativa (FOUCAULT apud MAINGUENEAU, 2008, p. 16).

Mas essa definição ainda está aquém do sentido que é incorporado pelos construtos teóricos da Análise do Discurso, que se preocupa “em refletir como a linguagem está materializada na ideologia e como a ideologia se manifesta na língua" (ORLANDI, 2002, p. 16). Essa manifestação, certamente, se dá pelo sujeito, "não há discurso sem sujeito e não há sujeito sem ideologia" (PÊCHEUX, 1975) e, aí, finalmente, o sentido se completa:

...o sentido não existe em si, mas é determinado pelas posições ideológicas colocadas em jogo no processo sócio-histórico em que as palavras são produzidas. As palavras mudam de sentido segundo as posições daqueles que as empregam. Elas "tiram" seu sentido dessas posições, isto é, em relação às formações ideológicas nas quais essas posições se inscrevem (ORLANDI, 2002, p. 43). 
Assim como não há discurso sem sujeito, não há o discurso solto e sem endereço, todo o discurso pertence a um lugar de fala, e é este lugar que dá legitimidade à voz. É quando o discurso se materializa na linguagem. $\mathrm{O}$ embate que ocorreu na Confecom, mediado pelos jornais e sites nesta pesquisa, é revelador da marca ideológica que caracterizou cada um dos discursos estudados. Por exemplo, enquanto para os representantes das entidades sociais o "controle social da mídia" garante a liberdade de imprensa, que pode e deve ser garantida com a criação de órgãos e conselhos fiscalizadores. Para os representantes da mídia tradicional "o controle social é um eufemismo para subordinar o livre fluxo de informação aos interesses dos grupos organizados..." ${ }^{94}$. Cada segmento incorpora o conceito de acordo com seus interesses e ideias, ou seja, cada sujeito se apropria do conceito de acordo com a ideologia e o seu lugar no mundo.

Para as entidades sociais o lugar de fala é o lugar da defesa da liberdade de expressão, é o lugar daqueles que foram excluídos do direito de fala durante a longa ditadura militar vivida pelo país até 1985, e hoje este lugar é o lugar de quem está excluído dos grandes monopólios midiáticos brasileiros, o lugar das entidades sociais se situa no campo da sociedade civil não empresarial. Enquanto que para o setor privado de mídia o seu lugar é o lugar do poder, do comando, de quem controla os meios de comunicação, de quem monopoliza a informação, e que concentra poder em função da propriedade privada dos meios.

Para problematizar a analise do discurso em torno da Confecom - objeto da pesquisa foi preciso construir um suporte teórico que foi desde K. Marx até Manuel Castells, que discute os efeitos da internet na relação entre pessoas, e entre pessoas e o poder. Enfim, foi criada uma rede de sustentação conceitual para possibilitar a compreensão, não somente dos resultados encontrados, como também dos processos analisados e dos discursos presentes nos fatos selecionados para o estudo.

\subsection{As escolhas teóricas}

As escolhas teóricas que amparam a pesquisa têm a ver com as questões centrais que envolvem o seu objeto: o confronto de discursos hegemônico e contra-hegemônico construídos no cenário da Conferência Nacional de Comunicação, tendo de um lado o setor privado de mídia e do outro as entidades sociais que defendem a democratização dos meios de

\footnotetext{
${ }^{94}$ Foco é o controle social da mídia. O Estado de S. Paulo, 17/12/2009, p. 4.
} 
comunicação. Essas questões exigem a discussão de conceitos como sociedade civil, hegemonia e ideologia, observando como todas essas concepções estão inseridas na sociedade contemporânea, impactada pelo advento da internet e dos movimentos sociais da pósmodernidade.

Começar a problematização pelo entendimento do conceito de sociedade civil e hegemonia é a primeira decisão do referencial teórico. E isso é necessário para a compreensão da sociedade civil que temos hoje no Brasil e como ela se consolidou, uma vez que tratamos aqui de entidades que nasceram no seio desta sociedade. Junto com o amadurecimento da sociedade, ocorreu, paralelamente, o desenvolvimento dos aparelhos privados de hegemonia, instalados nos meios de comunicação, cuja importante parcela faz parte do foco desta investigação.

Uma vez que a pesquisa aborda a construção de discursos dos movimentos sociais organizados - que lutam pela democratização dos meios - e dos representantes da mídia tradicional, no cenário de uma Conferência Nacional, é preciso situar que, no contexto histórico em que o País se encontra, a hegemonia pelo controle da informação e dos meios de comunicação está instalada nas mãos do setor privado de mídia. Sendo assim, as entidades sociais buscam alterar esse poderio, a partir da construção de um discurso contra hegemônico que marque sua posição perante a sociedade de um modo amplo, e que essa luta ganhe espaço também dentro dos lares e no seio das famílias, não fique restrita aos meios acadêmicos e profissionais do segmento. O empresariado, por sua vez, também se apodera do espaço democrático da Conferência para defender suas posições.

Portanto, como a análise se deu no ambiente definido e recortado da Conferência Nacional de Comunicação, é fundamental compreender em que contexto esses discursos foram construídos e manifestados. Além disso, é preciso decifrar a hegemonia e ideologia presentes, para compreender o discurso tanto de um lado como de outro, e os entraves que impedem que se chegue a um consenso entre o setor privado de mídia e os movimentos sociais.

O impacto das mudanças tecnológicas, que transformaram definitivamente o campo da comunicação, foi fundamental para a discussão da influência da Internet sobre os meios, com foco no empoderamento dos atores que representam a sociedade civil organizada. Sendo assim, os estudos, pesquisas e reflexões de Manuel Castells foram fundamentais para esta discussão, bem como as análises sobre os movimentos sociais que estão se organizando na contemporaneidade com base nas pesquisas de Glória Gohn. 


\subsubsection{Hegemonia e sociedade civil}

O pensamento do italiano e militante comunista Antônio Gramsci, responsável pela ampliação da teoria marxista do Estado (elaborada por Marx e Engels) e pelo aprofundamento do conceito de hegemonia é que ajudou na compreensão desse conceito. A leitura de Carlos Nelson Coutinho, que melhor traduziu no Brasil a concepção de Gramsci sobre o Estado e a sociedade civil, foi obrigatória, entre outros pensadores.

O termo hegemonia veio emprestado do mundo militar. Vem do grego eghestai, que significa conduzir, e do verbo eghemoneuo, que quer dizer ser guia. Na Grécia Antiga, o termo era aplicado para qualificar o Exército que detinha a supremacia. Ao ser levado para o campo da Ciência Política, assumiu as nuances que hoje são observadas e aplicadas nos estudos sobre as relações de classe e de poder, dentro da sociedade moderna e contemporânea.

Quando a teoria marxista do Estado foi elaborada, no final do século XIX, o contexto histórico e social era de uma sociedade atrasada, quase primitiva, em que a força do Estado era proeminente e a formação de classe ainda incipiente, pois a concepção de sociedade civil ainda era restrita à esfera das necessidades particulares das pessoas de determinado lugar. Em termos bem simplificados, Gramsci elabora o que vem a ser de fato o conceito de sociedade civil, em contraponto ao conceito de sociedade política que, até então, era quase que equivalente ao conceito de Estado.

O conceito de sociedade civil é o meio privilegiado por meio do qual Gramsci enriquece, com novas determinações, a teoria marxista de Estado. Para o pensador italiano, a sociedade civil se afasta e se diferencia do aparato do Estado e começa a se colocar como um contraponto a este (COUTINHO, 1992). O Poder já não está totalmente nas mãos do Estado, mas começa a se instalar também em meio ao que não é Estado, o que Gramsci caracteriza como "aparelhos privados de hegemonia" (GRAMSCI, 1992).

Com os restritos aparelhos privados de hegemonia existentes na época em que Gramsci formulou sua teoria (sindicatos, clubes, igrejas, partidos) ele foi capaz de elaborar um pensamento que muito corretamente se aplica aos dias de hoje. Quando Gramsci faleceu, em 1937, depois de ter passado 11 anos preso, o rádio estava começando a surgir e ser considerado como o primeiro aparato dos meios de comunicação, apropriado pelo Poder, para o exercício da dominação. É sempre lembrado o exemplo do uso massivo do rádio, por Hitler, na Segunda Guerra Mundial, para implantar a ideologia do nazismo.

Hoje, certamente, identificamos nos meios de comunicação os modernos "aparelhos privados de hegemonia", sendo que no caso brasileiro, a TV Globo, e as suas demais 
empresas que se caracterizam como um clássico caso de propriedade cruzada, ocupam o primeiro lugar.

\begin{abstract}
As sociedades contemporâneas, nas quais os midia são os principais "construtores da realidade social", têm sido identificadas como possuidoras de "culturas midiáticas" (SCHMUCLER; MATA, 1992) e, embora existam diferenças significativas entre países, com relação ao consumo dos vários midia (impressos e eletrônicos), é inegável que ocupam uma posição central entre os contemporâneos "aparelhos privados de hegemonia" (LIMA, 1996)
\end{abstract}

A percepção da ação dos aparelhos privados de hegemonia, instalados nos meios de comunicação, permitiu, por exemplo, enxergar o papel exercido pelas organizações Globo no processo de transição da ditadura para a democracia,

$\mathrm{Na}$ condição de um órgão da sociedade civil, ou, aparelho privado de hegemonia, essas organizações são o lugar onde se disputa o controle ou a imposição dos interesses particulares de um grupo sobre toda a sociedade. Essa imposição, contudo, não se daria pelo uso puro da repressão, ao contrário, ela se impõe por meio da utilização estratégica, desses aparelhos privados para a divulgação de uma visão de mundo que corresponda à forma de dominação burguesa. Muito se discute sobre a importância de Gramsci para se pensar as estratégias de dominação burguesa no Brasil. A recente transição brasileira para a democracia se deu sob rigoroso controle militar. Entretanto, no término de cerca de duas décadas de regime autoritário, a sociedade brasileira lança-se na experiência democrática, por meio de vários episódios originados no início dos anos de 1980. O momento da transição também foi importante para se notar o grau de influência da mídia e de algumas empresas de comunicação nos destinos da Nação. A tentativa de manipulação política eleitoral da rede Globo nas eleições para governador da cidade do Rio de Janeiro, em 1982, ilustra um episódio concreto de uso de aparelhos privados de hegemonia para o controle do processo político pelas elites nacionais. (SILVA, 2011, p. 32).

Os aparelhos privados de hegemonia funcionam em favor da visão de mundo que uma fração das elites brasileiras quer impor à sociedade.

A rede Globo transformou-se em aparelho privado de hegemonia fundamental, funcionando no duplo papel de legitimadora do poder e, simultaneamente, exercendo-o amplamente no processo político brasileiro do período de 1982-1985. ...A rede Globo distorce, omite e promove informação com objetivo político. Foi assim nas eleições de 1982 no Rio de Janeiro; nas greves de Paulínia e do ABC em 1983; e ainda durante a campanha das Diretas-Já em 1984 (LIMA apud SILVA, 2011, p. 35). 
Esse episódio das eleições ao governo do Rio de Janeiro ${ }^{95}$, que acabaram elegendo Leonel Brizola, é apenas mais um entre tantos protagonizados pelo aparato do então proprietário do sistema Globo de Comunicação, Roberto Marinho, também mencionado neste estudo, de como a "rede Globo foi afinada com o Regime Militar, atuando quase como um monopólio, a partir da década de 1970" (SILVA, 2011, p. 32). Fica evidente a característica do sistema brasileiro patrimonialista, no qual o público se confunde com o privado, e o privado opera em nome do governo.

a rede Globo constituiu-se, ao longo dos anos [...], em 'agente de legitimação', fundamental para a nova composição do 'bloco histórico' que emergiu a partir de 1964-85, da mesma forma que desempenhou com eficiência e dedicação, esse mesmo papel, nos anos de 1970, na sustentação do regime autoritário (LIMA, 2001, p. 155).

No caso atual do cenário midiático brasileiro, com destaque para a Confecom, ficou muito claro o discurso hegemônico construído e manifesto pelos empresários de mídia, que se recusam sequer a discutir questões mais fundantes como a liberdade de expressão e de imprensa e a necessidade de fiscalização da atividade jornalística. Eles insistem em associar "o controle social da mídia" à censura. E as entidades ligadas ao movimento social pela democratização dos meios, apesar de terem construído um discurso contra hegemônico para confrontar "os donos da mídia" pouco avançaram no sentido de convencer a sociedade de que o controle irá garantir a prática da liberdade de expressão. Apesar do discurso, o movimento não conseguiu afastar o fantasma da censura.

\subsubsection{A coerção como elemento preponderante no exercício da dominação.}

Gramsci entende que Marx não poderia, na época em que viveu e teorizou sobre a organização do Estado, ter concepções mais avançadas de sociedade civil ou mesmo do aparelhamento do Estado: "a sua experiência era muito restrita e primitiva, ainda estava preso a um único conceito de organização, preso a elementos como organizações profissionais, clubes jacobinos, conspirações secretas de pequenos grupos" (COUTINHO, 1981, p. 90) e uma bem incipiente organização jornalística, como mostra o trecho a seguir:

Marx não podia, em suma, captar plenamente uma dimensão essencial das relações de poder numa sociedade capitalista desenvolvida: precisamente

\footnotetext{
${ }^{95}$ Neste episódio o proprietário da Rede Globo, Roberto Marinho, teria participada da tentativa de fraudar o resultado das eleições ao Governo do estado do Rio de Janeiro para impedir a vitória de Leonel Brizola.
} 
aquela 'trama privada' a que Gramsci se refere, e que mais tarde ele irá chamar de 'sociedade civil', de 'aparelhos privados de hegemonia', ou seja, os organismos de participação voluntários, e que não se caracterizam pelo uso da repressão (COUTINHO, 1981, p. 90).

Gramsci também conceitua "sociedade civil" como portadora material da figura social da hegemonia, esfera de mediação entre a infraestrutura econômica e o Estado em sentido restrito (COUTINHO, 1992, p. 121). Para Gramsci, o "Estado em sentido estrito" também denominado "Estado coerção" é entendido como "sociedade política" formada pelo conjunto dos mecanismos através dos quais a classe dominante detém o monopólio legal da repressão e da violência, e que se identifica com os aparelhos de coerção sob controle das burocracias executivas e policial militar. A outra esfera, presente na superestrutura, conforme Coutinho:

é a sociedade civil, formada precisamente pelo conjunto das organizações responsáveis pela elaboração ou difusão das ideologias, compreendendo o sistema escolar, as igrejas, os partidos políticos, os sindicatos, as organizações profissionais, a organização material da cultura (revistas, jornais, editoras, meios de comunicação de massa) etc. (COUTINHO, 1981, p. 91).

A teoria ampliada do Estado em Gramsci (conservação/superação da teoria clássica), por sua vez, apoia-se nessa concepção dos "aparelhos privados de hegemonia" que estão instalados no que Gramsci apropriadamente denominou como "sociedade civil" (COUTINHO, 1981):

... habitualmente, o Estado é entendido como sociedade política (ou ditadura, ou aparelho coercitivo para adequar a massa popular a um tipo de produção e à economia de um dado momento); e não como equilíbrio entre sociedade política e sociedade civil (ou hegemonia de um grupo social sobre a inteira sociedade nacional, exercida através de organizações ditas privadas, como a Igreja, os sindicatos, as escolas etc.)" (GRAMSCI apud COUTINHO, 1981, p. 91).

Ainda segundo Coutinho, nessa - então - nova abordagem de Gramsci,

os mecanismos de poder, portanto, não se limitam mais aos institutos de dominação direta, aos mecanismos de coerção. Embora eles continuem existindo, mas ao lado deles, Gramsci vê na emergência da sociedade civil ocorrer relações sociais de direção político-ideológica de hegemonia, que por assim dizer, completam a dominação estatal, a coerção, assegurando também o consenso, ou hegemonia para as forças que querem destruir a velha dominação (COUTINHO, 2000, p. 16). 
Na medida em que se vê o surgimento da sociedade civil, o Estado também passa por um processo de transformação, onde ele já não mais impõe uma religião ou sua visão de mundo em geral.

As instância ideológicas de legitimação passam a ser algo privado em relação ao público; a religião - por exemplo - deve conquistar consciências, deve confrontar-se, entrar em luta com outras ideologias... criam-se portanto portadores materiais dessas visões de mundo, o que Gramsci chamou de aparelhos privados de hegemonia. (COUTINHO, 2000, p. 18).

Segundo o professor Murilo Ramos, quando Gramsci cunhou este termo,

ele via a sociedade civil estruturada dessa forma, mas via nesses 'aparelhos' uma alternativa viável de produção de novas hegemonias emancipatórias, na medida em que subentendia um relativo equilíbrio entre esses aparelhos... Ele acreditava ser possível a produção de consensos emancipatórios pela via de uma cultura e de uma prática política revolucionária, ao alcance de um proletariado socialmente majoritário e politicamente educado, graças ao partido de massas - o moderno Príncipe. O que Gramsci não antecipou foi a rápida e progressiva modificação da imprensa; os jornais de opinião logo perderiam espaço acelerado para os jornais de massa, comerciais, e, em pouco tempo mais, século $\mathrm{XX}$ adentro, para um rádio e uma televisão igualmente massificados e ainda mais dominados pelo financiamento comercial atrelado ao consumo capitalista e por conteúdos de lazer catártico tão mais atraentes quanto fossem seus conteúdos ideológicos alienantes (MURILO, 2007, p. 37).

É este ponto da teoria gramsciana - aparelhos privados de hegemonia - que vai ao encontro do construto teórico desta pesquisa, que busca as raízes que explicam como o segmento empresarial da mídia brasileira estabeleceu sua hegemonia sobre a comunicação brasileira. Essa percepção é fundamental para que seja possível perceber como a teoria explica a realidade.

Por meio dos chamados "aparelhos privados de hegemonia", Gramsci (1981) desenvolveu seu entendimento sobre dominação, sem o uso de violência física ou repressiva, típica de Estado ditatorial e autoritário, como a Itália do fascismo, que ele conhecia de perto. A dominação, concebida por esse intelectual italiano, tem a ver com a que a elite dominante exerce sobre as classes inferiores, sem o aparato da força, mas com a difusão da ideologia que querem impor a outras classes, lançando mão de todo o sistema fora do Estado: igrejas, escolas, partidos políticos, sindicatos profissionais e os meios de comunicação.

Gramsci concentra seus estudos sobre o desenvolvimento da sociedade civil em contraposição à sociedade política (ou Estado-coerção) "que já havia recebido atenção 
prioritária dos clássicos" (COUTINHO, 1981, p. 92). Gramsci inova na medida que aprofunda a questão da hegemonia não mais como prerrogativa do Estado, mas "como uma figura social constituída numa base material própria, num espaço autônomo e específico de manifestação" (COUTINHO, 1981, p. 92).

\begin{abstract}
A esfera ideológica nas sociedades capitalistas, mais complexas, ganhou uma autonomia material, e não só funcional, em relação ao Estado em sentido restrito: a necessidade de conquistar o consenso ativo e organizado como base para a dominação - uma necessidade gerada pela ampliação da socialização da política - criou e/ou renovou determinadas objetivações sociais, que passam a funcionar como portadores materiais específicos (com estrutura e legalidade próprias) das relações sociais de hegemonia (COUTINHO, 1981, p. 91-92).
\end{abstract}

De acordo com Coutinho (1981), é exatamente essa "independência material - ao mesmo tempo base e resultado da autonomia relativa assumida atualmente pela figura social da hegemonia - que funda ontologicamente a sociedade civil como uma esfera própria, dotada de legalidade própria" (Idem, p. 93) que, por sua vez, também funciona como força de mediação necessária entre a estrutura econômica e o Estado-coerção. Nesse momento, Gramsci recupera a importância da estrutura na práxis marxista e corrobora as convicções de Marx, na medida em que reitera, concretamente, que "não há hegemonia, ou direção política e ideológica, sem as organizações materiais que compõem a sociedade civil enquanto esfera do ser social" (COUTINHO, 1981, p. 93). Gramsci, nesse momento, deixa claro que não despreza a importância da noção da estrutura de Marx como base material, e necessária para a materialidade do ser social.

A hegemonia, que passa a ser exercida pela classe dominante - por qualquer mecanismo -, obtém o consenso e a receptividade daqueles sobre os quais quer dominar. Esse consenso ou aceitação, pelos demais, é facilitado pelas ações dos aparelhos ideológicos, que, em outras épocas, em sociedades menos avançadas e complexas, era exercido pela Igreja e, hoje, nas sociedades contemporâneas, pode ser facilmente percebido nos meios de comunicação, nas mãos do empresariado privado. Mais uma vez, outro encontro da teoria e da realidade. Esse aspecto do construto teórico de Gramsci explica o que assistimos hoje na sociedade brasileira e que já foi explorado em diversos estudos sobre o uso dos meios de comunicação pelas classes dominantes.

É importante a presença da dominação pelo consentimento, presente nas classes dominantes, no exercício da hegemonia, valendo destacar que Gramsci não só aprofundou o 
conceito de hegemonia como instrumento do exercício de liderança como também inovou ao revelar a existência do que ele denominou de "consentimento dos de baixo", para que a dominação pela elite pudesse ser exercida com êxito (FEITOSA, 2007, p. 373). O pensador italiano defende a ideia da coerção como elemento preponderante no exercício da dominação.

Para o Estado exercer seu poder, sem o uso da violência pura e simples, conta não só com a coerção por meio dos seus aparatos como também pela ação dos aparatos de hegemonia do setor privado, que, por ideologia, obtém o consentimento e aceitação daqueles que são dominados. "A inovação pelo dirigente italiano consiste em sistematizar a ideia do poder como a soma dos elementos coerção e consentimento" (FEITOSA, 2007, p. 383).

Gramsci entende que para o Estado manter seu poder autoritário, unicamente pela força, os riscos de desmantelamento seriam incontornáveis. Teria de haver certa cumplicidade não explícita por parte dos dominados, ao que o pensador chama de "consentimento" da classe dominada, ainda que de modo inconsciente, como no trecho a seguir:

O exame do conjunto da reflexão teórica de Gramsci já demonstra a percepção bastante presente segundo a qual a força das classes dominantes, numa dada sociedade, não se apoia tão somente no controle da atividade econômica, mas também num complexo de iniciativas políticas, culturais e morais, com a finalidade de construir coesão em torno das iniciativas 'dos de cima' (FEITOSA, 2007, p. 388).

Não seria exagerado sugerir que, de certa forma, perceber a coerção no processo de dominação, apontada por Gramsci, está implícito em conceito que surgiu cerca de 50 anos após a morte do pensador desse italiano - é o conceito de "microfísica do poder" cuidadosamente desenvolvido pelo filósofo e sociólogo francês, Michel Foucault. Quando Gramsci conceituou "coerção e consentimento", estava se referindo ao que podemos chamar de estratégias usadas pela estrutura de poder para obter dos dominados a aceitação do domínio.

Pelos avanços no campo da Sociologia e da Ciência Política, podemos considerar que essas estratégias são imanentes às relações oriundas do poder. Segundo Foucault (1991):

o estudo dessa microfísica supõe que o poder nela exercido não seja concebido como uma propriedade, mas como uma estratégia, que seus efeitos de dominação não sejam atribuídos a uma "apropriação", mas a disposições e manobras, a táticas e técnicas, a funcionamento" (FOUCAULT, 1991, p. 29). 
Esse pesquisador desenvolveu profundos estudos sobre as estruturas estatais e paraestatais estabelecidas nas instituições controladas pelo Estado, como prisões, clínicas psiquiátricas penais e hospitais, nos quais afirmava que "o poder não é uma coisa, não favorece a um só grupo, suas armas podem vir de ataque e também de contra-ataque; é um regime de correlações de forças que circulam, sem possuir um caminho de fluxo, sem simetria aparente" (FOUCAULT apud PIMENTEL FILHO; VASCONCELOS, 2008, p. 451). Na concepção de Foucault, o poder deve ser analisado como algo que circula, ou melhor, como algo que só funciona em cadeia. Nunca está localizado aqui ou ali, nunca está nas mãos de alguns, nunca é apropriado como uma riqueza ou um bem. O poder funciona e é exercido em rede (FOUCAULT, 2008, p. 183).

Em estruturas estatais e paraestatais, o poder é exercido a partir de correlações de forças imanentes ao domínio a ser exercido. Todavia, explica o filósofo, o controle praticado no que ele chamou de "aparelhos de estado", é apenas a face exterior do poder e da dominação. A outra, que fica submersa nos controles internos e, talvez, por isso, mais eficaz, induz estados de poder que estão em constante movimento.

O poder não está, tão somente, no aparato do Estado ou nas mãos da elite dominante, mas é fruto de uma relação, é relacional, fruto das relações de poder estabelecidas. Nesse ponto, essas interpretações são parecidas com o pensamento de Castells, para quem o "código fonte" de qualquer sociedade está nas relações de poder.

Onde existe o poder também é encontrado o que se antepõe a ele, o que resiste à dominação, o contra poder. Para Gramsci, o poder e a dominação não estavam estruturados somente nos aparelhos repressores do Estado, mas na hegemonia construída na sociedade, pela cultura e pelo sistema de educação e/ou comunicação. Esse poder é obtido pela construção de significados e valores vindos daqueles que dominam a grande e poderosa estrutura da comunicação, em todas as suas manifestações.

Coutinho explica que Gramsci, ao "cunhar a expressão 'sociedade civil' para designar esses organismos ou aparelhos, se afasta terminologicamente de Marx" (COUTINHO, 1981, p. 91). Ao contrário, e como o próprio texto indica, ele parece aproximar-se de certo modo da terminologia de Hegel ${ }^{96}$, que introduzia na "sociedade civil" as "corporações", ou seja, associações econômicas que surgiam naquela época e que podiam ser vistas como formas primitivas dos modernos sindicatos, conforme Coutinho:

\footnotetext{
${ }^{96} \mathrm{Hegel}$, filósofo alemão, foi um dos pensadores mais importantes do século XVIII e teve forte influência sobre Marx.
} 
Mas a eventual derivação terminológica de Hegel não deve ocultar a novidade do conceito gramsciano: com ele, Gramsci expressa um fato novo, uma nova determinação de Estado, que não nega ou elimina as determinações registradas pelos "clássicos", mas representa - e Gramsci está consciente disso - um enriquecimento e um desenvolvimento das mesmas (COUTINHO, 1981, p. 91).

A realidade vivida por Gramsci, quando assistiu a desmoralização da revolução bolchevique na Rússia, em 1917, deu a ele elementos para fazer uma leitura inédita da "formação e ação das instituições liberais no contexto do que chamou de ocidente, contrapondo ao orientalismo da revolução comunista russa" (RAMOS, 2007, p. 33). Segundo Ramos (2007),

convencido da impossibilidade de ver ocorrer em seu país, bem como nos demais, o modelo de conquista revolucionária do Estado usado por Lênin na Rússia, Gramsci desenvolveu um pensamento político que tem na sociedade civil, no modo como ele a conceitua, um instrumento teórico de rara força e, friso, notável atualidade. (RAMOS, 2007, p. 33).

...tanto em Marx como em Gramsci a sociedade civil, e não mais o Estado, como em Hegel, representa o momento ativo e positivo do desenvolvimento histórico. De modo que em Marx esse momento é estrutural, enquanto em Gramsci é superestrutural. Em outras palavras; ambos colocam o acento não mais no Estado, como fazia Hegel, mas sobre a sociedade civil. Com a seguinte diferença, a inversão de Marx implica passagem do momento superestrutural ao momento estrutural, enquanto para Gramsci ocorre no interior da superestrutura. (BOBBIO, 1982, p. 33-34)

Para entender a evolução do conceito de sociedade civil, e voltando um pouco na história, Bobbio foi buscar as fontes inspiradoras de Hegel que, por sua vez, influenciaram Marx e Engels,

Adam Ferguson, juntamente com Adam Smith, é uma fonte de Hegel no que se refere à sociedade civil... Ferguson descreve a passagem das sociedades primitivas às sociedades evoluídas, é uma história de progresso. A humanidade passou do estado selvagem, sem propriedade e sem Estado, ao estado bárbaro dos povos que se iniciam na agricultura e introduzem os primeiros germes de propriedade, ao estado civil caracterizado pela instituição da propriedade, do comércio e do Estado... (BOBBIO, 2012, p. 48).

Ainda de acordo com Ferguson, a 'sociedade civil' é civil para se opor à sociedade primitiva e não porque se distingue da sociedade doméstica ou da sociedade natural. Só em 
Hegel é que o conceito é entendido de forma próxima ao que entendemos hoje, tendo sido aprofundado por Marx. Em palavras bem simplificadas, 'sociedade civil' seria tudo o que existe entre o lugar da família e do Estado. Segundo reitera Hegel, "tanto os Estados antigos quanto os despóticos e as repúblicas gregas não tinham uma sociedade civil, formação característica que surgiria na Idade Moderna" (HEGEL apud BOBBIO, 1987, p. 48).

O significado tradicional de sociedade, ainda preso às sociedades selvagens, bárbaras e, por fim, civis, só vai se diferenciar a partir da concepção de Hegel, para quem a sociedade civil faz parte do processo de formação do Estado. "Uma história completamente diversa começa com Hegel, para o qual, pela primeira vez, a sociedade civil não compreende mais o Estado na sua globalização, mas apenas um momento no processo de formação do Estado" (BOBBIO, 2012, p. 49).

Marx entende também que o sistema das necessidades constitui o primeiro momento da sociedade civil de Hegel, e que esta se situa "exclusivamente nas relações materiais ou econômicas" (BOBBIO, 2012, p. 49), que começa a se distinguir da esfera do Estado. Mas é só em Gramsci que a sociedade civil se distingue completamente da esfera do Estado e "desloca a sociedade civil da base material para a esfera superestrutural e dela faz o lugar da formação do poder ideológico distinto do poder político estritamente entendido e dos processos de legitimação da classe dominante" (BOBBIO, 2012, p. 49).

Esse deslocamento feito por Gramsci do conceito de sociedade civil da estrutura para a superestrutura, citado acima, foi muito polêmico entre os intelectuais comunistas, mas foi considerado mais adequado pelos estudiosos que revisaram as contribuições de Marx. Gramsci, contrariamente a Marx, entende que a sociedade civil pertence ao momento da superestrutura e não ao da estrutura, pois retira a sociedade civil da estrutura econômica (como aparece em Hegel e Marx) e a integra à superestrutura. Assim, a sociedade civil já não é, como em Marx, o momento das relações econômicas, mas das relações ideológicas, culturais, sociais e políticas.

Conforme Coutinho (1992), essa observação é importante e decisiva porque o conceito de sociedade civil é o meio privilegiado pelo qual Gramsci enriquece, com novas delimitações, a teoria marxista de Estado, ampliando-a com novas determinações.

Outro estudioso da obra de Gramsci, o militante italiano, comunista e intelectual Luciano Gruppi, complementa essa abordagem, com foco na questão da hegemonia que, por sua vez, opera sobre a superestrutura, conforme o trecho a seguir: 
o conceito de hegemonia em Gramsci é concebido numa visão de totalidade que se expressa na unidade entre estrutura e superestrutura, entre economia e política, na relação tensa entre direção e domínio, consenso e coerção, como também no campo das ideias e da cultura, quando se busca conquistar consensos e construir um bloco social capaz de realizar uma reforma intelectual e moral, como algo que não opera apenas sobre a estrutura econômica e sobre a organização política da sociedade, mas também sobre o modo de pensar, sobre as orientações ideológicas e inclusive sobre o modo de conceber (GRUPPI, 1991, p. 5).

\subsubsection{As contribuições de Norberto Bobbio}

Bobbio desenvolveu um conceito de sociedade civil que não é de esquerda nem de direita, mas é adequado à democracia representativa que temos. O fato de Norberto Bobbio não ter sido apenas um intelectual que teorizou sobre os direitos naturais do cidadão ou as liberdades negativas (as que defendem o indivíduo dos abusos do poder), mas por ter convivido durante cerca de 20 anos com o fascismo, faz com que suas teses sobre democracia liberal sejam bastante respeitadas e validadas. É dele a afirmação que "uma má democracia é sempre preferível a uma boa ditadura" (BOBBIO, 1987, p. 82).

A opção de Bobbio pelo que se pode chamar de "vertente liberal do liberalismo", ou "socialismo liberal", é baseada no que ele considera fundamental em uma democracia, que é “a luta pela constitucionalização dos direitos naturais, pela afirmação das liberdades negativas, que afirmam a variedade individual perante as intenções uniformizadoras do Estado" (BOBBIO, 1998).

A via defendida por Bobbio é um encontro entre o que o socialismo tem de melhor, em relação aos direitos sociais do cidadão, e o que a democracia tem de melhor, que é a defesa intransigente da liberdade, dos direitos individuais e da igualdade entre os cidadãos, de acordo com o texto:

Bobbio se bateu pela defesa da continuidade, no mundo pós-queda do Muro de Berlim, da distinção ideológica entre direita e esquerda a partir de um critério central: a postura diante do ideal de igualdade, a avaliação da relação entre igualdade-desigualdade natural e igualdade-desigualdade social: $\mathrm{o}$ igualitário parte da convicção de que a maior parte das desigualdades que o indignam, e que gostaria de fazer desaparecer, são sociais e, enquanto tal, elimináveis; o inigualitário, ao contrário, parte da convicção oposta, de que as desigualdades são naturais e, enquanto tal, inelimináveis" (BOBBIO apud MONDAINI, 2001). ${ }^{97}$

\footnotetext{
${ }^{97}$ Disponível em: <http://www.artnet.com.br/gramsci/arquiv199.htm>.
} 
Nos estudos de Bobbio fica claro que sua preocupação central era que a garantia da democracia e dos direitos civis dos cidadãos fosse assegurada por "um governo das leis" e não “dos homens". Que a lei de um país fosse o mecanismo garantidor da democracia e que as regras do jogo estivessem estabelecidas para serem seguidas, conforme o trecho a seguir:

As normas constitucionais são normas de procedimentos que servem para fixar o caminho de uma decisão - elas determinam o como e não o conteúdo da decisão a ser tomada -, já que o conteúdo está relacionado às opções políticas vencedoras do jogo (BOBBIO, 1987, p. 255).

Os estudos de Bobbio mostram uma "visão liberal sobre Gramsci" e trouxeram inovação mais adequada ao conceito de democracia do que a construída por Marx, embora este seja seu inspirador. Sem entrar na polêmica que surgiu depois que Gramsci defendeu que a sociedade civil faz parte de uma superestrutura, e não de uma estrutura, como concebeu Marx, o fundamental é entender que Bobbio considera sociedade civil e Estado como dois termos de antítese, ausente, portanto, da concepção de um Estado ampliado, conforme a seguir:

A contraposição entre sociedade e Estado que alça voo com o nascimento da sociedade burguesa é a consequência natural de uma diferenciação que ocorre nas coisas e, ao mesmo tempo, de uma consciente divisão de tarefas, cada vez mais necessária, entre os que se ocupam da "riqueza das nações" e os que se ocupam das instituições políticas, entre a economia política num primeiro tempo e a sociologia num segundo tempo, de um lado, e a ciência do Estado com todas as disciplinas afins, como a ciência da Administração e outras (BOBBIO, 2012, p. 51).

\subsubsection{A sociedade civil no Brasil}

$\mathrm{Na}$ avaliação do professor Murilo Ramos, que também escreveu sobre a "a importância de se repensar a ideia de sociedade civil” (2007):

O movimento brasileiro pela democratização da comunicação, nascido durante a ditadura militar e que teve na hegemonia comercial e política das Organizações Globo a sua motivação inicial de luta - o que de certo modo ocorre até hoje - sempre assentou sua base social no que se convencionou chamar de sociedade civil. Enquanto durou a ditadura militar, essa sociedade era facilmente reconhecível, e se identificava, pluralisticamente, com aquela mais ampla, que se opunha à sociedade militar. Uma era do bem, outra do mal, em uma polaridade típica dos anos 60,70 e 80 do século $\mathrm{XX}$, sob a égide da Guerra Fria, em que esquerda e direita, comunismo e capitalismo, socialismo e liberalismo davam as direções e palavras de ordem com as quais se ia à luta. Essa sociedade civil organizava-se ao longo de linhas 
essencialmente corporativas: sindicatos e associações de trabalhadores, sindicatos associações empresariais, associações profissionais liberais, representações de estudantes e professores (MURILO, 2007, p. 43)

Especialmente a partir do final da Ditadura, portanto, a sociedade civil começa a se fortalecer, tanto a empresarial como a social, e ambas comungam de bandeiras semelhantes como a luta por eleições diretas, o pluripartidarismo, a liberdade de imprensa, a redução da miséria, a melhoria do ensino e da saúde. Um pouco mais tarde é que as organizações populares se afastam e criam entidades mais distintas e fortes como o novo sindicalismo, a fundação do PT, a criação da CUT e de outras organizações civis, como o MST e as comunidades eclesiais de base (ligadas à Igreja progressista), e outras menores, mas não menos importantes, como o FNDC e o Coletivo Intervozes, que encamparam a luta pela democratização dos meios de comunicação.

Do lado empresarial também surgiram fortes e importantes organizações como a Federação das Indústrias de São Paulo (Fiesp), a Confederação Nacional da Indústria (CNI), a Confederação Nacional da Agricultura (CNA) e outras. Nesse contexto, cada um desses lados "atua tanto para manter a hegemonia de sua classe sobre outras quanto para manter o domínio do aparelho do Estado" (GOULART, 2007, p. 71).

Configura-se, de fato, uma luta pela hegemonia e pelo poder dentro da sociedade civil, lembrando que no caso brasileiro o empresariado sempre teve garantido seu espaço de influência e de atuação junto ao Estado. As entidades sociais, por sua vez, também buscam o apoio dos seus pares para ganhar aliados na luta pelos seus objetivos, por meio do convencimento ou da identificação de ideais. A classe dominante no País, que detém o monopólio sobre os meios de comunicação, também se apropria de mecanismos de coerção e de convencimento, para fazer prevalecer sua posição ideológica.

A disputa que se dá entre sociedade civil não empresarial e o empresariado não chega a se configurar como "uma tradicional luta de classes", embora exista como tal, só que reconfigurada. O mais adequado é usar o termo gramsciano "guerra de posição" para explicar essa briga por espaços. Segundo Coutinho,

o centro da luta de classe está na "guerra de posição", numa conquista progressiva ou processual de espaços no seio e por meio da sociedade civil, visando à conquista de posições... esta seria uma condição para o acesso ao poder de Estado e para sua posterior conservação (COUTINHO, 1999, p. 155). 
Para traduzir esse entendimento conceitual para a realidade que se instaurou no universo da luta pela democracia dos meios de comunicação no Brasil, fica claro que a sociedade civil empresarial carrega em si a hegemonia sobre a Comunicação, que é oferecida à sociedade brasileira. Os grupos antagônicos, reunidos nas entidades sociais que representam a resistência a essa Comunicação, buscam construir um discurso contra-hegemônico a esse modelo comunicacional que é imposto.

O Estado, por sua vez, especialmente a partir do Golpe Militar de 1964 e, depois, por meio dos governos neoliberais que governaram até 2002, assume a defesa dos interesses desse grupo dominante. "Nas palavras de Gramsci, o Estado é, certamente, concebido como organismo próprio de um grupo destinado a criar as condições favoráveis à expansão máxima desse grupo" (GOULART, 2007, p. 78). ${ }^{98}$

Por causa do distanciamento do Poder Público da sociedade, podemos identificar no País um modelo de sociedade civil que, nitidamente, distingue-se da sociedade política e guarda semelhança com o conceito de sociedade civil revisto por Habermas e discutido por Rebouças. Para Rebouças, revisando seu conceito de espaço público e atualizando o que Marx havia dito sobre a composição da sociedade civil para uma visão mais gramsciana, exclui as entidades ligadas ao mercado de trabalho ou à economia. Com isso, essa sociedade é formada por associações e organizações não governamentais e não econômicas, com características de voluntariado (REBOUÇAS, 2011).

A sociedade civil é formada por essas associações, organizações e movimentos que acolhem, condensam e repercutem, amplificando no espaço público político a ressonância que os problemas sociais encontram na esfera da vida privada. O coração da sociedade civil é, portanto, constituído por um tecido associativo que institucionaliza no âmbito dos espaços públicos organizados as discussões que se propõem a solucionar os problemas que surgem ligados a temas de interesse geral (HABERMAS, 1997 apud REBOUÇAS, 2011).

O modelo de sociedade civil que temos hoje no Brasil, onde as entidades e associações de classe estão em processo de fortalecimento, onde há evidente crise de representatividade dos partidos políticos, é propício para aumentar o empoderamento de quem pode falar em nome de comunidades ou grupos organizados que se reúnem e se organizam como movimento social, como o da democratização dos meios de comunicação, embora essa seja uma bandeira que ainda não foi adotada por boa parte da sociedade. Apesar de o Brasil ser um país que tem

\footnotetext{
${ }^{98}$ Artigo de Débora Goulart. Disponível em: <http://www.pucsp.br/neils/downloads/pdf_19_20/6.pdf>. Acesso em: 15 mar. 2014.
} 
reduzido a cada ano a exclusão digital, e de ser um dos países com maior número de celulares em relação à população, essa mesma população - tão conectada - não tem interesse de discutir os próprios mecanismos de acesso à comunicação.

Sendo assim, Rebouças acredita que a criação de observatórios de mídia com agentes preparados e envolvidos para trabalharem junto à sociedade para "incentivar a reflexão sobre a atuação da mídia e a participação nas ações em prol da democratização dos processos comunicacionais" (REBOUÇAS, 2011).

$\mathrm{Na}$ medida em que esse Estado não se empenha no sentido de buscar junto ao Congresso Nacional a regulamentação dos artigos que fazem parte do texto constitucional do capítulo da Comunicação, e tampouco evita que os grupos empresariais do setor aumentem seu poderio com a consolidação dos seus oligopólios, podemos afirmar que ele seja, no mínimo, conivente.

A partir de 2003, quando foi eleito pela primeira vez na história do País um presidente de um partido considerado de esquerda, esperava-se que esse conjunto de forças fosse alterado e que essa hegemonia do setor privado midiático fosse abalada. Todavia, apesar de alguns avanços modestos, como a criação da TV pública, é notório que a democracia sobre os meios de comunicação não apresentou avanços expressivos, como está exposto no artigo que o professor e pesquisador Venício Lima escreveu sobre o estado de arte da comunicação no País durante os 10 anos do governo petista (SADER, 2013). Esse tema, porém, será tratado adiante, no capítulo da contextualização da pesquisa.

\subsubsection{A ideologia}

A ideologia é um desses conceitos que são medulares para a compreensão tanto da história como da política de uma nação, de um povo ou de um pequeno grupo organizado, ou não, da sociedade civil. É um conceito que se faz presente em, praticamente, todas as teses das Ciências Sociais, e no caso desta pesquisa não é diferente. Como o foco da análise deste estudo recai sobre a construção de discursos na esfera midiática, a ideologia, necessariamente tem de ser problematizada e compreendida. Do ponto de vista discursivo, é por meio da ideologia que se consegue desvelar sentidos ocultos e até mesmo obnubilados presentes nos discursos em análise neste estudo.

Ao partir da noção deste conceito elaborado por Marx, que entende "a ideologia como um processo pelo qual as ideias da classe dominante tornam-se ideias de todas as classes sociais" o presente trabalho tentar desvendar porque os autores dos discursos empregados pela 
classe hegemônica - na questão da realidade midiática brasileira - dizem o que dizem. E como constroem um discurso que faz parecer que todos pensam da mesma forma.

Segundo interpretação da filósofa, Marilena Chauí, os homens produzem ideias ou representações pelas quais procuram explicar e compreender sua própria vida individual, social e até suas relações com o natural e o sobrenatural. Eles acreditam que suas vidas são o que são em decorrência de ações alheias à sua vontade; sendo decorrentes da natureza, de um poder divino superior ou do Estado, e que não têm poder sobre elas. Sendo, portanto, legítimo e legal que se submetam à essa realidade. Este é o trabalho realizado pela ideologia, que faz com que o ser humano acredite nisso, "a ideologia, simplesmente, cristaliza em 'verdades' a visão invertida do real" (CHAUÍ, 1996, p. 96).

Naturalmente, há uma outra força - segundo a concepção marxista do conceito - que é o fenômeno da alienação. Este fenômeno faz com que homem considere que suas reais condições de vida não são produzidas por ele, pelo contrario, ele é resultado destas condições e a elas deve se submeter. Com este convencimento, as ideias quotidianas dos homens representam a realidade de modo invertido e essa inversão é preservada, vindo a constituir os pilares para a construção da ideologia.

Um exemplo bem simples, trazido por Marilena Chauí, ilustra melhor essa ilusão do real.

Quando se diz que o trabalho dignifica o homem e não se analisam a as condições reais de trabalho, que brutalizam, entorpecem, exploram certos homens em benefício de uns poucos. Estamos diante da ideia de trabalho, e não diante da realidade histórico-social do trabalho (CHAUÍ, 2001, p. 97).

A ideologia com esta concepção é adequada para o contexto da luta de classes, em cujo esteio Marx se apoiou para elaborar essa percepção. Uma vez que, no âmago da luta de classes, a classe dominante se apodera da ideologia para submeter a classe dominada aos seus interesses. Para que uma classe explore economicamente a outra, e mantenha os seus privilégios, ela precisa de dois instrumentos, o Estado e a ideologia.

Através do Estado, a classe dominante monta um aparelho de coerção e de repressão social que lhe permite exercer o poder sobre toda a sociedade, fazendo-a submeter-se às regras políticas. E o Estado, por sua vez, tem em suas mãos o poder das leis, que no contexto em questão, faz com que as leis regulem as relações sociais a favor dos dominantes. 
Quando não são as leis que regulam a favor da classe dominante, ocorre a ausência da lei que acaba atuando da mesma forma. A não regulamentação dos artigos 221, 222 e 223, do Cap. V da Constituição Federal acaba por perpetuar uma situação de dominância do setor privado de mídia sobre o campo da comunicação. Enquanto os movimentos sociais defendem que estes artigos sejam regulamentados para que o direito à comunicação plena no Brasil esteja garantido, os empresários de mídia alegam que a liberdades de expressão e de imprensa já estão asseguradas sem a necessidade de qualquer intervenção por parte do Governo ou do Congresso Nacional.

Esse jogo de palavras, que evidencia o encobrimento das reais posições e intenções do empresariado ficou claro - no cenário da Confecom. O jornal O Estado de S. Paulo afirmou que a Confecom defendia a tese do controle social da mídia com a criação de conselhos de comunicação e que isso seria inconstitucional. "O risco real e presente é que a hora seja ajustada para marcar a guinada autoritária que seus adeptos tentaram instituir no primeiro mandato de Lula, com o projeto chavista do Conselho Federal de Jornalismo..."99. Ocorre que a própria Constituição prevê a criação de um conselho de comunicação.

Da mesma forma, o presidente da Associação Nacional de Editores de Revistas (Aner) Roberto Muylaert, também se pronunciou: “um controle social da mídia pressupõe mudança na Constituição, que atualmente assegura a livre iniciativa" ${ }^{100}$. Quando de fato, isso não seria necessário, uma vez que a luta das entidades sociais é exatamente pela regulamentação daquilo que já está no texto constitucional. A marca ideológica do encobrimento do real pensamento do empresariado se evidencia quando se percebe que, estes mesmos empresários não querem obedecer ao texto constitucional, mesmo que publicamente façam essa defesa da Constituição com um discurso conveniente.

No jornal $O$ Globo, mais um exemplo: as entidades que deixaram a Conferência declararam ao jornal que "o controle social da mídia é uma forma de censurar os órgãos de imprensa cerceando a liberdade de expressão, o direito à informação e a livre iniciativa, todos previstos na Constituição ${ }^{101}$. Estes atores, que representam os "donos da mídia” foram os mesmo que em 1988 tentaram impedir que o debate da Sub Comissão de Comunicação aprovasse os artigos que previam o impedimento para a formação de monopólios e a propriedade cruzada.

\footnotetext{
${ }^{99}$ Confecom e o 'controle social' da mídia, O Estado de S. Paulo, 16/12/2009, p. A6.

${ }^{100}$ Confecom e o 'controle social' da mídia, O Estado de S. Paulo, 16/12/2009, p. 5.

${ }^{101}$ Proposta aprovada na Confecom sugere criação de Conselho de Jornalismo, O Globo, 17/12/2009, p. 11.
} 
Para combater a ideia da necessidade de controle dos monopólios de mídia, um articulista do jornal $O$ Globo, afirmou que "se alguns grupos concentram muito poder por conta do seu tamanho, então a solução é mais competição e não mais governo". ${ }^{102}$

O jornal O Estado de S. Paulo, na edição do segundo dia do evento, afirmou - sem citar fontes - que:

os participantes da $1^{\text {a }}$ Conferência de Comunicação pregam o 'controle social' da mídia - um eufemismo para subordinar o livre fluxo da informação aos interesses dos grupos organizados, que dizem representar a sociedade e incentivam a ingerência do Estado no setor. ${ }^{103}$

Quando as entidades ANJ e Abert "condicionaram suas participações na Conferência à retirada do temário de qualquer proposta contrária à Constituição e receberam uma negativa o destino da reunião estava traçado". Esta afirmação é do jornalista Ricardo Noblat, em editorial no jornal $O$ Globo. Mais um véu para encobrir a verdade, uma vez que os proprietários de mídia, ao longo dos últimos vinte e cinco, se empenham para que essa mesma Constituição seja desrespeitada, e que os seus preceitos como controle da concessão de outorgas, "o estabelecimento de meios legais que garantam à pessoa e à família a possibilidade de se defenderem de programas ou programações de rádio e televisão que contrariem o disposto no art. 221, bem como da propaganda de produtos, práticas e serviços que possam ser nocivos à saúde e a meio ambiente" (CF, art. 220) sejam permanentemente esquecidos.

Sob o frequente argumento de que defendem a liberdade de expressão e de imprensa, os empresários escondem que, na verdade, defendem é a liberdade empresarial de manter o controle da informação e usar essa informação para manipular a opinião pública e garantir os seus oligopólios e sua permanente influencia junto ao Governo, qualquer que seja ele.

\subsubsection{Ideologia em Thompson}

$\mathrm{Na}$ atualização e reconfiguração do conceito, introduzidas por John Thompson (1995), ele conserva a essência do conceito marxista, segundo a qual, "a ideologia é sempre um

\footnotetext{
${ }^{102}$ Censura nunca mais, $\boldsymbol{O}$ Globo, 9/12/2009, p. 5.

${ }^{103}$ Foco é 'controle social da mídia', O Estado de S. Paulo, 15/12/2009, p. 6.
} 
sentido a serviço do poder" (THOMPSON, 1995, p. 16). Na tentativa de não excluir o que ele chamou de "sentido negativo do conceito", Thompson mantém a percepção de que,

o conceito de ideologia pode ser usado para se referir às maneiras como o sentido (significado) serve, em circunstâncias particulares para estabelecer e sustentar relações de poder que são sistematicamente assimétricas - que eu chamarei de 'relações de dominação'(Idem, p. 17)

E porque isso acontece? Porque "a ideologia é um dos meios mais eficientes usados pela classe dominante para exercer a dominação, fazendo com que esta ação não seja percebida como tal pelos dominados" (CHAUÍ, 2001, p. 94)

Todavia, as relações de classe - centrais no marxismo - na percepção de Thompson (1995), são apenas formas de dominação e subordinação, mas não são as únicas. Para Marx, a transformação dessas relações de classe, que formam o eixo estrutural das sociedades modernas, seria a chave para um futuro livre de toda dominação. "Vivemos, atualmente, em um mundo em que a dominação e subordinação de classe continuam a desempenhar um papel importante, mas que outras formas de conflito são prevalentes e, em alguns contextos de importância igual ou até maior" (THOMPSON, 1995, p. 78).

John Thompson também afirma que o sentido das formas simbólicas que está inserido nos contextos sociais e em circulação pelo mundo serve para estabelecer e sustentar relações de dominação e poder, que hoje estão muito mais sofisticadas e complexas. O pesquisador aponta como "formas simbólicas" um amplo espectro de ações e falas, imagens e textos que são produzidos por sujeitos e reconhecidos por eles e outros como construtos significativos (THOMPSON, 1995).

Naturalmente, no tempo em que Marx viveu e elaborou sua teoria, seria quase impossível imaginar a complexidade das formas simbólicas e midiáticas que tomariam forma no mundo contemporâneo e a maneira como seriam apropriadas pelas classes hegemônicas como elemento de dominação, pressão e coercimento.

Thompson (1995) define assim seu conceito de ideologia:

como o sentido mobilizado pelas formas simbólicas, serve para estabelecer e sustentar relações de dominação: estabelecer, querendo significar que o sentido pode criar ativamente e instituir relações de dominação; sustentar, querendo significar que o sentido pode servir para manter e reproduzir relações de dominação através de um processo de produção e recepção de formas simbólicas (THOMPSON, 1995, p. 79). 
Esse tipo de dominação - pela sutileza das formas simbólicas -, especialmente a partir do aparato midiático e tecnológico que as classes dominantes dispõem atualmente, corrobora o que Thompson quer defender. Segundo o pesquisador,

relações estabelecidas de poder são 'sistematicamente assimétricas' quando grupos particulares de agentes possuem poder de maneira permanente, e em grau significativo - permanecendo inacessível a outros agentes, independentemente da base sobre a qual tal exclusão é levada a efeito (THOMPSON, 1995, p. 80).

O sistema de comunicação, com certeza, é um aparelho ideológico que exerce esse papel, indicado por Thompson, na medida em que dissemina valores, códigos, condutas e visões de mundo de uma classe detentora do poder econômico e político que, por sua vez, exerce uma relação hegemônica sobre os meios. No caso do Brasil, o desequilíbrio entre as relações de poder foi determinante para o nascimento da nossa radiodifusão, entregue apenas à iniciativa privada que, ao longo do tempo, tornou-se mais concentrada e excludente (RAMOS, 2007).

$\mathrm{Na}$ esteira desta percepção, e com o foco na centralidade da mídia na sociedade contemporânea, é perceptível o processo de reprodução da vida social, e o eterno jogo de poder na busca da hegemonia de uma classe sobre a outra, "são hegemônicos os intelectuais que fazem a apologia - direta ou indiretamente - do poder existente no campo da comunicação" (COUTINHO, 2008, p. 8). Fazendo uma ilação ao pensamento de Gramsci, "há os que compreendem a cultura como uma instância de luta política, e os meios de comunicação como instrumentos de hegemonia por meio dos quais uma classe ou fração de classe impõe sua liderança intelectual e moral sobre o conjunto da sociedade” (Idem, p. 9)

Essa prevalência, apontada por Coutinho, pode ser vista no domínio que se observa hoje da comunicação - nas mãos dos mesmos grupos que sempre detiveram a supremacia da informação e desenvolveram com o Estado uma relação de favoritismo e subserviência de ambos os lados. Enquanto que, sob a perspectiva gramsciana, é possível prever "a possibilidade de grupos subalternos constituírem uma visão de mundo capaz de resistir e se contrapor às ideias dominantes. A essa resistência político-cultural é que Gramsci chamaria contra hegemônica." (COUTINHO, 2008, p. 10)

Que é exatamente o que foi percebido nos discursos manifestos das entidades sociais que, historicamente, lutam pela democratização dos meios. Segundo Coutinho (2008), há um reconhecimento, entre os intelectuais e estudiosos da questão da comunicação que, apesar do 
poder midiático dos grandes grupos e corporações mundiais, e da extrema capacidade da mídia de "criar o consenso necessário à dominação do capital” (Idem, 10), é possível identificar, no seio da sociedade civil, iniciativas e "experiências culturais e comunicacionais de resistência, contestação e pressão". Recentemente no Brasil, durante as manifestações de rua em junho de 2013, foi possível assistir ao fenômeno do "midiativismo", onde grupos, por meios das redes sociais, criavam e divulgavam informações sobre o que acontecia nos protestos.

Negar ou simplesmente ignorar a existência histórica da luta de classes, já é um sintoma de que a ideologia, conforme percebida por Marx, exerceu com competência os seus atributos:

abstrair esse fato (o da luta de classes) já é por si só um claro indício de como interesses e posições de classe podem coagir, ideologicamente, as formas de consciência, o universo da linguagem e da interlocução e a própria produção e circulação social do conhecimento no interior da sociedade e do Estado de classes (DANTAS, 2008, p. 91)

Na história da sociedade e do Estado quem dominava os meios de produção era, pois o dono do capital era quem detinha o poder, e a classe a qual pertencia exercia o domínio sobre as classes subalternas. Com a evolução e com a sofisticação das forças produtivas e do próprio capitalismo, a classe que controlava os meios de produção também passa a controlar a produção intelectual e social do conhecimento, e usa deste arcabouço para fazer prevalecer a sua hegemonia. "Como classe social dominante ela reúne - na contemporaneidade - todos os meios essenciais que fazem dela o poder material, espiritual e político hegemônico numa determinada sociedade" (DANTAS, 2008, p. 93).

O que torna mais desigual essa disputa, na atualidade, e descola a capacidade de geração de uma força contra hegemônica para as classes sociais mais desprovidas de renda é exatamente o capital do conhecimento, que por sua própria natureza capilar, não é totalmente controlado pela classe dominante, e penetra desgovernadamente em outras camadas da sociedade. Aliado a isso, entra o poder da tecnologia que, atropela barreiras sociais e empodera o cidadão que, historicamente, sempre ficou à margem da sociedade de consumo e de poder.

Todavia, hoje a disputa é ainda mais sofisticada e pesada do que outrora, porque os disfarces e o alcance dos mecanismos ideológicos são mais difíceis de serem identificados e barrados, uma vez que estão interiorizados nas práticas e ideias disseminadas pelos meios de 
comunicação especialmente no tempo livre que o indivíduo tem para o lazer e demais práticas sociais de convivência.

Na ordem social dominada pela produção capitalista de mercadorias, a classe trabalhadora já não pode mais ser tratada exclusivamente como fator objetivo de produção e como base da extração direta da mais-valia, a qual devem ser asseguradas tão-só as condições mínimas de subsistência. Passada a fase de acumulação primitiva do capital, sua reprodução ampliada, tomando a forma da produção e do consumo sempre ampliados, exige que proletariado possa vir a consumir a massa crescente de mercadorias que o capitalismo produz. Se o proletariado continua a existir fora da produção, é preciso que também seu tempo livre possa fazer parte do processo de reprodução ampliada do capital: o regime alienante que se impõe no espaço/tempo da produção deve se impor igualmente no espaço/tempo do lazer, que deve se tornar espaço/tempo do consumo (DANTAS, 2008, p. 96).

Hoje, a realidade - que é soberana - mostra que a ideologia se metamorfoseou e assumiu novas configurações sem, conduto, negar a sua essência: a de mobilizar pelas formas simbólicas, ou não, o sentido e o significado para estabelecer e sustentar relações de poder que são sistematicamente assimétricas, que podem ser chamadas de 'relações de dominação'. (THOMPSON, 1995, p. 116)

\begin{abstract}
A ideologia não é, simplesmente, uma representação falsa, manipulada ou distorcida de uma realidade, que de outro modo, deve se apresentar em sua verdade, independente das condições históricas de sua produção e reprodução social e da posição ou dos interesses de classe dos sujeitos sociais. O que nela se expressa, antes de tudo, são as condições práticas de socialização, subjetivação e adaptação dos indivíduos à ordem de dominação social em que estão de fato inseridos. O que nela sempre está em jogo é a naturalização, a normalização e a legitimação das práticas e relações sociais que organizam uma determinada configuração histórica da produção e reprodução social da vida. Sua existência é sempre a expressão do modo com a dominação material e econômica de uma classe precisa poder se afirmar, permanentemente, como hegemonia ideológica sobre o processo de formação da consciência socialmente determinada e como hegemonia política sobre as instituições da 'sociedade civil' e do Estado (DANTAS, 2008, p. 94)
\end{abstract}

O capital, que está eternamente na busca da "fabricação ininterrupta de novas necessidades" - como forma de garantir a lógica da sua reprodução, precisa de aliados que possam afirmar e reafirmar a "pseudo necessidade de ampliar constantemente a esfera do que pode ser consumido" como a base necessária para que a acumulação indefinida do capital não seja interrompida. Os mecanismos de convencimento, presentes nas esferas midiáticas, realizam o seu trabalho permanente de convencer a sociedade do único interesse "universal" 
que une a classe trabalhadora e o capital, que tem o poder de conciliar antagonismos outros, que é a busca crescente do desenvolvimento da prosperidade.

Mídia e capital se misturam e se fundem, estando um a serviço do outro, de modo que nada e nem ninguém escapem da sociedade de consumo. O que evidencia a garra com que os tradicionais segmentos da mídia privada, cujo discurso foi analisado no âmbito da Conferência Nacional de Comunicação, lutam para preservar em suas mãos o poder sobre os meios de produção midiática, afastando eventuais possibilidades de fiscalização e controle.

\subsubsection{Os movimentos sociais na contemporaneidade}

Para a socióloga e doutora em Ciência Política, Maria da Glória Gohn - que se especializou nos estudos e pesquisas sobre os movimentos sociais -, há muitas lacunas que precisam ser preenchidas para que esses movimentos sejam mais bem compreendidos. De acordo com sua abordagem teórica, "um movimento social é sempre expressão de uma ação coletiva e decorre de uma luta sociopolítica, econômica ou cultural" (GOHN, 2012, p. 14). Para que certas ações sejam identificadas como movimentos sociais, Gohn enumera os seguintes elementos constituintes que, necessariamente, estão sempre presentes:

$\checkmark$ demandas que configuram sua identidade;

$\checkmark$ adversários e aliados;

$\checkmark$ bases, lideranças e articuladores;

$\checkmark$ redes de mobilização;

$\checkmark$ práticas comunicativas diversas;

$\checkmark$ projetos ou visões de mundo que dão suporte às suas demandas;

$\checkmark$ culturas próprias nas formas como sustentam e encaminham suas reivindicações.

Os movimentos sociais, geralmente, organizados a partir da sociedade civil, nascem da busca e da necessidade de garantia de direitos individuais ou coletivos. "Os movimentos têm nos direitos a fonte de inspiração para a construção de sua identidade" (GOHN, 2012, p. 14). Os direitos coletivos geralmente pertencem a algum tipo de grupo social e os individuais estão inseridos no rol dos direitos humanos fundamentais. Mas tanto um como o outro têm como referência o universal - o direito igual para todos - cujas demandas são referenciadas a partir da igualdade de condições entre aqueles que fazem parte do grupo.

A sociedade contemporânea brasileira, na avaliação da pesquisadora, oferece um cenário em que há condições de surgimento de movimentos sociais estruturados com 
autonomia para viabilizar a emancipação dos sujeitos que os compõem, mas são raros os que se organizam dessa forma. Alguns possuem certas condições de se colocarem como movimentos sociais propriamente ditos, outros, simplesmente, "tornam-se comunidades autorreferenciadas" (GOHN, 2012, p. 15).

Em estudos mais recentes, Gohn observa que várias lutas sociais - anti ou alter globalização- rompem fronteiras e rapidamente se internacionalizam. Os novos conflitos que surgem, quase sempre, são decorrentes de mudanças ou da ausência delas, ocorridas no final do século XX. As temáticas são as mais variadas e vão desde a biodiversidade, o biopoder, as demandas étnicas e os conflitos religiosos. Em muitos casos, surge um "sujeito coletivo que passa a dominar o cenário desses conflitos”. A percepção que Gohn adquiriu a partir de suas pesquisas é que:

No final do século XX e início deste milênio, o tema dos movimentos sociais retoma um lugar central no plano internacional como objeto de investigação por intermédio do movimento antiglobalização, de uma nova perspectiva: como movimento global que rompe as barreiras das nações e se torna não apenas internacional, mas transnacional. A ênfase está nas redes que constroem, e os fóruns que realizam são seus momentos principais de visibilidade (GOHN, 2012, p. 43).

Glória Gohn argumenta que os movimentos sociais neste início de século, especialmente no Brasil, diferem muito dos que ocorreram em décadas anteriores, não somente por causa da entrada em cena do aparato tecnológico consolidado pela internet, mas porque mudaram seu horizonte de atuação e perspectiva. “...Os movimentos anteriores lutavam para ter "direito a ter direitos", não estavam autocentrados, não miravam apenas a si próprios" (GOHN, 2012, p. 12). Atualmente, muitos dos que ela chamou de "novíssimos movimentos ou ações civis denominadas movimentos" mudaram o foco, não têm mais o universal como horizonte, mas sim o particular. Os interesses imediatos preocupam-se com o direito de sua categoria ou grupo social.

Embora em muitos casos o foco tenha se afunilado, Gohn reconhece que houve "uma ampliação desses sujeitos enquanto protagonistas de ações coletivas", além de ter ocorrido uma mudança na forma de atuação - agora em redes - e ampliação das fronteiras dos conflitos e tensões sociais, em virtude da nova geopolítica que se estabeleceu em função da globalização. As mudanças estão acontecendo não apenas no Brasil, é um fenômeno mundial. Segundo Gohn (2012) ressalta a pesquisadora, 
a difusão do uso das novas tecnologias e a expansão dos meios de comunicação, os conflitos étnicos provocados pelos processos imigratórios e pelos deslocamentos migratórios no interior das nações, as novas políticas sociais de caráter compensatório dos governos - central e local - as demandas multi e interculturais têm refletido na conjuntura sociopolítica em que atuam os movimentos sociais e em formas de associativismo ( $\mathrm{GOHN}$, 2012, p. 1).

Em seu mais recente trabalho, no qual Gohn desenvolve novas teorias sobre os movimentos sociais na contemporaneidade, ela busca a contribuição dos estudos do sociólogo francês Alain Touraine, para compreender o papel do sujeito coletivo e a questão da multiculturalidade, tomando como referência os movimentos sociais. Para Touraine, "a noção de sujeito coletivo tem a ver com a capacidade de interferir nos processos sociais" (TOURAINE apud GOHN, 2012, p. 113).

Segundo explica Gohn (2012, p. 112), “o sujeito é considerado uma categoria fundamental, que constitui e posiciona indivíduos na história dos processos sociais, culturais e políticos de uma sociedade". A ação desse sujeito, enquanto agente do seu tempo e da sua história, é reconhecida por outro sujeito e se constitui como sujeito coletivo no processo de interação com outros sujeitos. Aos poucos, em meio ao processo histórico e social de uma comunidade, de uma sociedade, ou de um país, "o sujeito passa a ser reconhecido objetivamente - e subjetivamente é reconhecido como membro de uma sociedade, de uma etnia, como parte de um gênero" (GOHN, 2012, p. 113).

O sociólogo francês Alain Touraine, de acordo com Glória Gohn, retoma a tese de que não há movimento social sem a presença contestatória do sujeito. Na medida em que esse sujeito é reconhecido por outro e passa a agir como sujeito coletivo, que, por sua vez, expressa demandas de diferentes naturezas, tem capacidade de interlocução com a sociedade tanto civil como política ou empresarial, e desenvolve uma identidade com o grupo do qual faz parte e com o qual compartilha valores e crenças.

No entendimento dessa nova teoria que tenta explicar os movimentos da atualidade, os movimentos sociais não mobilizam apenas pessoas e reivindicações, "mobilizam princípios e sentimentos" (TOURAINE apud GOHN, 2012, p. 107), como mostra o trecho:

Os novos movimentos sociais falam mais de uma autogestão que de um sentido de história e mais de democracia interna do que de tomada de poder... Os movimentos sociais são as forças centrais da sociedade por serem sua trama, o pulsar da sociedade, seu coração (TOURAINE apud GOHN, 2012, p. 101). 
As motivações que mobilizam hoje o sujeito coletivo são bem distintas daquelas que o mobilizaram no século passado, quando a lógica do conflito estava centrada nos interesses antagônicos entre a sociedade e o governo, na luta pelo poder. As transformações geradas pela globalização e pelo avanço da tecnologia mudaram o foco das mobilizações, pois "o processo de produção perdeu importância e o mundo do consumo foi transformado no grande espaço de socialização das relações sociais, assim como a comunicação" (TOURAINE apud GOHN, 2012, p. 109).

E para finalizar este tópico que discute os movimentos sociais, vale trazer uma interpretação feita, mais uma vez por Touraine, acerca do tema que guarda certo paralelismo com o tipo de movimento que é feito no Brasil pelas entidades sociais que defendem um marco regulatório democrático para a comunicação:

...a noção de movimento social só é útil se permite pôr em evidência a existência de um tipo muito específico de ação coletiva, aquela pela qual uma categoria social, sempre particular, põe em questão uma forma de dominação social, seja particular ou geral, e invoca contra ela valores, orientações gerais da sociedade que comparte com seus adversários para privá-la de tal modo de legitimidade... (TOURAINE apud GOHN, 2012, p.109).

\subsubsection{A sociedade civil como protagonista}

Com o amadurecimento dos movimentos sociais, é cada vez mais evidente o empoderamento das entidades da sociedade civil que tomam a frente dos movimentos e ações articuladas em defesa de causas diversas. Gohn (2008) destaca que "no Brasil atual, o protagonismo ampliou-se não somente entre vários setores da sociedade civil e invadiu a sociedade política, realizando parcerias com o Estado e desenvolvendo uma nova esfera pública".

Ainda segundo Gohn (2012), “a realidade se alterou, novíssimos sujeitos entraram em cena, novas formas de ação social coletiva emergiram, novas categorias de análises foram criadas, e as teorias, por sua vez, também se ampliaram”. Com o advento da globalização e o consequente questionamento do papel do Estado como agente regulador, "ocorreu um deslocamento de interesse para a sociedade civil e, nesta, os movimentos sociais são citados como uma das ações sociais por excelência" (GOHN, 2012, p. 10).

Para Gohn (2008), não se trata, naturalmente, de qualquer tipo de participação, "tratase de uma força específica que leva à mudança e à transformação social”. O que provocou a 
reação e a rearticulação de movimentos sociais mais combativos foi a própria ineficiência do Estado. De acordo com a autora, essa participação social é entendida como

um processo de vivência que imprime sentido e significado a um grupo ou movimento social, tornando-o protagonista de sua história, desenvolvendo uma consciência crítica desalienadora, agregando força sociopolítica a esse grupo ou ação coletiva, e gerando novos valores e uma cultura política nova (GOHN, 2008, p. 30).

No estudo de Gohn (2008), pelo menos 13 eixos temáticos são enumerados, em torno dos quais está se desenvolvendo algum tipo de movimento ou ação social, entre eles Gohn cita, em último lugar, os movimentos sociais no setor da Comunicação, a exemplo do Fórum Nacional pela Democratização da Comunicação (FNDC). Os mais comuns se relacionam à luta pela inclusão social, mais moradias nas cidades, melhorias nos campos da educação e da sociedade, bem como questões afetas aos direitos humanos, à situação nos presídios e das minorias, e à preservação e defesa das culturas locais.

Já para Castells (1999), que desenvolve a discussão acerca da organização da sociedade em face da supremacia da internet, o surgimento dos movimentos sociais, independentemente do sucesso alcançado, é uma marca indelével do nosso tempo. O sentido e a força desse tipo de organização ficam agregados na memória coletiva da sociedade, como mostra o seguinte texto:

\footnotetext{
Independentemente das conquistas mais evidentes dos movimentos sociais, sua própria existência já produziu algum significado não apenas para os atores sociais, mas para toda a comunidade. $\mathrm{E}$ isso vale não só para $\mathrm{o}$ período de duração do movimento, mas para a memória coletiva da comunidade... tal produção de significado é um elemento essencial das cidades, ao longo da História, pois o ambiente construído, bem como seu significado, são engendrados por um processo de conflito entre os interesses e valores de atores sociais antagônicos (CASTELLS, 1999, p. 80).
}

\subsubsection{A nova comunicação em rede e seu impacto nas práticas sociais}

Discutir aqui o que seja a internet e o seu papel na sociedade contemporânea, que passa por um processo de reorganização a partir das mudanças provocadas pela tecnologia, não é exatamente o objetivo deste trabalho. O que é fundamental discutir é como a internet colaborou para requalificar o debate entre a sociedade e o Estado, entre a sociedade e o segmento empresarial privado, e entre os membros dessa sociedade atravessada, irreversivelmente, pela forma de comunicação virtual possibilitada pela web. 
Neste trabalho - que discute o confronto de discursos em uma conferência de comunicação - é crucial analisar os diálogos, a guerra de posições, a eterna luta pelo poder e a democratização da mídia após o surgimento da internet. Situação muito diferente do que aconteceu em 1988, quando a sociedade civil estava aprendendo novamente a se reorganizar, depois de 21 anos de ditadura e ainda sem o suporte libertador da tecnologia. Atualmente, com o fortalecimento dos movimentos sociais e dentro da nova arquitetura da Informação e da Comunicação, a conversação mudou de patamar e mudou de forma, assumindo novos contornos. Essa nova comunicação trouxe o empoderamento do cidadão por meio da sua capacidade de também produzir informação e desencadear ações descentralizadas que geram não somente manifestações de massa, mas transformações sociais. "A internet não é simplesmente uma tecnologia é um meio de comunicação" (CASTELLS, 2003, p. 116).

A questão não se trata de acreditar se os movimentos sociais vão conseguir provocar na sociedade brasileira tal reação à concentração da mídia ou levar às ruas multidões em defesa do marco regulatório democrático. Não é isso, a bandeira da democratização dos meios não mobiliza a massa e não a sensibiliza. $O$ fato é que a tecnologia está fazendo pela comunicação o que o Congresso Nacional não fez, ao se omitir, durante quase 25 anos, diante da necessidade da regulação dos artigos do Cap. V da Constituição. Se houvesse uma regulação para ser cumprida, os oligopólios não seriam o que são hoje, a propriedade cruzada dos meios não seria tão intensa e os políticos não seriam detentores de tantas emissoras.

A internet está fazendo com que os eternos excluídos da grande mídia, da grande estrutura capitalista do entretenimento, encontrem mecanismos e criem suas próprias mídias. Suas produções culturais regionais ou independentes estão chegando onde as pessoas estão. $\mathrm{O}$ youtube, como plataforma aberta e livre, está aí e é facilmente acessado para o bem ou para o mal, ao alcance de todos que estão na rede, mas está fora do esquema capitalista e excludente da cultura e da informação da grande mídia, que exige protocolos e processos de seleção extremamente excludentes.

O que a internet está provocando nas relações sociais e em toda a sociedade é um processo em andamento cujos efeitos vão sendo percebidos e interpretados, concomitantemente, aos acontecimentos, como diz Castells (2003):

A internet é o tecido de nossas vidas. A tecnologia da informação é hoje o que a eletricidade foi na Era Industrial. A internet poderia ser comparada a uma rede elétrica, em razão da sua capacidade de distribuir a força da informação por todo o domínio da atividade humana... a internet passou a ser a base tecnológica para a forma organizacional da Era da Informação: a rede (CASTELLS, 2003, p. 7). 
Esse conceito de rede é central na reflexão de Castells (2003) sobre essa nova forma de organização da sociedade e, ao mesmo tempo, é de uma simplicidade que não exige nenhum conhecimento intelectual para alcançá-lo. Imagine uma rede, uma rede de pesca, um conjunto de nós que estão interconectados, um ligado ao outro, e todos ligados numa mesma teia. "A formação de redes é uma prática humana muito antiga, mas as redes ganharam vida em nosso tempo transformando-se em redes de informação energizadas pela internet" (CASTELLS, 2003, p. 7).

Essa formação em rede permite uma flexibilidade e adaptabilidade que faz com que a internet consolide sua natureza revolucionária e autônoma, de difícil controle e de fácil acesso. Segundo Castells,

a internet é um meio de comunicação que permite, pela primeira vez, a comunicação de muitos com muitos, num momento escolhido, em escala global. Assim como a difusão da máquina impressora no Ocidente criou o que McLuhan chamou de a "galáxia de Gutemberg" ingressamos agora num novo mundo de comunicação: a galáxia da internet (CASTELLS, 2003, p. $8)$.

Castells (2003) lembra, entretanto, que não é só a tecnologia que está mudando a sociedade, a sociedade também está mudando a tecnologia na sua incessante interação, como mostra o seguinte trecho:

É que as pessoas, as instituições, as companhias e a sociedade em geral transformam a tecnologia, qualquer tecnologia, apropriando-a, modificandoa, experimentando-a. Essa é a lição fundamental que a história social da tecnologia ensina, e isso é ainda mais verdadeiro no caso da internet, uma tecnologia da comunicação (CASTELLS, 2003, p. 10).

Respeitados os protocolos técnicos de existência, a internet é uma tecnologia “particularmente maleável” (CASTELLS, 2003, p. 10), sendo passível de ser profundamente modificada pela sua prática social e podendo, portanto, ser uma arma facilmente manipulável para o bem ou para o mal.

Para Castells,

...nossa prática é baseada na Comunicação, nossas vidas são profundamente afetadas por essa nova tecnologia da Comunicação... que ao usá-la de muitas maneiras, nós transformamos a própria internet. Um novo padrão sociotecnológico emerge dessa interação (CASTELLS, 2003, p. 10). 
Entretanto, Castells (2003) faz questão de enfatizar que "a tecnologia não determina a sociedade" e nem é determinada por ela. Todavia é inegável uma relação dialética entre uma e outra, uma vez que hoje não é possível pensar a sociedade contemporânea sem levar em conta a tecnologia que a suporta e a comunicação que a atravessa cotidianamente. Está tudo interligado e misturado, o que pode mudar é a forma como uma ou outra sociedade se apropria da tecnologia, que está diretamente ligada ao papel do Estado no processo:

o papel do Estado, seja interrompendo (no exemplo clássico de Cuba e da China), seja promovendo, seja liderando a inovação tecnológica, é um fator decisivo no processo geral, à medida que expressa e organiza as forças sociais dominantes em um espaço e em uma época determinados (CASTELLS, 2003, p. 132).

No caso do Brasil, que ainda espera que o Estado crie condições para uma regulamentação democrática dos meios, numa relação de dependência com um Poder Legislativo que não se sensibiliza com a premência dessa demanda, o mais normal a ser esperado é que a tecnologia atropele a letargia legislativa e que o Marco Civil da Internet ${ }^{104}$ promova os avanços que a sociedade espera.

Atualmente, mais do que em outros momentos de crise por que passa a sociedade contemporânea, a internet se conforma como uma arena livre de debates e de construção de consensos e identificação de interesses. "O ciberespaço tornou-se uma ágora eletrônica global em que a diversidade da divergência humana explode numa cacofonia de sotaques" (CASTELLS, 2003, p. 115) ao mesmo tempo em que se transforma num espaço virtual de encontros e diálogos.

Alcunhar a internet de a nova "ágora virtual" 105 está perto de ser um assunto pacificado entre os especialistas e estudiosos do tema. É inevitável que a discussão recaia sobre a ressignificação do conceito de esfera pública deste trabalho. Herdado de Habermas, o modelo proposto de esfera pública burguesa, por mais polêmicas que tenha suscitado, foi um divisor de águas no debate sobre o assunto por aqueles que se esforçaram em desintegrar o conceito ou pelo próprio Habermas, que reconheceu suas fragilidades, e pelos defensores da validade do conceito. $\mathrm{O}$ fato é que a partir dessa conceituação muita coisa foi feita, refeita,

\footnotetext{
${ }^{104}$ O Marco Civil da Internet foi aprovado e sancionado pela presidente Dilma em 24/4/2014. Ele regula o uso da internet e estabelece princípios, garantias e direitos para os usuários da rede.
}

\footnotetext{
${ }^{105}$ Ágora era a praça principal na constituição da pólis, a cidade grega da Antiguidade clássica. Normalmente, era um espaço livre de edificações, onde os cidadãos costumavam ir, configuradas pela presença de mercados e feiras em seus limites, assim como por edifícios públicos.
} 
revisada, mas nunca desprezada. Nem que seja simplesmente para ser contra, o conceito habermasiano foi muito importante para aquele momento e continua sendo até hoje.

Tendo por base o que foi construído para dar densidade ao conceito de Habermas, numa época em que sequer se imaginavam as tessituras desencadeadas pela rede mundial de computadores, a certeza é que os fundamentos sociológicos e filosóficos que estruturaram a esfera pública de então podem facilmente ser adaptados à nova realidade. $\mathrm{O}$ que na época pode ter sido considerado como "esferas públicas coexistentes" (HABERMAS, 2003, p. 54), que estariam tangenciando a esfera pública burguesa, hoje estariam facilmente contempladas na nova esfera virtual estabelecida pela internet, com todos os seus tentáculos e intersecções.

O advogado e doutor em Sociologia, Lizt Vieira, traz importante contribuição nessa discussão sobre o início da globalização, atualizando o conceito habermasiano de esfera pública, conforme o trecho a seguir:

Com o ingresso de novos grupos na esfera pública e a expansão dos direitos de cidadania e modernidade, não é mais possível imaginar um espaço público homogêneo e politicamente igualitário. O modelo habermasiano amplia o âmbito da atividade política, fertilizando-a com os influxos comunicativos provenientes da sociedade civil (VIEIRA, 2001, p. 65).

A concepção de esfera pública, elaborada por Habermas (2003), é ressignificada na sociedade contemporânea e contempla, de certa forma, os movimentos organizados ou não, que emergem da sociedade civil. "O conceito de esfera pública ocupa posição central na teoria habermasiana como arena de formação da vontade coletiva. É o espaço do debate público, do embate dos diversos atores da sociedade" (VIEIRA, 2001, p. 63). Em quais plataformas esses embates ocorrem é o elemento novo incorporado pelos movimentos sociais organizados. Não há como falar hoje em reação e disputa, seja em face das decisões do Estado ou do gigantismo de setores hegemônicos da sociedade civil empresarial, sem incluir os aparatos tecnológicos oferecidos pela internet.

Reiterando Habermas (2003), mas deslocando-o da esfera pública da sua territorialidade tradicional, a esfera pública continua sendo

o local de disputa entre os princípios divergentes de organização da sociabilidade. Os movimentos sociais constituem atores que regem a reificação e a burocratização, propondo a defesa das formas de solidariedade ameaçadas pela racionalização sistêmica. Eles disputam com o Estado e com o mercado a preservação de um espaço autônomo e democrático de organização, reprodução da cultura e formação da identidade e solidariedade (VIEIRA, 2001, p. 63). 
Essas condições, pois, estão possibilitadas pela internet. Se no século XVIII a esfera possível, dadas às condições materiais, surgiu pelo discurso que emergiu dos cafés, das praças ou de pontos de encontro informais em mercados de secos e molhados, no século XXI "a revolução da tecnologia da informação forneceu a base indispensável para a criação de uma rede global de interação" (CASTELLS, 1999, p. 119). Essa rede entrelaçada de fios invisíveis, que transformou o processamento da informação, "age sobre todos os domínios da atividade humana e possibilita o estabelecimento de conexões infinitas entre diferentes campos" (CASTELLS, 1999, p. 120). Não há porque temer a nomenclatura "esfera pública virtual".

Se na concepção pretérita de "esfera pública burguesa" havia a preocupação em criar algum tipo de interlocução com o poder da época, ou seja, a ideia não era apenas discutir, mas ser ouvido pelas instâncias superiores, a de agora perpassa por esse desejo e vai além. Mais do que querer ser ouvido, os membros, nômades e autônomos, e muitas vezes anônimos, da nova esfera buscam falar entre si, fortalecer o diálogo horizontal e buscar o diálogo entre seus pares.

O que entrelaça essa comunicação horizontal, atualmente, é a unidade em torno de interesses comuns, independentemente da base territorial em que se encontra o internauta. Se o indivíduo está ancorado na rede motivado pela defesa e proteção do meio ambiente, certamente não será uma voz isolada, pois a articulação entre o seu desejo e o do outro será quase que imediata. Se este cidadão defende o controle na emissão dos gases de efeito estufa ouse luta contra as minas de carvão na China, ele encontra uma identidade; esse mesmo ator social se agrupa em torno do mesmo sentido e faz dele sua bandeira de luta contemporânea.

Fica cada dia mais claro o empoderamento produzido pela internet nos novos atores sociais que já garantiram seu lugar na grande esfera. Para o professor e estudioso da ciência da informação, Jambeiro (2007), mais e mais camadas sociais estão tendo acesso à tecnologia e conseguindo viver experiências políticas e sociais nos mesmos espaços que antes eram restritos à elite política e econômica. Tudo isso tem a ver com mais cidadania, na medida em que novos espaços públicos estendidos são acessíveis, como mostra o trecho a seguir:

As possibilidades de os diversos grupos da sociedade, usando os serviços oferecidos pela tecnologia comunicarem-se intra e entre si, e assim tornarem-se cônscios de suas identidades e de seus interesses comuns, facilitando dessa maneira sua organização em função de suas necessidades, inclusive de representação política, social e cultural, tendem a se consolidar naturalmente (JAMBEIRO, 2007, p. 118). 
Na medida em que mais pessoas, novos grupos sociais e novas comunidades passam a não apenas ter acesso aos meios, mas a ficarem expostos aos serviços oferecidos pela web, sentem-se pertencentes a uma mesma sociedade e a uma mesma identidade, e partilham do mesmo anseio de democratização e participação nos destinos do país. Com o uso do que a internet oferece, grupos que antes não tinham voz passam "a ter possibilidades de falar diretamente para a sociedade como um todo, usando seus próprios valores" (JAMBEIRO, 2007, p. 118). Em médio e longo prazo, essa nova configuração acabará por implicar uma significativa alteração nas bases conceituais em que funciona a estrutura midiática do País, com consequências imprevisíveis, mas, certamente, mais plurais.

A antropóloga Ruth Cardoso, em prefácio à sétima edição da obra de Manuel Castells, “O Poder da Identidade", sintetiza o espírito dessa tendência e reconhece que, apesar de já estarmos vivendo a Era da Revolução Tecnológica, há pelo menos 30 anos, é impossível prever o que ainda está por vir. A única certeza é que a humanidade ainda engatinha nas possibilidades desse novo paradigma estruturante da sociedade contemporânea. Se a globalização não conseguiu sufocar ou "apagar a presença de novos atores políticos" isso se deve ao surgimento avassalador da internet, pois, de acordo com Cardoso,

a internet criou para eles novos espaços pelos quais se inicia um processo histórico que não tem direção prevista. A criatividade, a negociação e capacidade de mobilização serão os mais importantes instrumentos para conquistar um lugar na sociedade em rede (CARDOSO in CASTELLS, 1999).

Fazendo um contraponto com a globalização, que impôs padrões econômicos autoritários, a internet surgiu como um espaço de resistência, pois permite à sociedade os seus mais diversos usos e aplicações. Se a revolução tecnológica foi apropriada na reestruturação do capitalismo globalizado, também foi incorporada como aliada dos novos atores da sociedade civil, que a conquistaram como um espaço próprio e autônomo. É como se o capitalismo, que, certamente, criou as condições materiais para o arrojado desenvolvimento tecnológico das últimas décadas, tivesse perdido o controle sobre sua mais nobre e audaciosa criatura. Nem mesmo o poder econômico foi capaz de manter a tutela sobre a internet, e ela não pode ficar enclausurada e acessível só para aqueles que detêm o poder econômico. Os próximos anos ainda vão trazer grandes mudanças para a sociedade e para a forma de como as pessoas vão se relacionar, a partir das possibilidades trazidas pela internet. Não seria exagerado dizer que ainda não é possível prever até onde a tecnologia irá levar a humanidade. 
Praticamente toda a humanidade ocidental está passando a se organizar em função do que a tecnologia está trazendo. O papel está sendo abolido como fonte primeira de registro e confiabilidade e assinaturas eletrônicas estão sendo reconhecidas como legítimas. Em todas as instâncias da vida a tecnologia está provocando mudanças irreversíveis e deixando seus rastros. E não há outro segmento que esteja sendo mais frontalmente atingido do que a comunicação entre as pessoas ou entre o Estado e seus cidadãos.

A internet gerou, pois, o que Castells chamou de "sociedade em rede", fruto de uma comunicação que passou a se organizar a partir dessa nova plataforma tecnológica, que possibilitou um sistema de redes horizontais de comunicação sem fio. Se em Habermas esse conceito foi subjetivo, porém oriundo da materialidade das conversas face a face, na contemporaneidade o conceito passa a ser, literalmente, virtual, uma vez que é a sua invisibilidade que o torna real.

\subsubsection{A sociedade em rede e os nós dos nós}

É inegável que o cenário, no campo dos embates simbólicos, tenha ganhado novas tessituras. Terrenos até então conhecidos e duros, onde o poder constituído se locomovia com segurança, passam a ser movediços e capilarizados. Não é preciso ter autorização desse poder para se adentrar na arena, basta que se tenha a representação que o tema exige, conforme afirma Velloso:

O cenário virtual, ou o ciberespaço, passa a se constituir em importante território da esfera social, a ágora eletrônica virtual contemporânea, que possibilita aos fatos da vida privada, tratar fatos e fenômenos da esfera pública e, sobretudo redimensionar a esfera social. Por seu descentramento e atopia (...) enseja diluir as concentrações de poder e ampliar as participação dos atores sociais e a projeção de diversos segmentos (VELLOSO, 2008, p. 108). ${ }^{106}$

A nova esfera pública, ressignificada pela territorialidade virtual da internet, possibilita representações não mais materiais, de modo que as dimensões simbólicas se sobreponham a estas e, deliberadamente, atraiam novos atores e novas conexões venham à tona muito maiores e mais amplas. Todas essas interlocuções, por consequência, dão força e visibilidade a movimentos sociais que carecem de um canal de voz, ou eco, que reverbere fora

\footnotetext{
${ }^{106}$ Velloso, Ricardo Viana. Ci. Inf., Brasília, v. 37, no 2, p. 103-109, maio/ago. 2008.
} 
do campo virtual, e chegue até o arcaico e conservador poder das mídias tradicionais, como se deu com o movimento pela democratização dos meios de comunicação.

Todavia, reconhece Castells (1999, p. 500), “ainda não está claro o grau de sociabilidade que ocorre nessas redes eletrônicas, e quais as consequências culturais dessa nova forma de sociabilidade", o que está claro é que a internet, com todas as suas decorrências, para o bem ou para o mal, é irreversível e o mundo contemporâneo terá que lidar com ela. O que importa agora, depois de cerca de 30 anos da existência consistente da internet na vida das pessoas, no exterior, e quase 20 anos, mais ou menos, no Brasil, é que ela, de fato, trouxe um novo significado social para o tempo e o espaço, que são as maiores dimensões materiais da vida humana. Surgiu uma sociedade em rede e sua construção sobre fluxos. Ainda conforme Castells,

nossa sociedade está construída em torno de fluxos: fluxos de capital, fluxos de informação, fluxos de tecnologia, fluxos de organização, fluxos de imagens, sons e símbolos. Fluxos não representam apenas um elemento da organização social: são a expressão dos processos que dominam nossa vida econômica, política e simbólica (CASTELLS, 1999, p. 501).

É preciso lembrar que a organização construída a partir dos fluxos, explica, mas não representa apenas um elemento dessa rede, pois ressignifica os processos sociais que dominam a vida econômica, política e simbólica das pessoas. Para clarificar um pouco mais o conceito, vale a pena transcrever o que Castells (1999) entende por fluxos: "são as sequências intencionais, repetitivas e programáveis de intercâmbio e interação entre posições fisicamente desarticuladas, mantidas por atores sociais nas estruturas econômica, política e simbólica da sociedade" (CASTELLS, 1999, p. 501).

Também estão presentes nessas práticas sociais as que se caracterizam pela dominação, estando estas, portanto, incrustadas nas estruturas sociais dominantes, que não deixam de existir nessa nova concepção, apenas assumem outra roupagem. A combinação de três suportes materiais, explica Castells (1999), oferece a melhor compreensão para o conceito do espaço de fluxos e, de certa forma, define em que posição se coloca as forças de poder e de dominação. Esses três suportes ou camadas, como define o pesquisador, obedecem a uma necessária hierarquia, sendo a primeira a dos circuitos de impulsos eletrônicos, sinteticamente, uma base física da Tecnologia da Informação. Em seguida, identificamos a camada que se constitui dos nós criados dentro das redes, pontos de concentração de centros 
de importantes funções estratégicas. E, por fim, a terceira camada, que se refere "à organização espacial das elites gerenciais dominantes" (CASTELLS, 1999, p. 504).

Assim como na visão tradicional do conceito de sociedade, em que a elite econômica e tecnocrática ocupa uma posição de liderança e poder, representada por atores sociais, na nova organização espacial da sociedade essa dominação é também implementada por atores sociais. Só que nessa nova ordem, a elite dominante "anda de mãos dadas com sua capacidade de desorganizar os grupos da sociedade que, embora constituam maioria numérica, veem seus interesses apenas parcialmente representados". Ou seja, o poder se articula para desorganizar os movimentos sociais que passam a se constituir dentro da nova lógica da sociedade em rede.

Ainda de acordo com Castells (1999, p. 504), "é que a teoria do espaço de fluxos parte da suposição implícita de que as sociedades são organizadas de maneira assimétrica em torno de interesses dominantes específicos a cada estrutura social". Isso não deixa de ser a representação virtual da velha e discutida "luta de classes", só que dessa vez estabelecida em bases tecnológicas e com um elemento de força inédito. Embora seja irreversível a organização social em fluxos, “as próprias elites não desejam ou não podem transformar-se em fluxos, caso queiram preservar sua coesão social, desenvolver seu conjunto de regras e códigos culturais, por intermédio dos quais conseguem entender-se e dominar os outros, estabelecendo fronteiras 'internas' e 'externas' de sua comunidade cultural/política" (CASTELLS, 1999, p. 505). É que quanto mais coesa mais inacessível ela se torna e evita a "penetração excessiva" de novos representantes no mundo das decisões.

Esse elemento de força também pode ser chamado de elemento de resistência diante da lógica de dominação no espaço de fluxos. A capilaridade e o diálogo horizontal permitidos pela internet subvertem a tônica de dominação das elites, questionam e, ao mesmo tempo, rejeitam os códigos culturais embutidos na estrutura social estabelecida, que traz em si os elementos de dominação, e isso é dialético.

Castells (1999) insiste na teoria de que o surgimento da internet provocou uma nova lógica fundamental para os processos e formas sobre as quais a sociedade passou a se organizar, sem esquecer, é claro, que o papel do Estado está presente nessa relação entre tecnologia e sociedade. Em países como o Brasil, o Estado não age para interromper ou impedir a inovação tecnológica, como ocorre na China. De certa forma, o Estado chinês também não impede o desenvolvimento tecnológico, mas impede que a sociedade se aproprie do caráter libertário trazido pela internet. No Brasil, o Estado se omite na medida em que não age no sentido de regular os meios eletrônicos e garantir a neutralidade da rede. De qualquer forma, o Estado está presente e isso traz consequências. 
Segundo Castells (1999), o fundamental é perceber que, reconhecendo ou não, está surgindo um novo paradigma nas relações sociais, em função do novo paradigma tecnológico baseado na Tecnologia da Informação. "A tecnologia e as relações técnicas de produção difundem-se por todo o conjunto de relações e estruturas sociais, penetrando no poder e na experiência e modificando-os" (CASTELLS, 1999, p. 54).

O espaço e o tempo estão normalmente interligados na compreensão da natureza ou da sociedade, o que muda, a partir do novo paradigma tecnológico, é que não é mais o tempo o fator determinante, "é o espaço que organiza o tempo na sociedade em rede" (CASTELLS, 1999, p. 505). A tecnologia está gerando novas formas e processos espaciais, que passam a se constituir a partir dessa nova lógica, ainda a ser compreendida na sua complexidade.

De acordo com Castells (1999), não se trata mais de dizer ou de considerar o espaço como um reflexo da sociedade. "O espaço é a expressão da sociedade, não é uma fotocópia da sociedade, é a sociedade" (CASTELLS, 1999, p. 500). Para explicar melhor essa definição, o pesquisador traça um paralelo com o estudo da Física. Enquanto nesta o espaço não pode ser definido fora da matéria, em teoria social o espaço não pode ser definido sem referências às práticas sociais.

Essas práticas sociais, por sua vez, passam a se dar em função da especificidade histórica da nova sociedade informacional. O espaço, portanto, é o suporte material das práticas sociais de tempo compartilhado, lembrando que estamos tratando aqui do "sentido simbólico". Em seguida, Castells (1999) acrescenta a noção de contiguidade e simultaneidade, lembrando que uma se dissocia da outra em função do que possibilitou a Nova Era da Informação: o distanciamento físico e a proximidade virtual.

A metáfora da rede entrelaçada de fios costurados em nós dá a exata dimensão do que representa para Castells a nova sociedade ressignificada pela revolução da tecnologia. Segundo esse autor, "rede é um conjunto de nós interconectados, sendo que o nó é um ponto qual uma curva se entrecorta" (CASTELLS, 1999, p. 506). A força desse nó ou o que ele representa depende dos fios que foram atados que, por sua vez, também representam redes concretas estabelecidas no mundo das coisas e das pessoas.

Para Castells (1999), essa nova estrutura social, que ainda está em formação no mundo pós-web, terá que ser mais bem compreendida a partir da construção de novas "categorias intelectuais" que possam dar conta de explicar esse novo fenômeno. As antigas foram constituídas em circunstâncias tão diferentes que não servem mais para explicar o novo, conforme mostra no seguinte trecho: 
A passagem dos meios de comunicação de massa tradicionais para um sistema de redes horizontais de comunicação organizadas em torno da internet e da comunicação sem fio introduziu uma multiplicidade de padrões de comunicação na base de uma transformação cultural fundamental, à medida que a virtualidade se torna uma dimensão essencial da nossa realidade (CASTELLS, 1999, II).

\subsubsection{O poder na rede e a rede do poder}

A nova configuração da sociedade em rede não deslocou de lugar apenas as pessoas, as comunidades e a sociedade contemporânea como um todo, modificou também o centro do poder. Não provocou, naturalmente, uma mudança dos donos do poder, não saiu das elites dominantes e passou para os dominados, mas sofreu modificações com a nova dimensão de comunicação trazida pela tecnologia. A forma e a maneira como o poder é exercido na sociedade em rede está se modificando em relação à estrutura tradicional da velha sociedade.

Apesar de Castells (2009) reconhecer que nem todas as pessoas estão conectadas pela web (vide a exclusão digital) e, portanto, não estarem incluídas nesse novo conceito de sociedade em rede, ele argumenta que ainda assim "todo o mundo se vê afetado pelos processos que têm lugar nas redes globais dessa estrutura social" (CASTELLS, 2009, p. $51)^{107}$. Até porque o poder instalado nas elites dominantes, ainda que nos países periféricos e do Terceiro Mundo, é afetado pelo que a tecnologia está fazendo em outras redes de poder.

Castells (2009) argumenta que "o poder não é um atributo, ele é resultante de uma relação de dominação de um sobre o outro" (Idem, p. 34) ${ }^{108}$. E é essa relação que se modificou, assumindo novas nuances com a globalização, "que redefiniu os limites territoriais do exercício do poder" (Idem, p. 42) que foram ressignificados a partir das condicionantes possibilitadas pela internet, que, naturalmente, expandiu e rompeu fronteiras, como mostra o seguinte trecho:

A globalização, quando se leva a uma conclusão lógica, significa que as Ciências Sociais devem fundar-se como uma ciência baseada na realidade do transnacional, e isso desde o ponto de vista conceitual, teórico, metodológico e organizacional. Aqui se inclui o fato de que é necessário liberar os conceitos básicos da 'sociedade moderna' - casa, família, classe, democracia, dominação, estado, economia, esfera pública, política etc. - das fixações do nacionalismo metodológico e redefini-los e reconceitualizá-los

\footnotetext{
${ }^{107}$ Tradução livre do espanhol: Pero todo el mundo se ve afectado por los processos que tienen lugar em las redes globales de esta estructura social.

${ }^{108}$ Tradução livre do espanhol: La capacidad relacional significa que el poder no es um atributo sino uma relación.
} 
no contexto do cosmopolitismo metodológico (BECK apud CASTELLS, 2009, p. 42). ${ }^{109}$

A globalização tornou mais sofisticada e complexa a forma de relação entre dominantes e dominados que, segundo Castells (2009), é sempre exercida de forma assimétrica entre os atores sociais. Aquele que exerce o poder influi na decisão dos outros, de modo que a sua vontade prevaleça e isso se dá não apenas entre as pessoas, entre patrões e empregados, mas entre o Estado e a sociedade, por meio dos seus agentes e aparelhos. Castells afirma ainda que o poder é exercido mediante a coação ou a possibilidade de exercêla, e ainda mediante a construção de significados, a partir dos discursos dos atores sociais que guiam as ações de quem detém o poder (CASTELLS, 2009). Normalmente, essas relações são marcadas por assimetria, uma vez que há sempre maior grau de influência de um sobre o outro. Castells destaca que "em qualquer relação de poder há certo grau de cumprimento e aceitação daqueles que estão sujeitos ao poder" (Idem, p. 34) ${ }^{110}$. Castells faz referência a Gramsci (1975) em relação ao que o pensador italiano chamou de "consentimento dos de baixo".

O poder e a dominação quando não são exercidos pela violência física, mas por meio dos aparatos que naturalizam a coerção, tendem a ser mais duradouros e mais eficientes, no sentido de adiar qualquer reação ou resistência daqueles que são dominados, asujeitados aos que detêm o poder. Segundo Castells (2009, p. 35),

quanto maior é o papel deconstrução de significados em nome de interesses e valores específicos de determinado grupo, menor é a necessidade de se recorrer à violência (legítima ou não) para que se exerça o poder.

Mesmo na chamada velha sociedade, antes da internet, a legitimação do poder se dava com maior eficiência "a partir do consentimento obtido pela construção de significados compartilhados" (CASTELLS, 2009, p. 36). E essa construção se dá tanto pela comunicação como pelos aparatos do Estado como instituições políticas, escolas e igrejas. Numa

\footnotetext{
${ }^{109}$ Tradução livre do espanhol: La globalización, cuando se lleva a suconclusión lógica, significa que las ciências sociales debem refundar-se como una ciência basada em larealidad de lo transnacional, y ello desde El punto de vista conceptual, teórico, metodológico y organizativo. Aquí se incluye El hecho de que es necessário liberar los conceptos básicos de la 'sociedad moderna' - casa, familia, clase, democracia, dominación, estado, economía, esfera pública, política etc. - de lasfijaciones del nacionalismo metodológico y redefinirlos y reconceptualizarlos em el contexto del cosmopolitismo metodológico. (BECK apud CASTELLS, 2009, p. 42).

${ }^{110}$ Tradução livre do espanhol: Encualquier relación de poder hay um cierto grado de cumplimiento y aceptación de los que están sujetos al poder (CASTELLS, 2009, p. 34).
} 
democracia representativa como a do Brasil, há um compartilhamento de toda a sociedade de que esse é o regime desejado e aprovado, a cada período eleitoral, pelas urnas.

O que é fundamental registrar é como o poder funciona na sociedade em rede, sendo essa uma das grandes contribuições de Castells ao debate sobre o impacto das novas tecnologias na organização da sociedade contemporânea, conforme o texto abaixo:

O desafio analítico, nessa nova estruturação geral do tempo e do espaço, na sociedade em rede, é compreender as relações de poder que são específicas em cada um dos níveis (local/global) e a forma como elas impactam as práticas sociais e seus resultados estruturados (CASTELLS, 2009, p. 39).

Castells (2009) insiste que as relações de poder que existem nas estruturas sociais concretas se modificaram depois da internet e da globalização, em função "das formações espaço-temporais que se situam em nível local e global, ao mesmo tempo, às mudanças dos limites da sociedade e ao marco de referência do poder que transcende o nível nacional" (Idem, p. 43). O que não quer dizer, enfatiza, “que o estado-nação desapareça” (Idem, p. 43), mas que os limites nacionais das relações de poder sejam somente uma das dimensões em que o poder e o contrapoder operam. Segundo explica o sociólogo, não há que se buscar os limites territoriais nessa nova realidade, pois "temos que identificar as redes de poder sócio espaciais (locais, nacionais e globais) "que em sua intersecção configuram as sociedades" (Idem, p. 43). Castells vai buscar na terminologia da socióloga Saskia Sassen ${ }^{111}$ a melhor definição para a questão: “as formas de assembleia, nem locais, nem globais, senão ambas de uma vez, definem o conjunto específico de relação de poder que proporcionam as bases dessa sociedade" (SASSEM apud CASTELLS, 2009, p. 43).

A estrutura dessa nova sociedade tem como infraestrutura sua organização em redes digitais, que podem ser locais ou globais, ao mesmo tempo, o que possibilita uma "capacidade para se autorreconfigurarem-se, de acordo com o ordenamento da comunicação que travam entre si” (CASTELLS, 2009, p. 51). O atual processo de globalização, explica esse autor, está ocorrendo desse modo "por causa da capacidade de conexão em rede global, que proporciona uma velocidade e uma comunicação tão complexas que o diferencia de qualquer outro que tenha ocorrido em épocas históricas” (Idem, 2009, p. 51).

\footnotetext{
${ }^{111}$ Saskia Sassen é uma socióloga holandesa, conhecida por suas análises nos fenômenos de globalização e de migração urbana, e por ter cunhado o termo cidade global.
} 


\subsubsection{Autocomunicação e resistência}

Da mesma forma como o poder assumiu novas configurações, na sociedade em rede, o mesmo se deu com o que se pode chamar de "contrapoder". Segundo Castells:

Se o poder é exercido programando-se e alternando-se redes, então o contrapoder, a tentativa deliberada de alterar as relações de poder, é desempenhado reprogramando-se as redes em torno de outros interesses e valores, e/ou rompendo as alternâncias predominantes, ao mesmo tempo que se alteram as redes de resistência e a mudança social (CASTELLS, 2013, p. 14).

Em outros países, onde a sociedade busca formas de resistir ao poder estatal constituído, a internet atuou como mola propulsora no sentido de desencadear reações e mudanças como as analisadas por Castells sem seu livro "Comunicación y Poder”, de 2009, cujas reflexões ajudam a entender a forma de atuação do poder, a partir do avanço da tecnologia, e também a forma de resistência a esse poder. Castells (2013, p. 178) avançou em sua análise a partir dos eventos desencadeados após a Primavera Árabe, em 2011, no seu livro "Redes de Indignação e Esperança - Movimentos sociais na era da internet". Nesse livro, ele conta que estava no Brasil proferindo uma palestra no Seminário Fronteiras do Pensamento, quando, em junho de 2013, as manifestações de rua se intensificaram e arrastaram multidões em busca de "direitos e cidadania".

A realidade assistida por todo o mundo no final da primeira década do século XXI, como a Primavera Árabe, a mudança de governo na Tunísia, a queda do presidente do Egito Hosni Mubarak, o movimento Occupy Wall Street, e até mesmo a primeira eleição de Barack Obama confirmam, 10 anos depois, as percepções de Castells registradas em 1999 no seu livro "A Sociedade da Informação", quando surgiu uma nova sociedade articulada sob os auspícios da Era da Informação.

Castells (2009, p. 444) afirma, depois de enumerar protestos de ativistas pelo mundo todo, desde abril de 2000, em Washington, passando por Barcelona, Joanesburgo, Durban e até mesmo pelos fóruns sociais que aconteceram no Brasil, que "estes acontecimentos globais são somente a ponta do iceberg do descontentamento social e da crítica cultural acerca das direções tomadas pelo mundo global emergente".

O que diferencia esses movimentos de resistência e o descontentamento dos que marcaram os anos que se seguiram ao maio de 1968, na França, é exatamente a plataforma por meio da qual estão acontecendo - uma nova base que permite a superação de fronteiras e o encontro de interesses e objetivos que transcendem as bases territoriais. Se a ganância do 
velho capitalismo é quase a mesma, os atores sobre os quais eles sempre impuseram suas regras são outros e estão dotados de novas ferramentas e de um empoderamento coletivo e individual, ao mesmo tempo, jamais visto. Segundo Castells (2009, p. 444), "milhares de lutas locais por diferentes temas se conectaram mediante a internet e se difundiram tanto nos meios de comunicação principais como nas redes alternativas que surgiam em todo o planeta", conforme afirma no seguinte trecho:

A cultura da sociedade em rede é uma cultura de protocolos de comunicação entre todas as culturas do mundo, desenvolvidas sobre a base de uma crença comum no poder das redes e da sinergia obtida ao dar e receber dos demais. O processo de construção material da cultura da sociedade em rede está em marcha. Mas não se trata, todavia, da difusão da mentalidade capitalista através do poder exercido pelas elites dominantes da sociedade industrial. Tampouco das propostas idealistas dos filósofos que sonham com um mundo de cidadãos abstratos e cosmopolitas. É um processo no qual os atores sociais conscientes de diferentes origens contribuem com outros seus recursos e suas crenças, esperando receber o mesmo em troca, e ainda compartilhar um mundo diverso que acabe com o medo ancestral dos outros (CASTELLS, 2009, p. 68). ${ }^{112}$

Castells (2009) está convencido de que a troca que hoje ocorre dentro da sociedade global, entre distintas culturas, não se dá tão somente em face do compartilhamento de valores comuns, mas do valor imperioso da Comunicação. Isso quer dizer que a nova cultura não está baseada no conteúdo, mas no processo, tal qual a cultura democrática constitucional se baseia no procedimento, não em programas concretos, ou seja:

A cultura global é uma cultura de comunicação pela comunicação. É uma rede aberta de significados culturais que podem não somente existir, senão também interagir e modificar-se mutuamente sobre a base desse intercâmbio (CASTELLS, 2009, p. 68). ${ }^{113}$

A partir do que aconteceu em muitos movimentos, como o que desencadeou as revoltas no mundo árabe, Castells desenvolveu um novo conceito de Comunicação, dentro do

\footnotetext{
${ }^{112}$ Tradução livre do espanhol: La cultura dela sociedade redes uma cultura de protocolos de comunicación entre todas las culturas del mundo, desarrolhada sobre la base de una creencia comúnen el poder de las redes y de la sinergia obtenida al dar y recibir de lós demás. El proceso de construcción está en marcha. Pero no se trata de La difusión de la mentalidade capitalista através del poder ejercido por las elites dominantes heredadas de la sociedade industrial. Tampoco de las propuestas idealistas de los filósofos que sueñan com un mundo de ciudadanos abstractos y cosmopolitas. E sel processo por El cual actores sociales conscientes de diferentes Orígenes aportan a otrossus recursos y suscreencias, esperando recibirlo mismo cambio y más aún: compartir um mundo diverso que acabe com El miedo ancestral a los otros (CASTELLS, 2009, p. 68).

${ }^{113}$ Tradução livre do espanhol: La cultural global es una cultura de La comunicación por La comunicación. Es una red abierta de significados culturales que pueden no sólo coexistir, sino también interactuar y modificarse mutuamente sobre la base de este intercambio (CASTELLS, 2009, p. 68).
} 
conceito de interação, via web, chamado por ele de "autocomunicação", que explica, de certa forma, "essa nova forma de comunicação interativa caracterizada pela capacidade de enviar mensagens de muitos a muitos, em tempo real, em um momento concreto" (CASTELLS, 2009, p. 88). Não é uma comunicação que saiu de um ou dois emissores para milhares de receptores, é uma comunicação que não partiu de um único ponto, mas de vários para outros. É uma comunicação que abre mão da mediação, sem intermediários ou fronteiras.

Para esse pensador da web, três formas de comunicação coexistem e se complementam: a comunicação interpessoal, a de massa e a de "autocomunicação" de massas. O que é historicamente novo, também, é que a articulação entre todas essas formas "ocorre em um hipertexto digital, interativo e complexo, que integra, mescla e recombina em sua diversidade o amplo leque de expressões culturais produzidas pela interação humana" (CASTELLS, 2009, p. 88).

E como resistir? A resistência passa a ser criada e efetivada no processo de comunicação e a relação com a internet sendo absolutamente dialética, pois é nela que o cidadão busca o seu "estar no mundo" e com a correspondência imediata, pois o mundo também está todo dentro dele. Os donos das redes empresariais de multimídias globais, de acordo com Castells (2009), são, com certeza, "os que ostentam o poder na sociedade em rede". São eles que produzem a metarrede (Idem, p. 546) da rede das comunicações, pois processam o que pensamos, sentimos, idealizamos e lutamos. Para exercer o domínio que precisam sobre os atores sociais que se "alimentam" dessas redes, os meios "transformam os seres humanos em audiências" (Idem, p. 541), vendendo produtos culturais e de consumo irresistíveis.

Por essa razão, acredita Castells (2009), a“autocomunicação” só tende a crescer nos novos tempos, pois "aumenta nossa capacidade, possibilita que possamos criar nossas próprias mensagens e, potencialmente, desafia o controle empresarial da comunicação e pode mudar as relações de poder na esfera da comunicação" (Idem, p. 542). Talvez seja aí que resida um pouco de esperança. Todavia, pondera Castells, está se falando aqui de um mundo ainda em construção e em permanente ebulição.

\subsection{As escolhas metodológicas}

Se a teoria é fundamental para que se possa compreender a realidade, a metodologia tem igual importância quando se buscar analisar e extrair resultados do material empírico em 
uma pesquisa de cunho acadêmico. Neste caso, foi necessário mesclar duas escolas de análise, a Análise de Conteúdo (AC) e a Análise de Discurso.

A Análise de Conteúdo ajudou a selecionar dentro do material bruto os temas e expressões que tinham pertinência com os objetivos de pesquisa. Em função da presença destes temas neste ou naquele produto analisado, o mesmo era separado e destinado a um agrupamento de sentidos, chamado aqui "categoria de análise". Estes temas recebem o nome de "unidades de análise", as unidades vão compor as categorias. Por exemplo, se em determinado parágrafo de uma matéria de jornal aparecessem palavras como "liberdade de expressão" ou "controle social da mídia", esta matéria seria escolhida para figurar a categoria que iria receber matérias ligadas a este tema. A unidade de sentido: "controle social da mídia" passa a integrar a categoria denominada "Liberdade e Controle".

Com o agrupamento de todos os temas relevantes nas cinco categorias estabelecidas (Liberdade e Controle, Marco Regulatório para a comunicação, Acesso universal aos meios e participação social, Pluralidade midiática e Mudanças Tecnológicas) é chegada a hora de entrar em cena os suportes analíticos da Análise de Discurso. Por exemplo, ao analista desta escola de análise, de nada adianta ele estar diante da palavra "liberdade de imprensa" sem que ele saiba quem é que está “carregando" esta palavra, ou seja, quem é o dono dela, ela foi dita por quem e em que contexto. Esta palavra nunca vai estar só, ela pertence a um discurso, e este discurso pertence a alguém, e este alguém tem o seu lugar de fala. E é por meio deste lugar, deste contexto histórico que o análise começa a ser operacionalizada. A partir desta etapa os discursos vão deixando de ser opacos ou indiferentes e vão ganhando significados, que por sua vez, são traduzidos em respostas que podem atender ou não aos objetivos da pesquisa. A análise de discurso tem a função de iluminar os discursos e fazer com que o corpus finalmente ganhe significado.

\subsubsection{A Formação Discursiva dentro da Análise de Discurso}

Para compreender o processo de produção dos sentidos e sua relação com a ideologia, que é estruturante em $\mathrm{AD}$, é preciso conhecer três outros conceitos fundamentais: enunciado, formação discursiva e estratégia discursiva. Neste trabalho foi utilizado o conceito de Foucault:

O enunciado, ao mesmo tempo em que surge em sua materialidade, aparece como um status. Ele entra em redes, se coloca em campos de utilização, se oferece a transferências e modificações possíveis, se 
integra em operações e em estratégias onde sua identidade se mantém ou se apaga. Assim o enunciado circula, serve, se esquiva, permite ou impede a realização de um desejo, é dócil ou rebelde a interesses, entra na ordem das contestações e das lutas, torna-se tema de apropriação ou de rivalidade (FOUCAULT, 1987, p. 121).

Dominique Maingueneau (2002, p. 56), que também ampara teoricamente esta pesquisa, por sua vez, simplifica essa definição e sintetiza: "o enunciado é a marca verbal do acontecimento, que é a enunciação". E acrescenta que o enunciado designa uma sequência verbal de sentido completo em determinado discurso. Na etapa operacional da pesquisa, foram selecionados e recortados os enunciados proferidos pelos representantes da mídia tradicional e dos movimentos sociais, no contexto específico da Confecom, inclusive nos dias que antecederam sua realização.

Foi de grande importância para a pesquisa as circunstâncias em que os discursos foram construídos e manifestados, por isso foi utilizado o conceito de formação discursiva (FD), explicitado por Foucault (1987) como "unidades de continuidades milenares", bem como o conceito de Eni Orlandi, que afirma que "a noção de formação discursiva nos permite compreender o processo de produção dos sentidos, sua relação com a ideologia e também dá ao analista a possibilidade de estabelecer regularidades no funcionamento do discurso". Para Orlandi,

a formação discursiva se define como aquilo que numa formação ideológica dada - ou seja, a partir de uma posição em uma conjuntura sócio-histórica dada - determina o que pode e deve ser dito... Aquilo que o sujeito diz se inscreve em uma formação discursiva, e não outra, para ter um sentido e não outro (ORLANDI, 2002, p. 43).

Começa a ficar claro, portanto, "que as palavras não têm sentido nelas mesmas, mas derivam seus sentidos das formações discursivas em que se inscrevem, que, por sua vez, representam no discurso as formações ideológicas" (ORLANDI, 2002, p. 43). O sentido que cada enunciado carrega é sempre determinado ideologicamente, trazendo em si o rastro da sua história e constituição. Por exemplo, uma mesma palavra - liberdade - assume um significado diferente dependendo do sujeito que a profere e da formação discursiva em que esse sujeito está inscrito. 


\subsubsection{A função da Análise de Conteúdo}

Os fragmentos de texto, selecionados entre os produtos dos jornais e dos sites, são sentenças, frases ou períodos que têm relação com aquilo que se pretende analisar. A escolha por unidades temáticas indica que o recorte de conteúdo foi feito por temas e não por palavras. "O recorte em temas é mais rico porque são fragmentos mais completos, que correspondem a uma ideia particular" (LAVILLE; DIONNE, 1999, p. 217). A partir desses temas, recolhidos dos textos, as categorias foram formadas.

Quando um tema é extraído traz consigo a referência ao seu enunciador, logo, estamos tratando aqui de "enunciados", um termo da $\mathrm{AD}$ que dialoga com a AC. Os temas escolhidos nesta pesquisa, doravante, serão chamados de "enunciados", conforme os conceitos da AD.

As categorias foram formadas a partir dos enunciados, de acordo com os procedimentos teóricos da AC. Cada um dos fragmentos, que passaram a constituir as categorias da análise, foi extraído das matérias dos jornais ou dos sites, portanto, "as categorias criadas dizem respeito ao caráter dominante das matérias analisadas" (SOUSA, 2004, p. 164). A primeira fase da categorização teve embasamento teórico nas contribuições de Christian Laville e Jean Dionne, como mencionado, bem como em Laurence Bardim.

O processo de separar os temas em categorias só pode ser realizado após um estudo minucioso do material coletado, pois a categorização leva em conta o que se define pela identidade e pela aproximação. "A categorização é uma operação de classificação dos elementos constitutivos de um conjunto, por diferenciação, e, seguidamente, por reagrupamentos segundo o gênero (analogia), com os critérios previamente definidos" (BARDIN, 1970, p.45). No caso desta pesquisa, foram 39 produtos (editoriais, artigos, matérias, notas e cartas de leitores) dos três grandes jornais analisados e 61 produtos (artigos, entrevistas e matérias) dos sites selecionados.

\subsubsection{A montagem das categorias}

Cada categoria foi criada a partir da coleta de fragmentos identificados e extraídos no interior do material empírico tanto de um lado como do outro.

A finalidade do recorte dos conteúdos é, evidentemente, agrupar os elementos em função da sua significação, desde que estes sejam portadores de sentido em relação ao material analisado e às intenções da pesquisa. Os elementos assim recortados vão 
constituir as unidades de análise, ditas também unidades de classificação ou de registro (LAVILLE; DIONNE, 1999, p. 216).

A Análise do Conteúdo sugere que o que mais enriquece o corpus, embora seja mais delicado, é o recorte do conteúdo em temas, isto é, os fragmentos, que correspondem cada um a uma ideia em particular. Pode ser uma ideia que "trate de um conceito como o de "liberdade política" ou "liberdade de expressão", ou que traduza uma relação entre tais conceitos". Neste estudo, optou-se pela coleta de temas, como será demonstrado, por entender que "a pesquisa dos temas pode melhor aproximar o pesquisador do sentido do conteúdo, pois ele se vê obrigado, mais do que com as palavras, que dependem da estrutural textual, a construir suas unidades de análise a partir da compreensão desse conteúdo" (LAVILLE; DIONNE, 1999, p. 217).

Depois de coletar os dados, foi preciso estudar as frases e as sentenças que compõem o estudo em questão, para em seguida "procurar-lhes o sentido, captar-lhes as intenções, comparar, avaliar, descartar o acessório, reconhecer o essencial e selecioná-lo em torno das ideias principais" (LAVILLE; DIONNE, 1999, p. 214). Além das palavras, esta pesquisa utilizou-se das orações e dos temas.

A matéria-prima do jornalismo impresso são as palavras e a forma como umas se encadeiam com as outras, na busca da construção do sentido. A Análise do Conteúdo se debruça sobre o texto escrito, com o objetivo de "desmontar a estrutura e os elementos do conteúdo em questão, para esclarecer suas diferentes categorias e extrair sua significação" (LAVILLE; DIONNE, 1999, p. 215). A partir da leitura cuidadosa das matérias selecionadas dos jornais e dos sites, e em face das hipóteses estabelecidas, a pesquisadora agrupou os elementos extraídos do texto, portadores de sentido em relação à intenção da pesquisa.

É preciso reforçar o conceito do que seja um enunciado, fundamental na estrutura deste trabalho. A busca de um sentido nos remete ao enunciado, por ser portador de sentido pleno e nos remeter a uma significação mais completa dentro do corpus analisado. Além disso, o enunciado nos ajuda a compreender o conteúdo, sem deixar de lado nuanças importantes que nos posicionam diante da ideologia impregnada em cada uma das falas decodificadas nesta análise.

O que foi percebido, logo de início, é que cada unidade de sentido selecionada no corpus desta pesquisa tinha significado próprio quando surgia na voz dos movimentos sociais, do mesmo modo que recebia um significado diferenciado quando incorporado no discurso da mídia tradicional. Ou seja, como estamos trabalhando com dois lados antípodas que disputam 
a primazia da verdade, o cuidado com o contexto foi ainda maior. Até por que não há que se falar em verdade única. Quando se trata de disputa de discursos, é um reducionismo retórico excessivo afirmar que dentro da Conferência foi travado "um duelo pela verdade", pois o contexto era polêmico e multifacetado e, em muitas situações, uma briga de percepções, com cada um vendo apenas a sua verdade.

Por exemplo, enquanto para os representantes das entidades sociais a liberdade de imprensa pode e deve ser garantida com a criação de órgãos e conselhos fiscalizadores, para os representantes da mídia tradicional "o controle social é um eufemismo para subordinar o livre fluxo de informação aos interesses dos grupos organizados..." ${ }^{114}$. Cada lado aborda o mesmo conceito, de acordo com seus interesses e ideais, não sendo possível, portanto, trabalhar apenas com palavras ou frases fora do contexto em que se encontram. Por isso, a pesquisa optou pelo recorte do conteúdo em temas que foram extraídos de contextos específicos, que, por sua vez, contribuíram para a compreensão do seu adequado significado. A partir desses temas foram construídas as categorias de significado, fundamentais para que a pesquisa pudesse apresentar respostas.

Temas como liberdade de expressão, ou regulação dos meios, que foram frequentes no corpus delimitado - e muitas vezes manifestados em contextos diversos e até opostos -, sugerem certa dificuldade no momento da análise. E exatamente por isso, a coleta de temas, e não apenas de palavras ajuda o pesquisador a encontrar o sentido procurado. $\mathrm{O}$ agrupamento por temas é uma alternativa metodológica que facilita a a compreensão do conteúdo pesquisado.

Não é por acaso que esta pesquisa optou pelo uso dos procedimentos metodológicos da Análise do Discurso, para interpretar os conteúdos com maior carga semântica.

Graças à evolução dos pressupostos acadêmicos, por tanto tempo amparados em abordagens de cunho positivista- que entendiam que o pesquisador era apenas e tão somente um observador do objeto analisado, que tinha que ficar alheio aos fenômenos e processos que estava a observar -, o olhar do pesquisador ganhou espaço como interpretante. Uma pesquisa desta natureza, que foi em busca de marcas ideológicas impregnadas nos discursos construídos e manifestos num processo específico, não poderia alcançar seus objetivos se ficasse presa a apenas uma abordagem metodológica.

As categorias foram formadas a partir da mecânica oferecida pela $\mathrm{AC}$ e a partir dos fundamentos da $\mathrm{AD}$, logo, as mesmas categorias atenderam aos pressupostos das duas escolas

\footnotetext{
${ }^{114}$ Confecom aprova propostas restritivas ao jornalismo. O Estado de S. Paulo, 17/12/2009, p. 4.
} 
de análise, uma complementando a outra. Enquanto a AC contribuiu para extrair da superfície dos textos os enunciados relevantes, a $\mathrm{AD}$ deu o tratamento adequado para que os enunciados revelassem os sentidos e as relações existentes. As mesmas categorias foram trabalhadas pelas duas análises.

\subsubsection{O Sentido manifesto}

O sentido manifesto emergiu de cada um dos enunciados que foram proferidos pelos porta-vozes dos movimentos sociais, bem como dos que emergiram dos empresários. A maioria de cada um indicava direção e compreensão opostas, como será demonstrado adiante.

As categorias podem ser criadas antes da análise mais profunda no corpus, considerado "modelo fechado", em que "as categorias são decididas a priori com base em pressupostos teóricos" (LAVILLE; DIONNE, 1999, p. 219). Essas categorias vão tomando forma no curso da análise, como "modelo aberto", ou são montadas no início do processo, permitindo ao pesquisador modificá-las em função da análise. Esse é o "modelo misto", adotado neste trabalho. Como era previsto que os embates se dariam em torno de alguns conceitos-chave, como liberdade de imprensa, controle social e regulação dos meios, estes ganharam status de categorias logo no início das leituras.

O processo de criação das categorias de análise é, muitas vezes, um ir e vir na teoria e no material bruto, do qual se origina o corpus. É preciso fazer uma investigação exaustiva para que indícios importantes não fiquem excluídos e tomar cuidado para evitar superposição de dados.

A pesquisa optou por alargar sua percepção da unidade de sentido e passou a trabalhar com temas e não apenas com palavras ou frases. “...Se o pesquisador escolheu temas, se quer dar conta da importância de cada um, é preciso ir além da frequência de sua ocorrência, para dar uma medida mais precisa de seu lugar no conjunto do conteúdo". Foi nesse sentido que a pesquisa caminhou. A partir da frequência dos temas e da eventual ambiguidade, foi necessária uma abordagem mais qualitativa, em busca mais do sentido do que da forma.

O pesquisador decide prender-se às nuanças de sentido que existem entre as unidades, aos elos lógicos entre essas unidades ou entre essas categorias que as reúnem, visto que a significação de um conteúdo reside largamente na especificidade de cada um de seus elementos e na das relações entre eles, especificidade que escapa amiúde ao domínio do mensurável. (LAVILLE; DIONNE, 1999, p. 227). 
O objetivo é que na construção das categorias e na relação entre um conteúdo e outro a significação comece a aparecer e, aos poucos, ser possível extrair as respostas que estão sendo procuradas. Após o exaustivo recorte dos elementos e tendo em vista os objetivos da análise foram montadas as categorias cuja explicação virá na sequência. Para exemplificar como o trabalho se deu, vale a pena fazer um registro. Muitas vezes, no início das leituras, imagina-se que determinada categoria tenha de ser criada, mas ao longo da análise ela não se sustenta, e foi esse o caso da categoria criada a priori chamada "leitura crítica da mídia pela sociedade". Com o aprofundamento do estudo ela foi eliminada, pois não foram encontrados elementos suficientes que justificassem tal composição. Embora o tema tenha surgido em meio aos debates no fórum da Conferência, não foi tão relevante para se constituir em indicador de análise.

\subsubsection{Categorias de análise}

Enfim, foram criadas cinco categorias de análise: a) Liberdade e controle; b) Marco regulatório para a Comunicação; c) Acesso universal/participação social; d) Pluralidade midiática; e) Mudanças tecnológicas. Cada uma recepcionou os fragmentos de sentidos identificados no interior do material empírico tanto de um lado como do outro. No capítulo que traz os resultados e as análises, os sentidos extraídos a partir desses enunciados serão apresentados e compreendidos. Por ora, o importante é compreender que cada categoria reuniu os elementos em torno dos quais se deram os maiores embates e os possíveis consensos. Esses elementos são interpretados pela análise aplicada ao estudo, de acordo com Benetti:

Importa compreender que existe uma exterioridade que não apenas repercute no texto, mas que de fato o constitui e não pode dele ser apartada. O que fazemos ao utilizar o método da Análise do Discurso é enxergar a existência (apenas operacional e pragmática) de duas camadas: a primeira, mais visível, é a camada discursiva (que emergiu das matérias dos jornais e dos sites); a segunda, que só é evidente quando aplicamos o método, é a camada ideológica (BENETTI, 2007, p. 111). 


\subsubsection{Liberdade e controle}

Esta foi, sem dúvida, a categoria mais relevante e reveladora do estudo. Como a discussão central se deu em torno deste conceito, em torno do qual a liberdade de expressão e de imprensa dos dois segmentos é motivo de discussões há mais 50 anos, a sua classificação exigiu um maior cuidado. Durante o processo de identificação e de seleção dos temas, que passaram a ser incluídos na categoria "liberdade de expressão/liberdade de imprensa", percebeu-se que toda e qualquer afirmação ou declaração que se referisse à liberdade seja de expressão ou de imprensa, ou até mesmo de ideias, seu oposto surgia em contraponto. Por isso, em qualquer passagem de texto das matérias dos jornais ou dos sites era impossível falar em liberdade sem falar em censura ou controle. Ou seja, uma coisa está dentro da outra, ficando impossível criar uma categoria com tema tão abrangente, sem conter seu contraditório.

Após o "retorno crítico" "115 sobre o que foi construído percebeu-se que estava sendo montada uma armadilha metodológica, pois "as categorias devem possuir certas qualidades caso se queira que a análise se mostre significativa" (LAVILLE; DIONNE, 1999, p. 223). Uma dessas qualidades é a de que toda categoria deve ser "mutuamente exclusiva", ou seja, um elemento de conteúdo não pode ser encontrado em mais de uma categoria, sob pena de prejuízo dos resultados.

Se a categoria "liberdade de expressão/liberdade de imprensa" relaciona-se o tempo todo com a ameaça a esse preceito - censura ou controle -, esses dois termos passaram a fazer parte da mesma categoria. Sendo assim, passou a ser denominada "liberdade e controle" e englobou os temas que foram surgindo de cada lado do embate. Dessa forma, além de ser mais abrangente torna-se mais pertinente diante dos fragmentos recolhidos. Concluiu-se que não seria correto excluir da categoria o seu oposto.

Nesta categoria foram separados os enunciados mais relevantes dos três jornais e dos sites dos movimentos sociais, lembrando que foram recolhidos a partir dos argumentos identificados, em cada um deles, com relação à liberdade de expressão e de imprensa. Foi criada uma tabela ${ }^{116}$, em duas colunas, de modo que uma abarcasse o sentido manifestado pela mídia tradicional, acerca desses dois conceitos, e a outra o sentido manifestado pelos movimentos sociais. O significado desses enunciados está expresso no Capítulo 5 , com os resultados da análise. O importante é saber que os argumentos de cada um dos lados foram

\footnotetext{
${ }^{115}$ Esse termo foi extraído de Laville e Dionne (1999, p. 219).

${ }^{116} \mathrm{~A}$ íntegra de todas as tabelas está em anexo.
} 
contrapostos, e que a partir dos discursos revelados foi possível identificar o entendimento que cada segmento tem da liberdade de expressão e de imprensa, e especificamente o que cada um defende como liberdade para assegurar o atendimento dos objetivos e interesses dos seus representados. Os fragmentos mais relevantes serão apresentados no capítulo da Análise dos Resultados, o quadro completo está no documento em anexo. Eles estão relacionados por cada jornal ou site pesquisado.

\subsubsection{Marco regulatório para a comunicação}

Nesta categoria foram identificados os enunciados mais reveladores dos três jornais e dos sites dos movimentos sociais, lembrando que foram recolhidos a partir dos argumentos identificados em cada um deles, em relação ao que cada segmento idealiza como o marco regulatório para o País. Da mesma forma como foi feito com a categoria "liberdade e controle", foi criada uma tabela com duas colunas, de modo que uma abarcasse o sentido manifestado pela mídia tradicional, acerca do marco regulatório desejado, e a outra o sentido manifestado pelas entidades sobre o tipo de regulação que os movimentos sociais defendem.

\subsubsection{Acesso universal aos meios de comunicação e participação social}

Esta foi a categoria que apresentou mais pontos em comum entre a sociedade civil organizada e os representantes dos empresários privados de mídia, o que é bastante compreensível. Dificilmente, um porta-voz faria um pronunciamento afirmando que este ou aquele setor, ou cidadão, não deve ter acesso livre aos meios de comunicação ou que sua participação deve ser restrita. Retoricamente, os dois lados são favoráveis a que mais pessoas tenham acesso aos meios de comunicação, de modo geral, especialmente em relação à inclusão digital. Este é mais um tema em que prevalece o discurso de encobrimento da verdade. Surge o discurso fácil de que todos devem ter acesso aos meios de comunicação e que a participação do cidadão deve ser estimulada e garantia. A diferença está no tipo e na qualidade de informação que a sociedade tem acesso e que preço ela terá que pagar por isso.

Os dois lados permanecem unidos quando se trata de exigir, do Poder Público, infraestrutura para que esse acesso seja cada vez mais universal e acelerado. As diferenças começam a surgir depois que o acesso é assegurado.

Da mesma forma como foi feito com as demais categorias, foi criada uma tabela, em duas colunas, de modo que uma abarcasse o sentido manifestado pela mídia tradicional, 
acerca do acesso universal defendido, e a outra o sentido manifestado pelas entidades sobre os preceitos de universalização advogados pelos movimentos sociais.

Esta categoria levou em conta todas as questões relativas à política de massificação das TVs por assinatura, a universalização da banda larga e o acesso da população a variados tipos de informação. Além disso, englobou a ampliação dos veículos de informação e de produção de conteúdos. Temas como a participação da sociedade não apenas no consumo de mídia, mas também na produção de conteúdo foram recepcionados nesta categoria. A maneira como cada lado enxerga e entende o tipo de acesso será demonstrada no Capítulo 5, que trata dos resultados encontrados.

\subsubsection{Pluralidade midiática}

No decorrer da análise, percebeu-se que alguns conceitos eram redundantes ou poderiam ser fundidos em uma só classificação, de modo a recepcionar o maior número de fragmentos e não atrapalhar a interpretação. Foi o que aconteceu com três termos que, de certa forma se equivalem: diversidade cultural, produção cultural regional e pluralidade de conteúdos, todos reunidos na categoria denominada pluralismo midiático.

Neste quesito, também foram identificados alguns pontos de conciliação. Os grandes jornais constroem um discurso favorável no qual todos tenham voz e acesso aos meios. A dificuldade reside no momento de colocar em prática que tipo de acesso e de participação defendem as minorias, por exemplo. Enquanto as entidades sociais reclamam por uma política que valorize a regionalização do conteúdo, a mídia tradicional aposta na pasteurização da programação de cunho nacional e excludente. É nesta categoria que vamos identificar as questões alusivas ao fortalecimento das rádios comunitárias, aos veículos de pequeno porte e à produção independente.

\subsubsection{Mudanças tecnológicas}

Nas questões de cunho tecnológico o consenso foi ainda mais difícil, pois praticamente todas as questões polêmicas foram recusadas pelo instrumento da "questão sensível"117, ou seja, não foram votadas porque tanto um lado como o outro se posicionaram de modo a evitar a votação, por medo da derrota. Por isso, o assunto não avançou, mas por ser

\footnotetext{
${ }^{117}$ Este instrumento garantia que cada lado vetasse a proposta desde que contasse com pelo menos um voto do outro segmento. $\mathrm{O}$ detalhe deste instrumento está no Capítulo 2 desta tese.
} 
um tema que causou polêmica durante o encontro, foi colocado numa grande rubrica denominada "discrepâncias tecnológicas". Por causa da evolução da tecnologia estar muito à frente dos embates burocráticos e ideológicos, a briga pela divisão do espectro eletromagnético é muito feroz e o que se viu foi que o tema provocou intensas manifestações, dos dois lados, e afastou a possibilidade de consenso entre os empresários e as organizações sociais.

Esta categoria recepcionou os pontos de vista divergentes revelados pelos dois segmentos. Embora considerada polêmica, não foi muito citada nos produtos analisados, havendo certa ignorância sobre o assunto por parte de alguns interlocutores que preferiram tocar no assunto de forma superficial.

4.2.6 O jornalismo como lugar de produção de sentidos

A $\mathrm{AD}$ é "especialmente produtiva para dois tipos de estudo no jornalismo: mapeamento de vozes e identificação dos sentidos" (BENETTI, 2007, p. 107), o que justifica a escolha feita nesta pesquisa. Benetti nos ajuda a compreender como funcionam, no campo do jornalismo, alguns conceitos, que são centrais na AD. Jorge Pedro Sousa corrobora esse conceito e defende sua aplicação na análise do discurso jornalístico:

A análise do discurso dá pistas sobre as condições sociais de produção dos discursos, as situações comunicacionais concretas que originaram e constrangeram os discursos, e a relação que os discursos estabelecem com a realidade a que se referem (SOUZA, 2004, p. 9).

Ainda de acordo com Benetti, "ao compreender o jornalismo como um lugar de circulação e produção de sentidos ele é um discurso em si”. E como discurso tem as seguintes características: é dialógico, polifônico, opaco e, ao mesmo tempo, efeito e produtor de sentidos, elaborado segundo condições e rotinas particulares. O dialogismo, inerente à linguagem jornalística, estabelece dois tipos de relação: entre os discursos e entre os sujeitos (BRAIT, 1997).

“A interdiscursividade diz respeito à relação entre discursos, conceito associado a estudos sobre os sentidos; enquanto a intersubjetividade à relação entre sujeitos, lembrando que o discurso não existe por si mesmo, ele só existe em um espaço entre sujeitos" (BENETTI, 2007, p. 108). Por mais que o "dizer" produza um "efeito de literalidade" a intersubjetividade nos ajuda a recusar a ideia de que o discurso traz uma verdade intrínseca a ele. Essa impressão, segundo Orlandi (2001), de que existe um "sentido lá", literal, dando a 
impressão de que o sentido existe solto e independente, podendo ser acessado ou não, e é resultado do "apagamento da ideologia". Para Benetti:

\begin{abstract}
ideologia como ideologia - quanto mais naturalizada a ideologia, mais as formações discursivas que dela derivam carregam sentidos que parecem literais. Ora, se o discurso depende dos sujeitos para existir, isso significa que é produzido por esses sujeitos (...). O discurso é, muitas vezes, opaco, não transparente, e pleno de possibilidades de interpretação (BENETTI, 2007, p.108).
\end{abstract}

Em sua pesquisa, esse autor reforça a ideia de que o discurso jornalístico, por ser construído intersubjetivamente, exige que seja compreendido em um contexto histórico, social e político que, por sua vez, é também produtor de sentidos. E são esses sentidos que dão significado ao ser humano enquanto cidadão pertencente a um lugar. E esse lugar, no qual ele se insere, pertence a um sistema que está ligado a uma língua, a uma cultura, a uma ideologia e a um imaginário que o constitui.

O artigo de Benetti é importante para este estudo, pois retoma o conceito de jornalismo como "um modo de conhecimento" e aponta "a notícia como um dos eixos norteadores da formação de 'consensos' e parâmetros sociais de normalidade e anormalidade" (BENETTI, 2007, p. 110). A busca por consensos foi um dos parâmetros que norteou a pesquisa feita sobre os discursos construídos durante a Confecom.

Os fragmentos textuais, aqui chamados de "enunciados", foram extraídos dos textos recolhidos pelo corpus desta pesquisa, com a convicção de "que o texto é a parte visível ou material de um processo altamente complexo que inicia em outro lugar: na sociedade, na cultura, no imaginário, na ideologia" (BENETTI, 2007, p. 111). Com a ajuda do método possibilitado pela $\mathrm{AD}$ esta pesquisa foi em busca de desvelar a origem dos discursos lá inscritos, assim como a conjugação de forças que compôs o texto em estudo. É preciso lembrar que esta análise tem por objetivo ir além da primeira camada, que é visível e literal, para chegar à segunda, "que só é evidente quando aplicamos o método, que é a camada ideológica" (BENETTI, 2007, p. 111).

\title{
4.2.6.1 O processo analítico
}

Embora a $\mathrm{AD}$ pretenda ir além do que traz o texto, é a partir deste que o processo analítico tem início. "No método de análise, fazemos o caminho inverso do discurso: partimos do texto para o que lhe é anterior e exterior" (BENETTI, 2007, p. 115). É no texto que foram 
identificadas as formações discursivas (FDs) que acionaram outros sentidos, encontrados além do texto. As FDs acionam as formações ideológicas que existem anterior e exteriormente ao objeto pesquisado, e determinam as formações discursivas que foram identificadas no texto. Ou seja, é um caminho que vai e volta, sendo que na volta o analista encontra respostas para desvelar porque determinado discurso, e não outro, está impregnado naquela fala.

Foi no arquivo da história do jornalismo e da censura no Brasil que esta pesquisa encontrou a origem das FDs identificadas nos textos e, por meio delas, posicionou o discurso construído diante dos debates desenvolvidos à parte da agenda da Conferência Nacional de Comunicação. Além da busca de onde partiram tais formações, a pesquisa também não pode deixar de identificar "o lugar de fala" do sujeito, que traz com ele o discurso impresso em suas argumentações e tomadas de decisão.

Conforme mencionado, "cada enunciado é portador de um sentido" (MAINGUENEAU, 2002, p. 20). Para que o sentido seja encontrado e o enunciado compreendido, como pretende o analista, é preciso que outros saberes sejam mobilizados e identificado o seu contexto.

O que se quer dizer é que, fora do contexto, não podemos falar realmente do
sentido de um enunciado, mas, na melhor das hipóteses, de coerções para
que um sentido seja atribuído à sequência verbal proferida em uma situação
particular, para que esta se torne um verdadeiro enunciado, assumido em um
lugar e em um momento específicos, por um sujeito que se dirige, numa
determinada perspectiva, a um ou vários sujeitos (MAINGUENEAU, 2002,
p. 20).

A partir dos enunciados apartados no interior do corpus, a pesquisa foi em busca das formações discursivas (FD) nos quais eles estão inseridos, ou a partir das quais foram gerados. As FDs são basilares na análise do discurso e estão profundamente ligadas às formações ideológicas e ao jogo de poder que se estabelece no interior do discurso. As formações discursivas é que trazem em si uma posição articulada de poder, de uma classe ou outra, por isso sendo fundamental uma imersão no seu interior, para que seja possível compreender as condições de produção do discurso em análise, e a relação que ele guarda com a história e a memória no qual está inserido.

O discurso se constitui em seus sentidos porque aquilo que o sujeito diz se inscreve em uma formação discursiva e não outra, para ter um sentido e não outro. Por aí podemos perceber que as palavras não têm um sentido nelas mesmas, elas derivam seus sentidos das formações discursivas em que se inscrevem. As formações discursivas, por sua vez, representam no discurso 
as formações ideológicas. Desse modo, os sentidos sempre são determinados ideologicamente (ORLANDI, 2002, p. 43).

A identificação das formações discursivas, que alguns autores preferem chamar de "regiões de sentido", foram feitas nos textos que conformaram a base histórica desta pesquisa. Além das contribuições da professora e filósofa Marilena Chauí, que analisa a questão do poder e da mídia na sociedade contemporânea, foram analisados estudos e pesquisas da professora Carolina Matos e das historiadoras e professoras Ana Luíza Martins e Tânia Regina de Luca, entre outros.

Esse referencial histórico conformou o pequeno "arquivo" - no sentido proposto por M. Pêcheux - de que o "arquivo é o campo de documentos pertinentes e disponíveis sobre uma questão" (PÊCHEUX apud ORLANDI, 1997, p. 57), utilizado para a identificação das FDs, pois muitos desses enunciados "possuem marcas que os ancoram diretamente na situação de enunciação". Será marcado em negrito os elementos que sugerem indícios e que apontam para essas formações à luz, é claro, dos conceitos e instrumentos da Análise do Discurso.

Na revisão da história da imprensa brasileira, com foco no percurso da evolução da democracia e da censura nos meios de comunicação, serão identificadas as condições de produção do discurso hegemônico construído ao longo dos últimos 60 anos pelos proprietários dos meios. Em paralelo, serão identificadas as marcas de resistência a esse discurso e a construção do discurso contra hegemônico por parte dos movimentos e entidades sociais que lutam pela democratização dos meios desde a década de 1990.

A ideia foi criar um dispositivo analítico que relacionasse os dados históricos com as marcas da enunciação captadas pelo corpus deste estudo, de modo que fosse possível encontrar o sentido em cada um dos discursos analisados. A partir do confronto desses discursos - que se deu antes e durante a Confecom - a pesquisa foi desenvolvida.

A partir dos temas selecionados, identificados ao longo da pesquisa, foi feito o "mapeamento dos sentidos" (BENETTI, 2007, p. 112), que começa a ser identificado em meio aos textos selecionados, a partir do processo analítico. "Consideramos que uma FD é uma espécie de região de sentidos, circunscrita por um limite interpretativo que exclui o que invalidaria o sentido" (BENETTI, p. 112), e que reúne, em torno de cada FD delimitada, diversos pequenos significados que "constroem e consolidam o sentido nuclear que emerge do discurso" (BENETTI, p. 112). 
A identificação das formações discursivas consideradas nesta análise, identificadas no material empírico, deram substância para que as categorias analíticas - criadas a partir do corpus - pudessem ser construídas. 


\section{CAPÍTULO 5}

\section{O EMBATE DISCURSIVO CONSTRUÍDO DURANTE A CONFECOM}

A Conferência Nacional de Comunicação ofereceu uma rara oportunidade de confronto e diálogo entre dois lados - historicamente antagônicos - do sistema de mídia brasileiro para que as bases de um consenso em torno da regulação dos meios pudesse ser estabelecida. De um lado, o setor privado de mídia, e do outro os movimentos sociais que lutam pela democratização dos meios de comunicação.

$\mathrm{O}$ encontro aconteceu, os dois lados se enfrentaram, mas o consenso não foi alcançado. Embora tenha ocorrido um diálogo entre o segmento privado de mídia e as entidades sociais que empunham a bandeira da democratização, ele não foi suficiente para permitir o avanço nas negociações para a criação do novo marco regulatório.

Velhos entraves e impasses cristalizados pela Constituinte de 1988 vieram à tona, e cada um dos lados não conseguiu superar suas contradições e rever suas crenças e valores diante de questões centrais como a liberdade de expressão e de imprensa e o controle social da mídia.

Em face da análise feita sobre a construção discursiva deste confronto, foi possível identificar as resistências dos atores mais representativos deste embate: os que trouxeram a voz do setor privado da mídia e os que representaram o movimento social que luta pelo estabelecimento de um marco regulatório para o setor. Foi possível apurar os pontos fracos e fortes de cada posicionamento, e o ponto de vista defendido por cada segmento. A postura de cada lado mostrou que velhos argumentos levantados durante as discussões da Constituinte (1988) ressurgiram e que outros embates voltaram à tona criando uma barreira à mudança.

Depois do mergulho no corpus e da construção das categorias de análise, os resultados começam a surgir. Eles foram interpretados e analisados pela Análise de Conteúdo e pela Análise de Discurso. Essas duas escolas ajudaram a identificar e compreender os achados encontrados e neles as respostas para as perguntas desta investigação. A apresentação foi feita a partir das categorias de análise que, por sua vez, recepcionaram, de um lado, os argumentos construídos pelos movimentos sociais, a favor da regulação democrática dos meios e, do outro, os argumentos dos representantes da mídia tradicional contrários à regulação do setor.

Optou-se por expor a interpretação da análise do corpus de forma cronológica, à medida que o acontecimento foi sendo mediado pela cobertura da mídia. Como a amostra foi 
construída com material recolhido a partir do dia 4 de dezembro e se estendeu até 27 de dezembro de 2009, a apresentação acompanhou as respectivas datas. Desse material, foram extraídos os fragmentos de texto abrigados nas categorias correspondentes, como foi explicado acima.

Embora o recorte tenha sido feito nos dez dias anteriores ao início do evento e nos dez dias posteriores, alguns episódios que antecederam a Conferência foram recuperados e tratados para que fosse possível compreender como o assunto Confecom foi acontecendo midiaticamente e como os jornais e a sociedade foram se aproximando do assunto.

\subsection{Características gerais da cobertura da Confecom nos jornais e nos sites}

O assunto Confecom surgiu na grande imprensa quando se tornou inevitável, enquanto nos dois sites das entidades civis analisados ele foi a pauta principal desde a sua convocação no Fórum Social de Belém em 2009. Os jornais analisados na pesquisa: $O$ Estado de S. Paulo, a Folha de S. Paulo e O Globo, silenciaram sobre o assunto durante as reuniões preparatórias e a realização das conferências estaduais, e durante os quatro dias do evento deram pouco espaço ao assunto. Ficou claro que a estratégia do jornal era minimizar a importância do assunto. Dos três jornais pesquisados, apenas a Folha enviou um repórter especial, o que não significou que tenha dado uma atenção especial ao evento, uma vez que - entre os três jornais - a Folha, além de ter dado um número pequeno de matérias (oito) sobre a Confecom, não fez nenhum editorial sobre o tema, ao contrário dos outros dois, $O$ Globo e $O$ Estado de S. Paulo. A Folha também não deu nenhuma chamada de primeira página, ao contrário dos dois outros jornais.

Os movimentos sociais em defesa da democratização da mídia, por meio de seus principais sites, o FNDC e o Coletivo Intervozes, optaram por desenvolver uma estratégia de cobertura em duas frentes, a publicação das matérias sobre as discussões e votações de uma forma superficial, e em seguida a publicação de artigos longos contextualizando os temas e se posicionando a favor das propostas das entidades do movimento. Em todos os dias havia sempre mais de uma matéria sobre a Conferência, além de um artigo. Raramente os representantes do setor privado eram ouvidos, geralmente eles só traziam a voz daqueles que eram ligados ao movimento. A cobertura acabou por adotar uma postura de militância a favor da causa defendida, o que pode ter afastado leitores e cidadão comuns que se interessam pelo tema da comunicação. 
Essa estratégia adotada pelos sites, marcada fortemente pelo confronto, demonstrou que o movimento não se preocupou em buscar novos adeptos e ganhar mais adesões à luta empreendida. Em nenhum momento as matérias dos sites reconheceram que a sociedade não adotou essa bandeira porque, em muitas situações, a sociedade reconhece que a televisão ainda oferece o conteúdo procurado. Há a percepção de que existe um temor que algum tipo de censura seja restabelecido quando se fala em controle social da mídia; e que a internet oferece opções alternativas para quem recusa a mídia tradicional.

Além disso, em muitas ocasiões a linguagem adotada era a do passado, com adoção de codinomes antiquados como "magnatas da mídia", "oligarquia midiática" ou expressões assim, "os empresários tratam a comunicação como se fosse um latifúndio" ${ }^{118}$. Logo no primeiro dia do encontro, quando surgiu uma nova polêmica sobre o regimento, pois os empresários queriam que o quórum qualificado também prevalecesse nas votações de grupos, o Coletivo Intervozes replicou na sua página um artigo do jornalista Rodrigo Viana do Portal Vermelho ${ }^{119}$ em que este critica os movimentos sociais por terem aceitado as exigências do Grupo Bandeirantes, nos seguintes termos:

Lula acha que negocia com os donos da imprensa. Essa gente não negocia. A mentalidade dessa gente é a de fazendeiros da República Velha. A Confecom podia ser uma revolução de 30. Mas Lula não vai amarrar os cavalos no obelisco de Brasília. ${ }^{120}$

Nos meses que antecederam a Conferência, os jornais $O$ Estado de S. Paulo, a Folha de $S$. Paulo e $O$ Globo trouxeram longas matérias sobre as mudanças que estavam ocorrendo no sistema de mídia dos países vizinhos, com destaque para a Argentina e a Venezuela. $\mathrm{Na}$ ocasião, estava em debate na Argentina a Ley de Medios, que havia sido promulgada em 10 de outubro de 2009, e que suscitava intensos debates na mídia brasileira, assim como o que se passava na Venezuela, quando o então presidente, Hugo Chaves, havia decidido não renovar a concessão do mais antigo canal de televisão do país, além de ter fechado outros canais privados.

\footnotetext{
${ }^{118}$ Confecom: uma primeira vitória, uma nova etapa na longa luta, em 21\12 2009. Disponível em: http://fndc.org.br/clipping/confecom-uma-primeira-vitoria-uma-nova-etapa-na-longa-luta-471167/

${ }^{119}$ O Portal Vermelho é um site ligado ao Partido dos Trabalhadores (PT) e milita pela causa da democratização da mídia.

${ }^{120}$ Rodrigo Vianna: Lula pede e CUT cede aos empresários na Confecom, 15\12\2009. Disponível em: <http://www.vermelho.org.br/noticia/121337-6>.
} 
Embora evitassem trazer notícias sobre a Confecom, os jornais, invariavelmente, comentavam que o Brasil também poderia passar por algo parecido com o que estava acontecendo naqueles países. Algo que pudesse ameaçar a liberdade de imprensa e prejudicar a livre expressão. Mas não havia reconhecimento de que estava em andamento um processo de discussão que colocava a própria mídia brasileira em debate. Os três jornais adotaram estratégia semelhante com relação a Confecom, misturavam os assuntos, e em, praticamente, todas as matérias questionavam a legitimidade do encontro em função da desistência das seis associações de participar da conferencia, como já foi explicado no capitulo da Confecom.

Dos três jornais, a postura da Folha de S. Paulo com relação à Confecom chamou mais a atenção. Por ser o único dos três diários que mantém em seus quadros a figura do ombudsman $^{121}$, esperava-se que a Folha desse um pouco mais de espaço em suas páginas para discutir a própria imprensa. Ao contrário, o ombudsman simplesmente ignorou a Confecom, não fez nenhum comentário sobre o encontro nem no domingo seguinte ao encerramento, nem no balanço de final do ano tradicionalmente feito pela Folha. Aos domingos, rotineiramente, o ombudsman comenta a cobertura da Folha feita na semana anterior, apontando erros, deslizes e possíveis equívocos dos jornalistas. Mas no domingo que se seguiu à semana de 14 a 18 de dezembro de 2009 prevaleceu o silêncio. O que se pode concluir é que foi uma decisão empresarial tomada pelo jornal, para minimizar a importância do acontecimento. Além disso, como será apresentado adiante, sequer um editorial foi feito pela Folha sobre a Conferência ou a regulação democrática dos meios. Tratou o fato como uma coisa menor, sem desdobramentos ou consequências.

O Estado de S. Paulo e $O$ Globo, pelo contrário, optaram por enfrentar a discussão, ainda que marginalmente, nos meses que antecederam a Conferência, e com muita agressividade nos quatros dias do evento. Fizeram editoriais com graves críticas, publicaram artigos veementes e, quando podiam, "satanizavam" o encontro e insistiam que estava em curso no País uma orquestração da esquerda e dos movimentos sociais, para trazer de volta a censura e impor o controle social sobre o conteúdo jornalístico. Além de - em quase todos os dias da Conferência - deixar claro que a grande mídia estava preocupada em defender os ideais da Constituição brasileira, que poderia estar sob risco. Naturalmente, pinçavam cirurgicamente os artigos que lhes interessavam na Constituição e ignoravam aqueles que há

\footnotetext{
${ }^{121}$ Ombudsman é o representante dos leitores dentro de um jornal. A palavra é de origem sueca e significa representante do cidadão. O cargo é exercido por um jornalista da empresa que tem ampla liberdade para criticar o jornal. Ele goza de estabilidade no trabalho durante o mandato e depois de seis meses de deixar a função.
} 
mais de 20 anos estavam sendo desrespeitados pela prática do sistema midiático privado estabelecido no País.

Dos três diários pesquisados, o jornal Folha de S. Paulo foi o que cobriu o evento com menos interesse e não divulgou nada sobre o debate que estava acontecendo durante as conferências estaduais, nem mesmo sobre as propostas que começaram a surgir nas semanas que antecederam a Conferência. Do total de 13 produtos ${ }^{122}$ selecionados para o corpus, oito foram matérias pontuais sobre a cobertura, quatro foram notinhas e apenas um artigo foi publicado dez dias após o encerramento da Conferência.

O jornal $O$ Globo, que noticiou a realização do encontro com antecedência e debateu suas propostas nos meses anteriores à Confecom, durante os quatro dias do encontro publicou apenas dez produtos. Mas o conteúdo do material foi mais rico e polêmico do que o produzido pela Folha. $O$ Globo publicou dois grandes artigos criticando e alertando para os riscos sobre a independência da mídia, um enfático editorial sobre as propostas aprovadas, mas publicou apenas seis matérias pontuais e uma carta de leitor.

O jornal O Estado de S. Paulo, por sua vez, publicou 11 matérias grandes e analíticas sobre o evento e escreveu dois editoriais com severas críticas aos temas discutidos e às propostas aprovadas. Foi o jornal que mais se posicionou e enfrentou o debate, partindo para o confronto e criticando com mais ênfase a postura das emissoras de radiodifusão, especialmente as que vendem seus espaços para o proselitismo religioso. Nesse ponto, o jornal se identificou com algumas propostas das entidades sociais. Neste quesito percebeu-se uma identificação de ideias entre o movimento e parte do empresariado privado.

De modo geral, os três jornais praticamente ignoraram as conferências estaduais e o assunto só começou a ser noticiado depois que o PT lançou seu documento com as propostas que seriam levadas à Conferência, o que só aconteceu em 19 de novembro de 2009. Só mais tarde, em dezembro, no início da Conferência, é que o Jornal Nacional, finalmente, tocou no assunto, ainda assim, para lembrar que a Confecom estava se realizando sem a presença dos principais empresários da radiodifusão. Embora o Jornal Nacional não faça parte do corpus da pesquisa, é importante mencioná-lo uma vez que a matéria feita sobre a Confecom foi repercutida pelo material produzido pelos sites das entidades civis.

Os três jornais pesquisados adotaram uma estratégia semelhante para enfrentar a cobertura de um tema tão delicado como a discussão dos rumos da comunicação no país. Em primeiro lugar, fizeram matérias que misturavam e os temas e em todas elas insistiam em falar

\footnotetext{
${ }^{122}$ Deu-se o nome de produtos para sintetizar o conjunto do que foi extraído dos jornais: notas, cartas de leitores, matérias, artigos e editoriais.
} 
que a Confecom poderia trazer a censura de volta aos meios de comunicação. Em segundo lugar optaram por confundir o leitor com relação ao que é liberdade de expressão e liberdade de imprensa, e associaram automaticamente - na cabeça do leitor - que quando se fala em “controle social" da mídia na verdade está se falando de "censura à imprensa". Esta confusão propositada pelos empresários do setor, foi denominada de "estratégia da confusão" ${ }^{123}$, cujo entendimento será mostrado a seguir.

\subsection{1 "Estratégia da confusão"}

$\mathrm{Na}$ análise feita sobre o material produzido pelos três jornais escolhidos para este estudo (O Estado de S. Paulo, a Folha de $S$. Paulo e $O$ Globo), foi possível identificar que, em praticamente, todas as matérias e editoriais havia uma clara intenção de confundir o termo "liberdade de expressão" com "liberdade de imprensa" como se fossem equivalentes. Para o sociólogo, pesquisador e estudioso da Comunicação, Guareschi (2013), trata-se, na verdade, do que ele denominou de "estratégia da confusão" adotada com sucesso pela grande mídia. Segundo ele, os jornais intencionalmente querem fazer com que o leitor acredite que se trata da mesma liberdade, quando de fato a "liberdade de expressão" antecede à "liberdade de imprensa" e se trata do direito humano fundamental à liberdade de se expressar publicamente, seja por meio oral, impresso ou eletrônico.

Um exame de como se comporta a mídia, principalmente a eletrônica (rádio e televisão) em nossa sociedade vai comprovar que a grita pela liberdade de imprensa", é perigosa e às vezes propositadamente confundida com a liberdade de expressão, recorrente a todo o momento (GUARESCHI, 2013, p. 81).

A discussão e o esclarecimento do que diferenciam essas duas liberdades, segundo Guareschi (2013, p. 95), "desnuda a hipocrisia discursiva dos coronéis da mídia brasileira”. Uma das explicações para que prevaleça essa confusão intencional entre estes conceitos, "está na força e no círculo de ferro que a grande mídia exerce tanto no que pode ou deve ser publicado como no que consegue ser divulgado" (GUARESCHI, p. 95). Para o professor, além da hipocrisia dos donos da mídia se soma a dominação que se exerce sobre o que é publicado e discutido pela imprensa.

\footnotetext{
${ }^{123}$ O professor e pesquisador Pedrinho Guareschi chamou de "estratégia de confusão" a postura adotada pela grande mídia de confundir, intencionalmente, a liberdade de expressão com a liberdade de imprensa.
} 
Para reforçar a adoção desse tipo de estratégia, o também estudioso e pesquisador, Lima (2010), explica que os jornais ignoram, ou fingem ignorar, a origem e a história dessas duas naturezas de liberdade, exatamente para confundir o leitor.

Apesar de estarmos no século XXI, diante de uma realidade radicalmente diversa daquela em que viveram os que primeiro teorizaram sobre a liberdade de expressão e a liberdade de "imprimir" (printing) os grandes grupos de mídia brasileira continuam a evocar anacronicamente os clássicos liberais em defesa de suas posições e contra tudo o que consideram ameaçar os seus interesses privados (LIMA, 2010, p. 126).

Um destes clássicos, sempre lembrados nessas ocasiões, é Areopagitica, de John Milton, de 1644. Nele, Milton se refere ao "direito natural do indivíduo de expor e imprimir suas ideias" e fala a capacidade individual e do livre-arbítrio de cada de ser humano de expor seus pensamentos. Segundo Lima,

a Areopagítica, por óbvio, não poderia estar se referindo à imprensa, no seu significado moderno: primeiro porque no texto não há referência a press, mas sim a printing; e segundo, porque na Inglaterra do século XVII não existiam "jornais" - e muito menos, empresas comerciais de mídia (de meios impressos e/ou eletrônicos), no sentido contemporâneo em que (ainda) é empregada a palavra imprensa (LIMA, 2010, p. 23)

É tão grave essa confusão de conceitos, que a falta de uma distinção clara entre um e outro, além de gerar equívocos (propositais ou não) acaba por provocar decisões que geram ainda mais confusão como foi o julgamento do fim da Lei de Imprensa ocorrido em 2009. O Supremo Tribunal Federal (STF) optou pelo fim da Lei da Imprensa, criada na época da ditadura militar, por entender que ela, entre outras coisas, limitava a liberdade de imprensa. Embora Guareschi entenda que faltou aos ministros do STF “o discernimento cuidadoso" para distinguir um conceito do outro, eles acabaram por "colaborarem na perpetuação danosa dessa confusão" (GUARESCHI, 2013, p. 96).

Ao que parece os ministros do STF fizeram o que fizeram não por descuido ou confusão, e sim por incorporarem o ponto de vista defendido pelos grandes jornais, a quem é bastante conveniente que um conceito seja misturado ao outro. Para o professor Lima (2010), "a ausência de rigor conceitual constata-se pelo fato de os ministros terem sustentados os seus argumentos em editoriais dos três principais grupos empresariais de mídia do país, $O$ Globo, a 
Folha de S. Paulo e O Estado de S. Paulo" (LIMA, 2010, p. 129). Com base no que defendiam estes jornais sete ministros votaram pelo fim da Lei de Imprensa, alegando que a imprensa brasileira é livre e plural e ainda “...é uma imprensa que faz de sua liberdade de atuação um necessário compromisso com responsabilidade quanto à completude e fidedignidade das informações comunicadas ao público" (APDF nº130, § 29 apud LIMA, 2010).

O parecer do relator foi tão de acordo com os interesses dos empresários do setor que Venício Lima chegou a expressar uma provocação em seu livro sobre o tema: "Estão os ministros falando do mesmo país e da mesma mídia”? Para Lima,

\begin{abstract}
A quase totalidade das considerações dos ministros foi feita no pressuposto de que o Estado representa uma ameaça permanente sobre a liberdade de expressão e a liberdade de imprensa. A maioria ignora, por exemplo a conhecida argumentação desenvolvida pelo jurista americano, professor em Yale, Owen Fiss (1996/2005), sobre o papel do Estado como garantidor dessas liberdades (apenas dois ministros lembraram Fiss). Ignora-se também que, nas sociedades contemporâneas, essas ameaças têm partido, sobretudo, da autocensura e dos próprios conglomerados de mídia (LIMA, 2010, p. 132).
\end{abstract}

\title{
5.2 Como foi a cobertura nos jornais
}

Como já foi colocado, O Estado de S. Paulo, a Folha de S. Paulo e O Globo adotaram uma estratégia similar em muitos momentos para fazer a cobertura da Confecom. Ao mesmo tempo em que se sentiam compelidos a cobrir o assunto, não queriam dar a ele a dimensão que ele exigia: pois era a mídia sendo discutida pela própria mídia. Os três têm uma característica em comum: a marca ideológica que definiu a trajetória de cada um deles ao longo da história do país. E essa marca se fez presente na forma como a cobertura se deu.

Embora todos eles reiterassem o tempo todo a defesa da liberdade de expressão e a resistência contra o controle social da mídia, eles escondiam que por trás destas bandeiras, estava a certeza de que, em primeiro lugar, prevalece a liberdade da empresa de mídia de fazer o que bem deseja com a informação e não ter que estar sujeitos a acompanhamentos, controles ou supervisões por parte da sociedade. Os empresários de mídia alegam que a liberdades de expressão e de imprensa já estão asseguradas sem a necessidade de qualquer intervenção por parte do Governo ou do Congresso Nacional, e que tudo isso está garantido na Constituição Federal. 
Ao mesmo tempo, porém, resistem e são contrários à regulamentação dos artigos. 221, 222 e 223, do Cap. V da Constituição Federal. Sofismam quando falam em liberdade de expressão como preceito constitucional e desejam perpetuar uma situação de dominância do setor privado de mídia sobre o campo da comunicação, sem espaço para qualquer complementariedade. Ao longo das matérias, editoriais e artigos os três jornais, sem exceção, se esmeraram em construir um jogo de palavras, que evidencia o encobrimento das reais posições e intenções do empresariado.

O jornal O Estado de S. Paulo repetiu que a Confecom defendia a tese do controle social da mídia com a criação de conselhos de comunicação e que isso seria inconstitucional. “O risco real e presente é que a hora seja ajustada para marcar a guinada autoritária que seus adeptos tentaram instituir no primeiro mandato de Lula, com o projeto chavista do Conselho Federal de Jornalismo..."124. Ocorre que a própria Constituição prevê a criação de um conselho de comunicação. Nesta hora, os empresários encobrem esta verdade que está no texto da Constituição. De certa forma, seja Conselho de Comunicação Social, como prevê o artigo 224 da Constituição Federal, ou Conselho Federal de Jornalismo, como chegou a ser proposto pela Confecom, o temor dos empresários é semelhante.

Os discursos dos empresários, marcadamente comprometidos com o atraso, deixam claro a marca ideológica do encobrimento do real pensamento do segmento de mídia, o mesmo construído durante os debates da Constituinte. Os proprietários dos grandes jornais aqui analisados fingem que querem obedecer ao texto constitucional, fazem publicamente a defesa Constituição, mas quando são confrontados com os artigos que lá estão a espera de regulamentação, alegam que a livre iniciativa está sob ameaça e que a censura pode voltar sob a tutela do próprio Poder Executivo.

A todo o tempo querem assustar a sociedade de que a censura do passado, praticada durante o regime militar, pode voltar com o estabelecimento dos conselhos ou dos observatórios de mídia. É uma evidente luta pela manutenção do poder que insistem em deter sobre a informação, quando a própria história e a revolução tecnológica já mostraram que este poder já foi descolado e hoje transcende e orbita em fronteiras móveis. A tradicional força dos aparelhos privados de hegemonia, até há pouco tempo instalados nos grandes conglomerados midiáticos como a TV Globo, perderam a sua força e já não ditam, com a mesma supremacia de antes, os caminhos a serem seguidos.

\footnotetext{
${ }^{124}$ Confecom e o 'controle social' da mídia, O Estado de S. Paulo, 16/12/2009, p. A6.
} 
Quando em agosto de 2009 as principais entidades que representam a mídia privada, como a ANJ e Abert, deixaram a Conferência, elas alegaram que estavam saindo porque não aceitariam discutir nenhum assunto que afrontasse a Constituição brasileira. E que a Confecom assim o faria. Todavia, toda a discussão teve como eixo central o capítulo da Comunicação na Constituição. Foi mais um véu para encobrir a verdade, uma vez que os proprietários de mídia, ao longo das duas últimas décadas, se empenharam para que essa mesma Constituição fosse desrespeitada, e que os seus preceitos como controle da concessão de outorgas, "o estabelecimento de meios legais que garantam à pessoa e à família a possibilidade de se defenderem de programas ou programações de rádio e televisão que contrariem o disposto no art. 221, bem como da propaganda de produtos, práticas e serviços que possam ser nocivos à saúde e a meio ambiente" (CF, art. 220) fossem definitivamente esquecidos.

Sob o cristalizado argumento de que defendem acima de tudo a liberdade de imprensa e de expressão, os empresários escondem que, na verdade, defendem é a liberdade empresarial de manter o controle da informação e usar essa informação para manipular a opinião pública e garantir os seus oligopólios e sua permanente influencia junto ao Governo, qualquer que seja ele.

Embora o denominador comum a estes jornais seja extenso, ainda assim cada veículo mostrou as suas particularidades. Foi feita uma análise, em separado, de cada um dos jornais, como segue adiante.

\subsubsection{O jornal $O$ Estado de S. Paulo diante da Confecom}

O jornal $O$ Estado de S. Paulo, apesar de estar sendo vítima (na ocasião) da censura judicial obtida pela família Sarney, para impedir a divulgação da investigação Boi Barrica ${ }^{125}$, evitou falar sobre a Confecom, que abordaria o tema da censura. Embora tenha publicado durante os meses de outubro, novembro e dezembro de 2009 várias matérias e artigos sobre a liberdade de expressão e a censura que estava sofrendo, o jornal não fez qualquer relação

\footnotetext{
${ }^{125}$ Este foi o nome dado a uma operação da Polícia Federal que investigou o empresário Fernando Sarney, filho do senador José Sarney, suspeito de operações de lavagem de dinheiro durante a campanha de sua irmã, Roseana Sarney, ao governo do Maranhão. A investigação recebeu este nome em referência a um grupo de folclore do estado que tem como padrinhos a família Sarney.
} 
entre um assunto e outro. Esse assunto, inclusive, foi levado à Confecom e na ocasião foi aprovada uma moção de repúdio à ação do Poder Judiciário e à família Sarney.

Durante o mês de setembro de 2009, o jornal publicou várias matérias sobre as mudanças na legislação, que estavam sendo aprovadas na Argentina, e não fez qualquer referência à Confecom, mas aproveitou para reforçar que o cenário era ameaçador para as liberdades no continente latino-americano, mas preferiu não tratar diretamente do assunto. Como o jornal já estava sob censura judicial, seria natural optar pelo tema da censura, seja judicial ou de outra natureza, mas não o fez. Indiretamente, todavia, o diário paulista começou a se aproximar do acontecimento Confecom.

Em 10 de setembro de 2009, em pequena chamada na primeira página, o jornal $O$ Estado de S. Paulo convida para um artigo do jornalista Eugênio Bucci ${ }^{126}$, no qual critica o uso da TV pública pelo Governo, como se o canal fosse oficial e não público. Bucci (2009), que já foi presidente da Radiobrás, atualmente Empresa Brasil de Comunicação (EBC), entre janeiro de 2003 e abril de 2007, critica a decisão da TV Cultura de ter permitido que sua programação fosse interrompida para passar quatro minutos de um discurso do então governador José Serra. O artigo defende a TV pública e alega que ela "pertence à sociedade e não ao Governo.” Segundo Bucci (2009), “do governo, qualquer governo, a TV pública deve saber manter distância. Se não for crítica e independente, ela é apenas desnecessária, porque irrelevante”. O artigo chega a ser dúbio com relação à importância da TV Pública, todavia o que chama a atenção é a autoria do artigo. Quem é de fato, Eugênio Bucci?

Não foi por acaso que este artigo foi escrito por Eugênio Bucci. Ele não é apenas um jornalista que é professor do Departamento de Jornalismo da ECA (USP). Naturalmente, quando o leitor se depara com um artigo de um professor de uma universidade de prestígio como a Universidade de São Paulo (USP) ele tende a dar credibilidade, tanto ao jornal como ao teor do texto publicado. É uma estratégia dos jornais, de uma forma geral, encarregar pessoas com prestígio para tratar de assuntos que são caros à empresa. Neste caso, a questão ainda é mais delicada, pois Bucci era um petista histórico ligado ao ex-presidente Lula, que o nomeou para ser presidente da então Radiobrás (atualmente EBC) de 2003 a 2008. Na ocasião, Bucci comungava da ideologia do Partido dos Trabalhadores, que defendia em seu programa a regulação democrática da mídia.

Mas, desde 2008, Bucci mudou de lado e passou a falar em nome dessa mesma mídia, foi quando passou a fazer parte do quadro de articulistas do jornal $O$ Estado de S. Paulo.

\footnotetext{
${ }^{126}$ TV pública não é do Governo, O Estado de S. Paulo, 10/9/2009, p. 11.
} 
Além de não ser mais petista ele passou a fazer severas críticas ao partido e à condução do governo, e passou a escrever artigos controversos que renderam polêmicas nas redes sociais e também nas revistas de circulação nacional.

Em 26 de dezembro de 2013 Bucci publicou em sua coluna no jornal $O$ Estado de $S$. Paulo um artigo que, certamente, contrariou os petistas:

A oratória petista depende de ter um antagonista imaginário. Sem isso, parece que não para mais de pé. Sim, temos aí um traço de discurso autoritário. Em todo regime autoritário ou totalitário, a figura mais essencial é a do inimigo. Para os nazistas, esse inimigo estruturante foram os judeus. Para o chavismo, foi o imperialismo, encarnado por Bush, que teria cheiro de enxofre. E mesmo Bush só conseguiu salvar seu mandato do fiasco porque lhe caiu no colo o inimigo chamado terrorismo. É claro que não se pode dizer que o PT atualmente se reduza a um discurso tropegamente autoritário, mas as feições autoritárias e fanatizantes desse discurso vão ganhando densidade a cada dia. Não obstante, está assentado em bases fictícias, completamente fictícias vale frisar este ponto: sem um inimigo para chamar de seu, esse tipo de ossatura ideológica se liquefaz. O que seria dos punhos cerrados dando soquinhos no ar sem o auxílio luxuoso do inimigo imaginário? O que seria dos sonhos de martírio em nome da causa? O que seria das fantasias heroicas e do projeto ambicioso de virar estátua de bronze em praça pública? (O ESTADO DE S. PAULO, 26/12/2013) (27 $^{127}$

O professor, que participou da Confecom, Gabriel Priolli Neto ${ }^{128}$, respondeu a Bucci em seu blog:

Confesso que sinto um considerável desconforto quando vejo Eugenio se referir ao petismo com essa alteridade impossível para quem, como ele, foi militante do PT a vida toda e funcionário em elevado cargo de confiança no Governo Lula. Mas o que interessa são os argumentos do colega e amigo, e se discordo deles, cabe rebatê-los. Primeiramente, observo que a imprensa não é criticada por converter-se formalmente em partido político, algo que, mesmo querendo, lhe seria impossível. A imprensa é criticada por agir partidariamente, por ter como único foco de crítica o PT e sua aliança governista federal, e por pautar o discurso e as ações dos partidos de oposição contra o governo petista. Desde Lula e agora sob Dilma (...) Bucci acredita que a crítica ao partidarismo da imprensa está assentada "em bases fictícias, completamente fictícias". Mas ela cumpriria uma função política. $\mathrm{Na}$ falta de uma oposição de verdade que pudesse servir de vilã cruel, na falta de um satanás mais ameaçador para odiar (a 'herança maldita' de FHC não funciona mais como antagonista imaginária), querem fazer valer essa

\footnotetext{
${ }^{127}$ Dos que tanto amam odiar a imprensa, Eugênio Bucci. O Estado de S. Paulo, 26/12/2013.

${ }^{128}$ Priolli Neto, que é jornalista e professor, também já trabalhou para empresas da grande imprensa, como a TV Globo, Record, e o jornal O Estado de S. Paulo, mas dedicou maior parte de sua carreira a atividades ligadas à TVs ligadas às universidades, e também à Associação Brasileira de Produtoras Independentes de Televisão. Acompanhou a realização da Confecom e publicou artigos no Coletivo Intervozes durante o evento. Atualmente tem um blog e é produtor independente de televisão.
} 
ficção ufanista de que o País vai às mil maravilhas, só o que atrapalha a felicidade geral é esse maldito partidarismo da imprensa. ${ }^{129}$

Voltando ao período da Confecom, no mesmo dia em que o jornal paulista publicou o artigo de Bucci, foi publicada uma matéria na qual o então presidente do Senado, José Sarney, acusa a mídia de ser “inimiga das instituições”. Segundo Sarney (2009), “a mídia diz que é ela que representa o povo, mas quem representa o povo somos nós", em referência aos parlamentares eleitos. ${ }^{130}$

Como já foi dito, o jornal $O$ Estado de S. Paulo, estava sendo vítima de censura judicial, porém, mais uma vez, perdeu a oportunidade de colocar este tema no centro do debate que iria acontecer na Confecom. Em editorial no final de outubro, $O$ Estado de $S$. Paulo $^{131}$ fez críticas ao presidente Lula e ao modo como ele tratava os jornais. Mas nem nesse editorial o jornal fez referência à realização de uma Conferência que iria discutir a própria mídia. E porque o jornal optou por não comentar sobre a Confecom, uma vez que seria pertinente comentar sobre a sua realização em face da discussão sobre a censura que o jornal estava sofrendo? Esta decisão editorial confirma que os grandes jornais aqui analisados fizeram a opção pelo silêncio. Silenciar sobre a Confecom foi a estratégia encontrada pelo jornal para não ter que reconhecer a importância de a mídia discutir a própria mídia, tanto os seus limites como as suas possibilidades. O que o jornal deixou de dizer também revela a postura que o jornal adota quando se trata de discutir assuntos que tenham relação com os princípios básicos do jornalismo.

No dia 27 de setembro de 2009, o jornal O Estado de S. Paulo publicou uma matéria, no mínimo, de caráter dúbio. Com uma pequena chamada na primeira página, o jornal enaltece as qualidades do jornalista e ex-ministro do Governo Lula, Franklin Martins, publicando uma foto de meia página, em duas colunas no interior do jornal, afirmando que o conselheiro estava ampliando seus poderes junto ao presidente Lula. Mas ao mesmo tempo criticou a criação da EBC cujo projeto teve a participação ativa de Franklin Martins. O jornal diz que a "EBC é uma instituição anêmica e que seu conselho curador é meramente decorativo". ${ }^{132}$

\footnotetext{
${ }^{129}$ Bucci diz que mídia não age como partido de oposição; Priolli Neto rechaça. Disponível em: <http://www.viomundo.com.br/politica/eugenio-bucci-diz-que-midia-nao-age-como-partido-de-oposicaogabriel-priolli-rechaca.html>, acesso em: 5 jan. 2014.

${ }^{130}$ Quem representa o povo, O Estado de S. Paulo, 10/9/2009, p. 11.

${ }^{131}$ O mentor da imprensa, O Estado de S. Paulo, 31/10/2009, p. 3.

${ }^{132}$ Franklin, o conselheiro amplia poderes, $\boldsymbol{O}$ Estado de S. Paulo, 27/9/2009, p. 10.
} 
$\mathrm{Na}$ intenção de começar uma aproximação com o tema da Confecom, e ao mesmo tempo se justificar pelo não tratamento do assunto até meados de novembro de 2009 , o jornal publicou no dia 19 de novembro de 2009, um longo artigo assinado, mais uma vez, pelo jornalista Eugênio Bucci, no qual ele critica a cobertura que a imprensa tradicional está dando à preparação da Conferência, alertando que o "evento poderá ter importância histórica". Segundo Bucci (2009), "o assunto é grave demais para ser negligenciado". Na verdade, o que ele critica é a "não cobertura". 133

$\mathrm{O}$ artigo de Bucci, no fundo, ao falar da Confecom quer criticar a pauta da Conferência, e até mesmo a sua realização, e ainda aproveita para criticar as entidades que encabeçam o movimento. Para Bucci (2009), a sigla Confecom é muito hermética e afasta o tema da sociedade. O pior é que ele acha que não é por acaso que isso aconteceu. $\mathrm{O}$ articulista questiona se a "esquisitice" do nome não seria um "sintoma ideológico de uma cultura estatal que tende a denominar (para dominar) os movimentos sociais que, supostamente, teriam que ser autônomos". Bucci (2009) acredita que o interesse pela Confecom é maior por parte do Estado do que, exatamente, dos movimentos sociais que, há anos, defendem a realização da Conferência. Ele sugere que o Estado estaria usando os movimentos para atingir o seu objetivo de controlar a mídia.

O artigo segue o caminho da provocação. Segundo Bucci (2009),

muitos já perguntaram se a Confecom seria uma iniciativa da sociedade, que foi abrigada, mas não controlada pelo Governo, ou se esse gosto por uma sigla oficial seria uma tática do Governo, por meio de voluntários da sociedade civil.

Embora tenha lançado dúvidas sobre a autoria da convocação da Conferência, o jornalista não descarta sua importância e necessidade, assim destacou Bucci (2009),

A pauta da Confecom corresponde ao mais alto interesse nacional. Trata-se da mais ambiciosa iniciativa encampada por um governo, pelo menos desde o golpe de 1964, para debater o ordenamento da comunicação social no País. Não é pouca coisa. ${ }^{134}$

Segundo Bucci (2009), “o debate é urgente e necessário, e já está em marcha”. Ele afirma que cada um dos mil e quinhentos delegados que virão a Brasília para o encontro, "é portador de reivindicações e propostas sobre este tópico que é central, que é estrutural da

\footnotetext{
${ }^{133}$ O tabu e o interesse nacional, O Estado de S. Paulo, 19/11/2009, p. 3.

${ }^{134}$ O tabu e o interesse nacional, O Estado de S. Paulo, 19/11/2009, p. 3
} 
nossa democracia: os marcos legais que regulam a comunicação no País, da radiodifusão à internet de banda larga" (BUCCI, 2009).

$\mathrm{O}$ artigo faz um retrospecto breve e interessante sobre a dificuldade de se colocar o tema em debate, e acredita - aliviando o lado dos empresários - que "a explicação para os silêncios do noticiário passa mais pelo imobilismo da imprensa de noticiar processos contraditórios do que por um boicote patronal" (Idem).

Até outro dia, diz ele, o tema era tabu, até mesmo na Esplanada dos Ministérios. De que forma é possível limitar a propriedade cruzada dos meios de comunicação? Como superar os monopólios e os oligopólios? Já vi ministros de Estado empalidecerem ao som dessas indagações. Agora são os ministros que tomam a dianteira da Confecom. O que mudou? ${ }^{135}$

Bucci (2009), em $O$ Estado de $S$. Paulo, acredita que a imprensa deveria aceitar a Confecom como um fato e lidar com isso. O problema é que "os fatos se mostram por demais ambíguos aos óculos convencionais da nossa cultura jornalística - e ela não sabe direito como tratá-los." Uma das razões de tal dificuldade, acredita, é de origem. "A Confecom é uma iniciativa da sociedade, independente do Estado, ou é um comício a serviço do Governo?” E ainda acrescenta: "É um movimento a favor da liberdade de expressão ou uma gritaria para intimidar, em nome do poder, as redes de TV comerciais?".

$\mathrm{O}$ artigo cobrou "dos representantes das ONGs e movimentos sociais, que encabeçam a Confecom, um posicionamento mais firme contra a censura judicial ${ }^{136}$ que prejudica tanto grandes jornais como pequenos blogs". Por fim, depois de ressaltar que a Confecom poderia ir tanto para o lado "das propostas stalinistas" como para outro, "o das propostas democráticas", Bucci (2009) advertiu que seja como for,

cabe à imprensa responder, o que não pode é desperdiçar a chance de investigar e debater, em profundidade e criticamente, esse imenso atraso da nossa democracia: a ausência de marcos regulatórios modernos para a radiodifusão e a comunicação. Existem erros enormes na Confecom, mas silenciar sobre ela será um erro bem maior (Idem).

Quando um articulista usa a expressão "propostas stalinistas" ele quer que o leitor acione na memória a lembrança das práticas fascistas perpetradas pelo ditador russo Josef

\footnotetext{
${ }^{135}$ O tabu e o interesse nacional, O Estado de S. Paulo, 19/11/2009, p. 3

${ }^{136}$ É importante lembrar que nessa ocasião o jornal $O$ Estado de $S$. Paulo estava sofrendo censura, determinada judicialmente, que impedia a publicação de qualquer matéria sobre a fiscalização que o filho do ex-presidente do Senado, José Sarney, estava sofrendo por parte da Polícia Federal, denominada Boi Barrica.
} 
Stalin, que governou a extinta União Soviética por quase 25 anos. O jornalista, quando escolhe usar esse termo, aciona a formação discursiva que contém esse significado. Para quem conhece a história daquele país sabe que "propostas stalinistas" preveem censura à imprensa, fim das liberdades individuais e exílio de líderes non gratos pelo poder estabelecido, além de outros conceitos de cunho autoritário.

Só em 22 de novembro de 2009, um domingo, a 21 dias do início da Conferência, o jornal $O$ Estado de S. Paulo deu uma chamada na primeira página, mas de apenas três linhas, na parte inferior, comentando a realização da Confecom. Não foi um simples comentário, pois a pequena chamada é opinativa e convida o leitor para um editorial com o seguinte tema: “A convocação da Confecom é oportuna, mas o cenário está longe de ser promissor". Na página 3, dedicada ao pensamento da empresa, o editorial, que ocupa meia página do jornal, em quatro largas colunas, alerta o leitor sobre uma possível ameaça à liberdade de imprensa que estaria em gestação na Confecom:

Esse risco está presente na Confecom. Já despontam algumas "teses" mal costuradas, bem típicas, aliás, que vão do esquerdismo mais fora de moda ao fascismo mais grotesco. Em comum, essas teses conclamam o Estado a, aberta ou veladamente, decidir que notícias - ou programas - devem ou não ser veiculadas por uma emissora de rádio ou de $\mathrm{TV}$, prática comum nos regimes totalitários, mas inadmissível no mundo democrático. ${ }^{137}$

O editorial, como se sabe, é um espaço nobre dentro do jornal, pois é nele que os donos do jornal se posicionam e defendem suas ideias e apostam nessa ou naquela tendência cujo assunto esteja em debate. Lembrando Traquina (1999, p. 234), o jornal tem a liberdade e o direito de exprimir sua opinião acerca dos tópicos que lhe interessa, assegurando que

...as próprias declarações e pensamentos do jornal acerca de um acontecimento - o produto do juízo editorial - estão representados na linguagem pública do jornal, da mesma maneira que as afirmações dos definidores primários. O processo é muito semelhante. (TRAQUINA, 1999, p. 234).

Todavia, há outro modelo de editorial, ao qual o escritor se refere, que tem muito a ver com o tipo de editorial que está aqui em análise e é muito comum no jornalismo brasileiro:

Há um segundo tipo de editorial que vai além da expressão dos seus próprios pontos de vista num idioma público e que, de fato, proclama estar a expressar os pontos de vista do público. Chamamos a este processo mais

\footnotetext{
${ }^{137}$ O tabu e o interesse nacional, O Estado de S. Paulo, 19/11/2009, p. 3
} 
ativo de falar pelo público (em oposição a simplesmente utilizar um idioma público). Algumas vozes desses editoriais são tão distintas que seria mais preciso falar delas como a própria voz do jornal. Contudo, é improvável que tal voz seja sempre completamente independente na sua retórica do sentido do editor acerca do idioma público do seu presumível público. A essência da diferença é a existente entre o editorial que diz "nós acreditamos..." e o que diz "o público acredita...". Esse "falar pelo público", essa forma de articular o que se supõe que a vasta maioria do público pensa, esse inscrever da legitimidade pública nas perspectivas que são expressas pelo próprio jornal representa os media no seu papel mais ativo de fazer campanha - o ponto onde os media mais ativa e abertamente modelam e estruturam a opinião pública. (TRAQUINA, 1999, p. 234)

Traquina ainda acrescenta que, qualquer que seja a forma do editorial, a mídia estabelece uma ponte de mediação crucial entre o aparelho de controle do Estado, as grandes empresas ou o público em geral. Desse modo, a imprensa tem o poder de legitimar e reforçar as ações dos poderosos, trazendo seus próprios argumentos - supostamente independentes - a respeito do que está sendo discutido, de modo a influenciar a opinião pública na defesa dos seus próprios interesses. Por terem construído uma áurea de que a imprensa brasileira adotou o modelo do jornalismo norte-americano, especialmente a partir do início do século $\mathrm{XX}$, de que os princípios liberais da busca de isenção, objetividade e neutralidade são perseguidos e orientam a prática jornalística, os jornais ainda tentam convencer seus leitores das suas boas intenções.

Depois de considerar positiva a iniciativa do Governo de convocar a Conferência, o jornal argumenta que "está presente na Confecom o risco de que teses mal costuradas, típicas do esquerdismo mais fora de moda, ao fascismo mais grotesco" pudessem prosperar ${ }^{138}$. Enunciados como este são destacados no editorial pela pesquisa, pois remete à formação discursiva ideológica de que tanto o jornal como o leitor entendem como possível ameaça à democracia a volta da censura à imprensa, ativando a memória do recente período ditatorial vivido no País (1964/1985).

Infelizmente existem militantes profissionais dos "movimentos sociais" que ainda não entenderam uma obviedade da civilização: nenhuma autoridade estatal recebe mandato ou delegação para ditar o que a sociedade vê, ouve, enuncia ou debate. $\mathrm{E}$ os que marcham contra a liberdade de imprensa, pedindo mais censura, violentam a cultura democrática. Qualquer clamor autoritário é inadmissível quando se trata de regulamentar a comunicação social. Nessa matéria, tudo há que tender para maior liberdade. ${ }^{139}$

\footnotetext{
${ }^{138}$ Os riscos da Conferência da comunicação, editorial $\boldsymbol{O}$ Estado de S. Paulo, 22/11/2009, p. A3.

${ }^{139}$ Os riscos da Conferência da comunicação, editorial $\boldsymbol{O}$ Estado de S. Paulo, 22/11/2009, p. A3.
} 
Nesse caso, o editorial se impõe como um espaço de autoridade e de defesa das liberdades democráticas, acima de qualquer questionamento, arguindo uma legitimidade que supõe possuir.

Sempre que possível o editorial usa a estratégia de desqualificação do discurso do outro, o que é comum num discurso opinativo como o do editorial. Ao afirmar que os movimentos sociais ainda não "entenderam uma obviedade da civilização, de que nenhuma autoridade estatal recebe mandato da sociedade para decidir por ela o que ouve, vê ou enuncia..." deixa clara sua condição de superioridade no confronto do discurso, quando acusa o outro lado - os representantes dos movimentos sociais - de desconhecer uma verdade que é óbvia.

Apesar de reconhecer que os monopólios e oligopólios são "nefastos porque atentam contra a liberdade de iniciativa e sufocam a livre concorrência, e são contra a liberdade de imprensa, uma vez que limitam a diversidade de vozes", o editorial propõe que cabe ao Estado "zelar pelo regime que preserva a liberdade", mas não diz como, não vai além. Também é contraditório, pois pouco antes havia argumentado que "nenhuma autoridade estatal recebe mandato ou delegação para ditar o que a sociedade vê". Se a autoridade não pode regular, como afirma no editorial, ao mesmo tempo adverte que "cabe ao Estado zelar pelo regime que preserva a liberdade”. E para preservar essa liberdade e garantir que seja exercida em sua plenitude, é preciso que seja fiscalizada e garantida, não podendo apenas ficar na intenção e no espontaneísmo dos meios e das publicações. O que se discutiu na Conferência foi exatamente criar conselhos municipais, estaduais e federal para acompanhar e garantir que a imprensa seja livre, democrática e se responsabilize por tudo o que divulgar, como acontece em países modernos e desenvolvidos. O curioso é que o editorial pede pela regulamentação, mas rechaça a ideia de qualquer tipo de acompanhamento ou fiscalização do trabalho da imprensa. Prefere associar os instrumentos de regulação à censura.

Para concluir, o editorial aconselha: “o Estado poderia fazer mais se desistisse dos ímpetos controladores nos quais ainda tem incidido (...), quando tenta instrumentalizar as emissoras públicas sob sua esfera de influência...”. E adverte que não é de se descartar “a ameaça de que a Conferência seja manipulada por setores governamentais que, cooptando movimentos organizados, procuram perpetrar investidas contra o setor privado - como vem acontecendo em países deste continente" ${ }^{140}$ (em referência à Argentina e à Venezuela que, naquele ano, tomaram medidas que afetou as empresas de mídia daqueles países)

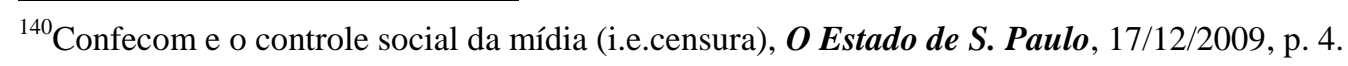


Todos esses enunciados - presentes nos fragmentos analisados - referem-se a formações discursivas que estão presentes na história recente do País, que viveu de 1964 a 1985 um período ditatorial que impôs pesada censura à imprensa, cujas referências históricas estão presentes no capítulo que traz a contextualização da pesquisa. $\mathrm{O}$ editorial quer mostrar à opinião pública que a liberdade de imprensa poderia estar sendo ameaçada pelas propostas dos movimentos sociais presentes à Confecom, mas esqueceu que os movimentos sociais foram os mesmos que participaram da luta para que a ditadura tivesse um fim, bem como todas as liberdades, não só a de imprensa, pudessem ser resgatadas. O editorialista usa e abusa da estratégia discursiva de um editorial com a finalidade de buscar certa aproximação e intimidade com a sociedade, colocando-se ao lado desta como possível vítima da volta da censura.

Uma semana depois desse editorial, em 29 de novembro de 2009, um domingo, em longa matéria de 150 linhas e com chamada na primeira página, o jornal publica uma matéria assinada por dois jornalistas, intitulada "Conferência quer intervir na mídia". ${ }^{441}$

No lead (primeiro parágrafo da matéria) está escrito que:

a maioria das propostas encaminhadas pelos ministérios, sindicatos e organizações não governamentais à $1^{\text {a }}$ Conferência Nacional de Comunicação (Confecom) quer mais regulação do Estado sobre a mídia e, principalmente mais favores do Governo. ${ }^{142}$

É clara a intenção do jornal de associar a possível interferência do Estado na estrutura de comunicação do país, a uma prática clientelista, e até histórica, de que a criação de qualquer mecanismo de controle implique o surgimento de novas instâncias e a contratação de mais servidores, que seriam favorecidos pelo Governo. Por essa razão, logo no início dos trabalhos da Confecom, o jornal O Estado de S. Paulo publicou uma matéria criticando as propostas de recriação da Embrafilme ou de delegacias regionais do Ministério das Comunicações sob a alegação de que seriam criados "mais cabides de emprego".

Nessa matéria o jornal ouviu cineastas contrários à ideia e convidou vários especialistas para criticar a Embrafilme. Matérias e editoriais com esse perfil - adotado pelo jornal O Estado de S. Paulo - também se repetiram no Globo, o que provocou um clima de desconfiança e incerteza em relação aos propósitos da Confecom. Intencionalmente, os representantes da grande mídia quiseram "assustar" a sociedade e alertar que estaria em curso

\footnotetext{
${ }^{141}$ Conferência quer intervir na mídia, O Estado de S. Paulo, 2009, 29/11/2009, p. 6.

${ }^{142}$ Conferência quer intervir na mídia, O Estado de S. Paulo, 29/11/2009, p. 6.
} 
mudanças que poderiam restringir as liberdades do cidadão, enquanto o objetivo da Confecom era exatamente criar mecanismos que pudessem garantir não apenas a liberdade de expressão e de imprensa, mas da própria sociedade, para que esta pudesse ter acesso aos meios de comunicação e que o pluralismo pudesse ser assegurado.

A postura adotada pelo jornal $O$ Estado de S. Paulo durante a Confecom, é coerente com a sua história e com a forma, como ao longo de sua existência, este jornal se relacionou com a elite dominante do país. Mesmo quando o Poder Executivo - como nos últimos doze anos - não está sendo ocupado pelo partido com que o jornal se identifica, as elites pouco mudaram. Com relação à Confecom, como foi exposto, O Estado de S. Paulo posicionou-se de forma contrária às propostas que seriam discutidas. Apoiou a saída das seis entidades patronais que se recusaram a participar das conversações e publicou um editorial e um artigo nos dias que antecederam a Conferência, criticando o evento e alegando que os temas propostos eram um atentado contra a liberdade de imprensa e os preceitos constitucionais da livre iniciativa.

Ao final do encontro o jornal $O$ Estado de S. Paulo, em editorial publicado no dia 21 de dezembro de 2009, intitulado "O saldo da Confecom"143, sugeriu, depois de desqualificar os participantes e criticar os resultados, que "o Governo agiria mais sensatamente se mandasse todas as proposições para a lata do lixo". Esta reação coaduna com trajetória do mesmo, que ao longo da sua história raras vezes ficou ao lado das bandeiras populares.

O jornal foi fundado em 4 de janeiro de 1875 é o mais antigo em circulação no estado. Inicialmente chamado de A Província de São Paulo, tinha em seus quadros ex-alunos da Academia de Direito. 'Registre-se a presença dos 'aprendizes do poder', todos egressos da faculdade de Direito e com envolvimento com a literatura" (MARTINS; De LUCA, 2011, p. 61). Foi criado com base nos ideais republicanos e sempre pertenceu à família Mesquita, todavia, desde 2003, a maior parte da família afastou-se da direção. Naquele ano, o Grupo Estado passou por uma grande reestruturação. O jornal reformulou sua gráfica em outubro de 2004 e criou novos cadernos, com um perfil mais moderno.

Sua linha editorial se coaduna com os interesses de grandes proprietários de terra e com a elite empresarial paulista. Defende a doutrina liberal, a iniciativa privada e critica os excessos da ampliação do Estado. Como todos os grandes jornais brasileiros, $O$ Estado de $S$. Paulo apoiou o Golpe Militar de 1964, pelo menos no seu início (MARTINS; De LUCA, 2011, p. 182).

\footnotetext{
${ }^{143}$ O saldo da Confecom, editorial, $O$ Globo, 21/12/2009, p. 5.
} 
O Estado de S. Paulo publicou dois editoriais no mês de março de 1964, criticando o governo de João Goulart e quase que pedia uma intervenção militar no País. Comparou o grande comício feito pelo presidente, onde este anunciou as reformas de base que iria implementar, denominado Comício da Central, com a Marcha da Família com Deus pela Liberdade.

$\mathrm{O}$ artigo do historiador André de Faria Pereira Neto, "o elitismo parece integrar o cardápio eclético do pensamento liberal presente nos editoriais de O Estado de S. Paulo" (PEREIRA NETO, 1999, p. 118). Em abril, já com o Golpe consolidado, o jornal publica outro editorial com apoio à intervenção militar, conforme o relato de Pereira Neto:

Nesta conjuntura de excepcionalidade constitucional, a posição política do
'Estadão', expressa no editorial do dia 19 de abril, demonstra por um lado
sua permanente autonomia política em relação a partidos políticos e, por
outro lado, revela a permeabilidade de seu discurso liberal. Se aquele
momento foi caracterizado por iniciativas contestáveis do ponto de vista
jurídico, isso para o Estadão pouco importava. O periódico abandona o
primado liberal da soberania das leis, propõe o abandono da legalidade
formal e sugere mais energia ao General-Presidente recém-empossado
(PEREIRA NETO, 1999, p. 120).

Nos primeiros anos do Golpe, ainda havia alguma expectativa com a possibilidade de os militares devolverem o poder para os civis e convocarem eleições para todos os níveis. Mas depois da saída do general Castelo Branco e a posse do general Costa e Silva, essa expectativa foi desaparecendo ao mesmo tempo que as liberdades civis foram reduzidas. $\mathrm{O}$ acirramento da censura nas redações, às vezes de forma truculenta, especialmente a partir de 1968, foi reduzindo a adesão dos jornais ao Golpe, e a censura prévia foi institucionalizada, conforme Martins e de Luca:

Com a proclamação em 13 de dezembro de 1968 do Ato Institucional $\mathrm{n}^{\circ}$ 5, que fechou o Congresso, suspendeu as garantias constitucionais e, entre outras coisas, foi usado para legalizar a censura prévia, o regime passou a exercer de forma mais direta a atividade censória sobre a imprensa e a mídia. Censores foram instalados nas redações dos jornais, circulares eram enviadas às redações dizendo o que se podia dizer e o que não se podia, vetando assuntos, nomes de pessoas - como Brizola e Arraes - e palavras como "comunismo" e "tortura", entre outras (MARTINS; De LUCA, 2011, p. 238).

O jornal O Estado de S. Paulo que sofreu essa intensa censura, "com o passar do tempo passou a se opor a ela que era, para dizer o mínimo, incômoda" (MARTINS; De LUCA, 2011, p. 238). Daí criou-se o hábito, por exemplo, de substituir as notícias vetadas por 
versos do poeta português Luiz Vaz de Camões ou, até mesmo, por receitas culinárias. Como estas não eram censuradas, os leitores começaram a perceber que havia censura nas matérias daqueles espaços e que isso era uma estratégia de resistência desenvolvida pelo jornal. Essa postura tornou a censura visível mundialmente e, em 1974, em pleno regime autoritário, o jornal recebeu o Prêmio Pena de Ouro da Liberdade, conferido pela Federação Internacional de Editores de Jornais.

Além disso, o jornal mostrou atitude corajosa no dia da edição do AI-5. Em 13 de dezembro de 1968, sua edição foi apreendida em razão da recusa de Mesquita Filho de excluir da seção Notas e Informações o editorial "Instituições em Frangalhos", no qual denunciava o fim de qualquer aparência de normalidade democrática.

Mais tarde, em 1984, não entrou na campanha pelas "Diretas Já", que pediam o fim do regime militar e, atualmente, não esconde sua oposição ao governo do Partido dos Trabalhadores. Nas eleições de 2002, que levaram o PT ao poder, o jornal não escondeu seu apoio ao adversário de Lula. Em 2010, na eleição da presidente Dilma Rousseff, publicou um editorial intitulado "O mal a evitar", no qual declara-se a favor do então candidato do PSDB, José Serra.

$O$ Estado de S. Paulo é um jornal de circulação nacional e atualmente, segundo o Instituto de Veiculação de Circulação (IVC), tem uma média de 240 mil edições diárias.

\subsubsection{O jornal Folha de S. Paulo diante da Confecom}

A Folha de S. Paulo adotou uma postura diante da Conferência Nacional de Comunicação que chamou a atenção pela sua indiferença. O que causa estranheza, pois é o único que dá um espaço expressivo para o leitor e tem em seus quadros, como já foi dito, a figura do ombudsman. A Folha, além de ter dado o menor número de matérias sobre a Confecom, não fez nenhum editorial sobre o tema, ao contrário dos outros dois. Foram recolhidos para o corpus tudo o que foi publicado sobre a Conferência no período analisado: 14 produtos, sendo nove matérias pontuais sobre a evolução da Confecom, quatro notinhas no Painel e apenas um artigo. Todo este material consta do Anexo I.

No dia da abertura dos trabalhos da Conferência, a Folha trouxe duas matérias e uma notinha na pág. A9, e nenhuma chamada na primeira página. Em matéria assinada por Elvira Lobato, que esteve na cobertura em Brasília, a jornalista afirma que o então presidente Lula, que abriria o evento no final do dia, iria pedir "mais transparência nas concessões de rádio e 
televisão, a proibição de políticos possuírem emissoras e a limitação do avanço das igrejas na mídia". ${ }^{144}$

Parece ser este o temário da própria Folha, pois o presidente na abertura do evento sequer tocou nestes assuntos, e os temas citados foram tratados pelos Grupos de trabalho ao longo do encontro e nem todas redundaram em propostas concretas, embora tenham sido discutidas. A matéria, além de ser bastante genérica ao comentar que os delegados irão discutir 1.400 propostas durante os quatros dias de reunião, colocou dúvidas sobre a legitimidade dos empresários participantes:

A representação do empresariado na conferência está prejudicada pela ausência dos grandes meios de comunicação - 6 das 8 entidades representantes das empresas do setor deixaram o evento. Restaram a Bandeirantes, a Rede TV e as empresas de telefonia. ${ }^{145}$

Todavia, a matéria não explica que estas entidades é que escolheram se ausentar do debate, apesar de terem sido convidadas para participar de todo o processo, desde as conferências estaduais. Os sites, por sua vez, ao comentar o mesmo episódio alegam que as associações de empresários saíram da Conferência na expectativa que ela não acorresse. A ideia, segundo o FNDC, era sabotar o evento.

Par a Folha as mais importantes emissoras de radiodifusão não participaram porque várias propostas contrárias às empresas de radiodifusão, como o controle social da mídia poderiam ser discutidas. E mesmo que fossem aprovadas elas não teriam caráter impositivo. No intuito de tranquilizar os seus pares, a Folha encerra a matéria lembrando que a Confecom "não tem poder para impor mudanças, mas apenas recomendá-las". ${ }^{146}$

Na mesma página, em uma matéria sem assinatura, a Folha afirma no título que “"Tribunal de mídia' está entre as propostas de evento”. Neste texto, de apenas, 22 linhas, o jornal escolheu as propostas mais radicais para criticar, dando ênfase para a que propunha que, "em 15 anos, 30\%das emissoras de rádio e TV, estariam nas mãos de entidades não comerciais", o que não foi aprovado. Mas a condução das matérias acabou criando um clima desfavorável ao evento por parte dos leitores.

Para comentar os temas, como o controle social, a Folha ouviu um dos representantes da ANJ (Associação Nacional dos Jornais) - uma das entidades que abandonou a Confecom Paulo Tonet. Segundo ele, “o controle social da mídia já existe: é controle remoto e o jornal

\footnotetext{
${ }^{144}$ Confecom pede transparência em concessões. Folha de S. Paulo, 14/12/2009, p. A9.

${ }^{145}$ Confecom pede transparência em concessões. Folha de S. Paulo, 14/12/2009, p. A9.

${ }^{146}$ Confecom pede transparência em concessões. Folha de S. Paulo, 14/12/2009, p. A9.
} 
na banca. Fora disso é censura e isso eu não quero mais”. Este é o mesmo argumento que foi dado, há cerca de vinte anos, por empresários que foram ouvidos pela Subcomissão de Comunicação criada para os trabalhos da Assembleia Nacional Constituinte, como já foi contado aqui no capítulo da contextualização. Este exemplo ilustra um dos resultados encontrados pela pesquisa, de que os empresários usaram o palco da Confecom para reafirmar suas posições, reiterar suas posturas contra qualquer tipo de fiscalização e acompanhamento do trabalho da mídia, sob o argumento de que o mecanismo de controle social é, na realidade, um tipo de censura prévia a ser imposto aos jornais.

No dia seguinte ao da abertura da Confecom, 15 de dezembro de 2009, o assunto também não vai para a primeira página, mas ganha destaque na página A11 da Folha de $S$. Paulo. No canto superior direito, em caixa alta e em três colunas com foto, o jornal registra: "Lula diz que defende imprensa livre, mas condena "excessos"”. Na abertura da Conferência, o então presidente Lula, diz que "tem compromisso sagrado com liberdade de imprensa, mas criticou excessos cometidos por jornais, rádios e TVs". ${ }^{147}$

Em seu discurso de abertura, Lula destaca:

tenho orgulho de dizer que a imprensa no Brasil é livre. Ela apura e deixa de apurar o que quer... Publica e deixa de publicar o que deseja... Mas essa mesma imprensa também se excede, despreza os fatos e embarca em campanhas, divulga inverdades ou mesmo calúnias e infâmias", mas finaliza dizendo que "aprendeu a conviver tranquilamente com isso, e que mais cedo ou mais tarde a verdade prevalece. ${ }^{148}$

A Folha de S. Paulo, porém, vai ao passado e busca um exemplo de intolerância do ex-presidente Lula para dizer que "a convivência de Lula com a imprensa nem sempre foi tranquila". Ou seja, a estratégia do jornal foi a de enfraquecer os argumentos expostos com relação ao que estava sendo discutindo, e colocando em dúvida a afirmativa do então presidente Lula, sugerindo que ele estaria sofismando com relação à liberdade da imprensa.

No primeiro mandato, ele ameaçou expulsar do país o correspondente do jornal americano The New York Times, em razão de uma reportagem sobre sua relação com o álcool. No segundo mandato, disse que não lê jornal para não ficar com azia. ${ }^{149}$

\footnotetext{
${ }^{147}$ Lula diz que defende imprensa livre, mas condena "excessos". Folha de S. Paulo, 15/12/2009, p. A11.

${ }^{148}$ Lula diz que defende imprensa livre, mas condena "excessos". Folha de S. Paulo, 15/12/2009, p. A11.

${ }^{149}$ Lula diz que defende imprensa livre, mas condena "excessos". Folha de S. Paulo, 15/12/2009, p. A11.
} 
Na mesma matéria, a Folha comenta que a Confecom chegou a ser ameaçada por uma polêmica ${ }^{150}$ com empresários do setor sobre o regimento do encontro. O jornal conta que o "Governo se aliou às empresas para impedir a debandada da Rede Bandeirantes e da Rede TV!" e que os movimentos sociais haviam tentado mudar as regras do quórum qualificado na manhã daquele dia. Ao final, o jornal enfatiza que na pauta da Confecom estão propostas que afetam as empresas de comunicação, como o controle social da mídia, aumento de potência das rádios comunitárias e a proibição da propriedade cruzada de meios de comunicação.

A Folha de S. Paulo, apesar de ter sido o jornal que concedeu menos espaço ao evento, foi o que melhor conseguiu perceber o crescimento da representatividade das empresas de telecomunicações. Com a desistência da maioria das associações que representam empresas privadas de mídia, a companhias telefônicas aumentaram o seu número de delegados, fizeram muito barulho e acabaram ganhando aliados junto aos representantes das entidades sociais.

No dia 16 de dezembro de 2009, a Folha publicou uma matéria intitulada "Teles têm maior poder de voto em conferência de comunicação" onde destaca o crescimento das teles no evento.

As companhias telefônicas aproveitaram o esvaziamento da $1^{a}$ Conferência Nacional de Comunicação, convocada pelo presidente Lula e iniciada anteontem, para colher dividendos políticos, tanto no governo como no meio sindical. Eles enviaram 418 funcionários para o encontro, em Brasília, para assegurar que a cota de 632 delegados destinada ao setor empresarial fosse ocupada. Com isso, a telefonia tornou-se o segmento com maior representação na conferência, com $26 \%$ do total de delegados com poder de voto. $^{151}$

Como a representação empresarial ficou esvaziada, as teles acabaram tendo mais espaço e mais diálogo com os sindicatos e representantes das entidades do movimento social, e estes, por sua vez, perderam de vista o adversário histórico cristalizado pela Abert, (Associação Brasileiras das Emissoras de Rádio e TV), que representa a Globo, e em muitas decisões votaram junto com as teles. Segundo a representante da CUT (Central Única dos Trabalhadores), Rosane Bertotti, em entrevista à Folha, "os sindicatos vão concentrar esforços nas propostas de universalização da banda larga, na aprovação de um marco regulatório que proíba políticos de receberem concessões de rádio e TV e no controle social da mídia" ${ }^{, 152}$. Neste quesito, as entidades defendem as mesmas propostas dos empresários.

\footnotetext{
${ }^{150} \mathrm{O}$ assunto foi tratado no capítulo específico da Confecom.

${ }^{151}$ Teles têm maior poder de voto em conferência de comunicação. Folha de S. Paulo, 16/12/2009, p. A9.

${ }^{152}$ Teles têm maior poder de voto em conferência de comunicação. Folha de S. Paulo, 16/12/2009, p. A9.
} 
No começo dos trabalhos da Conferência, os representantes das empresas de telecomunicações ganharam a simpatia dos delegados ligados aos sindicatos, associações e ONGs por estarem presentes na Confecom, e por demonstrarem que eles não iriam se alinhar automaticamente com as propostas defendidas pelos empresários tradicionais. A Folha de S. Paulo, por sua vez, aproveitou o entusiasmo do público para criticar os movimentos da sociedade civil: "ontem, no primeiro dia de trabalho, as teles, campeãs de reclamações de consumidores, foram chamadas de "empresariado progressista" por oradores do movimento sindical.,"153

No dia 18 de dezembro de 2009, quando a Folha trouxe a matéria sobre as decisões finais da Confecom, ela destacou a rejeição dos sindicatos à redução de impostos sobre a banda larga.

Embora o Brasil tenha uma das maiores cargas tributárias sobre serviços de telecomunicações no mundo (43\% em média) a proposta foi rejeitada por representantes de sindicatos, ONGs e associações de rádios comunitárias, porque a diminuição de impostos foi vista pela entidades para que as empresas embolsassem mais dinheiro. ${ }^{154}$

Este tipo de postura adotada pelos movimentos sociais, naturalmente, contraria a vontade da sociedade brasileira, que tem uma das maiores cargas tributárias do mundo. E ainda queriam criar um imposto novo sobre a venda de televisores para criar um fundo de reserva para o segmento da mídia pública. Que tipo de adesão e empatias as entidades civis não empresariais esperaram obter da sociedade depois de posições como essas?

Dentre as propostas já aprovadas no penúltimo dia da Conferência, a Folha, em matéria de cem linhas, que ocupou as cinco colunas da pág. A13, deu destaque a duas, a que pretende evitar emissoras para políticos e a que sugere a criação do Conselho Federal de Jornalismo e dos conselhos estaduais, patrocinada pela Fenaj (Federação Nacional dos Jornalistas). A Folha conta que a proposta que quer proibir emissoras para políticos foi aprovada por consenso, isto é, nenhum dos lados pediu "questão sensível” e o apoio à decisão veio de todos os lados, porém, logo a frente, a Folha reitera: "a Conferência não tem poder de impor mudanças, só de recomendá-las”. Um modo de apoiar os possíveis atingidos pela medida. Em praticamente, todas as matérias, a Folha foi enfática ao repetir este ponto para realçar o aspecto apenas propositivo da Confecom.

\footnotetext{
${ }^{153}$ Teles têm maior poder de voto em conferência de comunicação. Folha de S. Paulo, 16/12/2009, p. A9.

${ }^{154}$ Sindicatos rejeitam redução de imposto sobre banda larga. Folha de S. Paulo, 18/12/2009, p. A13.
} 
Na mesma matéria a Folha foi ouvir os políticos donos de emissoras, e eles trataram de desqualificar a proposta. Para o então senador do DEM/BA, Antônio Carlos Magalhães Júnior "trata-se de uma hipocrisia". Sua família possui seis emissoras geradoras de televisão e três rádios na Bahia. "Seria inócuo, disse ele, porque os políticos que já têm emissoras não irão se desfazer delas e, muito provavelmente, passariam as concessões a um laranja para se enquadrar na lei". 155

Segundo dados da Folha de S. Paulo, 2009, "calcula-se que havia no Brasil, pelo menos 271 políticos na condição de sócio ou diretores de 348 emissoras de rádio e de TV. Entre os chamados políticos-radiodifusores destaca-se o ex-presidente e atual senador Fernando Collor de Melo, o então senador e hoje ministro das Minas e Energia, Edson Lobão, os senadores Wellington Salgado (PMDB/MG), Renan Calheiros (PMDB/AL) e também Jáder Barbalho (PMDB/PA) e Albano Franco (PSDB/SE).

Na mesma matéria a Folha comenta a proposta de criação do Conselho de Jornalismo, diz que ela é polêmica, mas foi aprovada por consenso. O jornal fez menção ao Conselho Federal de Jornalismo proposto em 2004, e reiterou que "à época o projeto provocou forte reação porque foi entendido como ameaça à liberdade de imprensa". Mais uma vez, a Folha reafirma o mesmo discurso de 1988 e de 2004, de que qualquer mecanismo que tente criar uma forma de acompanhar ou fiscalizar o trabalho da imprensa é propositalmente confundido com censura. Ou seja, o jornal repete a mesma postura, embora saiba que não se fala em censura de conteúdo. A Confecom acabou propiciando que os jornais atualizassem suas críticas e seus receios com relação a qualquer tipo de regulamentação.

Dois dias após o encerramento da Confecom, a Folha publicou uma matéria longa para ressaltar que nada de importante que foi aprovado no encontro tem o poder de atingir a mídia. Segundo a Folha (2009), “vice-presidente da Bandeirantes, Walter Vieira Ceneviva - o mesmo que na época da Constituinte defendia o controle sobre a mídia - afirmou que as propostas que parecem de controle são inócuas" ${ }^{\text {156. }}$. Para ele, as propostas que estão sendo apontadas como ameaça são inócuas ou foram mal redigidas, o que geram interpretações erradas. Ceneviva (2009) avaliou que o saldo do encontro foi positivo e discorda que tenha sido aprovada qualquer medida contra a mídia. "Houve uma tentativa de garrotear a imprensa, mas ela foi derrotada", assinalou.

O vice-presidente da Band minimizou a proposta que cria o Conselho de Comunicação e disse que

\footnotetext{
${ }^{155}$ Confecom quer vetar emissora para políticos. Folha de S. Paulo, 17/12/2009, p. A13.

${ }^{156}$ Confecom não atinge a mídia, afirmam empresa e ministério. Folha de S. Paulo, 19/12/2009, p. A13.
} 
o que está sendo interpretado como um tribunal da imprensa refere-se à criação de um observatório da mídia para acompanhar as programações e denunciar violações aos direitos humanos. Isso já existe. O portal Observatório da Imprensa já exerce essa função. Não vejo ameaça nisso. ${ }^{157}$

As medidas que Ceneviva (2009) apontou que pretendiam "garrotear" a imprensa se referem a algumas pertencentes ao Grupo de Trabalho 11 (que tratou de Cidadania: direitos e deveres: democratização da Comunicação, participação social na Comunicação). Algumas delas, previam a cassação de concessões de emissoras de rádio e televisão que criminalizassem movimentos sindicais e sem-terra nos noticiários; redistribuição das concessões existentes; auditoria imediata em todas as emissoras de TV; a criação de um conselho gestor para decidir sobre a qualidade da programação das televisões; além do estabelecimento de limites à distribuição de concessões.

O advogado Walter Ceneviva, que hoje representa a Abra, e executivo do Grupo Bandeirantes ocupava um outro lugar de fala durante os debates da Assembleia Nacional Constituinte. Na ocasião, então com 54 anos, foi ouvido para opinar sobre a legislação da radiodifusão em vigor. Ceneviva (2009) foi um dos raros atores que esteve presente nestes dois momentos, o da Constituinte e o da Confecom, porém, em posições opostas. Ainda antes da convocação da ANC, pelo então presidente José Sarney, Ceneviva defendeu, em entrevista ao jornal Folha de S. Paulo,

a necessidade de que a concessão de rádio e televisão seja tratada em lei com
um enfoque doutrinário próprio, dada a sua especificidade, uma vez que a
legislação atual (o Código Brasileiro de Telecomunicações de 1962) é
omissa, confusa e desatualizada e que ela não protege o cidadão do controle
governamental e nem dos abusos do poder econômico privado. ${ }^{158}$

Ceneviva chegou a falar até em "controle social" à Folha de S. Paulo. "As mudanças sugeridas pelo jurista preservam o caráter público dos serviços de radiodifusão, mas indicam no sentido de que o controle estatal seja substituído pelo controle social” (MOTTER, 1994, p. 113). Ainda na Folha de S. Paulo, Ceneviva chega a reconhecer o direito à informação, ainda um conceito recente na ocasião. "O direito de todo corpo social de receber informações compatíveis com a natureza do rádio e da televisão enquanto serviço público é maior e mais importante do que o direito privado de exploração desses mesmos serviços públicos”.

\footnotetext{
${ }^{157}$ Confecom não atinge a mídia, afirmam empresa e ministério. Folha de S. Paulo, 19/12/2009, p. A13.

158“Leis de radiodifusão contrariam a sociedade", Folha de S. Paulo, 28/10/84, p. A9.
} 
Em 2009, este mesmo Ceneviva, no encerramento da Confecom, afirmou, também em entrevista à Folha de S. Paulo ${ }^{159}$ que "as propostas aprovadas na Confecom, como a criação de um conselho de jornalismo é inócua, e que houve uma tentativa de importante e organizada de garrotear a imprensa, mas foi derrotada". E acrescentou ainda, "existiam dezenas de propostas na agenda da conferência que ameaçavam a imprensa e que foram vetadas, como a redistribuição das concessões existentes; a auditoria imediata em todas as emissoras e a criação de um conselho gestor para decidir sobre a qualidade da programação midiática e o estabelecimento de limites à concessão". É que Ceneviva, desde 2007, assumiu a vicepresidência executiva do grupo Bandeirantes e na Conferência também atuou como representante da Abra (Associação Brasileira de Radiodifusores). O seu lugar de fala mudou diametralmente, o que explica o discurso manifesto na Confecom.

No dia 21 de dezembro de 2009, a Folha, praticamente, não tocou mais no assunto Confecom, a não ser por uma notinha maliciosa no Painel atribuída ao então deputado federal Eduardo Gomes (PSDB/TO). No intuito de desqualificar a proposta da criação dos conselhos ou de observatórios de mídia A Folha publicou: "Em vez de cuidar da TV Brasil, desde sempre traço de audiência, o Planalto realizou a Confecom para tentar controlar a mídia"160. E finalmente, no dia 27 de dezembro de 2009, a Folha, que sempre traz neste dia a página do Ombudsman, optou por ignorar o tema e publicou apenas um artigo do bispo Dimas Lara Barbosa, então secretário-geral da CNBB (Conferência Nacional dos Bispos do Brasil) onde este reconhece a importância da Conferência, embora ela não tenha atendido aos anseios da igreja.

O Brasil acabou de realizar sua primeira Conferência Nacional de Comunicação. Um marco na história do país e um avanço que não pode parar, se quisermos realmente democratizar a comunicação. A CNBB participou como observadora e testemunhou a lição de democracia dada pela conferência, quando atores tão diversos - o poder público, empresários e movimentos sociais - foram capazes de se sentar e dialogar sobre tema tão complexo e exigente. ${ }^{161}$

Para o bispo, a evocação à laicidade do Estado foi interpretada com um equívoco, pois esse aspecto acabou por impedir - pela ação de uma minoria - que "se outorgassem concessões de rádio e TV às igrejas”. O que para ele foi uma contradição ao que se propunha a Conferência, "que era de dar a todos o direito e o acesso à comunicação", lamentou.

\footnotetext{
${ }^{159}$ “Confecom não atinge a mídia, afirmam empresa e ministério", Folha de S. Paulo, 19/12/09, p. A11.

${ }^{160}$ Painel, Folha de S. Paulo, 19/12/2009, p. A4.

${ }^{161}$ Igreja e Estado Laico, Dimas Lara Barbosa. Folha de S. Paulo, 27/12/2009, p. A3.
} 
O jornal Folha de S. Paulo, ao longo da sua história (é o mais jovem dos três jornais estudados) já adotou posturas que denunciaram uma certa contradição do seu perfil ideológico, como quando apoiou os militares durante o Golpe de 64 e depois foi intransigente defensor do fim da ditadura. E a sua postura diante da Confecom desvelou um pouco deste perfil dúbio. Apesar de construir um discurso que busca uma aproximação com os pleitos dos seus leitores mais associados à vanguarda, o jornal não se mostrou muito preocupado em adotar uma posição na Conferência que apoiasse a participação popular e defendesse que os leitores tivessem uma participação de protagonismo na mídia tradicional.

O jornal Folha de S. Paulo foi fundado em 19 de fevereiro de 1921, por um grupo de jornalistas liderado por Olival Costa e Pedro Cunha, com o nome de Folha da Noite. Desde agosto de 1962 pertence à família de Octávio Frias. É um jornal que ganhou muito espaço junto à classe média, aos intelectuais e acadêmicos por manter uma postura mais liberal em assuntos de vanguarda como o direito das mulheres, a questão ambiental e outros, mas na Confecom se comportou como a mídia mais tradicional do país.

A Folha vende uma imagem de jornal plural, aberto e que dá espaço para todas as facções. Foi o primeiro jornal brasileiro a criar, em 1989, a figura do ombudsman, uma espécie de ouvidor que tem como missão receber as críticas dos leitores, responder e fazer comentários críticos sobre o próprio jornal. É um jornal que privilegia o espaço do leitor.

Apesar de ter sido o jornal que primeiro encampou a luta pela volta das eleições diretas e à normalidade democrática, em 1984, no passado também apoiou o Golpe Militar de 1964, como os demais empresários do setor. No dia 3 de abril de 1964, publicou um editorial intitulado Forças Armadas, no qual afirmava que a intervenção dos militares teria sido apenas para superar uma crise no Exército.

Tanto a Folha como O Estado de S. Paulo publicaram editoriais criticando o comício do então presidente João Goulart, afirmando que defendiam a ordem e que o comício havia sido organizado por extremistas que tentavam subverter essa ordem. ${ }^{162}$ Em outro editorial, no dia 14 de março de 1964, intitulado O presidente fora da lei, A Folha publica em tom provocativo: "Resta saber se as Forças Armadas (...) preferirão ficar com o Sr. João Goulart, traindo a Constituição, a pátria e as instituições".

Anos depois, na década de 1970, segundo o escritor Expedito Leal Ribeiro, "a teria cedido seus veículos às forças policiais e militares, para o trabalho de perseguição às

\footnotetext{
${ }^{162}$ Esta informação está disponível em: <www.folhadesaopaulo.com.br>. Acesso em: 8 fev. 2014.
} 
lideranças estudantis, sindicais e políticas...” (RIBEIRO, 2007). Jornais alternativos, como o Movimento, chegaram a noticiar que esses veículos eram usados por policiais não identificados que agiam a serviço do Exército. Depois dessas afirmações, o jornal foi perseguido e o proprietário Octávio Frias ameaçado de morte, segundo depoimento de Gaspari (2002, p. 395).

Octávio Frias de Oliveira para se defender, assinou um editorial intitulado Banditismo $^{163}$, afirmando que não aceitaria agressão nem ameaças. Em junho de 1972, mais por conflitos entre o jornal e grupos de esquerda do que por convicção, o jornal publicou outro editorial, denominado "Presos Políticos?", no qual questionava se havia, de fato, pessoas presas por causa de suas posições políticas. A partir desse momento, os editoriais foram suspensos.

As boas relações com a esquerda e os movimentos sociais só seriam retomados a partir de 1984, quando a Folha encampou a luta pela volta das eleições diretas em todos os níveis. Esse fato é reconhecidamente aceito por entidades ligadas a movimentos sociais e associações que lutaram pela redemocratização do País. Para o historiador americano Thomas Skidmore, a Folha deu uma importante contribuição ao movimento, conforme o texto a seguir:

Outras adesões foram surgindo, como a das associações de advogados e dos principais jornais como a Folha de S. Paulo. Importante contribuição também foi dada pelos artistas e personalidades do show business que ajudaram a transformar os comícios em grandes happenings culturais (SKIDMORE apud MENDEZ, 1988, p. 468).

Ainda segundo Mendez (1988), "a campanha pelas eleições diretas foi ocupando cada vez mais espaço na mídia, ganhando força própria e tornando-se caudalosa por diversas adesões, entre elas, a de grandes jornais, começando pela Folha de S. Paulo" (MENDEZ, 2009, p. 467). ${ }^{164}$

A escritora Carolina Matos, em relação ao cenário em que se consolidou a mídia brasileira nos últimos 30 anos, também corrobora essa tese quando afirma:

O jornal Folha de S. Paulo emergiu como o primeiro grande diário a explicitamente levantar a bandeira a favor das eleições diretas, assumindo uma posição militante e ativa destacada na época em relação a outros jornais, principalmente devido às críticas ao establishment militar (MATOS, 2008, p. 50).

\footnotetext{
163 Otavio Frias de Oliveira. Editorial: Banditismo - publicado em 22 de setembro de 1971.

${ }^{164}$ Disponível em: <www.intercom.org.br/papers/nacionais/2009/resumos/R4-1393-1.pdf>.
} 
Para a escritora, endossar as diretas significava refletir o desejo de milhões de brasileiros, que queriam a volta da democracia, depois dos "anos de chumbo", das torturas e do autoritarismo dos militares. "A Folha viu no apoio uma oportunidade para se capitalizar jornalisticamente" (MATOS, 2008, p. 51). Essa tomada de posição veio de encontro à linha de aparente neutralidade e até "passividade" em relação às posturas que a Folha havia adotado na década passada, quando da edição o Ato Institucional $\mathrm{n}^{\circ}$ 5. A partir do momento que a Folha abandona essa postura conquista o posto de jornal político mais influente do País.

"Neste contexto, a cobertura das Diretas-Já, pela Folha, marcou o pico de seu engajamento com o jornalismo militante político. Com isso, conseguiu criar meios para consolidar sua posição como o diário político mais influente do país” (MATOS, 2008, p. 51). Na mesma publicação, Matos destaca:

há bastante controvérsia com relação às contribuições realizadas pela Folha de S. Paulo. Críticos radicais (CARTA, 1998; ARBEX JUNIOR, 2001; KUCINSKI, 1998) sugeriram que a cobertura da Folha foi pura estratégia de marketing, "um projeto democrático para o mercado" (MATOS, 2008, p. $53)$.

No entanto, a autora considera que essa opinião é parcialmente verdadeira e que a questão é mais complexa. Depois desse período, "a Folha deixou de lado o jornalismo mais opinativo para atender às demandas de mercado, consolidando-se dentro do modelo de jornalismo comercial norte-americano" (MATOS, 2008, p. 53). Esse novo jornal acabou por atrair públicos mais amplos e variados, indo além dos representantes da sociedade civil organizada e das elites intelectuais e empresariais.

É um jornal de circulação nacional e, segundo o Instituto de Veiculação de Circulação (IVC), lidera o ranking, com uma média de 300 mil edições diárias.

\subsubsection{O jornal $O$ Globo diante da Confecom}

No começo de novembro de 2009, o jornal O Globo começou a publicar matérias sobre as mudanças que estavam ocorrendo na Argentina e destacou as ameaças que a liberdade de imprensa estava sofrendo em toda a América Latina, mas não citou a realização da Confecom, que iria ocorrer no mês seguinte. O assunto só foi citado no último parágrafo de uma matéria interna cujo assunto principal era a insatisfação da Abert e da ANJ sobre a 
liberdade "excessiva" dos portais de notícias da internet ${ }^{165}$. Essa matéria trouxe as queixas dos empresários da mídia tradicional sobre os possíveis privilégios dos sites de notícias.

"Que os portais da internet, que fazem papel de empresas de comunicação, sejam submetidos às mesmas regras válidas para jornais, revistas, rádios e emissoras de TVs"166, exigiam os empresários. Essa matéria, bastante curiosa e contraditória, conta sobre uma reunião ocorrida na Comissão de Ciência, Tecnologia, Comunicação e Informática da Câmara dos Deputados, na qual os representantes da Abert, ANJ e Abranet defenderam com veemência as mesmas regras para os jornais ${ }^{167}$. Essa reclamação se refere apenas ao limite máximo de $30 \%$ de participação do capital estrangeiro nessas empresas. Todos recorreram à Constituição Federal exigindo que todas as empresas se submetam à Constituição. Ela chamou atenção porque sugere que as empresas jornalísticas gostariam que - neste quesito houvesse algum tipo de regulação por parte do Estado, um mecanismo que essas empresas rejeitam quando se trata de questões relativas à qualquer regulação da mídia.

A alegação é que esses portais ignoram a Constituição brasileira, em seu art. 222, e cobram a aplicação de regras para todos os veículos de comunicação, conforme prevê a Constituição. O contraditório é que eles ignoram o artigo que segue a este, o art. 223, que trata da proibição de monopólios e oligopólios na radiodifusão, pecado que a Abert, na qualidade de representante da TV Globo e de outras emissoras privadas, está incorrendo desde 1988, quando a Carta Magna foi promulgada.

Para enfatizar o apelo para que a lei seja cumprida, mas apenas no que convém às essas entidades que representam a mídia privada, a nota da Abert (divulgada após a citada reunião na Câmara dos Deputados) afirma que - supostamente - fala em nome da sociedade brasileira,

Está mais do que na hora de a sociedade brasileira restabelecer a lei e desfazer o equívoco: a liberdade irrestrita no uso da infraestrutura de redes da internet não pode ser confundida, com desrespeito à lei, no que se refere à produção e programação de conteúdo nacional. ${ }^{168}$

Ao final, os representantes da mídia tradicional se esforçam em diminuir a importância da internet e seu impacto na comunicação e ressaltam que a internet é "apenas um novo meio de se difundir conteúdos que, até poucos anos, eram distribuídos apenas por papel impresso e por rádio e TV", nota da ANJ e Abert, na qual cobram regras iguais para sites, publicada no

\footnotetext{
${ }^{165}$ Regras iguais para jornais e portais da internet, $\boldsymbol{O}$ Globo, 12/11/2009, p. 11.

${ }^{166}$ Regras iguais para jornais e portais da internet, $\boldsymbol{O}$ Globo, 12/11/2009, p. 11.

${ }^{167}$ ANJ e Abert cobram regras iguais para sites, O Globo, 12/11/2009, p. 9.

${ }^{168}$ ANJ e Abert cobram regras iguais para sites, O Globo, 12/11/2009, p. 9.
} 
jornal $O$ Globo em 2009. Esta reação dos empresários é uma forma velada de não admitirem que se sentem ameaçados pelo aparato trazido pela internet, a TV Globo, por exemplo, até o ano 2000 resistia a mudar seu modelo de negócio e admitir que nada mais seria como antes depois da web.

Somente no dia 19 de novembro de 2009 é que o jornal $O$ Globo comenta a realização da Confecom e o faz para noticiar a divulgação do documento que o Partido dos Trabalhadores (PT) aprovou para ser levado à Conferência, "PT defende controle público e sanções à imprensa" ${ }^{\text {169 }}$. Sem nenhuma chamada na primeira página sobre o assunto, o jornal afirma que o PT "defende o controle público dos meios de comunicação e a criação de mecanismos de sanção à imprensa”.

O jornal acrescenta que o documento aprovado pelo diretório nacional do PT, intitulado: "Resolução sobre a estratégia petista na Conferência Nacional de Comunicação", defende mudanças no modelo de outorga de concessões e que esse modelo é "anacrônico, autoritário e privilegia grupos comerciais em detrimento dos interesses da população". Para contrapor essas propostas, o jornal foi ouvir um professor especialista em comunicação, Carlos Alberto Di Franco ${ }^{170}$. Essa é uma estratégia usual da mídia, quando quer expor os pontos de vista que defende, sem fazer uso do editorial. O jornal busca um porta-voz que se apropria do ponto de vista do jornal. Neste caso, o Globo não foi em busca de uma opinião mais isenta, este professor não é apenas professor, ele faz parte do Comitê Editorial da ANJ (Associação Nacional dos Jornais), que é uma entidade e que reúne os proprietários de empresas de mídia, e além disso, Di Franco faz parte do Conar, que é um conselho de autorregulação de propaganda.

O professor Di Franco (2009) afirma que “as propostas do PT preocupam, pois podem esconder objetivos de controle ideológico como os que foram aplicados em outros países latino-americanos como a Venezuela e a Argentina".

Além disso, Di Franco (2009) faz um alerta: "sob o pretexto de democratização, o que se oculta é a tentativa de um crescente controle ideológico da informação... o que vemos é o crescimento de uma visão autoritária, centralizadora e antidemocrática". Para finalizar a matéria, o jornal lembra que o então presidente Lula, nos últimos meses, "não havia poupado

\footnotetext{
${ }^{169} \mathrm{PT}$ defende controle público e sanções à imprensa, $\boldsymbol{O}$ Globo, 19/11/2009, p. 15. Disponível em: <http://extra.globo.com/noticias/brasil/pt-defende-controle-publico-sancoes-imprensa-200179.html>.

${ }^{170}$ Carlos Alberto di Franco, professor da Universidade de Navarra, Espanha. O Globo, 19/11/2009, p. 15.
} 
ataques à imprensa e chegou a afirmar, em um encontro com catadores de material reciclável, que os formadores de opinião já não exercem influência sobre a população". ${ }^{171}$

Embora o tenha feito de forma enviesada, $O$ Globo quebrou o silêncio e passou a citar, tangencialmente, a realização da Confecom. Depois da matéria em que as propostas do PT para o encontro foram divulgadas, o jornal publica a voz da ANJ para alertar sobre os riscos da Conferência. ${ }^{172}$

A presidente da ANJ, Judith Brito ${ }^{173}$ disse que "preocupa toda iniciativa que signifique controle dos meios de comunicação" e lembrou, de forma enfática, "que a Constituição é categórica no sentido de que a liberdade de expressão deve ser exercida sem controles", ignorando que essa mesma Constituição proíbe a formação de monopólios no setor da radiodifusão. Além disso, alega Brito (2009), "para eventuais excessos cometidos pelos meios de comunicação e pelos jornalistas aplica-se a legislação geral sobre danos morais". Mais uma vez, a ANJ finge ignorar a realidade da morosidade da justiça brasileira, tão noticiada pela mídia.

Essa mesma matéria, contudo, no seu final, rebate a ameaça sugerida pela ANJ, ao ouvir uma das entidades que participou ativamente da Confecom, a Fenaj. O presidente da Federação Nacional dos Jornalistas (Fenaj), Sérgio Murilo de Andrade, em defesa do encontro, destacou que:

qualquer discussão sobre a necessidade de o sistema ser democratizado, logo vinculam à censura e ao controle do Estado... não há possibilidade de se repetirem, no Brasil, as mudanças na legislação feitas nos países vizinhos, como Venezuela e Argentina, para limitar a ação da imprensa. (ANDRADE, 2009).

Essa matéria evidencia, mais uma vez, a adoção da "estratégia da confusão" de conceitos, elaborada por Guareschi ${ }^{174}$ (2013), citada neste trabalho. No final de novembro, a 15 dias do início da Confecom, o jornal $O$ Globo fez uma longa reportagem sobre "o cerco à mídia independente na América Latina”, com matérias especiais sobre a Argentina, a Venezuela e o Equador. Sobre o Brasil, o jornal destacou a questão da censura judicial que estava sendo feita ao jornal $O$ Estado de S. Paulo e somente no meio da matéria ${ }^{175}$, que

\footnotetext{
${ }^{171}$ PT defende controle público e sanções à imprensa, $\boldsymbol{O}$ Globo, 19/11/2009, p. 15. Disponível em: <http://extra.globo.com/noticias/brasil/pt-defende-controle-publico-sancoes-imprensa-200179.html>.

${ }^{172}$ ANJ reage à proposta de controle da imprensa, $O$ Globo, 20/11/2009, p. 10.

${ }^{173}$ Presidente da Associação Nacional de Jornais, Judith Brito, 2009.

${ }^{174}$ Pedrinho Guareschi chamou de "estratégia de confusão" a postura adotada pela grande mídia de confundir, intencionalmente, a liberdade de expressão com a liberdade de imprensa.

${ }^{175}$ Censura prévia por ordem da justiça. Suplemento especial. O Globo, 29/11/2009, p. 44.
} 
ocupou três colunas e metade da parte superior da página, é que menciona a realização da Confecom, e o faz no sentido de deixar claro que o Brasil também pode sofrer o que os países vizinhos estavam sofrendo. "O receio agora é em relação ao resultado da Conferência Nacional de Comunicação... Pois o PT irá apresentar um projeto sobre o controle público dos meios de comunicação" ${ }^{\text {176 }}$, advertia a matéria.

Mais uma vez, $O$ Globo reforça a posição dos empresários da mídia tradicional: "para a ANJ não há necessidade de instrumentos de controle... E eventuais desvios podem ser resolvidos com a regulamentação do direito de resposta”. Depois desta matéria, o jornal optou pelo silêncio, nada mais foi noticiado sobre a Conferência até seis dias antes dela ter início. A postura do jornal, ao longo de todo processo de construção e realização da Confecom, só reforçou o perfil ideológico que mantém desde a sua fundação. Braço escrito do conglomerado do senhor Roberto Marinho, o jornal teve que cobrir o evento, mesmo sabendo que a TV Globo, por meio da Abert, se recusou a participar por ter se sentido ameaçada em seus interesses.

A cobertura foi guiada o tempo todo com a certeza de não dar espaço a qualquer proposta que pudesse por em risco o monopólio estabelecido. A hegemonia construída pelo império da TV Globo não admite, se quer que o tema seja discutido, e que este poderio possa ser ameaçado por novas legislações. A cobertura feita pelo jornal $O$ Globo foi conduzida para que, em qualquer matéria, por menor que fosse, a conferência fosse deslegitimada, pela ausência das demais entidades privadas que deixaram a Conferência em agosto de 2009. Além de buscar atribuir qualquer possível ideia de controle, fiscalização, criação de conselhos ou observatórios de mídia ao caráter autoritário do Partido dos Trabalhadores (PT), partido este que nunca teve o apoio do empresariado midiático.

O jornal $O$ Globo, de propriedade da família Marinho, foi fundado em 29 de julho de 1925 por Irineu Marinho, pai de Roberto Marinho, que criou a TV Globo. Porém, Irineu faleceu 21 dias após a fundação do jornal e quem assumiu a empresa não foi o filho, que lá trabalhava como repórter e era secretário particular do pai. O comando da empresa foi parar nas mãos do jornalista Euclydes de Matos, amigo de confiança de seu pai. Roberto Marinho somente assumiu o controle da empresa após a morte de Euclydes em 1931.

O jornal faz parte de um grande conglomerado de empresas de mídia, hoje reunidas na holding Organizações Globo. O grupo detém, além do jornal, a maior cadeia de TV do País e segunda maior do mundo. Possui também a Rádio Globo e a CBN, a Editora Globo, a Revista

\footnotetext{
${ }^{176}$ Censura prévia por ordem da justiça. Suplemento especial. O Globo, 29/11/2009, p. 44
} 
Época, o portal Globo.com. Até 2012 a Globo também possuía a maior parte das ações da TV a cabo NET.

Assim que foi fundado, o jornal começou a se posicionar diante de um movimento político importante da época - o movimento tenentista. Ao contrário do que acabou por marcar o perfil do jornal, de alinhamento automático ao poder instituído, o jornal se opôs ao governo de Arthur Bernardes, que tomou posse em 1922, apesar da resistência dos militares, e que governou até 1926. “O Globo não se opôs aos levantes militares que ocorreram em 1922 com a tomada do Forte de Copacabana, postura que lhe custou a suspensão de atividades entre agosto de 1924 e maio do ano seguinte" (MARTINS; De LUCA, 2011, p. 163).

Durante o governo de exceção de Getúlio, o jornal também sofreu perseguição e censura, pois cobrava do ditador uma constituinte que institucionalizasse a Revolução de 1930, como havia sido prometido. Em 1946, quando foi aprovada a nova Constituição, de caráter democrático, o jornal estava do lado do governo. Apesar de ter apoiado a intervenção militar em 1964, Roberto Marinho posicionava-se, sempre que possível, pela legalidade e respeito às instituições, e foi assim, alguns anos antes, em 1961, quando foi cogitada que a posse de João Goulart fosse impedida. Jango substituiria o presidente Jânio Quadros, que renunciara ao cargo em agosto daquele. Nesta ocasião, Marinho apanhou a campanha pela legalidade e João Goulart tomou posse. Todavia em 1964 como se sabe, Roberto Marinho apoiou a retirada de Jango do poder.

\subsubsection{O Globo e o Golpe de 1964}

Mais do que a Folha e $O$ Estado de S. Paulo, $O$ Globo nunca escondeu seu apoio ao Golpe Militar de 1964. Nos dias que antecederam o dia 31 de março de 1964, o jornal publicou um editorial conclamando as Forças Armadas a agir contra "a ameaça comunista". Embora os outros dois jornais também tivessem publicado editoriais no início do Golpe Militar apoiando a intervenção, $O$ Globo insistiu nesse apoio, mesmo com o fim da ditadura se aproximando.

No mesmo ano em que a insatisfação com o regime começava a ir para as ruas, 1984, o ano das Diretas-Já, Roberto Marinho publicava artigo lembrando que sempre esteve ao lado dos militares, desde o início: "Participamos da Revolução de 1964, identificados com os anseios nacionais de preservação das instituições democráticas, ameaçadas pela radicalização ideológica, greves, desordem social e corrupção generalizada. Quando a nossa redação foi invadida por tropas antirrevolucionárias, mantivemo-nos firmes em nossa posição. 
Prosseguimos apoiando o movimento vitorioso desde os primeiros momentos de correção de rumos até o atual processo de abertura, que deverá se consolidar com a posse do novo presidente". 177

Foram precisos quase 50 anos para que as Organizações Globo fizessem, publicamente, a revisão histórica do seu posicionamento favorável ao Golpe Militar de 1964. Em editorial publicado no dia 31/8/2013, e lido pelo jornalista William Bonner em tom solene, no Jornal Nacional, as Organizações Globo fizeram seu "mea culpa”:

A consciência não é de hoje, vem de discussões internas de anos, em que as Organizações Globo concluíram que, à luz da História, o apoio se constituiu um equívoco. Já há muitos anos, em discussões internas, as Organizações Globo reconhecem que, à luz da História, esse apoio foi um erro (O GLOBO, 2013).

O editorial traz afirmações sobre as manifestações de junho de 2013, quando eclodiram protestos em todo o País contra várias questões não resolvidas pelo Governo: “...Um coro voltou às ruas: "A verdade é dura, a Globo apoiou a ditadura”. De fato, trata-se de uma verdade, e, também de fato, de uma verdade dura..." Segundo o editorial, essas "duras lembranças" causam muito incômodo, mas comprovam que a decisão do conglomerado - em reconhecer o erro - foi mais acertada.

Outro fato, certamente, pode ter ajudado a empresa a acelerar essa declaração pública. Era lugar-comum, no início da década de 1980, especialmente nas manifestações que pediam a volta da legalidade, que as pessoas entoassem um refrão que acabou se tornando um bordão naquela época: “O povo não é bobo, abaixo a Rede Globo". Essa manifestação deixava clara a percepção de que a sociedade tinha conhecimento do apoio da TV Globo aos militares. Atualmente, quase 30 anos após o Golpe, nos protestos de junho de 2013, em frente ao Congresso Nacional, os manifestantes entoaram este mesmo refrão: "O povo não é bobo, abaixo a Rede Globo", ocasião em que o jornalista Caco Barcelos, da TV Globo, foi hostilizado e acabou saindo do local da manifestação sem fazer seu trabalho.

Em relação ao editorial de reconhecimento do "equívoco", o jornal tentou se desculpar dos desacertos do passado, lembrando alguns fatos da conduta de Roberto Marinho, na tentativa de elevar seu conceito e assegurar que ele era uma pessoa justa e preocupada com seus colaboradores, como mostra o trecho a seguir:

\footnotetext{
${ }^{177}$ Editorial com o título: Julgamento da Revolução, O Globo, 7/10/1984. Acesso em: 12 fev. 2013.
} 
Durante a Ditadura de 1964, Roberto Marinho sempre se posicionou com firmeza contra a perseguição a jornalistas de esquerda: como é notório, fez questão de abrigar muitos deles na redação de $O$ Globo. São muitos e conhecidos os depoimentos que dão conta de que ele fazia questão de acompanhar funcionários de $O$ Globo chamados a depor: acompanhava-os pessoalmente para evitar que desaparecessem. Instado algumas vezes a dar a lista dos "comunistas" que trabalhavam no jornal, sempre se negou, de maneira desafiadora... Ficou famosa a sua frase ao general Juracy Magalhães, ministro da Justiça do presidente Castello Branco: "Cuide de seus comunistas, que eu cuido dos meus". ${ }^{178}$

Em 1984, quando efervescia a campanha pela volta das eleições diretas, o jornal $O$ Globo, assim como a TV Globo, tentou abafar as manifestações populares a favor das DiretasJá, distorcendo informações e minimizando o impacto dos protestos. Em 1989, na primeira eleição direta para presidente, depois do Regime Militar, a rede Globo fez o que pôde para evitar a vitória do candidato do Partido dos Trabalhadores e apoiou, sem escrúpulos, o candidato Fernando Collor de Mello cujo personagem ajudara a construir. O golpe de misericórdia foi o comentado e alardeado debate entre Lula e Collor, que foi manipulado pelos editores da TV Globo para favorecer a vitória de Collor.

Após a redemocratização do País, no governo de José Sarney, que se tornou presidente por causa da morte de Tancredo Neves, era cada vez maior a influência do dono do jornal $O$ Globo nos rumos do País. Não era por acaso que se comentava que Roberto Marinho decidia até quem seria ministro de Estado. Em sua autobiografia, publicada em 2010, o ex-ministro da Fazenda, Maílson Ferreira da Nóbrega, não só admite que Marinho foi fundamental na sua escolha para ministro, como conta como o episódio sucedeu, revelando que soube da confirmação do seu nome pelo plantão do Jornal Nacional do dia 5 de janeiro de 1988 (SOTTOMAIOR; LEONEL, 2010). ${ }^{179}$

Na virada do ano de 1987 para 1988, Nóbrega estava como ministro interino da Fazenda e foi chamado pelo então presidente Sarney a sua casa de praia na Ilha do Curupu, em São Luís, no Maranhão. Conversaram sobre a conjuntura econômica e aquela foia primeira conversa longa que tiveram, pois antes os encontros eram apenas protocolares. Nóbrega estava interinamente no cargo de ministro, depois da saída intempestiva do exministro Bresser Pereira.

No encontro, Sarney confirmou a Nóbrega sua intenção de confirmá-lo no cargo, mas avisou que ele teria de esperar alguns dias para que ele "conversasse com líderes políticos e

\footnotetext{
${ }^{178}$ Apoio editorial ao golpe de 64 foi um erro. Disponível em: <http://oglobo.globo.com/pais/apoio-editorial-aogolpe-de-64-foi-um-erro-9771604\#ixzz2tY6c ONJO>.

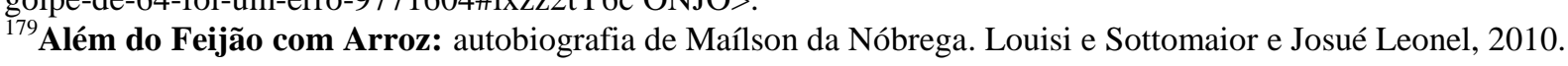
Ed. Civilização Brasileira, 591 p.
} 
outras pessoas". Em seguida, revelou: "quero antes conversar com o doutor Roberto Marinho" (NÓBREGA apud SOTTOMAIOR; LEONEL, 2010, p. 380). Segundo Nóbrega nesta mesma obra (2010), era importante que o presidente do maior grupo de mídia do País apoiasse o novo líder da pasta. Ao voltar a Brasília, depois de conceder muitas entrevistas após o encontro com o presidente, Nóbrega revela em suas memórias que "estava muito ansioso" (NÓBREGA apud SOTTOMAIOR; LEONEL, 2010, p. 381) com a repercussão da imprensa.

Naquela noite, Nóbrega aparecia em todos os telejornais, menos na TV Globo. "Externei meu estranhamento a algumas pessoas, "pode ser que o Roberto Marinho esteja trabalhando por outro nome". Isso seria confirmado a Nóbrega 24 anos depois, pelo próprio Sarney. A preferência de Marinho era pelo então presidente do Banco do Brasil, Camilo Calazans" (NÓBREGA apud SOTTOMAIOR; LEONEL, 2010, p. 380).

Antes de contar o desfecho, Nóbrega conta que "não sabia o que pensar naquele momento. Será que o doutor Roberto era influente a ponto de indicar o ministro da Fazenda ou desaprovar o seu nome?". A partir daquele episódio, Nóbrega revela que passou a enxergar muitas semelhanças entre o empresário William Hearst e o dono da TV Globo. Foi esse empresário americano, considerado magnata da TV americana, que inspirou Cidadão Kane, filme de Orson Welles, de 1941. Nóbrega reitera, “a impressão seria reforçada em momentos bem menos agradáveis” (NÓBREGA apud SOTTOMAIOR; LEONEL, 2010, p. 381).

Outro caso que também foi revelador do autoritarismo de Roberto Marinho aconteceu um pouco antes e foi denunciado pela imprensa na ocasião. Durante a eleição do exgovernador Leonel Brizola, ao governo do Rio de Janeiro, em 1982, a TV Globo e o jornal $O$ Globo protagonizaram uma escandalosa tentativa de fraude. Para impedir que Brizola fosse eleito, a empresa Proconsult tentou fraudar os resultados e na ocasião foi denunciada a participação do dono do jornal, Roberto Marinho. O episódio desgastou a imagem do jornal, pela postura política aliada a políticos neoliberais.

Não por acaso, alguns anos depois, em 1993, Roberto Marinho impediu que um documentário com acusações à sua emissora fosse reproduzido no Brasil. O programa produzido em Londres recebeu o nome de "Muito além do cidadão Kane" e foi produzido pela BBC com participação de pessoas importantes do Brasil como Chico Buarque e Leonel Brizola. Nesse documentário, o ex-governador Leonel Brizola afirma que "Roberto Marinho é uma espécie de Stálin das comunicações do nosso país” e o cantor e compositor Chico 
Buarque afirma que "Roberto Marinho é a força política mais importante do nosso país e nada é feito sem consultá-lo". 180

Em 1998, Roberto Marinho deixou seu legado nas mãos dos seus três filhos, que herdaram o mesmo posicionamento do pai em relação ao Partido dos Trabalhadores. Essa tomada de posição ficou bem clara em 2005, quando veio à tona o chamado "escândalo do mensalão". Os meios de comunicação, comandados pelos irmãos Marinho, fizeram um tipo de cobertura que foi chamada de "cobertura adversária", que virou tema de doutorado na Faculdade de Comunicação da UnB ${ }^{181}$.

Pode parecer estranha essa "cobertura adversária", uma vez que, classicamente, um dos atributos do jornalismo é o de atuar como "cão de guarda" vigilante dos princípios nobres do jornalismo. Mas a tipificação é válida, pois a Globo, depois do Golpe Militar e após a volta dos civis ao poder ocupado ora pelo PMDB, ora pelo PSDB, sempre se posicionou de forma benevolente e até omissa em relação aos erros e fracassos dos governos que antecederam ao mandato de Lula. Com relação à Confecom, o jornal $O$ Globo, assim como a TV Globo, tocou no assunto quando anunciou a saída das seis entidades que abandonaram a organização do evento em agosto de 2009. Uma semana antes da realização da Conferência, o jornal publicou

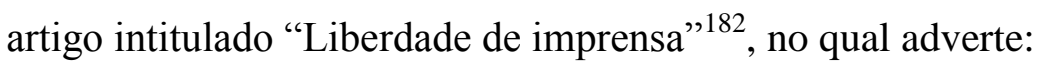

Nenhum governo gosta da liberdade de imprensa. Afinal, a imprensa investiga fatos, sendo importante fator de contenção do avanço do poder estatal sobre nossas liberdades. Governos com viés autoritário toleram ainda menos esta liberdade de investigar e criticar (O GLOBO, 2009).

Esse artigo traz informações sobre a pauta da Conferência, alertando para o risco de serem aprovadas medidas contra a liberdade de imprensa. Em praticamente todas as matérias sobre a Confecom, o jornal cita que as entidades empresariais abandonaram o evento por serem contrárias a qualquer possibilidade de volta da censura à imprensa, como se isso estivesse em pauta.

Seria preciso muito mais que uma tese de doutorado para que o atestado de antecedentes das Organizações Globo pudesse ser dissecado. A relação da rede Globo com a história do Brasil e o papel desempenhado pelo conglomerado de mídia até 2003, quando o

\footnotetext{
${ }^{180}$ Disponível em: <http://www.xonei.com/5-verdades-que-voce-nao-sabia-sobre-a-rede-globo/>.

${ }^{181}$ GUAZINA, L. Jornalismo em busca da credibilidade: a cobertura adversária do Jornal Nacional no escândalo do mensalão. Tese (Doutorado) - Universidade de Brasília, 2011.

${ }^{182}$ Artigo publicado no jornal $\boldsymbol{O}$ Globo, 8/12/2009, p. 6.
} 
PT subiu ao Poder, precisam ser compreendidos para que se possa entender que tipo de mídia e que tipo de sociedade temos hoje.

De acordo com o Instituto de Veiculação de Circulação (IVC), O Globo tem uma tiragem de 297 mil exemplares diários.

\subsection{Como foi a cobertura dos sites pesquisados}

Tanto o Fórum Nacional pela Democratização da Comunicação (FNDC) como o site do Coletivo Intervozes - escolhidos para representar as entidades sociais nesta pesquisa demonstraram comportamento semelhante nos meses que antecederam à Confecom; os dois acompanharam as conferências estaduais, apresentaram e discutiram propostas regionais, ouviram especialistas em comunicação e, em alguns episódios construíram um diálogo enviesado com os representantes da mídia tradicional.

Durante os quatro dias de duração do evento, os dois sites trouxeram matérias que refletiam as discussões travadas entre as entidades do movimento social pela democratização da mídia e os empresários representantes do setor privado, mas faltou um aprofundamento equilibrado do que poderia representar cada uma das proposições aprovadas. Era como se o assunto fosse de domínio público, sem a necessidade de maiores explicações, como se o leitor destes sites já fosse um leitor cativo e esclarecido. Neste ponto, os jornais, apesar da resistência com relação aos temas, apresentavam as proposições de forma mais didática, falavam com um leitor que não tinha a obrigação de conhecer profundamente o assunto, falavam para o leitor comum, e não para um suposto militante da causa.

Percebeu-se uma carga ideológica expressiva nestes relatos, em muitas matérias o setor empresarial foi colocado como um adversário a ser combatido, e o cenário da Conferência como um campo de batalha. A ideologia do dominado ficou claro no material dos sites, como se só estes trouxessem a voz dos oprimidos pela mídia retrógada e poderosa, como se tudo fosse preto ou branco, como há 25 ou 30 anos, quando os posicionamentos de esquerda e direita assumiam contornos mais claros e definidos. Hoje existe uma coloração cinzenta, observa-se posicionamentos que ora corroboram teses da dita esquerda, mas ora apostam que não há porque se falar em regulações rígidas, uma vez que a internet derreteu fronteiras e criou território de livres pensadores.

Mas a ideologização da cobertura não foi um "privilégio" apenas dos sites. Os jornais, vez por outra, também apostaram neste viés quando se colocaram como vítimas exclusivas da censura do regime militar, deixando de lado que - em muitas ocasiões -também foram 
coniventes com o regime militar. Mas quando se trata de associar um possível acompanhamento por observatórios do que a mídia produz, imediatamente ele é apontado como censura.

O movimento social estava dividido, muitos grupos não queriam negociar para que a Conferência acontecesse, embora a ala mais aberta ao diálogo tenha prevalecido. Em muitos produtos do site foi possível perceber o interesse para que o diálogo entre o segmento tradicional da mídia, representado pela grande imprensa, fosse retomado com as entidades que lutam pela democratização dos meios de comunicação. Se não houvesse um entendimento para que os empresários permanecessem a Conferência poderia não ter acontecido.

E essa preocupação existia bem antes dos dias da realização do encontro. A preocupação do movimento- pouco menos de dois meses da realização da Confecom - era que as conferências regionais não valorizassem conflitos ou disputas. Para o representante da Secretaria-Geral da Presidência na Comissão Organizadora, Gerson Almeida, “o momento é de unificar lutas e propostas, e todos devem estar presentes no processo de organização: empresários, Governo, sociedade civil. Não podemos perder a dimensão que estamos construindo uma conferência nacional,", ${ }^{183}$

a Confecom é um sucesso. Apesar de todas as dificuldades enfrentadas no seu processo de organização, foi possível conseguir colocar na mesa de discussão segmentos que tradicionalmente não dialogam, e assegurou a participação tripartite no processo. (ALMEIDA, 2009).

Faltando 10 dias para o início da Confecom, o entusiasmo das entidades sociais era enorme. Celso Schroder ${ }^{184}$, então vice-presidente da Federação Nacional dos Jornalistas (Fenaj), comemorava que os problemas da comunicação do País saíam da invisibilidade:

Era preciso romper o silêncio e a invisibilidade que a comunicação tinha no País - ressaltou - nossa opinião pública é moldada pelos grandes meios e fazer um debate sobre eles era fundamental, para permitir que a sociedade e os próprios meios pensem outras possibilidades e desnaturalize um pouco o processo.

A expectativa de Schroder (2009), coordenador-geral do Fórum, era construir um consenso entre as partes, e que a sociedade civil se "colocasse como a grande avalista do processo",

\footnotetext{
${ }^{183}$ Disponível em: <http://www.fndc.org.br/print.php?=conteudo\&cont_key=446049>.

${ }^{184}$ Disponível em: <http://www.fndc.org.br/print.php?=conteudo\&cont_key=446049>.
} 
o Governo teve o grande mérito de convocar a Conferência, mas foi a sociedade civil que propôs a agenda e ajudou a reunir todos os agentes no processo. Ela procurou os empresários e tem se mostrado generosa, tolerante e disposta a acatar posições contrárias. Tudo sem preconceito. Não é uma arena de disputas irresponsáveis. Aqui (na Confecom) não haverá vencedores ou perdedores a priori. Estamos juntos para ajudar a produzir, racional e cuidadosamente, políticas para a comunicação. ${ }^{185}$

O outro lado, o dos empresários, também receava que a conferência tomasse rumos que eles não aprovassem. Em um seminário promovido pelo Instituto de Defesa do Consumidor (Idec), pelo Intervozes, pela Fundação Getúlio Vargas e pelo Núcleo de Pesquisas, Estudos e Formação da Rede de Informação do Terceiro Setor (Rits), estava presente o empresário da rede Bandeirantes, Walter Ceneviva, ligado à Associação Brasileira de Radiodifusores (Abra), que foi um ator importante do setor empresarial de mídia no debate, e que também esteve na Confecom, mesmo quando os outros empresários do segmento desistiram de participar.

Ceneviva (2009) alertou, na ocasião, que "para a viabilização da Conferência é de crucial importância para a evolução dos meios de comunicação que não haja controle social do conteúdo, que significa censura e interferência política". Este é um discurso recorrente dos empresários da mídia tradicional, que foi repetido à exaustão no cenário da Conferência. Ele revela que, por trás desta defesa, está cristalizada a postura do empresariado em não negociar a criação dos conselhos de comunicação. Este foi um dos tantos pontos que afastaram o consenso entre estes dois segmentos, e foi também alvo de polêmica e resistência durante a Constituinte.

O membro do Intervozes, João Brant (2009), lembrou - durante a preparação da Conferência - "da dificuldade que tem sido o processo de construção da Confecom, exatamente pela resistência de empresários e do Governo em relação à abertura de debate em certos temas". Também ressaltou a situação de verdadeira desregulação em que se encontra o setor de radiodifusão: "hoje há todos os tipos de barreiras para se conseguir uma concessão na TV aberta. Nem capitalismo de concorrência temos, mas de capitanias hereditárias", comparou $^{186}$. Ao contrário dos jornais, o movimento social em defesa da democratização dos meios de comunicação estava vivendo um momento ímpar. Há anos não se discutia tanto a comunicação no País. Se os jornais não queriam falar do assunto, os sites mergulharam no

\footnotetext{
${ }^{185}$ Confecom pode servir de base para projetos no Congresso. Disponível em: $<$ http://blog.planalto.gov.br/confecom-pode-servir-de-base-para-projetos-no-congresso/>.

${ }^{186}$ FNDC. Disponível em: <http://www.fndc.org.br/print.php?=conteudo\&cont_key=444081>.
} 
debate. Em 26 de outubro de 2009, o Fórum publicou uma matéria conclamando todos para que "as divergências fossem superadas e a Confecom pudesse acontecer". ${ }^{187}$

As divergências, que pareciam ter sido superadas, quase impedem a realização da Conferência. Logo no primeiro dia dos trabalhos, houve uma polêmica com relação ao regimento que iria ser adotado durante as votações nos Grupos de Trabalho, o que já havia sido tratado. O Grupo Bandeirantes ameaçou não participar da Confecom se as mudanças no regimento que eles queriam não fossem aceitas. Este desentendimento provocou até o então presidente Lula, que acabou tendo que forçar os movimentos sociais a aceitar as mudanças, que já haviam sido acertadas pela Comissão Organizadora. A CUT, a Fenaj e o FNDC atenderam aos apelos do presidente e aceitaram as mudanças, que permitiam a arguição do mecanismo da questão sensível nos Grupos. O Coletivo Intervozes e a Abraço recusaram.

O impasse foi superado, mas acabou por revelar este tipo de estratégia de confronto com o inimigo, como ficou claro em artigo publicado pelo FNDC no dia 15/12/2009, que considerou este acordo "uma vergonha".

Para se ter uma ideia do estrago, muita gente ameaçava abandonar a Confecom depois dessa manobra vergonhosa... É preciso entender quem é o inimigo principal. O editorial da Globo contra a Confecom e a chantagem da Band mostram quem é o adversário principal. ${ }^{188}$

Esta reação também revela uma face complexa dos movimentos sociais que, naturalmente, se refletiu no tipo de cobertura dada ao evento: a falta de consenso dentro do próprio movimento. Embora, as entidades concordem com as questões mais gerais sobre a democratização dos meios, elas começam a se desentender com relação a questões mais profundas e pontuais e também com relação aos meios de se chegar aos resultados desejados. Esta falta de coesão, com certeza, enfraquece a batalha que é travada com o segmento privado de mídia. Algumas entidades se mostraram mais avessas ao diálogo, chegando a defender que a Conferência fosse realizada sem a presença dos empresários, que as discussões ficassem apenas entre os representantes do movimento.

Posturas como essas, ainda que não tenham prevalecido, revelam a face precária do movimento como um todo, que aparentemente defende a democracia, mas resiste em dialogar com quem está do outro lado, esquece que o poder da comunicação é hoje um bem intangível

\footnotetext{
187 Confecom: superar divergências e garantir o seu caráter nacional. FNDC. Disponível em: <http://www.fndc.org.br/print.php?=conteudo\&cont_key=446049>.

${ }^{188}$ Lula pede e CUT cede aos empresários na Confecom, 15\12\2009. O artigo foi escrito pelo jornalista Rodrigo Vianna do Portal Vermelho e foi replicado pelo FNDC. Disponível em: $<$ http://vermelho.org.br/especiais/noticia.php?id_noticia=121337\&id_secao=6>.
} 
que cada vez mais é preciso ser negociado, que não está mais nas mãos apenas do segmento privado da mídia, embora este ainda tente conservar os seus tentáculos de poder.

No artigo, o jornalista Rodrigo Vianna ${ }^{189}$, fez duras críticas aos delegados da CUT, e da Fenaj por eles terem cedido às pressões, sem levar em conta que este entendimento viabilizou a presença dos empresários, que por sua vez, emprestou legitimidade à Conferência:

Os dirigentes que tomaram essas decisões vão pagar o preço por elas. Entre o Governo aliado à Band e os movimentos sociais, dirigentes da CUT preferiram ficar com a postura "chapa branca"... Tiveram uma postura subserviente e dúbia - favorecendo a chantagem empresarial. ${ }^{190}$

\subsubsection{O Fórum Nacional em Defesa da Comunicação (FNDC) diante da Confecom}

Durante a Confecom, além das matérias de cobertura das negociações e das votações, o Fórum trouxe artigos e entrevistas de personalidades ligadas à área, com destaque para professores de universidades, filósofos e especialistas que acompanharam a evolução das negociações. Não só durante a Conferência como nos meses de sua preparação, o Fórum produziu artigos questionando a resistência dos representantes da mídia tradicional em participar da Confecom. Além disso, posicionou-se em variadas questões conflitantes como o fim da propriedade cruzada dos meios de comunicação, a criação de mecanismos de controle da atuação da mídia, como os Conselhos de Jornalismo, e o fim da criminalização das rádios comunitárias. Em cada categoria estas matérias serão apresentadas.

O FNDC, reconheceu que, apesar de questões centrais não terem sido enfrentadas como o movimento social gostaria, o fato de a Conferência ter acontecido foi um grande passo: "a primeira Conferência Nacional de Comunicação representou indiscutivelmente uma importante vitória das forças progressistas do Brasil". ${ }^{191}$ Especialmente a TV Globo e o jornal O Globo que dedicaram espaço para destruir a imagem dessa Conferência como se não fosse possível fazer um evento democrático na área da comunicação sem a anuência desses setores,

\footnotetext{
${ }^{189}$ Rodrigo Vianna é jornalista, e atualmente trabalha na Rede Record e assina um blog chamado "O escrevinhador". Chegou a trabalhar durante quase onze anos na TV Globo e desde então tem feito críticas à emissora.

${ }^{190}$ Lula pede e CUT cede aos empresários na Confecom, 15\12\2009. Intervozes replica artigo do Portal Vermelho. Disponível em: 〈http://vermelho.org.br/especiais/noticia.php?id_noticia=121337\&id_secao=6>.

${ }^{191}$ Confecom: uma primeira vitória, uma nova etapa na longa luta. Disponível em: <WWW.fndc.org.br/>. Em: 21/12/2009.
} 
perceberam que isso aconteceu. "Este era um tema proibido, hoje é agenda do Estado e da sociedade". ${ }^{192}$

Esse discurso reflete bem o clima de euforia que se seguiu ao final do encontro entre as entidades e muitos representantes do Governo. O que se assistiu depois da Conferência, todavia, foi um novo resfriamento com relação ao avanço da regulação democrática dos meios de comunicação, mas isto não vem ao caso neste momento. O final do encontro foi mesmo celebrado pelos movimentos sociais.

Neste mesmo artigo, que foi republicado também no Observatório do Direito à Comunicação, o articulista e jornalista Beto Almeida afirma que acredita que os empresários que não foram à Conferência, mas que representam uma grande fatia do empresariado "sentiram o golpe". "A reação vista na mídia revela que os grandes magnatas sentiram o golpe, pois para eles é inadmissível que o tema Democracia na Comunicação seja tratado pública e democraticamente". 193

Para a oligarquia midiática, qualquer ação feita com o sentido de criar políticas públicas para a comunicação é inevitavelmente "censura estatal, pois tratam a mídia como se fosse um latifúndio, uma indústria de alimentos contaminados, uma fábrica qualquer de medicamentos falsificados, embora bem embalados”. Para finalizar, Almeida (2009) ressalta que a grande diferença é que “o governo atual não está interessado em censura, mas em promover a democratização da comunicação e de construir uma aliança com os movimentos sociais e com os setores não monopolistas do empresariado". ${ }^{194}$

Desde julho de 1991, quando o FNDC ${ }^{195}$ foi criado como um movimento social ele se mostrou firme na luta pela democratização dos meios, e depois se transformou em entidade em 20 de agosto de 1995. Reúne, praticamente, as mais importantes e sérias associações e entidades da sociedade civil que lutam pela criação de uma marco regulatório democrático para a comunicação no Brasil.

No final da década de 1980, apesar de ainda ter representação limitada, o Fórum (antes de ganhar este nome) atuou ativamente na finalização dos trabalhos da Assembleia Nacional Constituinte, em 1988, na preparação do Capítulo V da Comunicação Social. Na ocasião, as entidades formavam a então Frente Nacional por Políticas Democráticas de Comunicação e só

\footnotetext{
${ }^{192}$ Confecom: uma primeira vitória uma nova etapa na longa luta. Disponível em: <www.fndc.org.br/>. Em: $21 / 12 / 2009$.

${ }^{193}$ Confecom: uma primeira vitória, uma nova etapa na longa luta. Disponível em: <http://www.direitoa comunicacao.org.br /content.php?option=com_content\&task= view\&id=5986>.

${ }^{194}$ Disponível em: <http://www.direitoacomunicacao.org.br/content.php?option=com_content\&task=view\&id $=5986>$.

${ }^{195}$ FNDC: $<$ http://www.fndc.org.br/>.
} 
depois é que se transformou em Fórum. A ideia que prevaleceu foi a de que era preciso criar uma associação civil com atuação no planejamento, mobilização, relacionamento, formulação de projetos e empreendimento de medidas legais e políticas para promover a democracia na Comunicação.

Em quase 23 anos de história, o Fórum tem participado de todos os movimentos e ações que envolvem assuntos relativos à legislação dos meios de comunicação e a relação da mídia com sociedade e com o governo. A Confecom foi o movimento que consolidou e ampliou ainda mais a atuação do Fórum. De acordo com informações do próprio site:

\begin{abstract}
A primeira Confecom teve grande representatividade com a participação de entidades da sociedade, do empresariado e do Poder Público. O movimento nacional de democratização da Comunicação recebeu o reforço de novos atores como coletivos de comunicação, blogueiros e jornalistas independentes; e movimentos sociais que não o da Comunicação, como o movimento sindical, das mulheres, movimento negro, movimento LGBTT, entidades ligadas à juventude e dos trabalhadores do campo, entre outros (FNDC, 2009).
\end{abstract}

Atualmente, o Fórum está presente em 18 estados brasileiros, com 44 comitês regionais, e conta com a participação de 235 entidades, entre estas, os sindicatos de jornalistas, de trabalhadores em empresas de telecomunicação, da Associação Brasileira de Radiodifusão Comunitária (Abraço), da Frente Nacional pela Valorização das TVs do Campo Público (Frenavatec), do Núcleo de Comunicação Daniel Herz, do Centro de Estudos da Mídia Alternativa Barão de Itararé - Barão de Itararé, Instituto Patrícia Galvão - Mídia e Direitos (SP). Todas essas entidades mandaram representantes à Confecom e aumentaram o número de delegados que representou o movimento social em defesa da democratização da mídia.

O Fórum é mantido por doações dos participantes e pela contribuição mensal de $R$ \$ 20,00 de todas as entidades filiadas, e ainda pela renda resultante de projetos e pesquisas. Há cerca de pouco mais de um ano, o estatuto do FNDC sofreu algumas alterações e passou a incluir a participação de pessoas físicas, e não apenas de entidades, como era até então. Além disso, a Federação Nacional de Jornalistas (Fenaj) deixou de compor a direção nacional do Fórum.

O programa do FNDC passa uma imagem de amadurecimento da entidade como no seguinte trecho: "o Fórum enfrentou o desconforto de lidar com algo mais do que "palavras de ordem”, fórmulas fixas, ideias fechadas e soluções definitivas, e dedicou-se a aprender o convívio com o precário, o provisório e o instável, características próprias da realidade 
humana". Além disso, reitera que a luta pela democratização "passou a ser encarada como um esforço que deve ser permanente, como uma atitude a ser despertada nos cidadãos, estimulada na sociedade, compreendida no setor privado e impulsionada pelo Estado". Apesar da luta, do esforço e do empenho, a entidade tem consciência de que "nunca teremos no Brasil uma plena democratização da comunicação". 196

\subsubsection{O Coletivo Intervozes diante da Confecom}

O material produzido pelo Coletivo Intervozes, que aprofundou e problematizou com mais qualidade as questões centrais da polêmica entre os dois lados do debate, não escondeu o otimismo com a realização da Conferência. De modo geral, os representantes dos movimentos acharam que a Confecom avançou no debate sobre a democratização dos meios de comunicação.

No dia seguinte ao encerramento da Confecom, o Coletivo Intervozes trouxe uma matéria celebrando a realização do encontro. O sociólogo e professor do Departamento de Jornalismo e Editoração da Universidade de São Paulo (USP), Laurindo Leal Filho, comemorou: "A Confecom conseguiu fazer, em 4 dias, em termos de análise crítica e propostas consistentes, mais do que se fez nos últimos 80 anos", 197

"Era uma discussão que estava interditada. Não se discutia isso no Brasil. A Conferência abriu a porta. Ainda é uma fresta pequena, mas eu acho que ela abriu a porta e a gente tem que colocar o pé nessa fresta para mantê-la aberta e ampliá-la ainda mais", ressaltou o professor Leal Filho, acrescentando que a Confecom teria sido um sucesso mesmo diante de todas as dificuldades como os empresários fazendo uma série de exigências e parte deles se retirando do processo. De acordo com Leal, “os que ficaram também fizeram mais exigências, quase tornando o Governo e a sociedade civil reféns deles. Ainda assim tudo foi superado."198

"Os que apostaram no fracasso da Confecom caíram do cavalo. Além do valor histórico desse processo e do seu sentido pedagógico reuniu milhares de pessoas para debater a comunicação"199. A tônica é do editorial do Portal Vermelho, republicado no Intervozes

\footnotetext{
${ }^{196}$ Disponível em: <http://www.ufrn.br/sites/engenhodesonhos/mediateca/artigos/programaFNDC.pdf>

${ }^{197}$ Brasil supera em 4 dias 80 anos sem debate na comunicação. Disponível em:

$<$ http://www.intervozes.org.br/direitoacomunicacao/?p=23764>.

${ }^{198}$ Brasil supera em 4 dias 80 anos sem debate na comunicação. Disponível em: <http://www.intervozes.org.br/direitoacomunicacao/?p=23764>.

${ }^{199}$ Primeira fase da Confecom aprova propostas democráticas. Disponível em:

$<$ http://renatamielli.blogspot.com.br/2010/02/1-fase-da-confecom-aprova-propostas.html>.
} 
(2009) e elaborado com a convicção de que o consenso foi alcançado pelos participantes do embate.

Parte considerável das propostas aprovadas ( $80 \%$ dos votos) não era consenso entre os três setores representados na Conferência. Elas puderam ser aprovadas nos grupos graças ao diálogo e à negociação entre movimentos sociais, Governo e empresários que, com o maior espírito republicano, perceberam que não adianta tapar os olhos à realidade". ${ }^{200}$

De acordo com o editorial, "é preciso construir instrumentos de modernização nas políticas de comunicação que estejam pautadas pela garantia do acesso e pela pluralidade”.

O Coletivo Intervozes, logo após o final da Confecom, publicou matéria no site com características mais editorialistas do que noticiosas, a começar pelo título ${ }^{201}$.

No artigo, o site faz um breve balanço do encontro, ressaltando seu lado positivo:

...aqueles que erradamente apostaram na explosão da Confecom e se retiraram da sua construção - refiro-me à Abert, Aner, ANJ e entidades empresariais que representam os interesses de empresas como a rede Globo, Folha de S. Paulo, O Estado de S. Paulo e outros veículos que se negaram a participar do debate democrático sobre as comunicações, foram os derrotados (INTERVOZES, 2009).

Segundo avaliação do Intervozes (2009), quando essas entidades se retiraram, lá atrás, era na esperança de que o xeque-mate fizesse o Governo recuar e desmobilizar a Conferência, mas "esses setores assinaram um atestado de intolerância e derrota... e agora não terão outro caminho a não ser mudar de postura". Para a entidade, que luta pela regulação democrática dos meios de comunicação, aquele setor tradicional da mídia, que não quis aceitar o debate, construiu - em décadas de hegemonia informacional - uma imagem estereotipada dos movimentos sociais como "extremistas, radicais, intransigentes, baderneiros e toda a sorte de adjetivos pejorativos - mas o que conseguiram foi mostrar intransigência. Querem calar a todos, mas foram calados" (Idem).

O editorial do Intervozes reconhece que a participação dos representantes das empresas de telecomunicações e de emissoras como a Band e Rede TV foram fundamentais para legitimar a Conferência. "Eles não correram amedrontados, vieram defender seus interesses. $\mathrm{Na}$ sociedade da informação, num mundo digital no qual se desvanecem e se misturam os papéis de receptor e emissor, não há mais espaço para a unilateralidade no processo comunicacional." (Idem)

\footnotetext{
${ }^{200}$ Conferência aponta novos rumos para a Comunicação no Brasil. Intervozes, 18/12/2009.

${ }^{201}$ Confecom: o lamento dos derrotados. Disponível em: <http://Intervozes.Org.Br/Noticias/Confecom-OLamento-Dos-Derrotados>, em 17/12/2009.
} 
Em atividade desde 2002, o Intervozes - Coletivo Brasil de Comunicação Social ${ }^{202}$ - é uma organização que trabalha pela efetivação do direito humano à Comunicação no Brasil. Para o Intervozes, “o direito à comunicação é indissociável do pleno exercício da cidadania e da democracia. Uma sociedade só pode ser chamada de democrática quando as diversas vozes, opiniões e culturas que a compõem têm espaço para se manifestar”.

O coletivo é formado por ativistas e profissionais com formação em Comunicação Social e em outras áreas, distribuídos em 15 estados brasileiros e no Distrito Federal. Cada associado do Intervozes é, ao mesmo tempo, um promotor de ações locais e um colaborador na formulação e realização de estratégias nacionais adotadas pelo coletivo.

O site criou um importante espaço de debate e divulgação dos assuntos relativos à democratização dos meios de comunicação e sempre teve papel atuante na luta pelo direito à Comunicação. Desde novembro de 2005, o Intervozes também desenvolve o Centro de Referência para o Direito à Comunicação. O objetivo desse projeto é contribuir para a criação de um ambiente favorável para a luta pelo direito à Comunicação, oferecendo aos atores desse campo referências concretas que potencializam sua atuação. A produção jornalística do site sobre a Confecom seguiu o mesmo perfil do material produzido pelo FNDC.

O Intervozes é mantido com doações dos associados, além de recursos advindos com a publicação de estudos e pesquisas. De acordo com o art. 43 do Estatuto da entidade, as fontes de recurso são as seguintes:

a) contribuições dos associados;

b) doações e dotações, legados, heranças, subsídios e quaisquer auxílios que lhe forem concedidos por pessoas físicas ou jurídicas, de direito privado ou de direito público, nacionais ou estrangeiras, bem como os rendimentos produzidos por esses bens;

c) receitas provenientes dos serviços prestados, da venda de publicações e outros produtos, bem como as receitas patrimoniais; receitas provenientes de contratos, convênios e termos de parceria celebrados com pessoas físicas e jurídicas, de direito público ou privado;

d) receitas de eventos festivos, acadêmicos ou beneficentes, visando angariar recursos para atender seus objetivos;

e) receitas de eventuais sorteios de bens doados, respeitada a lei peculiar.

\footnotetext{
${ }^{202}$ Site do Intervozes: <http://www.intervozes.org.br/>.
} 
Além disso, conta com o financiamento de entidades internacionais como a Fundação Ford, que financia projetos na área da Comunicação, sempre como foco nos mecanismos e instrumentos que garantam o direito humano à Comunicação.

\section{$5.4 \mathrm{O}$ que as categorias revelaram}

A finalidade do recorte dos conteúdos, aqui chamados de "unidades temáticas" é uma estratégia que faz parte da metodologia que ajuda a organizar o caos encontrado no corpus recolhido. Estes elementos são agrupados em cada uma das categorias de acordo com a sua significação, e elas juntas e interpretadas começam a trazer respostas. A seguir a apresentação e problematização das categorias criadas na presente pesquisa.

\subsubsection{Liberdade de imprensa, de expressão e controle social da mídia}

O "controle social da mídia", embora tenha sido o ponto mais nevrálgico das discussões entre o setor empresarial, entidades sociais e Governo, acabou ficando fora dos eixos temáticos da Confecom exatamente pela polêmica que o cerca ${ }^{203}$. Para evitar confrontos mais diretos, o tema ficou de fora, mas isso não impediu que ele tangenciasse, praticamente, todas as questões mais centrais da agenda de debates. Mas a exclusão formal gerou descontentamentos nas entidades do movimento de acordo com o desabafo de uma das representantes do Coletivo Intervozes, Bia Barbosa, feito na ocasião:

Controle social é um dos temas mais debatidos em todas as etapas preparatórias que estão acontecendo no Brasil. Simplesmente excluí-lo do temário oficial para ceder, mais uma vez, à chantagem dos empresários, mostra o quão fragilizada a sociedade civil está entrando neste processo. ${ }^{204}$ (INTERVOZES, 15/12/2009).

Para o Coletivo Intervozes, em longo artigo publicado no último dia da Confecom, "o controle social" é a principal bandeira de todo o movimento social envolvido com a Conferência Nacional de Comunicação. Segundo o artigo, para os empresários e uma parte do Governo, o controle seria uma forma de censurar os meios de comunicação, "e não uma forma de garantir a participação popular nas políticas públicas do setor” (Intervozes, 17/12/2009). Embora o tema tenha ficado fora dos eixos temáticos diversos segmentos ligados às entidades

\footnotetext{
${ }^{203}$ O tema "controle social da mídia" foi trocado por "participação social na comunicação" e ficou no eixo de Cidadania. O temário foi definido no dia 9/9/2009.

${ }^{204}$ Comissões fazem críticas ao regimento interno e ao temário, mas seguem na mobilização. Intervozes, 7/10/2009. Disponível em: <http://intervozes.org.br/comissoes-fazem-criticas-ao-regimento-interno-e-aotemario-mas-seguem-na-mobilizacao/>.
} 
sociais elaboraram propostas nessa direção, e em alguns casos elas foram aprovadas, como é o caso da criação dos conselhos de comunicação.

O entendimento do Coletivo Intervozes é que o "controle social" deve ser percebido em duas dimensões; o da exigibilidade do direito à comunicação e o da participação da sociedade na implementação e fiscalização das políticas públicas. Para a primeira dimensão, é necessário a criação de mecanismos que garantam aos cidadãos acesso a fontes variadas de informação, além de instrumentos que protejam o cidadão em face dos conteúdos que por ventura ataquem princípios que atinjam a dignidade humana e o respeito às diferenças. Para atingir tal propósito, a ideia seria a instalação de uma procuradoria dos direitos dos usuários dos serviços de comunicação, que além de proteger esses direitos, pudesse ajuizar ações para a garantia e efetivação desses mesmos direitos.

A presidente a ANJ (Associação Nacional dos Jornais), Judith Brito, cuja entidade não participou da Confecom, alegou que quando o leitor se sentir ofendido, basta que o cidadão entre com uma ação no Judiciário para garantir os seus direitos e se defender de eventuais danos. Ou seja, uma ação desta natureza entraria na vala comum dos processos que atolam as Varas Cíveis e demandaria um tempo imensurável para a sua solução. Ou seja, se não for criada uma instância só para cuidar dos crimes da imprensa contra o cidadão, dificilmente este direito estará protegido.

De acordo com o Relatório Justiça, divulgado pelo CNJ (Conselho Nacional de Justiça) “o número de processos em trâmite no Judiciário brasileiro cresceu 10,6\% nos últimos quatro anos e chegou a 92,2 milhões de ações em tramitação em 2013"205. As eventuais ações de direito de resposta, por exemplo, seriam misturadas a este universo e seguiria o prazo "normal" de tramitação. No entanto, a presidente da ANJ, afirma simplesmente que "basta" que o leitor ou telespectador entre com uma ação no Judiciário para ser atendido em seus direitos. Ocorre que o "direito de resposta" tem uma particularidade: para ele ter efetividade ele tem que ser atendido em ate 24 horas após o recebimento da reclamação. Ou seja, a correção de eventual erro por parte do jornal deve ser imediatamente posterior à ofensa ou à difamação.

\footnotetext{
${ }^{205}$ Número de processos em trâmite no Judiciário cresce $10 \%$ em quatro anos. Disponível em: <http://www.cnj.jus.br/noticias/cnj/26625:numero-de-processos-em-tramite-no-judiciario-cresce-10-em-quatroanos $>$.
} 
Além do "direito de resposta" o antigo Código Brasileiro de Telecomunicações, de 1962, ainda em uso, prevê que a emissora ou jornal que tenha cometido tal crime -seja a veiculação de conteúdos inverídicos ou a manipulação de informações deliberadamente deve também sofrer uma punição. Esta punição, no caso de várias reincidências, pode até ensejar o cancelamento da licença ou outorga concedida ao prestador de serviço, no caso das emissoras de rádio e TV. Ocorre, que raramente é vista alguma punição aos órgãos de imprensa.

Para enfrentar esta inação, O Coletivo Intervozes chegou a propor que seja obrigatório e conste nos contratos de concessão e permissão de rádio e TV este compromisso com o direito de resposta ao cidadão eventualmente ofendido. Para isso, o ideal seria que houvesse uma relação de proximidade entre os veículos de comunicação e o cidadão. "Para potencializar esta relação o Coletivo Intervozes propõe a instalação de conselho de telespectadores, ouvidorias e serviço de ombudsman, para a garantir a transparência e a possibilidade de cidadãos e cidadãs se expressarem quanto à prestação do serviço". 206

Este artigo do Intervozes lembra que no Brasil, especialmente em áreas mais afetas aos direitos humanos, como na saúde, assistência social, juventude, infância, adolescência, direito dos idosos, já foram implantados mecanismos que possibilitam a participação da sociedade na implementação dos serviços e principalmente na fiscalização dos mesmos. "Enquanto que na comunicação "não existe qualquer espaço de participação popular. Ao contrário, as tentativas de silenciar a voz da população são constantes"207. Estes temas se entrelaçam na discussão global da comunicação, sem a regulação - defendida pelo movimento - as demais demandas se tornam mais difíceis de serem atendidas. E por trás dessa discussão está a questão central que é a liberdade de imprensa e expressão versus controle social, como entendem os empresários; enquanto que as entidades sociais fazem outra leitura: liberdade de imprensa com controle social, o que é inaceitável para o setor privado da mídia.

É natural que a pesquisa tenha eleito este tema "Liberdade e Controle" como a primeira categoria a ser criada, lembrando que o nome Liberdade abarca tanto a de expressão como de imprensa. Foi esta categoria que trouxe os primeiros resultados acerca dos

\footnotetext{
${ }^{206}$ Controle social exige participação e mecanismos que garantam o direito à comunicação. Intervozes, 17/12/2009. Disponível em: <http://intervozes.org.br/controle-social-exige-participacao-e-mecanismos-quegarantam-o-direito-a-comunicacao/ $>$.

${ }^{207}$ Controle social exige participação e mecanismos que garantam o direito à comunicação. Intervozes, 17/12/2009. Disponível em: <http://intervozes.org.br/controle-social-exige-participacao-e-mecanismos-quegarantam-o-direito-a-comunicacao/>.
} 
argumentos que cada lado da disputa deixou transparecer como "entraves para a criação de um novo marco regulatório para a comunicação no Brasil”".

Com base no conteúdo selecionado dentro do material empírico, foram identificados 87 fragmentos manifestados pelos jornais e 43 fragmentos manifestados pelos sites acerca da liberdade de expressão/liberdade de imprensa. Desde o início da Conferência, e mesmo a partir das matérias que foram produzidas sobre o evento, durante a sua preparação, o denominador comum na fala dos empresários da mídia tradicional era o risco de a Confecom estabelecer algum mecanismo de "controle social" da mídia e a consequente censura à imprensa.

Enquanto os jornais argumentavam que o "controle social da mídia" era um eufemismo para falar de censura, os sites argumentavam que era preciso construir mecanismos de controle público articulando a sociedade e o Estado, para acompanhar a mídia. Os jornais, por sua vez, conseguiram - desde o fim do regime militar em 1985 - convencer a sociedade brasileira de que eles são que carregam a bandeira da liberdade de expressão e de imprensa, porque foram muito atingidos pela censura e advogam que qualquer tipo de controle social é uma afronta a essa liberdade, conquistada depois de muita luta.

Só que até o fím do regime militar, quando toda a sociedade civil se uniu para defender a voltar dos direitos civis e do restabelecimento do Estado de Direito, essa demanda era única, mas com a volta à normalidade muita coisa mudou e a sociedade civil assumiu várias formas e se multifacetou, surgindo diferenças de como o regime democrático foi se estabelecendo no país. E boa parte da sociedade não se viu contemplada e acolhida pelos meios de comunicação que se consolidaram, se tornaram verdadeiros aparelhos privados de hegemonia, ditando o que devia ou não devia ser publicado, o que devia ou não ser discutido. E a mídia passou a decidir a agenda pública do país.

Os movimentos sociais, por sua vez, embora bem intencionados, não conseguiram enfrentar esta hegemonia - cristalizada especialmente na TV Globo - e não conseguiram levar a bandeira da democratização da mídia para toda a sociedade. Embora seja claro que existe um oligopólio estabelecido nas empresas de comunicação do país, que o processo de concessões e outorgas é viciado, a sociedade não toma como sua o enfretamento destes entraves. A discussão de um tema como esse não ganha as ruas, embora tenha ganhado visibilidade durante a Confecom, ainda não é prioridade entre as demandas populares. Além disso, a irreversibilidade da revolução tecnológica que torna cada cidadão um repórter da sua rua, com uma internet que abre espaço para anônimos, fica difícil convencer a população da 
necessidade da criação de mecanismos mais específicos e robustos que garantam a liberdade de imprensa.

Os jornais, naturalmente, insistiram em defender que essa liberdade, tão proclamada, poderia ser ameaçada pelas decisões da Confecom. O bombardeio contra essa ideia começou, com ênfase, poucos dias antes do início do encontro. No dia 8 de dezembro de 2009, $O$ Globo publicou longo artigo de 50 linhas, em três colunas, na editoria de opinião, assinado pelo economista Rodrigo Constantino ${ }^{208}$, com o título, sem adjetivação, Liberdade de imprensa.

Antes mesmo de adentrar na discussão de tal conceito, garantiu: "Nenhum governo gosta da liberdade de imprensa”. Segundo Constantino (2009) argumentou, isso é muito normal, pois, "afinal, a imprensa investiga fatos, sendo importante fator de contenção do avanço do poder estatal sobre nossas liberdades”. Mais uma vez, ele não esclarece a qual liberdade se refere, nem de quem, se das pessoas, das empresas...

Governos com viés autoritário toleram ainda menos essa liberdade de investigar e criticar. Não por acaso, todas as ditaduras tentam controlar a imprensa, vista como inimigo prioritário em seus projetos de poder absoluto. ${ }^{209}$

Depois de fazer referência aos acontecimentos na América Latina, já mencionados, o mesmo artigo assegura:

No Brasil, desde a tentativa fracassada de controle por meio do Conselho Nacional de Jornalismo, "o governo não desistiu do sonho de amordaçar a imprensa". Como claro porta-voz do setor privado de mídia, ele afirma que é "este o contexto da Conferência Nacional de Comunicação (Confecom) que será realizada em Brasília no próximo dia $14 .{ }^{210}$

“Sob o manto da 'democratização' da imprensa - as aspas são do autor do artigo, com a intenção de ironizar o termo e desautorizá-lo - o artigo vai mais longe: o Governo pretende estender seus tentáculos por todo o setor, asfixiando sua liberdade". (2009). Em seguida, cita a Resolução que o PT baixou para a Confecom, comentada aqui em artigo publicado em $O$ Estado de S. Paulo e assinado pelo deputado Claudio Vignatti (2009), do próprio Partido dos Trabalhadores: "a resolução estratégica lançada pelo PT para o evento pode ser resumida em uma única palavra: censura.

\footnotetext{
${ }^{208}$ Rodrigo Constantino é advogado e é ligado a Álvaro Dias (senador do PSDB) e também é articulista da Revista Veja.

${ }^{209}$ Liberdade de imprensa, artigo, $\boldsymbol{O}$ Globo, 8/12/2009, p. 13.

${ }^{210}$ Liberdade de Imprensa, artigo, O Globo, 8/12/2009, p. 13.
} 
Aquilo que o partido chama de "controle social" nada mais é do que os antigos conselhos comunistas. A palavra final fica com o Governo, o novo censor disfarçado de "fiscal" da transparência (aspas do autor para ironizar o termo). Eufemismos, no entanto, não podem ocultar a natureza da coisa (Idem).

A afirmativa "antigos conselhos comunistas" foi usada propositadamente para provocar no leitor sua memória em relação ao Golpe de Estado de 1964. Os jornais da época, em editoriais e matérias, repetiam à exaustão, que o Brasil estava à mercê "da ameaça comunista" antes do golpe militar. O artigo lembra esse discurso de João Goulart para sustentar o argumento de que o controle social é uma estratégia adotada pelos comunistas em seus conselhos decisórios, sugerindo que o PT defende este tipo de controle para instituir a censura aos jornais.

Quem não se lembra das passeatas, denominadas "Marcha da família com Deus pela Liberdade" ${ }^{211}$ que começaram em 19 de março de 1964 e que foram consideradas como resposta à "ameaça comunista", após o comício do então presidente João Goulart no dia 13 de março? Nesse comício histórico, Jango teria prometido realizar reformas profundas no País. Mas os jornais, que temiam as decisões de Jango, insistiam em associá-lo aos comunistas dizendo que ele queria censurar a imprensa e instituir o regime comunista no país. A censura, todavia, veio depois com os militares.

O artigo do jornal $O$ Globo diz ainda que não é só da censura que o Governo pode lançar mão "caso queria manipular a imprensa". Segundo o articulista Constantino (2009), que se apresenta apenas como economista, "a mais óbvia forma é por meio de polpudas verbas de propaganda, inclusive das estatais". Num país com enorme presença do Governo na economia, esse fator merece destaque. "O cão que morde não morde a mão que o alimenta"essa analogia, que depõe contra a própria imprensa, provocou na pesquisa referência a outra formação discursiva, que cabe aqui ser lembrada: a da figura honrosa do jornalista como "um verdadeiro cão de guarda dos valores da sociedade, da ética, da honestidade e da justiça”, como bem qualificou o jornalista Marcondes Filho (2000, p. 58).

Um desses cenários tem a ver com o jornalista que representava o "jornalismo militante e libertário", vigilante das ações do Estado e defensor das causas perdidas. O outro tem a ver com aquele que foi engolido pelo jornalismo mercadológico e industrial.

\footnotetext{
${ }^{211}$ Marcha da família com Deus pela propriedade. Disponível em: <http://cpdoc.fgv.br/producao/dossies/Jango/artigos/AConjunturaRadicalizacao/A_marcha_da_familia_com_De us $>$.
} 
Certamente, o articulista está se referindo a esse tipo de imprensa, que se submete aos constrangimentos do mercado e do Poder, para continuar existindo.

A expressão tão cara ao jornalismo “"cães de guarda', cuja missão é proteger os cidadãos dos abusos do poder, é uma imagem recorrente no imaginário coletivo dos jornalistas" (ADGHRNI, 2011). Essa é a imagem "do herói intransigente da democracia, que inspirou peças, livros e filmes" 212 como "Todos os homens do presidente" (1976) - para ficar só nesse exemplo. No filme, os jornalistas do Washington Post, Carl Bernstein (interpretado por Dustin Hoffman) e Robert Woodward (interpretado por Robert Redford) investigam o famoso escândalo Watergate que, em 1972, derrubou o presidente dos Estados Unidos, Richard Nixon (ADGHRNI, 2005).

Antes de finalizar, o mesmo articulista, em artigo de $O$ Globo, ataca a mídia pública que o País possui:

O arsenal de munições do Governo é vasto. Até mesmo uma herança da ditadura Vargas sobrevive, a 'Hora do Brasil', que invade as rádios do País todo na hora do rush. Um canal 'chapa branca' de televisão também foi criado, mas felizmente o público o ignora por completo. O custo acaba sendo "apenas" os impostos cobrados para sustentar a máquina de proselitismo. Agora o Governo tenta mais uma vez controlar a imprensa. ${ }^{213}$

Constantino, ainda em seu artigo sobre a Liberdade de Imprensa, utilizou de conceitos de John Milton e Thomas Jefferson para usá-los como lhe convém, afirmando que "cabe a cada um julgar por conta própria o que é bom ou ruim". E finaliza dizendo que "Trotsky e Lênin consideravam a imprensa uma arma perigosa e desejavam proibir a circulação de jornais 'burgueses'. A História mostrou os riscos dessa mentalidade”.

Esta referência alude a um fato recorrente na mídia, que é a discussão superficial do conceito de liberdade de expressão em contraponto à liberdade de imprensa. Fatos que corroboram discursos cristalizados ao longo da história do embate entre as entidades sociais e o segmento privado do campo da comunicação. A discussão do conceito de liberdade é recorrente em estudos dessa natureza e é quase impossível garantir quando o tema foi pela primeira vez consolidado como o internalizamos no mundo atual.

Os estudos jornalísticos apostam que o panfleto Areopagítica, de John Milton (1644), teria sido o primeiro clássico a tratar do tema, ao se referir ao direito natural do indivíduo de

\footnotetext{
${ }^{212}$ Identidade profissional do Jornalista. Disponível em:

$<$ http://www.almanaquedacomunicacao.com.br/jornalismo-online-e-identidade-profissional-do-jornalista-zeliaadghirni/>.

${ }^{213}$ Liberdade de imprensa, artigo, $\boldsymbol{O}$ Globo, 8/12/2009, p. 13.
} 
expor e imprimir suas ideias sem restrições. É consenso que ele não se referia, naquela ocasião, à liberdade de imprensa, uma vez que ainda não existiam jornais na Inglaterra em meados do século XVII, conforme Lima (2010, p. 23). O texto original refere-se à liberdade de imprimir sem licença. Por essa razão, ele foi apresentado no parlamento inglês, pela defesa dessa liberdade, e qualquer impressão a ser feita tinha de ter autorização prévia do Imprimateur do Estado, de acordo com o trecho a seguir:

Nenhum texto podia ser publicado naquele país (Inglaterra) sem obter primeiro a permissão de um oficial designado pelo governo para inspecionar os textos que pretendiam ser publicados (LIMA, 2010, p. 42).

Em 2011, após o escândalo do jornal "News of the World”, do empresário Rupert Murdoch, o Areopagítica foi novamente lembrado. O jornalista Alberto Dines traçou um paralelo entre o Areopagítica e o Relatório Levenson (que tratou do processo contra o jornal de Murdoch), no qual lembra que muitos daqueles preceitos foram esquecidos e precisam ser resgatados. O jornalista Luciano Martins Costa, no site Observatório da Imprensa (2012), ressaltou que existe um movimento em ação, provocado pelo escândalo do jornal inglês:

Apesar de os jornais brasileiros não terem acompanhado com muito interesse
as discussões anteriores à aprovação do relatório, agora não se pode mais
ignorar o fato de que o país que foi o berço da liberdade de informação está
colocando em dúvida a capacidade da imprensa, como instituição, de
assegurar um equilíbrio aceitável entre o conceito de absoluta autonomia
para os órgãos de comunicação e a necessidade de prevenir ou punir desvios
motivados por conveniências políticas, econômicas ou ideológicas (COSTA,
2012, in OBSERVATÓRIO DA IMPRENSA). ${ }^{214}$

Para Dines (2012), com uma diferença de pouco mais de 368 anos, o relatório do lorde-juiz Brian Levenson, com 1.977 páginas, foi também apresentado ao parlamento britânico, como o fez John Milton em 23 de novembro de 1644:

Separados por quase quatro séculos, John Milton e Brian Levenson estão juntos do lado do interesse público e do bem comum: o sonho libertário de buscar o conhecimento irrestrito iniciado em 1644 completou-se em 2012 com o estabelecimento de regras para defender os cidadãos da barbarização através da informação (DINES, 2012, in OBSERVATÓRIO DA IMPRENSA). ${ }^{215}$

\footnotetext{
${ }^{214}$ Disponível em: <www.observatoriodaimprensa.com.br>. Em 1/12/2012, Ed.722.

${ }^{215}$ Disponível em: <www.observatoriodaimprensa.com.br>. Em 1/12/2012, Ed.722.
} 
Milton buscou sua inspiração em Atenas, lembra Dines (2012). O termo dado ao seu manifesto Areopagítica, fazia referência a um monte chamado Areopagus, que existia na Grécia e onde se realizavam discussões e julgamentos. Naquela época, o imperador Isócrates queria restabelecer o poder do tribunal do monte. Já Milton queria resgatar o poder do parlamento inglês. E o juiz Brian Levenson, ainda que não tenha usado essas palavras, deixou claro em seu relatório a precariedade do sistema de autorregulação da imprensa britânica, e trouxe de volta um debate também temido pela imprensa brasileira, a regulação. Levenson, segundo Dines (2012), quer resgatar a presença da ética na busca da informação e da verdade, pois,

ao concluir a seção sobre prática e cultura ética no jornalismo, Levenson afirmou reconhecer que "a maior parte do que a imprensa faz é bom jornalismo, livre do tipo de vícios a que tive que me referir". "Porém", diz ele, "é essencial que a necessidade por um novo começo da regulação da imprensa seja amplamente adotada e que seja implementadoum novo regime a partir de agora" (LEVENSON apud DINES, 2012).

Fatos recentes, como o fechamento do jornal "News of the World" 216 e o escândalo sexual dos diretores da $\mathrm{BBC}$ de Londres $^{217}$, não poderiam ter sido mais oportunos para trazer de volta o debate sobre a regulamentação dos meios de comunicação. Isso reforça a pertinência desta pesquisa e mostra que, apesar da resistência dos donos da mídia, os debates que por ventura tendem a crescer na Inglaterra respingarão sobre o que for discutido aqui no Brasil sobre o assunto.

Mais do que nunca, a liberdade, tão apregoada pelos empresários midiáticos, não poderá mais ser evocada sem trazer, a tiracolo, a preocupação com a responsabilidade e a ética pelo que é divulgado. Dos tempos de John Milton aos de agora muita coisa mudou, é evidente, mas os princípios canônicos que garantem a democracia, a livre circulação da diversidade e da universalidade da liberdade de expressão e do direito à comunicação, seguem reiterados e protegidos, como afirma Dines:

O processo é o mesmo, não desandou. A busca de informações sem constrangimentos continua com o mesmo empenho, agora acrescida da preocupação pela lisura na sua obtenção. A humanidade não abre mão da prerrogativa de buscar o saber sem tutelas. A conquista da liberdade no século 17 completou-se agora no início do século 21 com a consagração do

\footnotetext{
${ }^{216}$ No dia 8 de julho de 2011, o News of the World, jornal dominical mais vendido da Grã-Bretanha, anunciou que deixaria de circular devido ao seu envolvimento em um escândalo de escutas telefônicas ilegais.

${ }^{217}$ A crise na cúpula da BBC foi causada pelo escândalo de pedofilia envolvendo o ex-apresentador Jimmy Savile, morto no ano passado. Os diretores da emissora teriam evitado a divulgação do caso.
} 
princípio da responsabilidade. Liberdade sem deveres é fraude, é isso que Levenson nos oferece de forma tão clara e cabal (DINES, 2012). ${ }^{218}$

Por trás deste discurso da mídia, aparentemente preocupado com as garantias da liberdade, há uma real intenção de evitar que a liberdade assegurada à sociedade atrapalhe a liberdade da empresa de dispor da comunicação como um bem privado, e não um direito humano e público.

É evidente que quando $O$ Globo encomenda um artigo para falar da liberdade ele não o faz inocentemente, a intenção é desvelada pelo discurso inscrito nos enunciados escolhidos pelo articulista. No caso do artigo citado acima, ele retoma a mesma memória discursiva do início do artigo, quando fala dos "conselhos comunistas", buscando assombrar o leitor com o risco do totalitarismo. Embora até reconheça, ao finalizar que... "se alguns grupos concentram muito poder por conta do seu tamanho, então a solução é mais competição e não mais governo", ele não observa que a opção pode ser "mais regulação". E arrematou seu raciocínio simplista: "nós não precisamos do filtro do Governo na imprensa. O que precisamos é de mais liberdade ainda". Que "nós" é esse a que ele se refere? Essa é uma estratégia do artigo, que foi quase um editorial. Ele se incluiu nesse "nós" forçando uma identificação com a audiência, falando como se falasse em nome do povo, buscando, portanto, cumplicidade

No dia 9 de dezembro de 2009, cinco dias antes da Conferência, o jornal $O$ Globo publicou outro artigo e, dessa vez, da então presidente da ANJ, Judith Brito ${ }^{219}$. Apesar de não mencionar diretamente a Conferência, ela usou o espaço para reclamar da censura (já mencionada aqui) que o jornal $O$ Estado de S. Paulo estava sofrendo, por decisão do Tribunal de Justiça do Distrito Federal, com relação às reportagens sobre corrupção que atingiram o filho do senador José Sarney. Ela apelou ao Supremo fazer valer a liberdade de imprensa garantida pela Constituição Federal.

O curioso é que, nesse caso, $O$ Globo - quis que os artigos da Constituição Federal fossem lembrados e cumpridos, mas o mesmo não se dá com os artigos que vêm logo abaixo, no mesmo Capítulo V, da Comunicação, que impede a formação de monopólios ou oligopólios no setor. Ela saudou o fim da Lei da Imprensa e queria que o Supremo agisse do mesmo modo, colocando fim à censura ao jornal. ${ }^{220}$

\footnotetext{
${ }^{218}$ Dines, Alberto. Observatório da Imprensa, 1/12/2012.

${ }^{219}$ Censura, nunca mais. O Globo, 09/12/2009, p. 4.

${ }^{220}$ Por 6 votos a 3, o Supremo Tribunal Federal (STF) negou pedido de liminar do jornal O Estado de S. Paulo contra decisão do Tribunal de Justiça do Distrito Federal (TJ-DF) que proíbe a publicação de reportagens sobre a Operação Boi Barrica, da Polícia Federal. Isso surpreendeu e desagradou o jornal e também a ANJ. No julgamento, prevaleceu o voto do relator, ministro Cezar Peluso, o que mantém a decisão da Justiça do DF.
} 
No dia da abertura da Conferência, $O$ Globo publicou longa matéria, de 60 linhas, em quatro colunas, forçando uma informação até absurda - no lead cita que "na Confecom estarão em debate 6.101 propostas sobre a produção de distribuição de informações jornalísticas e culturais" ${ }^{221}$, quando, na verdade, as propostas tratavam de três eixos diferentes, desde a discussão sobre as rádios comunitárias até questões afetas à neutralidade na internet.

Na matéria, $O$ Globo afirma que "do lado da sociedade, com apoio da União, há forte pressão para o favorecimento das TVs comunitárias e veículos de pequeno porte como, por exemplo, a destinação obrigatória de um terço da verba publicitária oficial". Além de criticar praticamente todas as propostas citadas, o jornal dá amplo espaço para as justificativas dos empresários, que abandonaram a organização da Conferência em agosto daquele ano. A justificativa foi a mesma: “os dirigentes empresariais temem que parte das propostas do encontro relacionadas a suposto controle social dos meios de comunicação resulte na criação de mecanismos de censura ou de inibição de liberdade de imprensa". 222

No dia seguinte, na matéria sobre a abertura do evento, o jornal $O$ Globo destaca que o presidente Lula disse que "a liberdade de imprensa é essencial para a democracia". Para os empresários, a garantia do presidente deveria ser suficiente para evitar qualquer debate sobre a criação do Conselho de Jornalismo ou outro mecanismo de controle. Nessa matéria, o jornal indica os temas que vão ser discutidos no encontro, entre possíveis mecanismos de fiscalização da atividade jornalística, comentando, como porta-voz dos empresários, que: "a atividade jornalística pressupõe liberdade de expressão e não tutela". ${ }^{223}$

A ANJ, também contrária à realização da Conferência, critica a proposta de qualquer controle sobre a mídia e usa o espaço da Folha de S. Paulo para marcar sua posição: "Para Paulo Tonet, da ANJ, o controle social da mídia já existe: é o controle remoto e o jornal da banca. Fora disso é censura, e isso eu não quero mais". ${ }^{224}$

O jornal $O$ Estado de S. Paulo, na edição do segundo dia do evento, afirmou - sem citar fontes - que:

\footnotetext{
Segundo o ministro, "A liberdade de imprensa é plena dentro dos limites conceituais da Constituição". "O texto constituinte não excluiu que não se introduza limites à liberdade de imprensa", argumentou Peluso. Essa decisão provoca importante e oportuna discussão sobre a liberdade de imprensa e a liberdade de expressão e deixa claro que uma não se equivale à outra.

${ }^{221}$ Fórum discute liberdade de informação, $\boldsymbol{O}$ Globo, 14/12/2009.

${ }^{222}$ Fórum discute liberdade de informação, $O$ Globo, 14/12/2009.

${ }^{223}$ Fórum discute liberdade de informação, $\boldsymbol{O}$ Globo, 14/12/2009.

${ }^{224}$ Tribunal de mídia está entre as propostas de governo, Folha de S. Paulo, 14/12/2009, p. A9.
} 
os participantes da $1^{\text {a }}$ Conferência de Comunicação pregam o 'controle social' da mídia - um eufemismo para subordinar o livre fluxo da informação aos interesses dos grupos organizados, que dizem representar a sociedade e incentivam a ingerência do Estado no setor. ${ }^{225}$

Os movimentos sociais reagiram e responderam ao jornal $O$ Estado de S. Paulo. Para o presidente da Fenaj, Sérgio Murillo de Andrade, os empresários do setor de comunicação mal se manifestaram publicamente contra a censura sofrida pelo jornal O Estado de S. Paulo, pela publicação de reportagens sobre a Operação Boi Barrica (que investigou o filho do presidente do Senado, José Sarney), e reclamaram que a Confecom estava criando um conselho para impor censura. Ele entendeu que os empresários são muito seletivos quando se trata de atacar a possibilidade de volta da censura. A decisão judicial sobre o jornal paulista foi uma forma de censura. Murillo defendeu "liberdade extrema de imprensa com responsabilidade"226.

O jornal paulista insistiu na tese do controle, quando afirmou que o "risco real e presente é que a hora seja ajustada para marcar a guinada autoritária que seus adeptos tentaram instituir no primeiro mandato de Lula, com o projeto chavista do Conselho Federal de Jornalismo..." 227 . O presidente da Aner, Roberto Muylaert, também se pronunciou: “um controle social da mídia pressupõe mudança na Constituição, que atualmente assegura a livre iniciativa" $^{228}$. Mais uma vez, os empresários, propositadamente, mergulharam o assunto na “estratégia da confusão" e misturaram liberdade de expressão com livre iniciativa empresarial. O presidente da Adjori-Brasil também se pronunciou na mesma matéria do jornal O Estado de S. Paulo ${ }^{229}$ :

O ex-ministro das Comunicações do governo de Fernando Henrique Cardoso, que participou da Confecom como representante da Telebrasil, Juarez Nascimento, argumentou que a "censura política" praticada no período da ditadura acabou gerando um trauma na sociedade e, consequentemente, deu uma conotação pejorativa para a palavra censura, mesmo quando desacompanhada da palavra política (INTERVOZES, 2009). A partir do segundo dia da Confecom, os sites que trouxeram o ponto de vista dos movimentos sociais, também apresentaram os argumentos contrários à regulação democrática dos meios de comunicação. Estes argumentos apresentados pelos empresários foram discutidos pelos sites. Foi percebido,

\footnotetext{
${ }^{225}$ Foco é 'controle social da mídia', O Estado de S. Paulo, 15/12/2009, p. 6.

${ }^{226}$ Ele espera que a Conferência comece a desenhar um novo ordenamento jurídico para o setor, Intervozes, $16 / 12 / 2009$.

${ }^{227}$ Confecom e o 'controle social' da mídia, O Estado de S. Paulo, 16/12/2009, p. A6.

${ }^{228}$ Confecom e o 'controle social' da mídia, O Estado de S. Paulo, 16/12/2009, p. 5.

${ }^{229}$ Controle social arrepia todo mundo, O Estado de S. Paulo, 16/12/2009, p.5.
} 
nestes momentos, um diálogo enviesado entre os dois lados. Como se os movimentos estivessem respondendo aos argumentos das empresas.

Os empresários insistiam na questão da volta do autoritarismo, com respaldo do que estava acontecendo na ocasião na Venezuela e na Argentina ${ }^{230}$ : O diretor-geral da Abert, Luís Antonik (2009), afirmou ao jornal $O$ Estado de S. Paulo que está vendo isso todos os dias na América Latina, medidas de cerceamento à imprensa na Bolívia, Venezuela e Argentina. "Essa liberdade é uma coisa que conquistamos com muito sacrifício", destacou Antonik ${ }^{231}$. Como se vê, o discurso guarda semelhanças com aquele manifesto durante a Assembleia Nacional Constituinte, com a diferença de que, em 2009, as mudanças nos países vizinhos com relação à imprensa geravam um clima de incerteza.

Os três jornais "usaram" os artigos da Constituição e lhes deram a interpretação que desejaram. Essa mesma Constituição - tão citada pelos empresários - no art. 224 determina que o "Congresso Nacional instituirá, como órgão auxiliar, o Conselho de Comunicação Social, na forma da lei”. Essa era a ideia - presente na letra da lei - que os empresários insistiam em rotular de "guinada autoritária". Os empresários se referiam à desconcentração da mídia com a redução dos oligopólios, como se fosse uma novidade autoritária, mas seria apenas o cumprimento do parágrafo $5^{\circ}$ do art. 220 da Constituição Federal de 1988, que afirma: "Os meios de comunicação social não podem, direta ou indiretamente, ser objeto de monopólio ou oligopólio".

O Intervozes, no mesmo dia, divulgou longa entrevista do jornalista e professor, Gabriel Priolli Netto, para mostrar a posição dos movimentos sociais em relação ao controle social:

Os setores empresariais têm intenção de provocar confusão em relação a uma maior participação da sociedade. Não se quer controle estatal e nada tem a ver com censura. Isso é um direito que a sociedade tem e deve exercer. $^{232}$

No dia seguinte, 17/12/2009, a resposta dos movimentos sociais veio com força e a percepção que eles tiveram foi nitidamente oposta ao do jornal O Estado de S. Paulo. $\mathrm{Na}$ opinião do Coletivo Intervozes:

\footnotetext{
${ }^{230}$ Nesta ocasião, na Argentina, a presidente Cristina Kirchner havia promulgado em 10 de outubro de 2009 a nova lei de meios daquele país, que pretendia, entre outras coisas, reduzir a concentração dos meios de comunicação. Na Venezuela, o então presidente Hugo Chaves estava perseguindo os jornais de oposição.

${ }^{231}$ Confecom aprova 'controle social' sobre a mídia, O Estado de S. Paulo, 17/12/2009, p. 4.

${ }^{232}$ Professor defende marco regulatório. Intervozes, 16/12/2009.
} 
o controle social deve seguir o que aponta a Constituição Federal. Em seu art. $220, \S 3^{\circ}$, por exemplo, está expressa a necessidade de lei federal para "estabelecer os meios legais que garantam à pessoa e à família possibilidade de se defender da programação de rádio e de televisão que contrarie o disposto no art. 221... Hoje a população não tem como se defender de forma efetiva desse tipo de prática das emissoras. ${ }^{233}$

A resposta do Fórum veio no mesmo tom: "Os conselhos são fundamentais, uma reivindicação importante da sociedade. Não vemos qualquer papel que possa violar a liberdade de expressão" (FNDC, 2009). O jornal O Estado de S. Paulo, nessa mesma edição, insistiu na argumentação de que diante do mecanismo de controle seja por meio do conselho ou de algum outro órgão fiscalizador: ${ }^{234}$

Os empresários são contrários a essa proposta, as empresas argumentaram que o setor já é fiscalizado pelo Ministério das Comunicações e que o "controle social" pode resultar em algum tipo de cerceamento da liberdade de expressão (FNDC, 2009)

A Abert (que abandonou a Confecom) afirmou no Estado de S. Paulo "ver com preocupação os resultados da Conferência e lembrou as tentativas de cerceamento de liberdade com a criação de conselhos em países latinos"235. "Se estamos numa democracia, o que precisamos é exercê-la em sua plenitude, praticá-la e não cogitar de instâncias ou autarquias para abafar a liberdade de expressão" - completou a presidente da ANJ, Judith Brito $^{236}$. Essas manifestações de resistência à possíveis mudanças na regulação dos meios, em nada diferem do que os empresários do segmento tradicional da mídia sempre defenderam ao longos dos últimos 25 anos.

O jornal $O$ Estado de S. Paulo, por sua vez, afirmou que "os empresários sempre foram contrários a essa proposta (de criação do conselho), argumentando que o setor seria fiscalizado pelo Ministério das Comunicações e que o "controle social" poderia resultar em algum tipo de cerceamento da liberdade de expressão"237. É do conhecimento de todo o setor da mídia que o controle que o Ministério das Comunicações faz é precário e quase inexistente.

\footnotetext{
${ }^{233}$ Intervozes defende controle social em resposta ao Estadão, Intervozes, 17/12/2009. Disponível em: <intervozes.org.br>.

${ }^{234}$ Confecom sugere 'controle social da mídia' e fiscalização do jornalismo. O Estado de S. Paulo, 17/12/2009, p. 6.

${ }^{235}$ Confecom sugere 'controle social da mídia' e fiscalização do jornalismo, O Estado de S. Paulo, 17/12/2009, p. 6.

${ }^{236}$ Confecom sugere 'controle social da mídia' e fiscalização do jornalismo, O Estado de S. Paulo, 17/12/2009, p. 6 .

${ }^{237}$ Confecom sugere 'controle social da mídia' e fiscalização do jornalismo, O Estado de S. Paulo, 17/12/2009, p. 6.
} 
O professor de Comunicação da Universidade de Brasília (UnB), Murilo César Ramos, reconhece que o termo "controle tem uma conotação 'complicada', mas que o objetivo não é censurar, mas ter um ordenamento jurídico mais claro para os meios de comunicação" 238 .

O Coletivo Intervozes, por sua vez, defendeu a criação do conselho e comemorou a realização da Confecom. Segundo longa matéria do site, o evento deixou clara a demarcação de dois caminhos para as políticas de comunicação no Brasil:

De um lado, os que defendem a valorização da diversidade cultural e a democratização da mídia. De outro, grupos familiares que buscam manter as coisas como estão com a liberdade da empresa vigorando em detrimento da liberdade de imprensa. ${ }^{239}$

Para o Coletivo Intervozes (2009), foi um avanço a Conferência ter conseguido, a despeito de toda a resistência dos empresários, discutir mecanismos de controle e aprovar a criação de um Conselho de Jornalismo. "A aprovação da criação do conselho, para o professor da USP Laurindo Leal Filho, foi um fato inusitado: 'Isso vai colocar o Brasil, se for concretizado, junto com as principais nações democráticas do mundo". 240

O jornal $O$ Globo, por sua vez, foi ouvir as entidades empresariais, que sequer participaram das conversações na Conferência: a Abert, a Abranet, a Associação Brasileira de TV por assinatura, a Associação de Jornais e Revistas do Interior do Brasil e a Associação Nacional de Jornais (ANJ) consideram que as propostas de estabelecer um controle social da mídia são uma forma de censurar os órgãos de imprensa, cerceando a liberdade de expressão, o direito à informação e a livre iniciativa - todos previstos na Constituição. ${ }^{241}$

Sobre a criação de conselhos de comunicação, a presidente da ANJ, Judith Brito, em entrevista ao jornal $O$ Globo, comentou que o momento exige "atenção ainda maior da sociedade" e advertiu: "quando se vê abusos cometidos contra o livre exercício do jornalismo, em diversos países latino-americanos, essa ideia de criar conselhos exige da sociedade um grau ainda maior de alerta" ${ }^{242}$. Naturalmente, os acontecimentos na Argentina, com a aprovação da Lei dos Meios, as decisões autoritárias de Hugo Chaves na Venezuela, influenciam os discursos dos empresários do setor.

\footnotetext{
${ }^{238}$ Confecom aprova propostas restritivas ao jornalismo, O Estado de S. Paulo, 17/12/2009, p. 6.

${ }^{239}$ Conferência propõe controle da comunicação. Intervozes, 18/12/2009. Disponível em: <intervozes.org.br>

${ }^{240}$ Confecom aprova resoluções importantes para as organizações sociais. Intervozes, 17/12/2009. Disponível em: <intervozes.org.br>

${ }^{241}$ Proposta aprovada na Confecom sugere criação de Conselho de Jornalismo, O Globo, 17/12/2009, p.11.

${ }^{242}$ Propostas desagradam entidades, O Globo, 17/12/2009, p. 11.
} 
A atividade jornalística, no entendimento de Judith Brito, pressupõe liberdade de expressão e não cautela. Defendeu que a sociedade e os cidadãos é que são os maiores beneficiários dessa liberdade, que lhes dá o direito de terem acesso a todas as informações de seu interesse, sem controles ou tutelas ${ }^{243}$. Este é um discurso convincente para o cidadão, que não vê que por trás, dessa aparente defesa intransigente da liberdade de imprensa, está a defesa da liberdade da empresa de agir como "proprietária da informação" podendo dispor dela como lhe convém, uma vez que não existem mecanismos de controle ou acompanhamento.

Ainda sobre o mesmo tema, o vice-presidente da Band, Ceneviva (2009), considera 'inócua' a proposta do conselho. "Houve uma tentativa de garrotear a imprensa, mas ela foi derrotada" ${ }^{244}$. Na retrospectiva da história da Comunicação, com destaque para o período da elaboração da Constituição de 88, (ver p. 113) o mesmo Ceneviva defendia em 1988, por exemplo, a criação de mecanismos para acompanhar a imprensa.

A Folha traz ainda uma nota, no Painel, para desqualificar a proposta da criação dos conselhos ou de observatórios de mídia e aproveita para criticar o governo do PT: "Em vez de cuidar da TV Brasil, desde sempre traço de audiência, o Planalto realizou a Confecom para tentar controlar a mídia" ${ }^{245}$. É uma clara estratégia de desmoralizar a TV pública, cuja existência está prevista na Constituição, e de buscar marcar território, como se só houvesse espaço para um tipo de televisão, a televisão comercial.

$O$ Globo, na intenção de manifestar o seu desapontamento com a conferência e com rumos dos debates, publicou com destaque uma carta de um leitor, Jayme Ferrari, da cidade de Campos/RJ, com o seguinte teor:

o leitor curioso deveria ler as propostas da $1^{\text {a }}$ Confecom. É só acessar a internet, mas aproveitem enquanto ela ainda é livre ${ }^{246}$. O que pode ser percebido são extenuantes palavras-chave como conselhos, comissões, fiscalizar, coibir, punir, orientar, fixar cotas, monitorar e impedir, repetidas em forma de propostas oficiais para a comunicação nacional que dão arrepios. É bom lembrar os politburos soviéticos e cubanos, os comitês macarthistas americanos e o caso Watergate. ${ }^{247}$

Nessa afirmação Jayme Ferrari (que assina a carta) misturou coisas absolutamente distintas, pois os comitês macarthistas têm a ver com a perseguição imposta pelo então

\footnotetext{
${ }^{243}$ Propostas desagradam entidades, $\boldsymbol{O}$ Globo, 17/12/2009, p. 11.

${ }^{244}$ Confecom não atinge a mídia, afirma empresa e ministro, Folha de S. Paulo, 19/12/2009, p. A1.

${ }^{245}$ Painel, Folha de S. Paulo, 19/12/2009, p. A4.

${ }^{246}$ Imprensa ameaçada. Carta do leitor publicada no jornal, $\boldsymbol{O}$ Globo, 17/12/2009.

${ }^{247}$ Imprensa ameaçada. Carta do leitor publicada no jornal, O Globo, 17/12/2009.
} 
senador americano Joseph McCarthy, que promoveu intensa perseguição política a pretexto de perseguir comunistas e provocou grave desrespeito aos direitos civis dos cidadãos americanos. O caso Watergate (citado aqui) tem a ver com o jornalismo livre e investigativo dos jornalistas do Washington Post. Nada disso tem a ver com os politburos soviéticos, mas é mais uma menção ao regime totalitário da antiga União Soviética.

$\mathrm{Na}$ mesma carta, que foi escolhida por coadunar com os interesses defendidos pelo jornal, esse leitor vai além e afirma que a proposta da Confecom, de $n^{\circ} 5.098$, "é uma pérola". Essa proposta sugere "coibir o excesso de propaganda de comércio de veículos automotores, que induza um padrão de consumo que não corresponde às reais necessidades da população (...)". E finaliza com ironia: "alto lá, camarada: quando resolvem o que corresponde ou não ao padrão de consumo de uma população, de forma exógena, estamos correndo perigo real de uma ditadura". É normal, dentro da lógica capitalista, que prevaleça na mídia o discurso do consumo exagerado e da troca constante de carro pelo modelo do ano.

Ainda no corpus extraído do jornal $O$ Globo, vale a pena interpretar o editorial publicado no dia 19 de dezembro de 2009, após a realização da Confecom, denominado 'Cartas marcadas' e assinado pelo jornalista Ricardo Noblat, cujas ideias se confundem com as dos donos dos jornais. Segundo ele, quando as entidades ANJ e Abert "condicionaram suas participações na Conferência à retirada do temário de qualquer proposta contrária à Constituição e receberam uma negativa o destino da reunião estava traçado”. É bastante emblemático "assistir" um jornalista como Noblat, que já escreveu livros para estudantes de jornalismo, fazer tais colocações e assumir o posto de porta-voz dos donos da mídia.

O interessante é que a ênfase dos representantes dos movimentos sociais, e de boa parcela da imprensa no encontro, foi cobrar do Congresso a regulamentação dos artigos 220, 222 e 223 da Constituição Federal e não aprovar qualquer medida contrária à Carta Magna, como reiteram os jornais.

O editorialista afirmou também que a "Conferência aprovou propostas que vão contra a liberdade de imprensa e de expressão, procuram intervir nas redações e criar obstáculos à ação da iniciativa privada nos meios de comunicação". Segundo ele, a Confecom fez propostas "sem maiores compromissos com a realidade" e "ressuscitou o malfadado Conselho Federal de Jornalismo, entidade paraestatal sugerida... Com poderes para cassar registro de profissionais a serem julgados por algum "conselho de ética", certamente composto por comissários. Algo inspirado no livro 1984, de George Orwell”. ${ }^{248}$

\footnotetext{
${ }^{248}$ Cartas Marcadas. Editorial. O Globo, 19/12/09.
} 
Essa formação discursiva, acionada pelo discurso do editorial do jornal $O$ Globo, chega a ser um clichê. Sempre que se quer falar em vigilância, controle ou cerceamento da liberdade é citado o simbólico livro de Orwell, no qual as pessoas são vigiadas pelo "olho" do grande irmão. O livro mostra o cotidiano de um regime totalitário e repressivo e ficou famoso pela fiscalização e controle do governo na vida dos cidadãos.

Para finalizar, o jornalista lembra os "ovos de serpente", em referência ao possível mal que pode ter sido gestado durante a Conferência, sugerindo que todos devem ficar alertas. “Ovos de serpente como esses (o conselho e a Ancinav) podem ressurgir apenas como expressão da vontade de grupos políticos organizados" (NOBLAT, 2009). A expressão "ovos de serpente" aciona uma referência que vem da Bíblia e está no versículo de Isaías 59:5.

Assim como Noblat considera desnecessário que seja criado um Conselho de Jornalismo, os três jornais analisados abordam o tema de forma semelhante. Para minimizar a necessidade de um observatório de mídia ou de um conselho de acompanhamento do que é produzido pelos jornais ou pela televisão, O Estado de S. Paulo, por exemplo, deixa clara a estratégia em reiterar que qualquer cidadão que se sentir atingido por alguma matéria jornalística tem todo o direito de recorrer à Justiça para garantir seu direito de resposta. Os empresários insistem que essa alternativa seria suficiente para proteger o possível leitor.

Entre as empresas, há o entendimento de que a prática do jornalismo já estaria submetida à legislação brasileira, especificamente ao Código Civil - e que a criação de novos mecanismos de fiscalização pode abrir espaço para a censura. $^{249}$

Para $O$ Globo, "A Conferência aprovou mais uma tentativa do Governo federal de intervir nas empresas de comunicação". Em editorial publicado por O Globo, depois da Confecom, o jornal destacou que, como era previsto, foram aprovadas propostas que vão contra a liberdade de imprensa e expressão, pois "procuram intervir nas redações e criar obstáculos à ação da iniciativa privada nos meios de comunicação. Todos os projetos de vez o inconstitucional” ${ }^{, 250}$. Essa questão da criação dos conselhos e dos mecanismos que oferecem condições para que a sociedade possa acompanhar o que é feito pela mídia foi um dos pontos que dificultaram o consenso durante a Conferência. Embora tenha obtido aprovação, a execução foi desacreditada pelos empresários que compareceram ao encontro. Os que falaram

\footnotetext{
${ }^{249}$ Confecom retoma Conselho Nacional de Jornalismo, O Estado de S. Paulo, 17/12/2009, p. 6.

${ }^{250}$ Cartas Marcadas, O Globo, 19/12/2009, p. 7.
} 
em nome das entidades sociais também tentaram minimizar os impactos da proposta de criação dos conselhos.

O vice-presidente da Fenaj, Schroder (2009), ciente da reação que a volta dos conselhos poderia gerar no empresariado e na tentativa de salvar a proposta que propunha a volta do Conselho de Comunicação tentou amenizar a ideia:

a nova proposta continuará a ser corporativa, mas menos política, deverá constar no novo texto que o CNJ será o fiscalizador do trabalho do jornalista. É como o Conselho Federal de Medicina, que é corporativo, mas também tem uma natureza mais ampla, porque serve à sociedade e pune os maus médicos. ${ }^{251}$

O consultor do jurídico do Ministério das Comunicações, Marcelo Bechara, que participou da organização do evento e coordenou a Comissão Organizadora, em entrevista à Folha, defendeu a ideia do Conselho: "não vejo ameaça à liberdade de expressão no que foi aprovado com relação ao conselho"252. A Folha, por sua vez, minimizou a importância da decisão. O representante da Band, Ceneviva (2009), ouvido pelo jornal, discordou do termo "tribunal de mídia" dado ao conselho por alguns empresários descontentes.

O que está sendo interpretado como tal refere-se à criação de um observatório da mídia para acompanhar as programações e denunciar as violações aos direitos humanos. Isso já existe. O portal Observatório da Imprensa já exerce essa função. Não vejo ameaça nisso. ${ }^{253}$

Indagado sobre a razão de a Band não ter discordado sobre a proposta de criação do conselho - que já havia sido tentada em 2004 e rejeitada por ameaçar a liberdade da imprensa -, Ceneviva (2009) disse que o assunto já foi julgado pelo Supremo Tribunal Federal: “Ou o conselho se estabelece de forma constitucional ou não se estabelece. A proposta aprovada é inócua". 254

O Fórum Nacional em Defesa da Comunicação (FNDC), cinco dias depois da Confecom, tentou reagir às acusações dos empresários de que a Confecom teria aprovado medidas de controle da mídia, quando, de fato, a ideia era de criar algum tipo de acompanhamento mais cuidadoso do trabalho da imprensa. Neste caso, os representantes dos movimentos sociais também fazem uso do sofisma, e tentar argumentar que não se trata de

\footnotetext{
${ }^{251}$ Confecom retoma Conselho Nacional de Jornalismo, O Estado de S. Paulo, 17/12/2009, p. 5.

${ }^{252}$ Confecom não atinge a mídia, afirmam empresa e ministro, Folha de S. Paulo, 19/12/2009, p. A13.

${ }^{253}$ Confecom não atinge a mídia, afirmam empresa e ministro, Folha de S. Paulo, 19/12/2009, p. A13.

${ }^{254}$ Confecom não atinge a mídia, afirmam empresa e ministro, Folha de S. Paulo, 19/12/2009, p.A13.
} 
controle e sim de um simples acompanhamento e observação. A sua fala traz ainda resquícios de uma linguagem um tanto antiquada:

É nítido o motivo da aversão das empresas de comunicação quando se examina a lista das principais teses aprovadas pela Confecom. Elas incluem a criação do Conselho Nacional de Comunicação (que o baronato midiático tenta desqualificar chamando-o de Conselho Federal de Jornalismo, para lembrar a proposta que foi debatida em 2004 e que teve repulsa geral), uma nova Lei de Imprensa, o código de ética para o jornalismo (com a garantia explícita do direito de resposta do acusado por matéria jornalística), a definição de abuso do direito de liberdade de imprensa e as penalidades no caso de transgressões devidamente comprovadas, a cláusula de consciência (inaceitável para os patrões costumeiros em impor aos jornalistas pautas que afrontam sua consciência, sua ética e suas convicções) ${ }^{255}$

Foi possível perceber, durante o curto período da Conferência, que o diálogo entre os movimentos sociais e os empresários da mídia registrou poucos avanços. Algumas críticas dos jornais foram respondidas pelos sites e estes aproveitaram a visibilidade do encontro para defender suas posições e tentar sensibilizar a sociedade para o tema da democratização dos meios, mas não é possível fazer esta avaliação.

O fundamental é que pelos resultados obtidos com foco no confronto de discursos, os dois segmentos, cada qual ao seu modo, optaram pelo atraso, por retomar pontos de vista que não se coadunam com a nova realidade possibilitada pela internet. Não se adequaram ao espírito dos novos tempos, as entidades parecem não perceber que essa liberdade que tanto defendem, está de certa forma, garantida pelo acesso livre à internet; enquanto que os jornais brigam para defender os seus feudos, em um momento que a sociedade lida com a informação de uma forma bem diferente e mais autônoma do que na época da Constituinte. Não é por acaso que nos últimos vinte anos a tiragem dos jornais não apresentou crescimento, e em alguns casos até caiu, embora a população tenha crescido e o número de pessoas com acesso à universidade tenha aumentado.

A seguir, um quadro-síntese com a argumentação de cada um dos lados na categoria "Liberdade e Controle": A íntegra de todas as categorias se encontra em documento anexo.

\footnotetext{
${ }^{255}$ Divisor de águas entre intolerância e o diálogo na Confecom. FNDC, 22/12/2009. Disponível em: $<$ http://www.intervozes.org.br/direitoacomunicacao>
} 
Quadro 8 - Liberdade e controle/síntese

\begin{tabular}{|l|l|}
\hline \multicolumn{1}{|c|}{ Mídia tradicional } & Entidades sociais em defesa da democratização \\
\hline $\begin{array}{l}\text { Controle social vai resultar em cerceamento } \\
\text { da liberdade de expressão. }\end{array}$ & $\begin{array}{l}\text { O controle social é que vai garantir a liberdade de } \\
\text { expressão, pois o setor carece de mecanismos mais } \\
\text { específicos para a fiscalização da imprensa. }\end{array}$ \\
\hline $\begin{array}{l}\text { O livre fluxo da informação será subordinado } \\
\text { aos interesses dos grupos sociais organizados, } \\
\text { que têm vinculação com o partido que está no }\end{array}$ & $\begin{array}{l}\text { Defendem a liberdade de expressão a todos os } \\
\text { grupos, sem distinção, e sem restrição ao direito } \\
\text { hoverno. Essa relação é o que mais preocupa } \\
\text { os empresários. }\end{array}$ \\
$\begin{array}{l}\text { A criação de um código de ética para os } \\
\text { jornalistas, proposto pela Confecom, "seria } \\
\text { uma camisa de força contra o jornalismo, } \\
\text { como o Departamento de Imprensa e } \\
\begin{array}{l}\text { Propaganda (DIP) na ditadura Vargas, na } \\
\text { década de 1940". }\end{array}\end{array}$ & $\begin{array}{l}\text { O código de ética e a criação dos conselhos garante } \\
\text { liberdade ao jornalista e garante uma mídia com } \\
\text { responsabilidade. }\end{array}$ \\
\hline
\end{tabular}

\subsubsection{Marco regulatório para a comunicação}

A resistência à criação de um marco regulatório democrático para a comunicação brasileira esbarra no entrave central a toda essa discussão: a liberdade da empresa versus a liberdade de expressão de cada um. O desejo dos movimentos sociais vai contra a toda intenção do empresariado de deixar as coisas como estão. A não regulação e o “esquecimento" dos artigos. 221, 222 e 223 da Constituição é o cenário ideal defendido pelo setor privado. Enquanto os movimentos desejam diminuir o tamanho do conglomerado midiático nas mãos de poucos grupos, com a revisão das outorgas e concessões, e aumentar o espaço para a participação popular; os empresários preferem tangenciar o assunto e defender tão somente o acesso universal aos meios garantido pela internet e ignorar os demais temas, como a distribuição de conteúdos, a fixação de cotas e a propriedade cruzada.

É um tema no qual o consenso é de difícil alcance, pois ele atinge a hegemonia do segmento privado de mídia, construído desde antes do Golpe de 64 e fortalecido durante e após o regime militar. Há uma resistência histórica a qualquer mudança nesse sentido, uma vez que a sociedade passa ao largo dessa discussão na medida em que as televisões, principalmente a TV Globo, lidera uma expressiva audiência e parece oferecer ao telespectador o que ele deseja como produto. Esta liderança, alicerçada num envolvimento ideológico construído ao longo dos últimos 50 anos, está longe de ser atingida por essa demanda dos movimentos sociais. O que pode por em xeque este poderio global é, certamente, o avassalador desenvolvimento da tecnologia que transferiu para o cidadão o poder de criar e, ao mesmo tempo, distribuir conteúdo a um custo cada vez mais baixo. E não 
uma revisão em um conjunto de leis e regras que se assemelha a uma colcha de retalhos em desalinho.

Esta categoria reuniu 58 "unidades temáticas" do sentido manifesto pela mídia tradicional contrárias ao novo marco regulatório defendido pelas entidades sociais. Enquanto do lado dos sites pesquisados foram encontradas e reunidas 45 unidades a favor de um novo regramento democrático para o setor. Este tema, que dá margem a variadas interpretações, não ensejou grandes confrontos entre os dois lados, como era esperado, pois a questão foi tratada de modo muito genérico durante as conversações. Os dois lados se manifestaram favoráveis à massificação da TV por assinatura e à universalização da banda larga, mas evitaram discutir a fixação de cotas para a produção nacional ou o tema da propriedade cruzada, com a redução do número de empresas na mão de um único grupo empresarial.

O consultor jurídico do Ministério das Comunicações e presidente da Comissão Organizadora Nacional (CON), Marcelo Bechara, tentou uma conciliação. Em matéria do FNDC (2009) afirmou: "Temos que desburocratizar procedimentos dentro do Ministério como as renovações de concessões" 256 . Segundo Bechara, "nesse momento há o amadurecimento de um projeto regulatório para as comunicações com base nesses fundamentos". É imperativa uma "regulação democrática" que assegure que todos os setores estejam articulados com preceitos de universalização e de responsabilidade com suas orientações.

O secretário-executivo da Secretaria de Comunicação Social da Presidência da República, Ottoni Fernandes Júnior, considerou "adequada a existência de um controle através de um órgão regulatório para o conteúdo jornalístico, no caso de concessões de radiodifusão" (FNDC, 2009). Fernandes salientou que existem normas ainda não reguladas no Brasil, no que tange às concessões, como veiculação de publicidade e de conteúdo independente e regional. "Essas questões precisam ser verificadas por um órgão regulador que faça cumprir as determinações legais". 257

O então ministro das Comunicações da época, Hélio Costa, que não desfruta de bom conceito junto às entidades sociais, em entrevista ao FNDC comentou, num tom de lamentação, que se os constituintes não conseguiram impedir a propriedade cruzada em 1988, mais nada pode ser feito. "Sobre as propriedades cruzadas dos meios de comunicação, Hélio

\footnotetext{
${ }^{256}$ Propostas para a construção de uma comunicação democrática. Disponível em: < http://novo.fndc.org.br /noticias/propostas- para-a-construcao-de-uma-comunicacao-democratica-464576/>.

${ }^{257}$ Propostas para a construção de uma comunicação democrática. Disponível em: <http://novo.fndc.org.br /noticias/propostas-para-a-construcao-de-uma-comunicacao-democratica-464576/>.
} 
Costa disse que a Constituinte de 1988 poderia ter tratado do tema, mas não aproveitou a oportunidade". 258

Já o especialista em Internet, advogado e professor Marcel Leonardi, pensa diferente. "Acho que com a Confecom temos a possibilidade de tentar regulamentar de maneira mais democrática do que foi no passado". ${ }^{259}$

O jornal $O$ Globo é, sem dúvida, o órgão que mais apresentou resistência às possíveis mudanças que foram discutidas na Conferência. Até mesmo sobre a classificação indicativa de horários para a programação das emissoras, que é um dos poucos temas que o Governo enfrenta e fiscaliza, ele tentou se insurgir. Em editorial, aparece o seguinte comentário:

As propostas do Governo dividem-se entre as setoriais e as de cunho regulatório. Nesse caso, encaixam-se a regulação da classificação indicativa por lei, o aperto ao cumprimento de número de outorgas (licenças de operação) por grupo empresarial e a restrição à venda de tempo de programação. ${ }^{260}$

Os jornais analisados, entretanto, sempre que se posicionam fazem questão de apostar na "estratégia da confusão". Em artigo no jornal O Globo, Constantino (2009), o setor se manifestou assim: "Não precisamos do filtro do Governo na imprensa. O que precisamos é de mais liberdade ainda. Se alguns grupos concentram muito poder por conta do seu tamanho, a solução é mais competição, não mais Governo". 261

Em matéria publicada pelo jornal $O$ Estado de S. Paulo, na véspera da Confecom, os empresários deixam claro seu pensamento:

...Pela tese proposta de marco regulatório, as ONGs propõem a criação de um comitê para analisar os processos de outorga - um dos objetivos da Conferência é pressionar a favor das rádios e TVs comunitárias. Eles querem descriminalizar as emissoras piratas e propõem inundar o País com canais de TVs públicas... Para cada concessão de TV pirata, devem ser criadas quatro TVs públicas". 262

\footnotetext{
${ }^{258}$ Confecom: tema "controle social da mídia" não vai partir do governo, garante ministro. Disponível em: <http://www.ihu.unisinos.br/noticias/noticias-arquivadas/28193-confecom-tema-\%60\%60controle-social-damidia\%60\%60-nao-vai-partir-do-governo-garante-ministro>.

${ }^{259}$ Por um marco civil da Internet. Originalmente publicado na Revista do Advogado, no 115, v. 32, abr. 2012, Associação dos Advogados de São Paulo (AASP). Disponível em: <http://leonardi.adv.br/2012/04/internet-eregulacao-o-bom-exemplo-do-marco-civil-da-internet/>

${ }^{260}$ Censura, nunca mais, $\boldsymbol{O}$ Globo, 9/12/2009, p. 4.

${ }^{261}$ Liberdade de Imprensa, $\boldsymbol{O}$ Globo, 8/12/2009. p. 3.

${ }^{262}$ Conferência de Comunicação quer recriar cabides de emprego, O Estado de S. Paulo, 13/12/2009, p. 5.
} 
O interessante é que o jornal $O$ Estado de S. Paulo parece concordar, em linhas gerais, com a ampliação da participação do cidadão por meio de um marco regulatório de cunho democrático. Em artigo publicado na véspera da Conferência, o jornal afirma: $\mathrm{O}$ artigo é do deputado do PT, Cláudio Vignatti.

\begin{abstract}
A tecnologia que ocasionou a convergência dos meios e conteúdos, cada vez mais se afirma como processo irreversível e o novo marco regulatório deve ser pautado não apenas para impedir a concentração, mas para ampliar os direitos do cidadão e sua defesa quanto a abusos praticados pela grande mídia $^{263}$. [grifos da autora]
\end{abstract}

Nesse mesmo artigo, o deputado Vignatii (2009) argumenta que a sociedade já participa dos debates das políticas públicas em geral, por isso não viu necessidade em discutir essa questão com relação à comunicação.

Na resolução aprovada pelo PT para a Confecom "consta a necessidade de "criação de instâncias regulatórias que garantam a participação popular na formulação das políticas do setor... Certamente, a participação da sociedade no tocante ao debate das políticas públicas já é fato no atual estágio de democratização do País. ${ }^{264}$

Em matéria comentando "as propostas restritivas" aprovadas na Confecom, o jornal $O$ Estado de S. Paulo foi bastante taxativo ao afirmar, logo no lead, que "as sugestões da Confecom não têm caráter impositivo". Já o Coletivo Intervozes (2009) comemorou as proposições aprovadas, e pediu agilidade: “A sociedade pode esperar uma medida possível de ser implementada pelo Executivo, quase imediatamente. Por exemplo, a universalização do acesso de banda larga pela revitalização da Telebrás"265

Para o jornalista e professor Priolli Neto (2009), a discussão levanta uma cortina de fumaça para que as coisas continuem como são: “um setor pouquíssimo regulado que não tem a ver com a sociedade. O empresariado está acostumado a reinar sozinho nas comunicações e não dar satisfação a ninguém". Neste mesmo dia o jornal O Estado de S. Paulo, em editorial publicado no terceiro dia da Confecom, fez uma afirmação que poderia ter sido aproveitada pelos movimentos sociais se eles estivessem mais atentos aos passos dados pelos empresários. Embora seja uma categoria coesa e unida com objetivos comuns, em alguns pontos eles divergem.

\footnotetext{
${ }^{263}$ Controle versus democratização, O Estado de S. Paulo, 13/12/2009.

${ }^{264}$ Controle versus democratização, O Estado de S. Paulo, 13/12/2009.

${ }^{265}$ Efetivação do sistema público é fundamental para o Intervozes. Intervozes, 17/12/2009.
} 
O jornal O Estado de S. Paulo tem uma postura contrária ao do setor de radiodifusão que fecha os olhos à questão da venda do seu espaço para as igrejas evangélicas. Este é um ponto que enfraquece a coesão do segmento e poderia ter sido mais bem usada como argumento pelas entidades sociais:

\begin{abstract}
A principal das questões que a Confecom poderia se ocupar é a existência dos antidemocráticos monopólios e oligopólios de fato no sistema de rádio e televisão... Elas atentam contra a liberdade de iniciativa, pois tolhem a livre competição no setor... A isso se soma o repasse ilegal de recursos milionários de igrejas para emissoras. ${ }^{266}$
\end{abstract}

Tanto a questão evidente da força dos oligopólios no setor, como a questão do proselitismo religioso na televisão, fazem parte da urgente revisão da legislação, que vai desembocar na criação de um nova marco, uma vez que essas questões seriam enfrentadas com a regulamentação dos artigos. 221, 222 e 223 da Constituição Federal. Esse também é o entendimento do jornalista, professor e sociólogo Laurindo Lalo Leal Filho: "existe a sensação de que algumas demandas não podem mais esperar, como o marco regulatório para a radiodifusão, que já devia ter sido decidido pelo próprio Congresso desde a Constituinte de $1988^{, 267}$

As diferenças entre os dois lados são afetas à fiscalização do comportamento da mídia e ao detalhamento da regulação tanto sobre a definição de cotas de produção e exibição, como sobre o limite de outorgas e a propriedade cruzada. Sobre as linhas gerais, percebe-se um consenso pelo menos retoricamente. Mas a cisão surge quando os pontos centrais são detalhados, se o jornal $O$ Estado de S. Paulo apoiaria a revisão dos oligopólios, o jornal $O$ Globo iria contra, assim como a questão do espaço para as igrejas. A Band é campeã neste quesito, vende uma parte expressiva da sua programação à Igreja Evangélica. Estes pontos de cisão entre eles poderiam ser trabalhados pelas entidades sociais.

Já para $O$ Globo, a regulação é uma ameaça, pois "Projetos idênticos em curso na América Latina, também surgidos de conferências com tinturas democráticas... são projetos destinados a desmontar empresarialmente grupos de comunicação..." ${ }^{268}$. Aqui também é possível notar a mesma estratégia da confusão de conceitos. "A Confecom, como previsto, aprovou propostas que procuram intervir nas redações e criar obstáculos à ação da iniciativa

\footnotetext{
${ }^{266}$ Confecom e o 'controle social' da mídia, (i.e. censura). Editorial. O Estado de S. Paulo, 16/12/2009, p. 4.

267 Ouvidor da EBC defende marco regulatório para a radiodifusão. Disponível em: $<$ http://www.ebc.com.br/sobre-a-ebc/sala-de-imprensa/2009/12/ouvidor-da-ebc-defende-marco-regulatorio-paraa-radiodifusao>.

${ }^{268}$ Confecom aprova medidas restritivas ao jornalismo, $\boldsymbol{O}$ Globo, 18/12/2009, p. 12.
} 
privada nos meios de comunicação" ${ }^{269}$. Em nenhum momento falou-se em intervenção ou obstáculos. É mais uma vez evidente a postura dos empresários tradicionais de confundir o bom debate.

O professor da Faculdade de Comunicação da UnB, Murilo César Ramos, assinalou, em entrevista ao Fórum Nacional de Democratização, que a mídia no Brasil é muito desregulamentada. "O objetivo é ter um ordenamento jurídico mais claro para os meios de comunicação. E o que fizemos aqui na Conferência foi simplesmente reunir as pessoas para esse debate."

Tanto o jornal O Estado de S. Paulo como a Folha se preocuparam em dar destaque para as questões que propunham um novo marco regulatório que impedisse a concentração dos meios de comunicação. O jornal $O$ Globo, por razões óbvias, minimizou esse tema e preferiu insistir nas possíveis ameaças contra a liberdade de imprensa. Naturalmente, pela própria natureza dessas três empresas, há uma aparente cisão. $O$ Globo faz parte de um conglomerado que detém uma concessão pública poderosa, que é a TV Globo, os outros dois jornais são privados e não detêm um canal de TV outorgado pelo Poder Federal, mas nas questões de base mais profundas todos se unem.

O que de fato ocorre é que o jornal O Estado de S. Paulo, neste mesmo editorial do dia 13 de dezembro de 2009, reconhece a necessidade de "um novo marco regulatório" mas, apenas retoricamente. Esta afirmação esconde o que de fato, todo o setor deseja, que nada seja feito. É que não é possível atender apenas a uma empresa e esquecer do restante do segmento. É uma estratégia que os jornais têm usado ao longo dos últimos anos quando são obrigados a se manifestarem sobre o tema. Apoiam um discurso modernizante como este, mas nos bastidores são refratários a qualquer mudança. O jornal insiste que a ideia central da Confecom deve ser essa: atacar os monopólios; e não a discussão sobre o controle social da mídia, muito menos a discussão sobre mecanismos de acompanhamento da produção jornalística.

Sobre a questão da concentração da mídia e o fim de emissoras para políticos, também muito debatido durante a Conferência, a Folha e $O$ Globo foram os dois jornais que mais discutiram o tema. A Folha deu espaço para o então senador Antônio Carlos Magalhães Neto se defender, e $O$ Globo, por sua vez, deu espaço ao então senador Lobão Filho, do PMDB. ACM Neto, cuja família possui seis emissoras de TV na Bahia, além de três emissoras de rádio, afirmou que a medida é “inócua, pois os políticos não vão se desfazer de suas

\footnotetext{
${ }^{269}$ Confecom aprova medidas restritivas ao jornalismo, O Globo, 18/12/2009, p.12.
} 
emissoras, e muitos, provavelmente, irão repassá-las a um laranja, para se enquadrar na lei”. Ou seja, ele admite passar por cima da própria lei e o declara abertamente.

“O senador Edson Lobão, proprietário de uma rede de televisão e rádio no Maranhão, acredita que a mudança na legislação também seja inócua”. Segundo matéria do jornal $O$ Globo, Lobão ressalta que "uma lei não pode retroagir a situações já existentes como a sua". Afirma, ainda, para se justificar, que "as leis eleitorais impedem que políticos usem suas concessões para tirar proveito eleitoral" ${ }^{\text {270 }}$. A seguir, um quadro-síntese com a argumentação de cada um dos lados na categoria "Marco regulatório":

Quadro 9 - O marco regulatório/síntese

\begin{tabular}{|l|l|}
\hline \multicolumn{1}{|c|}{ Mídia tradicional } & Entidades sociais em defesa da democratização \\
\hline $\begin{array}{l}\text { A criação de quaisquer órgãos de controle - } \\
\text { seja de um Conselho de Jornalistas ou um } \\
\text { Tribunal de Mídia - é considerado mecanismo } \\
\text { de ingerência no setor de mídia. }\end{array}$ & $\begin{array}{l}\text { "Imperativa” a regulação dos meios e criação de } \\
\text { instâncias é fundamental para que a sociedade possa } \\
\text { acompanhar e fiscalizar o trabalho da mídia. }\end{array}$ \\
\hline $\begin{array}{l}\text { Os movimentos sociais querem } \\
\text { descriminalizar as emissoras piratas e fundar } \\
\text { novos canais de TVs públicos, de modo que a } \\
\text { imprensa comercial seja prejudicada. }\end{array}$ & $\begin{array}{l}\text { As entidades defendem que as rádios comunitárias } \\
\text { possam ser criadas com menos burocracia e mais } \\
\text { liberdade. Defendem também a criação de TVs } \\
\text { comunitárias }\end{array}$ \\
\hline $\begin{array}{l}\text { Os empresários argumentam que antes de } \\
\text { pensar na criação de novas agências } \\
\text { reguladoras, é preciso aprimorar as } \\
\text { ferramentas de fiscalização e estruturar órgãos } \\
\text { já existentes, como o próprio Ministério das } \\
\text { Comunicações. Eles querem convencer a } \\
\text { sociedade que a programação televisiva já é } \\
\text { fiscalizada pelo Governo. }\end{array}$ & $\begin{array}{l}\text { As questões ainda não reguladas no Brasil, no que } \\
\text { tange às concessões, como veiculação de } \\
\text { precisam ser verificadas por um órgão regulador que } \\
\text { faça cumprir as determinações que estão na } \\
\text { Constituição. Para os movimentos sociais esse órgão } \\
\text { ainda não existe. }\end{array}$ \\
\hline
\end{tabular}

5.4.3 Acesso universal aos meios de comunicação e participação social

O acesso universal e a participação da sociedade na comunicação é um tema caro e central para os movimentos sociais que lutam pela democratização dos meios de comunicação. Porém, ele não teve a atenção adequada pela conferência. Os representantes do setor privado defendem, discursivamente, que são a favor deste acesso e de uma participação mais efetiva da sociedade na comunicação, mas não discutem as formas e nem o modelo para que isso ocorra. As entidades, por sua vez, ampliam em demasia a bandeira e não trabalham ponto a ponto como esta participação pode ser feita.

\footnotetext{
${ }^{270}$ Confecom termina aprovando 672 propostas para a área de comunicação, $\boldsymbol{O}$ Globo, 17/12/2009, p. 12.
} 
Um artigo do FNDC (2009) que foi publicado no Observatório da Imprensa mostra claramente a amplitude do tema:

\begin{abstract}
A universalização dos serviços de comunicação é tão importante para a sociedade quanto foi a expansão do sistema nacional de energia elétrica, por exemplo. Com a convergência tecnológica acelerada pela digitalização dos meios, o acesso às comunicações se tornou imprescindível a todos, para que estejam incluídos socialmente, e precisa estar inserido no princípio de bem público. Qualquer iniciativa que pretenda universalizar os serviços nessa área, do ponto de vista do FNDC, deve considerar um projeto estratégico nacional de digitalização. ${ }^{271}$
\end{abstract}

Essa categoria reuniu 16 unidades temáticas recolhidas nos três jornais e 30 nos dois sites analisados. E foi a que apresentou mais pontos de convergência de pensamento entre os dois lados. "O FNDC defende a necessidade de uma rede pública e única que garanta à população acesso universal aos meios, e a oferta de vídeo, voz e dados” (FNDC, 2009).

O Estado de S. Paulo também partilha da mesma opinião: “Cabe ao Estado prover e afiançar a democratização do sistema de comunicação e do acesso irrestrito aos conteúdos a todos os cidadãos" ${ }^{272}$. O Fórum participa da mesma ideia, mas o assunto continua vago: "Para tanto, as empresas privadas e o Governo precisam ter políticas efetivas para que essas novas redes de tecnologia possam chegar a todos os brasileiros. Esse é o desafio, por meio de um misto de redes privadas e públicas". ${ }^{273}$

A diferença entre os dois segmentos vai, naturalmente, para a prática. Na retórica, os dois lados comungam da mesma posição. O então secretário nacional de Articulação e representante da Secretaria-Geral da Presidência na Comissão Organizadora da Confecom, Gerson Almeida, argumentou

que o avanço democrático implica numa ampla liberdade de manifestação de todos os segmentos, sem que nenhum setor econômico monopolize a comunicação... É necessária uma regulamentação que garanta que todos os setores estejam articulados com preceitos de universalização e de responsabilidade com suas orientações. ${ }^{274}$

\footnotetext{
${ }^{271}$ Direito à informação, direito essencial. Disponível em: <www.observatoriodaimprensa.com.brEd.588>. Em $4 / 5 / 2010$.

${ }^{272}$ Controle versus democratização, artigo, O Estado de S. Paulo, 14/12/2009.

${ }^{273}$ Propostas para a construção de uma comunicação democrática. FNDC, 7/12/2009.

${ }^{274}$ Propostas para a construção de uma comunicação democrática. FNDC, 7/12/2009.
} 
$\mathrm{Na}$ visão de Gerson Almeida, para uma política de desenvolvimento da cultura é preciso um projeto nacional de desenvolvimento e inclusão social.

Precisamos ter de fato um processo de inclusão não só em termos econômicos, mas como uma política de sociedade, e o Estado é parte disso para universalizar o acesso à informação, ao cinema, às bibliotecas, às escolas e universidades de boa qualidade. Enfim, é um conjunto de luta contra exclusões de toda ordem. ${ }^{275}$

É importante, segundo Almeida (2009), no que diz respeito à informação e à opinião pública, que seja possível o maior número de veículos e de fontes de produção. ${ }^{276}$

O Globo, por sua vez, dá sinais de consenso neste quesito. Reconhece que esse acesso aos meios de comunicação é um grande avanço para a sociedade e o considera fundamental: “criar política de massificação de TVs por assinatura e de universalização da banda larga para facilitar o uso da internet em todo o País, principalmente nas regiões distantes dos grandes centros". 277

A seguir, um quadro-síntese com a argumentação de cada um dos lados na categoria “Acesso universal/participação social":

Quadro 10 - Acesso universal/participação social/síntese

\begin{tabular}{|l|l|}
\hline \multicolumn{1}{|c|}{ Mídia tradicional } & \multicolumn{1}{|c|}{ Entidades sociais em defesa da democratização } \\
\hline $\begin{array}{l}\text { A sociedade e os cidadãos é que são os } \\
\text { grandes beneficiários da liberdade, que lhes } \\
\text { dá acesso a todas as informações, mas isso } \\
\text { deve ser feito sem controles ou tutelas. }\end{array}$ & $\begin{array}{l}\text { Ao Estado cabe prover e afiançar a democratização do } \\
\text { sistema de comunicação e garantir o acesso irrestrito a } \\
\text { todos os conteúdos, por todos os cidadãos. }\end{array}$ \\
\hline $\begin{array}{l}\text { As entidades sociais querem de volta } \\
\text { soluções ultrapassadas que já deram errado, } \\
\text { como a recriação da Embrafilme. São } \\
\text { contra a democratização da verba } \\
\text { publicitária federal. }\end{array}$ & $\begin{array}{l}\text { Cabe ao Estado criar uma política de massificação de } \\
\text { TVs por assinatura e de universalização da banda } \\
\text { larga, para facilitar o uso da internet em todo o País, } \\
\text { principalmente nas regiões distantes dos grandes } \\
\text { jornais insistiram que a produção } \\
\text { nacional já é muito rica e estimulada. A recriação da Embrafilme chegou a ser } \\
\text { cogitada }\end{array}$ \\
\hline \multicolumn{1}{|l|}{$\begin{array}{l}\text { Incentivo à regionalização de conteúdo e } \\
\text { descriminalização das rádios comunitárias. }\end{array}$} \\
\hline $\begin{array}{l}\text { Os especialistas da área acreditam que o Brasil tem } \\
\text { rica produção regional e independente, o que falta é } \\
\text { uma estrutura eficiente de distribuição. }\end{array}$ \\
\hline
\end{tabular}

\footnotetext{
${ }^{275}$ Propostas para a construção de uma comunicação democrática. FNDC, 7/12/2009.

${ }^{276}$ Mídias com alcance regional e local se completam e ambas são importantes, FNDC, 7/12/2009.

${ }^{277}$ Confecom aprova medidas restritivas ao jornalismo, O Globo, 18/12/2009, p. 9.
} 


\subsubsection{Pluralidade midiática}

Foram extraídos do corpus apenas 11 unidades temáticas dos jornais e 21 dos sites. As proposições mais polêmicas que envolviam a pluralidade dos meios de comunicação não foram adiante. Em face do que foi manifestado pela cobertura, surge a percepção de que essas questões foram pouco trabalhadas pelos sites, por serem muito de difícil aprovação, e os jornais tradicionais também acham que essa pluralidade já existe. As mais polêmicas não avançaram, como uma obrigatoriedade de espaço para as entidades sociais na transmissão de programação pela televisão, algo parecido com o chamado "direito de antena" dos partidos político. Essas questões, de certa forma, foram também tratadas naquelas de acesso universal, da categoria anterior, pois são conteúdos transversais e que, naturalmente, se misturam.

A impressão que ficou dos argumentos presentes nas declarações dos representantes da mídia tradicional é que no Brasil já existe uma grande pluralidade, sendo considerado assunto superado. Parece até ironia o que diz o vice-presidente da Band e representante da Associação Brasileira de Radiodifusores (Abra), Walter Ceneviva (2009), quando abordou um dos temas da pluralidade dos meios:

houve uma proposta que, felizmente, foi rejeitada, que proibia que programas policiais fossem transmitidos. Não são cinco ou dez burocratas em Brasília, organizados em um Conselho, que devem dizer o que a gente pode ver ou não. Isso quem decide somos nós, afirmou Ceneviva. (FNDC, 2009).

Outra derrota dos movimentos sociais foi a proposta que "previa a obrigação de que emissoras veiculassem inserções de ONGs e movimentos sociais em horários de programações, como é feito com partidos políticos" (FNDC, 2009). O diretor da Abert, Luís Roberto Antonik, também criticou uma proposta aprovada pela Confecom que, se regulada, teria que ser muito fiscalizada para funcionar com eficiência. "A que obriga as emissoras de rádio e TVs abertas, e por assinatura, a reservar 10\% das horas veiculadas de programação para conteúdo educativo, cultura, informação e artes" (FNDC, 2009).

Proposições mais objetivas não avançaram e ainda foram desqualificadas pelo jornal $O$ Globo com o argumento de que os movimentos querem verbas para investimento na produção cultural, mas esse pleito esconde o interesse em criar entidades que se transformam em cabides de emprego para a militância. É assim que o setor privado de mídia via a Embrafilme, citada como exemplo:

Do lado da sociedade, com apoio da União, há forte pressão para o favorecimento de TVs comunitárias e veículos de pequeno porte, por 
exemplo, com a destinação obrigatória de um terço da verba publicitária oficial. A necessidade de incentivo à regionalização do conteúdo veiculado pela mídia nacional aparece em teses como a recriação da Embrafilme. ${ }^{278}$

Em editorial, o jornal $O$ Estado de $S$. Paulo segue a mesma linha de argumentação do jornal $O$ Globo: a de que a defesa das entidades sociais de uma mídia mais plural com mais espaço e oportunidades esconde a intenção de ampliar o espaço para que os militantes ligados ao movimento tenham mais empregos e influência. Enquanto as entidades alegam que a mídia privada não vai abrir mão da hegemonia que detém sobre a sociedade, para não ver reduzido o seu poder de influência junto ao poder e às elites dominantes. É um jogo de palavras que desvela a uma luta de poder por cada espaço no cenário midiático.

Em meio a um sem-número de lugares-comuns politicamente corretos, alguns participantes da $1^{\text {a }}$ Confecom também tentaram defender suas "boquinhas". Eles querem que o Governo destine parte da publicidade oficial para veículos alternativos comunitários e, na velha tradição dos cabides de emprego, reivindicam a expansão do sistema público de comunicação e a recriação das delegacias do Ministério das Comunicações nos Estados. ${ }^{279}$

A seguir, um quadro-síntese com a argumentação de cada um dos lados na categoria "Pluralidade midiática":

Quadro 11 - Pluralidade midiática/síntese

\begin{tabular}{|l|l|}
\hline \multicolumn{1}{|c|}{ Mídia tradicional } & \multicolumn{1}{|c|}{$\begin{array}{c}\text { Entidades sociais em defesa da } \\
\text { democratização }\end{array}$} \\
\hline $\begin{array}{l}\text { Para o jornal O Estado de S. Paulo, "quem } \\
\text { promove diversidade de vozes não é o Estado - é a } \\
\text { sociedade. Ao Estado cabe apenas zelar pela } \\
\text { vigência do regime que preserva a liberdade". }\end{array}$ & $\begin{array}{l}\text { O País tem que criar uma política de } \\
\text { desenvolvimento cultural para o Brasil, } \\
\text { exercer sua soberania, respeitando a a } \\
\text { diversidade cultural, que preveja a inclusão } \\
\text { social e o estímulo à produção regional. }\end{array}$ \\
\hline $\begin{array}{l}\text { A mídia privada também defende, retoricamente, } \\
\text { que a cultura regional seja estimulada, assim como } \\
\text { a produção independente, desde que não afete a } \\
\text { distribuição de verbas publicitárias federais e que } \\
\text { não seja criado nenhum novo órgão público para } \\
\text { cuidar dessa demanda, como quando existia a a } \\
\text { Embrafilme. }\end{array}$ & $\begin{array}{l}\text { Valorização da produção audiovisual cultural } \\
\text { de outras regiões do País, além do eixo } \\
\text { Rio/São Paulo. Além da garantia de } \\
\text { distribuição de conteúdo e produção regional. }\end{array}$ \\
\hline $\begin{array}{l}\text { Apesar de defender a pluralidade, os jornais são } \\
\text { contra qualquer definição de cota que garanta } \\
\text { espaço para a pluralidade de conteúdos ou cotas } \\
\text { para a produção nacional. }\end{array}$ & $\begin{array}{l}\text { Ampliação da liberdade de manifestação de } \\
\text { todos os segmentos da sociedade, com espaço } \\
\text { reservado na mídia tradicional. }\end{array}$ \\
\hline \multicolumn{2}{|c|}{$\begin{array}{l}\text { As entidades sociais se sentiram vitoriosas } \\
\text { com relação à oferta de serviço de internet em } \\
\text { banda larga, e que ele seja prestado em regime } \\
\text { público com metas de universalização. }\end{array}$} \\
\hline
\end{tabular}

\footnotetext{
${ }^{278}$ Propostas desagradam entidades, O Globo, 18/12/2009.

${ }^{279}$ O saldo da Confecom, editorial, O Estado de S. Paulo, 21/12/2009, p. 4.
} 


\subsubsection{Mudanças tecnológicas}

Muitas das questões de cunho tecnológico, foram recusadas pelo instrumento da “questão sensível”, a pesquisa optou por resumi-las numa grande rubrica denominada "mudanças tecnológicas", uma vez que foi nesse campo que as "questões sensíveis" mais foram levantadas. Este foi um tema que, realmente, causou polêmica no encontro. Essa polêmica surgiu muito em função da evolução da tecnologia, e pelo fato de que os embates burocráticos e ideológicos estão muito defasados em face da realidade promovida pela revolução tecnológica em curso. Além disso, a briga da divisão do espectro eletromagnético é muito feroz, desde os tempos da Constituinte, e ainda persiste.

O tema só não gerou mais discussões por ser muito complexo e não ter sido dominado pela maioria dos delegados. Foram coletados somente quatro fragmentos dos jornais e 11 dos sites. As propostas que mais interessavam aos movimentos, como a reativação da Telebrás, não foi aprovada por puro capricho dos delegados, uma vez que contava com a simpatia de parte do setor empresarial privado. $\mathrm{Na}$ hora das votações, um lado exigiu o quórum qualificado, usou o mecanismo da "questão sensível" e a proposição foi derrubada. A proposta de reativação da Telebrás, apesar de rejeitada, foi uma das raras propostas adotadas pelo então presidente Lula em 2010.

Para organizar os serviços digitais e o gerenciamento da infraestrutura de redes nas tecnologias existentes e nas que, porventura, venham a surgir, o Fórum sugeriu a criação da Organização Nacional de Serviços Digitais (ONSD). Seguindo o conceito de rede pública e única, a ONSD teria a função de evitar o desperdício de recursos públicos e privados na implantação de infraestruturas, impedindo o aumento dos custos dos serviços a serem repassados aos usuários. ${ }^{280}$

Mas essa ideia não prosperou como desejavam as entidades do movimento. Segundo Leonardi, diretor de Políticas Públicas do Google no Brasil, "não adianta nada termos um Marco Civil da Internet e não ter infraestrutura capaz de lidar com seu crescimento no País" ${ }^{281}$. E complementou: "As pessoas não enxergam que a ausência de definição de responsabilidade atrapalha a inovação e o crescimento da internet no Brasil”.

\footnotetext{
${ }^{280}$ FNDC defende reativação da Telebrás. Disponível em: <http://fndc.org.br/clipping/vivo-defendereativacao-da-telebras-mas-no-modelo-publico-privado-492309/>.

${ }^{281}$ O Marco Civil foi aprovado pelo Congresso Nacional e sancionado pela presidente Dilma em 6 de maio de 2014.
} 
Matéria do jornal Folha de S. Paulo, explica porque a proposta de revitalização da Telebrás não foi aprovada:

a Telebrasil e a Abra fizeram um pacto para apoiar as propostas de interesse mútuo e exigir quórum qualificado nas votações contrárias aos seus interesses. Assim, vetaram duas propostas do meio sindical, a revitalização da Telebrás e a separação da infraestrutura de redes das telefônicas, em empresa independente, para estimular a competição. ${ }^{282}$

E em contrapartida, para dar continuidade à competição estéril criada entre os dois lados, os representantes das entidades sociais enfrentaram o setor privado, sem levar em conta o mérito das propostas. "Os civis derrubaram a proposta em que o setor empresarial exigia a multiprogramação na TV digital aberta. A sociedade civil defendeu que a aprovação dessa sugestão aumentaria o monopólio e rejeitou a proposta"283. Entre as propostas sem consenso e que foram rejeitadas, está a que cria o Plano Nacional de Banda Larga, com a adesão do setor privado. "A proposta, que segue na linha de uma política já apresentada pelo Governo, era uma reivindicação da Associação Brasileira de Telecomunicações (Telebrasil)". ${ }^{284}$

Foi notório, durante a Confecom, o espaço que os representantes das telecomunicações ganharam nos grupos de trabalho e também nas votações da plenária final. Mas foi o jornal Folha de S. Paulo que deu o maior destaque para o surgimento desse novo segmento, como um importante ator no novo cenário midiático de luta por espaços. No dia 17 de dezembro de 2009, publicou matéria dando destaque ao poder das empresas de telecomunicações, com o seguinte título: Teles têm maior poder de voto em Conferência de Comunicação.

$\mathrm{Na}$ matéria, o jornal afirma que "as companhias telefônicas aproveitaram o esvaziamento da $1^{\mathrm{a}}$ Conferência Nacional de Comunicação, convocada pelo presidente Lula, para colher dividendos políticos tanto do Governo como do meio sindical”. Esse esvaziamento deve-se à ausência das seis entidades representativas do empresariado, que não participaram do evento. Em face dessa ausência, a telefonia teve direito a um número maior de votos. O jornal explica: "a telefonia tornou-se o segmento com maior representação na Conferência, com $26 \%$ do total de delegados com poder de voto". Os demais delegados da cota empresarial foram indicados pelos grupos Bandeirantes e Rede TV e também por algumas empresas regionais presentes. A Folha observou que "no primeiro dia de trabalho, as

\footnotetext{
${ }^{282}$ Sindicatos rejeitam redução de impostos sobre banda larga, Folha de S. Paulo, 18/12/2009, p. A13.

283 Setor empresarial trava embates com a sociedade civil na Confecom. Disponível em: <http://fndc.org.br/clipping/setor-empresarial-trava-embates-com-a-sociedade-civil-na-confecom-469682/> .

284 Setor empresarial trava embates com a sociedade civil na Confecom. Disponível em: <http://fndc.org.br/clipping/setor-empresarial-trava-embates-com-a-sociedade-civil-na-confecom-469682/>.
} 
teles, campeãs de reclamações de consumidores, foram chamadas de "empresariado progressista" por oradores do movimento sindical".

Foi natural o avanço dos representantes das empresas de telecomunicações, além de eles estarem em maior número no encontro. Os representantes dos movimentos sindicais viram nesse setor um possível aliado, uma vez que em várias discussões eles se posicionaram contra as decisões que agradariam as empresas de radiodifusão. Parece que o empresariado privado, que sempre foi um bloco hermeticamente fechado em discussões dessa natureza, começou a mostrar sinais de divisão, o que enfraqueceu todo o segmento.

Apesar de impasses de ordem tecnológica que marcaram as decisões, algumas questões avançaram. Um dos temas mais significativos e que criou polêmica entre os empresários e os movimentos sociais foi a questão da Banda Larga. De um lado, foi aprovada a decisão de que a banda larga tem que ser tratada como um serviço público e um direito fundamental do cidadão. O impasse veio depois. Nem o desejo dos empresários de que a iniciativa privada também estivesse incluída e nem a reativação da Telebrás, como queriam as entidades sociais foram atendidos. A realidade, que é soberana, resolveu o impasse: em 12 de maio de 2010 o Governo baixou o Decreto $n^{\circ} 7.175$, instituiu o Programa Nacional de Banda Larga (PNBL) e reativou a Telebrás. ${ }^{285} \mathrm{O}$ curioso é que o Governo colocou em prática, primeiro, uma proposta que não tinha sido aprovada pela Confecom, mas que era defendida pelas entidades sociais.

O que parecia desprovido de sentido teve sua lógica pelo sistema de votação estabelecido pela Conferência. Muitas vezes, um segmento derrubava a proposta do outro, para impedir que ela avançasse, arguindo o instrumento do "voto sensível". Isso acabou sendo usado pelos dois lados, mas foi muito criticado pelas entidades sociais. A coordenadora de Mobilização da Executiva do Fórum Nacional pela Democratização da Comunicação (FNDC), Roseli Goffman, explicou essa questão: "Ela lembrou que o "voto sensível" foi fator crucial para que a pauta em questão tivesse sido rejeitada na Plenária”. O estabelecimento desse tipo de voto para temas considerados sensíveis foi motivo de grande polêmica durante a elaboração do regimento.

A regra era que qualquer um dos setores representados na Confecom - Governo, empresas e sociedade civil - podiam pedir uma votação sensível o que, automaticamente, exigiria quórum qualificado de votantes para a aprovação da proposta, ou seja, $60 \%$ de apoio. Além disso, a proposta só poderia ser aprovada se houvesse ao menos um voto favorável de

\footnotetext{
${ }^{285}$ A Telebrás foi criada durante o regime militar, em julho de 1972. Em 1998, foi desativada pelo governo de Fernando Henrique Cardoso pelo processo de privatização e em 2010 reativada pelo então presidente Lula.
} 
cada um dos setores, mesmo que o número de apoiadores superasse os 60\%. Essa regra dificultou a aprovação de temas solicitados com "voto sensível". O uso do Fundo de Universalização dos Serviços de Telecomunicações (Fust) pela Telebrás foi um deles. Pautas de interesse das teles também foram rejeitadas com a utilização do mesmo método. Foi o caso das propostas de redução da carga tributária do setor, rejeitadas por conta da falta de apoio das entidades representativas da sociedade civil.

Durante as votações havia expressiva queda de braço a cada votação importante. Por exemplo, "os civis derrubaram a proposta em que o setor empresarial exigia a multiprogramação na TV digital aberta. A sociedade civil defendeu que a aprovação dessa sugestão aumentaria o monopólio e rejeitou a proposta" ${ }^{286}$. A seu favor, os empresários conseguiram derrubar várias propostas que estabeleciam cotas de programação e de espectro de comunicação. Foi rejeitado o item que garantia a redistribuição das concessões de rádio e TV em participação de 1/3 para o setor público, 1/3 para o setor privado e 1/3 para os canais do setor estatal.

O superintendente-executivo da Telebrasil, César Rômulo Silveira Neto, lembrou que uma das pautas da Confecom era o uso do Fust para a viabilização da Telebrás como gestora do programa de massificação de banda larga. "Essa proposta foi rejeitada pela Plenária da Confecom" ${ }^{287}$, lembrou o empresário ao comentar o decreto que criou o PNBL.

Diante do balanço das propostas aprovadas pelo Confecom, o Observatório da Imprensa avaliou que "a votação mostrou equilíbrio na representação entre os dois segmentos". Os empresários conseguiram retirar da proposta do documento final da Confecom a reativação da Telebrás e as entidades sociais também derrubaram uma proposta que era do setor, como a desoneração tributária ${ }^{288}$, e os empresários rejeitaram a proposta que recomendava afixação de cotas para a programação das emissoras de radiodifusão.

A questão do crescente poder das empresas de telecomunicações, na avaliação do então ministro da Secretaria de Comunicação da Presidência (Secom), Franklin Martins, teria que ter sido enfrentada pela Conferência, pois em entrevista concedida ${ }^{289}$ quase um ano

\footnotetext{
${ }^{286}$ Conferência propõe controle social da Comunicação.FNDC,18/12/2009

${ }^{287}$ Debate sobre a Confecom reacende polêmica sobre reativação da Telebrás. Disponível em: <http://www.teletime.com.br/10/06/2010/debate-sobre-confecom-reacende-polemica-sobre-reativacao-datelebras/tt/185498/news.aspx>.

${ }^{288}$ Essa rejeição à redução dos impostos foi uma das questões incoerentes da Confecom. O Brasil ocupa o terceiro lugar entre os países onde o custo das telecomunicações é mais elevado, abaixo apenas da Turquia e de Uganda. Os representantes das entidades sociais foram contra por achar que a ideia iria agradar apenas aos empresários, mas, na verdade, são os consumidores os mais afetados.

${ }^{289}$ Entrevista concedida ao Portal Vermelho, 10/11/2010. Disponível em: <http://www.vermelho.org.br/noticia _print.php?id_noticia=141248\&id_secao=6>. Acesso em: 29/9/2013.
} 
depois do evento, afirmou que "há uma disputa desigual entre os principais atores da comunicação no Brasil". Franklin revelou que "a radiodifusão faturou, em 2009, R\$ 13 bilhões, enquanto as telecomunicações faturaram R \$ 180 bilhões, e se não tiver uma nova pactuação, não é preciso ser nenhum gênio da raça para saber que só prevalece no mercado o mais forte" (MARTINS, 2013).

Parece ironia, ou até resistência pouco inteligente, por parte dos empresários da mídia tradicional, mas "os veículos tradicionais da grande mídia seriam os mais beneficiados com a regulação do setor, uma vez que a sanha das teles estará em xeque", comentou o ex-ministro da Secom. Segundo Martins (2013), "é necessário um marco regulatório que dê segurança aos agentes econômicos, continuidade de competição, inovação e que promova oferta de informação e conhecimento". Na realidade, os empresários também iriam se beneficiar dessa infraestrutura, assim como as entidades sociais, mas a questão da resistência do setor privado esconde o receio de que as teles realmente atropelem as empresas radiodifusoras e elas percam ainda mais espaço num novo cenário com novas tecnologias.

Martins acredita que como as telefônicas estão habituadas a operar em mercados regulados, quando quiserem "elas têm muito mais poder de fogo para convencer os facilmente influenciáveis deputados e senadores que os radiodifusores acreditam ter do seu lado. Caso não exista um marco regulatório definido, será a lei da selva” (MARTINS, 2013).

Logo depois do encerramento da Conferência havia uma nítida euforia nos artigos e matérias dos sites ligados aos movimentos sociais. Alguns com otimismo um pouco exagerado:

Agora, a Confecom dará respaldo ao presidente Lula para que, por meio de atos de Governo seja portaria, seja decreto ou regulamentação, muitas resoluções sejam transformadas em realidade. Aqui incluídas a criação do Operador Único de Rede nas mãos da EBC, a inclusão dos canais comunitários na TV digital em sinal aberto, a distribuição equitativa de concessões na era digital para os segmentos público, estatal e privado. ${ }^{290}$

Esse 'operador único' representa, na prática, a implantação de uma infraestrutura comum em todo o País, que atenda as emissoras públicas, não apenas a EBC, mas os canais do Legislativo, do Judiciário etc. Significa o grande compartilhamento de uma rede nacional.

A seguir, um quadro-síntese com a argumentação de cada um dos lados na categoria "Mudanças tecnológicas":

\footnotetext{
${ }^{290}$ Confecom: uma primeira vitória, uma nova etapa na longa luta. FNDC, 21/12/2009. Disponível em: <http://fndc.org.br/clipping/confecom-uma-primeira-vitoria-uma-nova-etapa-na-longa-luta-471167/>.
} 
Quadro 12 - Mudanças tecnológicas/síntese

\begin{tabular}{|l|l|}
\hline \multicolumn{1}{|c|}{ Mídia tradicional } & Entidades sociais em defesa da democratização \\
\hline $\begin{array}{l}\text { A Folha, assim como outros jornais, achou que } \\
\text { a Confecom usou a discussão do novo marco } \\
\text { regulatório para o futuro pensando nas novas } \\
\text { tecnologias de mídia como pretexto para que o } \\
\begin{array}{l}\text { atual mapa de propriedade pudesse ser } \\
\text { discutido. }\end{array}\end{array}$ & $\begin{array}{l}\text { larganizar os serviços digitais e o } \\
\text { terenciamento da infraestrutura de redes nas } \\
\text { defenderam a criação da Os entidades sociais } \\
\text { Serviços Digitais (ONSD), mas foi rejeitada. }\end{array}$ \\
\hline $\begin{array}{l}\text { As teles veem a proposta de uma operadora } \\
\text { estatal de banda larga como retrocesso. }\end{array}$ & $\begin{array}{l}\text { Para o FNDC não adianta termos um Marco Civil } \\
\text { da Internet sem infraestrutura capaz de lidar com } \\
\text { o crescimento da internet no País. }\end{array}$ \\
\hline $\begin{array}{l}\text { Os civis derrubaram a proposta em que o setor } \\
\text { empresarial exigia a multiprogramação na TV } \\
\text { digital aberta. }\end{array}$ & $\begin{array}{l}\text { As entidades argumentavam que pessoas não } \\
\text { enxergam que a ausência de definição de } \\
\text { responsabilidade atrapalha a inovação e o } \\
\text { crescimento da internet no Brasil. }\end{array}$ \\
\hline & $\begin{array}{l}\text { A sociedade civil defendeu que a } \\
\text { multiprogramação aumentaria o monopólio e } \\
\text { rejeitou a proposta. }\end{array}$ \\
\hline
\end{tabular}

\subsection{Por dentro das categorias temáticas - Uma síntese}

As categorias aqui criadas e apresentadas reuniram "unidades temáticas" que deram sentido ao objeto analisado. Seria como se essas unidades representassem a ponta do iceberg, e a sua reunião em categorias começasse a trazer uma maior compreensão sobre a análise e interpretação feita nesta pesquisa.

Para que essas unidades ganhassem o sentido buscado pelo trabalho, foi preciso buscar a apontar as formações discursivas que deram sentido aos enunciados identificados nos discursos relevantes construídos durante a Conferência Nacional de Comunicação. Essas formações, certamente, só podiam estar imersas na complexidade da evolução do contexto sócio-histórico e político em que a mídia brasileira se constituiu como tal. Foi na história recente do País, mais precisamente a partir da década de 1950, do século passado, que a pesquisadora foi garimpar esses enlaces.

E mais uma vez, fechando o foco, a busca se deu nas relações que se constituíram entre a mídia, o capital, a política, o poder e a sociedade brasileira. E, naturalmente, no discurso extraído dos atores que construíram essa trajetória e engendraram essas batalhas ao longo das últimas décadas. Essa busca foi guiada a partir dos conceitos discutidos no referencial teórico e a partir dos objetivos estabelecidos pelo estudo.

Após a ditadura, a grande imprensa passou por profundas transformações, sendo fortemente influenciada "pela ideia da notícia como produto destinado ao consumo" 
(MATOS, 2008, p. 300) e acabou por se consolidar como uma imprensa comercial de modelo anglo-americano, com foco no mercado e com forte caráter elitista.

O liberalismo econômico, de origem americana, que se seguiu ao fim da ditadura, foi fundamental para o fortalecimento da imprensa e até criado um emergente mercado de consumo,

a comercialização excessiva, no entanto, culminou na expansão da concentração da mídia, com o liberalismo econômico mostrando-se incapaz de produzir distribuição de renda, o que logo resultou na articulação de argumentos favoráveis a uma maior intervenção do Estado na economia. (MATOS, 2008, p. 304).

Para a pesquisa adentrar nos conteúdos selecionados, foi preciso observar o que foi feito pela mídia tradicional e pelos sites, antes do período de recorte. Essa observação e apreensão ajudaram a captar melhor o que foi mediado depois pelos dois lados, ou seja, além da análise e interpretação feita a partir do corpus, a pesquisa analisou o que foi chamado de “entorno do corpus". São produtos que foram coletados antes da realização da Confecom, nos jornais selecionados, e que foram importantes para compreender o posicionamento desses meios perante a Conferência.

Embora os dois discursos apresentados aqui - o da mídia tradicional e dos movimentos sociais - tenham emergido de um mesmo contexto caracterizado materialmente no cenário da $1^{\text {a }}$ Conferência Nacional de Comunicação, cada um deles trouxe consigo marcas ideológicas derivadas de suas respectivas formações discursivas. A noção "formação discursiva" aqui já mencionada - básica na Análise do Discurso - permitiu compreender o processo de produção de sentidos desencadeado por cada um dos lados. "O sentido não existe em si, mas é determinado pelas posições ideológicas colocadas em jogo no processo sóciohistórico em que as palavras são produzidas". (ORLANDI, 2002, p. 42).

Foi a partir do recorte seletivo dos sentidos manifestos nos textos selecionados, denominados corpus, é que as categorias semânticas foram criadas. Cada sentido manifesto foi colocado lado a lado, nas tabelas que foram apresentadas (cuja íntegra está em anexo), e evidenciam como "as palavras mudam de sentido segundo as posições daqueles que as empregam" (ORLANDI, 2002). Essas posições se inscrevem, por sua vez, em determinada conjuntura sócio histórica que nos permite perceber o que pode ser dito e o que não pode, assim como o traço ideológico de cada um dos enunciados, desvelando sujeito que o carrega.

"Não há discurso sem sujeito e não há sujeito sem ideologia" (ORLANDI, 2002) cujo aparato teórico serve de fio condutor para a interpretação e compreensão dos dados desta 
pesquisa. A ideologia é parte constitutiva do sujeito e dos sentidos. Segundo Maingueneau (2002),

o discurso só é discurso enquanto remete a um sujeito, um EU que se coloca como fonte de referências pessoais, temporais, espaciais e, ao mesmo tempo, indica que atitude está tomando em relação àquilo que se diz e a relação com seu interlocutor ou coenunciador. (MAINGUENEAU, 2002, p. 52).

A singularidade dos discursos construídos antes e durante a Confecom, aqui analisados, sugere que é possível compreender o enunciado exatamente porque este legitima um lugar de fala e um posicionamento do sujeito enquanto "fiador da veracidade" do discurso que carrega. "Todo discurso, por sua manifestação mesma, pretende convencer instituindo a cena de enunciação que o legitima" (MAINGUENEAU, 2002). No caso em análise, a cena de enunciação refletiu, de fato, um duelo de argumentos em que cada um dos lados, expostos pelo aparato midiático em questão, tentou convencer seu público ou alcançar públicos outros. Enunciar, no caso em análise, não significa tão somente “expressar ideias", mas tentar convencer, construir e legitimar um argumento hegemônico. "Os discursos, pois, indiciam as intenções dos enunciadores." (SOUSA, 2004, p. 63).

Para Orlandi (2005), que tão bem incorporou e traduziu esses pressupostos da Análise do Discurso no contexto dos estudos brasileiros, o lugar do pesquisador, orientado pela AD, não é o da indiferença ou da prática ideológica, mas “o da interpretação".

A construção desse dispositivo (teórico) resulta na alteração da posição do leitor para o lugar construído pelo analista. Lugar em que se mostra a alteridade do cientista, a leitura outra que ele pode produzir... Por isso é que dizemos que o analista do discurso, à diferença do hermeneuta, não interpreta, ele trabalha (n)os limites da interpretação. Ele não se coloca fora da história, do simbólico ou da ideologia. Ele se coloca em uma posição deslocada que lhe permite contemplar o processo de produção de sentidos em suas condições. (ORLANDI, 2005, p. 61). 


\section{CONCLUSÃO}

O embate discursivo entre empresários do segmento de mídia e movimentos sociais por meio de jornais e sites - mostrou que os empresários do setor privado de mídia e as entidades que representam o movimento social pela defesa da democratização dos meios, não chegaram a um consenso que permitisse a construção de um novo marco regulatório para o país. Não houve acordo em questões-chave da regulação como a liberdade de imprensa e expressão, o controle social da mídia, o acompanhamento e fiscalização da produção jornalística e o fim das concessões e outorgas por conveniência e acordos políticos.

Esta falta de entendimento, naturalmente, paralisa ações do Congresso Nacional ou do próprio Governo no sentido de encaminhar propostas que avancem no sentido desta regulação. Cada um desses momentos ou acontecimentos que permearam a recente história dos meios - que nessa análise se estendeu até a realização da Conferência - deixou claro, ainda, que o Governo tem dado demonstrações de paralisia ou de descaso com a questão da pluralidade dos meios de comunicação e com o controle da mídia. A realização da Confecom, todavia, foi positiva nesse sentido, pois reascendeu o debate - que deve ser permanente, mas por outro lado mostrou que cada um dos lados usou a oportunidade da Conferência - que deu a voz a todos os lados da contenda - para reforçar suas posições e princípios, sem contudo abrir novos espaços para negociações e acertos mais flexíveis.

As reações dos movimentos sociais quanto ao atendimento das exigências dos empresários, de modo que a Confecom fosse viabilizada teve um preço. Os movimentos aceitaram as alterações no quórum para que os poucos empresários que haviam ficado permanecessem, e a Conferência, enfim, pudesse acontecer. E ela aconteceu. Se não houvesse nenhuma representatividade empresarial a Conferência, com certeza, perderia a sua legitimidade. Os empresários, portanto, saíram com a reputação elevada, pois aceitaram sentar à mesa de negociações, e os movimentos sociais se sentiram usados neste cenário de aparente acordo e consenso. Esta percepção foi obtida pela reação das entidades que eram contrárias às concessões feitas aos empresários, como a Abraço e parte do Coletivo Intervozes.

Depois que tudo acabou, os donos de jornal - através de seus editorias e artigos revelaram, de fato, o que pensavam sobre a Confecom e como foram contrários aos entendimentos acertados e votados pelos delegados. Apenas esperaram que ela se encerrasse para que eles assumissem a postura que nunca abandonaram desde as negociações da Assembleia Nacional Constituinte. O Estado de S. Paulo publicou um editorial criticando a 
Confecom e alegando a mesma ameaça que marcou a posição do segmento desde a Constituinte de 1988. Para eles, as recomendações aprovadas foram ideologicamente enviesadas e se fossem transformadas em leis a liberdade de informação seria afetada e restringida. Para o jornal, o eventual controle público e social das atividades jornalísticas iria criar um obstáculos à ação da iniciativa privada no setor.

Esta reação do jornal corrobora a tese de que a Conferência foi utilizada para que os “donos da mídia” reposicionassem o mesmo discurso que foi construído há mais de 50 anos. E o jornal $O$ Estado de $S$. Paulo ainda sugere que o discurso do movimento social pela democracia dos meios também é o mesmo da década de 80. Os empresários alegaram que as entidades basearam o seu discurso nas velhas cartilhas da esquerda, que estão em desuso.

O jornal $O$ Globo foi na mesma direção. Em editorial publicado cinco dias após o encerramento da Confecom, o jornal lembra que quando parte dos empresários decidiu sair da Conferência eles já sabiam que o resultado seria desastroso e que as proposições aprovadas iriam contra a liberdade de imprensa e de expressão - nessa ordem - e que o desejo do Governo era o de intervir nas redações e criar obstáculos à ação da iniciativa privada.

Já a Abra usou o espaço para se confrontar com a Rede Globo e por isso defendeu que outras vozes tenham espaço, sugerindo que seria contra os monopólios. O vice-presidente executivo do Grupo Bandeirantes e representante da Abra, Walter Ceneviva, espera que as propostas consensuais em torno da pluralidade de conteúdo influenciem o Congresso Nacional. Agora ele defende que não se pode ter um mesmo grupo gerando e monopolizando a distribuição de conteúdo, e fechando a porta para os concorrentes Durante os debates a Abra se sentiu fortalecida com a ausência da Abert, que traria o posicionamento da Rede Globo.

A realização da conferência, que era um anseio das entidades que brigam pela democracia dos meios, contribuiu para um certo amadurecimento do debate entre as partes envolvidas. A Conferência, de certa maneira, evitou que o assunto ficasse restrito aos tradicionais representantes do setor midiático. Além disso, forçou, de alguma foram, um novo encontro amplificado dos dois segmentos, onde, praticamente, todos os temas ligados à comunicação foram tratados.

A Confecom, como foi largamente dito aqui, é resultado do pleito de movimentos sociais que mostraram engajamento neste debate, mas os compromissos acordados deixaram claro que o assunto não está pacificado e que questões antigas e urgentes precisam ser tratadas 
e reguladas. Ficou claro também que qualquer decisão a ser tomada para quebrar o monopólio dos meios de comunicação, ou democratizar a mídia, vai exigir muita luta e negociação, e que o setor empresarial está agarrado a velhos temores, reatualizados em 2009.

O crescente movimento deflagrado ao longo dessa recente história dos meios no Brasil deixou claro que novos atores fazem parte da arena de discussões e que a sociedade não está totalmente alheia ao que, até então, era definido em gabinetes fechados ao arrepio da lei ou da sociedade, mas isso graças mais à internet do que aos movimentos sociais.

O que veio contribuir para que a sociedade não fique de fora em uma discussão tão importante como essa, é, sem dúvida o aparato de participação oferecido pela internet. Quando estes representantes das entidades sociais e os empresários se reunirem novamente, o saldo intangível da Conferência, certamente, será lembrado, principalmente porque apesar das dificuldades e intransigências dos dois lados o encontro mostrou que é possível sentar junto, estabelecer um regimento e discutir o assunto que, a cada dia que passa, se altera em função do que a tecnologia está possibilitando. Caso a legislação e os acordos não se antecipem, muitas questões serão atropeladas pela Internet, especialmente com relação ao acesso à informação e à produção de conteúdos.

Com relação à cobertura do evento e ao discurso que cada lado manifestou, é importante frisar que tanto nos jornais como nos sites ficou clara a intencionalidade de cada órgão ao defender suas posições perante seus leitores. Não havia matéria isenta. Não só os sites, onde seria natural, mas também nos jornais foi possível observar que a cobertura foi ideológica, na medida em que, boa parte das matérias coadunava com o ponto de vista empresarial do dono do jornal, e muitas vezes, encobria posições contrárias aos interesses da sociedade. Os princípios de equilíbrio e objetividade com relação à informação, que devem ser respeitados, foram deixados de lado em variadas situações.

Foi possível identificar que cada um dos lados falou com seu público. Foi como se cada um tivesse, de fato, um contrato de leitura com seus leitores e usuários e que cada um falasse a linguagem que cada um esperava ouvir. Os sites, com raras exceções, pareciam estar falando o tempo todo com sua militância. Os jornais, em alguns momentos, supunham estar falando com um público sem acesso a outros meios de informação.

Os sites, em geral, optaram por matérias argumentativas e por artigos que reforçavam a posição do site. Os jornais, do mesmo modo, defendiam suas posições. As matérias, quando eram apenas noticiosas, vinham carregadas de adjetivação e clara tomada de posição. Os jornais usaram e abusaram de fontes não identificadas e, quase sempre, colocavam nessas 
fontes suas preocupações e pontos de vista. Também trouxeram artigos e editoriais com fortes críticas à realização da Confecom.

Os sites também erraram com a adoção de uma linguagem antiquada e muito politizada, que parecia o tempo todo um diálogo entre os pares, entre amigos e em meio às próprias trincheiras. Era um diálogo "entre” e não "para”. Não havia preocupação com o leitor eventual nem com o objetivo de conquistar novos leitores ou novas adesões à bandeira do novo marco. Os jornais, da mesma forma, buscaram reforçar seus argumentos junto aos leitores, como se o assunto fosse de domínio do público-leitor e feito apenas um trabalho de coerção consentida. As matérias se configuravam mais como reforço de posições, especialmente quando se referiam ao risco da volta da censura aos meios de comunicação.

Mais ao final do encontro, os sites foram os que trouxeram mais matérias e artigos comemorando os resultados da Confecom e assinalando com a perspectiva de um consenso para a adoção de medidas concretas para a regulação dos meios de comunicação. Essa aparente euforia se deveu mais ao fato de a Conferência ter acontecido apesar da ausência da poderosa Rede Globo e sua entidade, a Abert. Este fato foi relembrado em vários artigos das entidades sociais.

Os jornais, por sua vez, alertaram para o risco de os resultados trazerem menos liberdade de imprensa, mas não houve aprofundamento nas matérias. O mais comum era a insistência no mesmo argumento, de que a fiscalização ou a criação de observatórios de mídia poderia trazer a censura prévia de volta.

Embora os poucos empresários que participaram tenham encerrado a Conferência apostando no diálogo e no entendimento, os editoriais dos jornais apontavam os riscos das propostas aprovadas para o bom funcionamento das empresas. Todavia, junto aos sites, nos quais essas declarações foram bem apresentadas, a opção pelo consenso ganhou força, mas os jornais tentaram minimizar qualquer proposta mais avançada, alegando que o Congresso Nacional não aprovaria nada que ameaçasse as liberdades democráticas, mais uma vez reiterando a "estratégia da confusão".

Os empresários, notadamente, deixam claro que o estabelecimento de qualquer marco regulatório vai reduzir a autonomia dos jornais e pode ensejar algum tipo de censura aos conteúdos. Eles alegam que a criação de algum tipo de controle social assusta a classe empresarial, que temem que a experiência da Argentina se repita no Brasil, com o controle excessivo de conteúdo e perseguição à imprensa.

Os jornais argumentam que a mídia já é fiscalizada pelo Ministério das Comunicações e que a autorregulação seria o sistema mais adequado de controle. Argumentam, ainda, que 
diante de abusos cometidos pela imprensa, a sociedade pode recorrer à Justiça para ter seus possíveis danos reparados. De acordo com os jornais, a propriedade de mais de uma mídia por uma mesma empresa é uma realidade irreversível e qualquer mudança na lei só poderia atingir novas situações. A alegação é o direito adquirido. Ignoram que as concessões de outorgas precisam ser fiscalizadas para serem renovadas.

Acreditam que a concessão de outorgas não vai mudar, pois o Congresso Nacional, que seria o responsável pela mudança, não tem interesse nesse tema, uma vez que muitos políticos são proprietários de jornais e de emissoras de rádio e TV. Com relação ao acesso da sociedade aos meios de comunicação com participação social, os donos da mídia argumentam que a sociedade já tem acesso a todas as informações disponíveis, e que não há censura.

As entidades civis não empresarias, que elaboraram o discurso do confronto nas questões mais relevantes, insistem que é fundamental para a democratização da mídia a regulamentação dos arts. 221, 222 e 223 da Constituição Federal. Só com a construção de um marco regulatório será possível criar mecanismos como o Conselho de Jornalismo para acompanhar e fiscalizar a mídia. Com relação aos possíveis danos que a imprensa pode provocar, o movimento argumenta que o Poder Judiciário não tem capacidade e agilidade para acompanhar os abusos cometidos pela mídia.

A oligopolização dos meios, em face da ausência de um marco regulatório, impede o acesso amplo e universal da sociedade a outros conteúdos e outras informações, o que afasta o princípio do direito humano à Comunicação. Só com um marco regulatório definido será possível dar espaço para a produção de conteúdos regionais e ampliar o acesso à informação e à cultura fora dos grandes centros.

Os debates na Conferência deixaram ainda mais claro que só um marco regulatório, bem construído e discutido, em conjunto com as diversas organizações representativas da heterogeneidade do País, poderá atender aos interesses da maioria da população Todavia, não foi apenas para constatar essa questão que a pesquisa foi feita, e não foi essa a intenção deste estudo, mas avaliar, discursivamente, qual o tamanho da distância entre esses dois lados, que dificulta tanto essa regulação. A pesquisa traz elementos que ajudam a compreender se esse grande vácuo que separa as duas posições é instransponível, como sugere a recente história brasileira sobre a evolução dos meios de comunicação, ou se há condições possíveis de aproximação desses interesses.

O fato de ter acontecido a Conferência, apesar de todos os impasses, sugere que ainda é possível dialogar, mas que a distância entre os dois lados para que o consenso seja alcançado é ainda muito grande. É porque não se trata apenas da informação, e sim do poder 
que está nela agregado. O grande conglomerado midiático, que certamente representa o gigante Golias da história, não irá se render aos apelos dos movimentos sociais porque se sente atingido por suas demandas, mas poderá fazê-lo se perceber que o equilíbrio de forças, que sempre pendeu para o lado mais forte, está sendo reconstruído em novas bases, em função da internet.

O setor privado já não é mais um bloco único e hermeticamente fechado em suas tradicionais posições. A entrada das empresas de telecomunicações desequilibrou essa balança e a irreversível revolução tecnológica vai apressar esse novo arranjo de forças, os parâmetros para a divisão do espectro eletromagnético e do mercado terão que ser revistos.

Não que as telecomunicações não existissem, mas elas passaram por profunda mutação, tendo sido ressignificadas na nova conjuntura tecnológica e de mercado que está se consolidando no País. Atualmente, as telecomunicações entraram na disputada zona de produção de conteúdo para televisão e o fizeram com capital financeiro extremamente superior às empresas de radiodifusão.

Além disso, a Abert se omitiu e com ela a TV Globo ficou eclipsada, em consequiência a Abra cresceu, o que fortaleceu o Grupo Bandeirantes como negociador do lado dos empresários. Esta movimentação e as mudanças provocadas pela tecnologia podem forçar a Rede Globo e outros grupos empresariais ao debate. Pode estar perto o momento em que o setor terá de abrir mão de certas prerrogativas para contemplar as urgências dos excluídos do sistema, porque estes encontraram outros canais de acesso que trouxeram o empoderamento que faltava para que a batalha trouxesse um novo reequilíbrio de forças.

A pesquisa não trouxe somente os argumentos dos dois lados, mas mostrou que a maioria deles expõe um setor privado conservador que ainda está escorado em um discurso retrógado, e até apelativo, e que repete o mesmo ideário da Constituinte de 1988. O medo de perder audiência, público, leitores e poder e ter que repartir parte do que detêm numa possível redução de concessões e outorgas, acaba prevalecendo. E os movimentos sociais, por sua vez, não atualizaram os seus discursos frente à essa sociedade mais conectada do que outrora. $\mathrm{O}$ cenário mudou em relação a 1988, novos atores estão em cena, a internet mexeu com todo o mercado de mídia, e é essa realidade que poderá provocar possíveis e necessárias mudanças.

Mesmo que o diálogo observado em muitos momentos durante a Conferência não tenha sido o ideal e tenha exposto entraves históricos, o encontro, pelo menos, provou que é possível reunir, no mesmo cenário, representantes de cada um dos segmentos. Todos os lados reconheceram que foi feita a Conferência “do possível” e que não há como avançar a não ser pela via do diálogo e que toda negociação implica perdas e ganhos. 
Por fim, este estudo concluiu que valeu a pena ir atrás do que foi publicado pela mídia acerca da Conferência. O mergulho analítico nos discursos criados pelos dois lados da disputa apresentou mais pontos de fraqueza do que de força do setor privado, mostrando que é possível pensar em novos estudos que aprofundem como a mídia tradicional vai lidar com esse novo cenário tecnológico e se as entidades sociais vão saber se apoderar com sabedoria do gigantesco arsenal oferecido pela rede mundial de computadores.

O estudo sugere que foi escrita mais uma página na longa história da luta pela democratização dos meios de comunicação e que a Confecom, mesmo sem ter produzido mudanças concretas no cenário midiático, contribuiu para uma melhor compreensão de cada um dos atores desse embate. E apesar das resistências e dificuldades, a mídia parou para discutir a própria mídia. Alguns atores foram para dentro da arena, outros assistiram de fora o embate, mas ainda assim se viram forçados a falar de si mesmos. 


\section{REFERÊNCIAS}

BAESSE, J. M. de S. A "voz das ruas" manifesta na seção carta de leitor: crítica da mídia, interatividade e "diálogo retardado". Dissertação (Mestrado) - Universidade de Brasília. Brasília, 2004.

BARBOSA, B.; MODÉ, G. A Sociedade ocupa a TV: o caso de direito de resposta e controle social da mídia. Intervozes - Coletivo Brasil de Comunicação Social, São Paulo, SP, 2007.

BAYMA, I. F. de C. O telefone social do príncipe. In: ALMEIDA FILHO, A.; BARROS, V. S. de C. (Org.). Novo manual de Ciência Política. São Paulo: Malheiros, 2007. p. 331-355.

BARDIN, L. Análise de conteúdo. Lisboa: Edições 70, 1970.

BENETTI, M. Análise do Discurso em jornalismo: estudo de vozes e sentidos. In: Metodologia de pesquisa em jornalismo. Petrópolis, RJ: Vozes, 2007. p. 107-121.

BOAVENTURA, E. M. Metodologia da pesquisa. São Paulo: Atlas, 2013.

BOBBIO, N. As ideologias e o poder em crise. Brasília: UnB, 1988.

BOBBIO, N. Estado, Governo, Sociedade, para uma teoria geral da política. São Paulo: Paz e Terra, 2012.

BOBBIO, N. O Futuro da democracia. São Paulo: Paz e Terra, 2011.

BRAIT, B.; SILVA, M. C. S. (Org.). Texto ou discurso? São Paulo: Contexto, 2012.

BOLAÑO, C. R. S.; BRITTOS, V. C. Espaço midiático e a ideologia do merchandising social da rede Globo: uma crítica na perspectiva da economia política da comunicação. In: ALMEIDA FILHO, A.; BARROS, V. S. de C. (Org.). Novo manual de Ciência Política. São Paulo: Malheiros, 2007. p. 83-98.

BRITTOS, V. C.; ROCHA, B. L.; NAZÁRIO, P. M. Comunicação, conferência e pauta de democratização. Comunicação \& Política, v. 29, p. 13-28, 2010.

BRITTES, J. G. Estudo comparativo sobre Políticas Públicas de comunicação na América Latina. In: CONGRESSO BRASILEIRO DE CIÊNCIAS DA COMUNICAÇÃO. Intercom - Sociedade Brasileira de Estudos Interdisciplinares da Comunicação, 2013.

CARVALHO, L. B. Os meios de comunicação, a censura e a regulação de conteúdo no Brasil: aspectos jurídicos e distinções conceituais. Revista de Direito, Estado e Telecomunicações, v. 4, $\mathrm{n}^{\circ}$ 1, p. 51-82, 2012.

CASTELLS, M. A sociedade em rede. A era da informação: economia, sociedade e cultura. Volume 1. São Paulo: Paz e Terra, 1999.

CASTELLS, M. O poder da identidade. A era da informação: economia, sociedade e cultura. Volume 2. São Paulo: Paz e Terra, 1999.

CASTELLS, M. A Galáxia da Internet: reflexões sobre a internet, os negócios e a sociedade. Rio de Janeiro: Jorge Zahar, 2003. 
CASTELLS, M. Inovação, Liberdade e Poder na Era da Informação. In: MORAES, D. de. (Org.). Sociedade Midiatizada. Rio de Janeiro: Mauad, 2006. p. 225-231.

CASTELlS, M. Comunicacion y Poder. Madri, Espanha: Alianza Editorial, 2009.

CASTELLS, M. Redes de indignação e esperança. Rio de Janeiro: Zahar, 2013.

CHARAUDEAU, P. A linguagem e o discurso. São Paulo: Contexto, 2008.

CHAUÍ, M. Simulacro e poder: uma análise da mídia. São Paulo: Fundação Perseu Abramo, 2006.

SILVA, N. C. Hegemonia, estado e sociedade em Gramsci. Revista Saber Acadêmico, São Paulo, Uniesp, p. 31-37, 2011.

CORONEL, A. Disposições técnico-discursivas e cidadania em telejornais. In: FERREIRA, J.; VIZER, E. (Org.). Mídias e movimentos sociais. São Paulo: Paulus, 2007. p. 167-199.

CORREIA, J. C. Novos movimentos sociais e transformações no modelo de análises das mídias. In: FERREIRA, J.; VIZER,E. (Org.). Mídias e movimentos sociais. São Paulo: Paulus, 2007. p. 54-85.

COSTA, C. T. Ética, jornalismo e nova mídia. Rio de Janeiro: Jorge Zahar, 2009.

COUTINHO, E. G. (Org.). Comunicação e contra-hegemonia. Rio de janeiro: UFRJ, 2008.

COUTINHO, C. N. Fontes do pensamento político: Gramsci. Porto Alegre: L \& PM, 1981.

COUTINHO, C. N. Gramsci: um estudo sobre o seu pensamento político. Rio de Janeiro: Civilização Brasileira, 1999.

COUTINHO, C. N. A democracia como valor universal e outros ensaios. Rio de Janeiro: Salamandra, 1984.

COUTINHO, C. N. Gramsci: um estudo sobre seu pensamento político. Rio de Janeiro: Campus, 1992.

DANTAS, M. Resultados da $1^{\text {a }}$ Confecom: uma avaliação preliminar. In: ENCONTRO DA COMPÓS, 18, 2010 . Artigo apresentado ao GT Economia Política e Políticas de Comunicação, PUC-MG, junho de 2010.

DANTAS, M. Confecom: sociedade venceu, Abert e ANJ perderam. In: ULEPICC Brasil, 13/1/2010. Acesso em: 16 jun. 2010. Disponível em: $<$ http://www.ulepicc.org.br/interna.php?c=138\&ct=1169>.

DANTAS, R. Ideologia, hegemonia e contra-hegemonia. In: Comunicação e contrahegemonia. Rio de Janeiro:UFRJ, 2008.

DUARTE, L. G. É pagar para ver: a TV por assinatura em foco. São Paulo: Summus, 2005. FEITOSA, E. Estado e Sociedade Civil em Gramsci: entre coerção e consentimento. In: AlMEIDA FILHO, A.; BARROS, V. S. de C. (Org.). Novo manual de Ciência Política. São Paulo: Malheiros, 2007. p. 367- 403. 
FILHO PIMENTEL, E.; VASCONCELOS, E. P. Foucault: da Microfísica à Biopolítica. In: ALMEIDA FILHO, A.; BARROS, V. S. de C. (Org.). Novo manual de Ciência Política. São Paulo: Malheiros, 2007. p. 446- 459.

FERNANDES, R. C. Privado, porém público: o terceiro setor na América Latina. $2^{\mathrm{a}}$ ed., Rio de Janeiro: Relume-Dumará, 1994.

FERREIRA, J. Notícias sobre as ONGs: uma conjuntura aberta pelos dispositivos midiáticos na web. In: FERREIRA, J.; VIZER, E. (Org.). Mídias e movimentos sociais. São Paulo: Paulus, 2007. p. 133-148.

FORNAZARI, F. K. Reforma do Estado e Agências Reguladoras: o caso Ancine e Ancinav. In: 30 ENCONTRO DA ANPAD, 2006.

FOUCAULT, M. Microfísica do poder. Rio de Janeiro: Graal, 1979.

GASPARI, E. A ditadura escancarada. São Paulo: Companhia das Letras, 2002.

GOHN, M. da G. Novas teorias dos movimentos sociais. São Paulo: Loyola, 2012.

GOHN, M. da G. Sociedade Civil no Brasil: movimentos sociais e ONGs. p. 140-150, 2004. (Redalyc Sistema de Información Científica, n 20)

GOHN, M. da G. Movimentos sociais no início do século XXI. Petrópolis, RJ: Vozes, 2011.

GOHN, M. da G. O protagonismo da sociedade civil. São Paulo: Cortez, 2008.

GÓMES, G. O. Comunicação Social e Mudança Tecnológica: um cenário de múltiplos desordenamentos. In: MORAES, D. de (Org.). Sociedade midiatizada. Rio de Janeiro: Mauad, 2006. p. 81-98.

GREGOLIN, M. R. AD: Descrever - Interpretar acontecimentos cuja materialidade funde linguagem e história. In: NAVARRO, P. (Org.). Estudos do texto e do discurso: mapeando conceitos e métodos. São Carlos: Claraluz, 2006, p. 19-34.

GRUPPI, L. O conceito de hegemonia em Gramsci. Rio de Janeiro: Graal, 1978.

GUARESCHI, P. O direito humano à comunicação - pela democratização da mídia. Petrópolis, RJ: Vozes, 2013.

GUIMARÃES, J.; LIMA, V. A. (Org.). Liberdade de expressão - as várias faces de um desafio. São Paulo: Paulus, 2013.

HABERMAS, J. Mudança estrutural da esfera pública. Rio de Janeiro: Tempo Brasileiro, 1984.

HAJE, L. Comunicação, esfera pública e poder. In: RAMOS, M. C.; SANTOS, S. dos (Org.). Políticas de Comunicação - buscas teóricas e práticas. São Paulo: Paulus, 2007. p. 128147.

HERMIDA, J. F. Socialismo e Ciência da História em Karl Marx. In: ALMEIDA FILHO, A.; BARRos, V. S. de C. (Org.). Novo manual de Ciência Política. São Paulo: Malheiros, 2007. p. 305-338. 
JAMBEIRO, O. A re-configuração do ambiente regulado das comunicações na sociedade da informação. In: RAMOS, M. C.; SANTOS, S. dos (Org.). Políticas de Comunicação. São Paulo: Paulus, 2007. p. 99-125.

KLEIN, O. J. Dispositivos telejornalísticos em rede. In: FERREIRA, J.; VIZER, E. (Org.). Mídias e movimentos sociais. São Paulo: Paulus, 2007. p. 149-165.

LARA, G. Liberdade de expressão versus direito à comunicação: a regulação da comunicação audiovisual na Argentina. Revista de Direito e Telecomunicações, v. 4, no 1, p. 137-172, 2012.

LARA, G. Liberdade de expressão versus direito à comunicação: a regulação da comunicação audiovisual na Argentina. Tese (Mestrado) - Faculdade de Comunicação. Universidade de Brasília. Brasília, 2011.

LAVILlE, C.; DIONNE, J. A construção do saber. Porto Alegre: Ed. Artes Médicas Sul, 1999.

LEAL FILHO, L. L. Desafios da Comunicação para a Cidadania. In: Encontro ESTADUAL DE JORNALISTAS EM ASSESSORIA DE COMUNICAÇÃO DE MINAS GERAIS, 2007. Paper.

LIMA, V. A. Mídia teoria e política. São Paulo: Fundação Perseu Abramo, 2001.

LIMA, V. A. Liberdade de expressão versus liberdade de imprensa. São Paulo: 2010.

LIMA, V. A.; KUCINSKI, B. Diálogos da perplexidade. São Paulo: Fundação Perseu Abramo, 2009.

LIMA, V. A. Os midia e o cenário da representação política. Lua Nova: Revista de Cultura e Política, dez. 1996. Disponível em: <http://dx.doi.org/10.1590/S010264451996000200012>.

LINS, B. F. E. Elementos da Legislação de telecomunicações, informática e comunicação social. Nota Técnica. Brasília: Câmara dos Deputados, Comissão de Ciência e Tecnologia, 2011.

MAINGUENEAU, D. Análise de textos de comunicação. São Paulo: Cortez, 2002.

MAINGUENEAU, D. Doze conceitos em análise do discurso. São Paulo: Parábola, 2010.

MARTINS, A. L.; LUCA, de T. R. História da imprensa no Brasil. São Paulo: Contexto, 2011.

MATOS, C. Jornalismo e Política Democrática no Brasil. São Paulo: Publifolha, 2008.

MELLO, R. P. de. O mesmo e o outro, as relações raciais no Brasil no discurso do jornal O Globo. Tese (Mestrado) - Faculdade de Comunicação, UnB. Brasília, 2009.

MORAES, G. A tensão entre liberdade de expressão e direito à informação - empecilho à elaboração de políticas públicas de comunicação. In: ALMEIDA FILHO, A.; BARROS, V. S. de C. (Org.). Novo manual de Ciência Política. São Paulo: Malheiros, 2007. p. 260-275.

MONDAINE, A. O socialismo liberal de Norberto Bobbio, 2001. Disponível em: <http://www.artnet.com.br/gramsci/arquiv199.htm>. 
MOTTA, L. G. (Org.). Imprensa e Poder. Brasília: UnB; São Paulo: Imprensa Oficial d Estado, 2002.

MOTTER, P. A batalha invisível da Constituinte - Interesses Privados versus caráter público da radiodifusão no Brasil. 1994. Dissertação (Mestrado em Ciência Política e Relações Internacionais) - Departamento de Ciência Política e Relações Internacionais, da Universidade de Brasília, Brasília.

NOGUEIRA, M. A. N. Um estado para a sociedade civil. São Paulo: Cortez, 2011.

ORLANDI, E. P. Análise de Discurso. Princípios e procedimentos. Campinas, SP: Pontes, 2002.

OSÓRIO, P. L.A centralidade do sistema público de TVs para a implantação do marco regulatório da comunicação. In: INTERCOM - Sociedade Brasileira de Estudos Interdisciplinares da Comunicação. Grupo de Trabalho Estratégias de Comunicação, 2013.

PAULINO, F. O. Responsabilidade social da mídia. Análise conceitual e perspectivas de aplicação no Brasil, Portugal e Espanha. Tese (Doutorado) - Faculdade de Comunicação. Universidade de Brasília. Brasília, 2008.

PERUZZO, C. M. K. Rádios Comunitárias no Brasil: da desobediência civil e particularidades às propostas aprovadas na Confecom. In: Trabalho apresentado ao GT Economia Política e Políticas de Comunicação, Encontro Anual da Compós realizado na PUC-Rio de 8 a 11 de junho de 2010.

PIERANTI, O. P. A radiodifusão e a ação de policy communities: a contenção de reformas no âmbito do estado. RAC - Eletrônica, set./dez., v. 2, p. 410-422, 2008.

PIRIS, E. L. Análise do discurso e argumentação: procedimentos teórico-metodológicos para exame de jornal impresso. São Paulo: Paulistana, 2010.

RAMOS, M. C. Controle social da mídia. In: Contribuições da Psicologia para a $\mathbf{1}^{\mathbf{a}}$ Conferência Nacional de Comunicação: mídia, quem é o dono dessa voz. Brasília: CFP, 2009. p. 127-135. Disponível em: <http://site.cfp.org.br/wpcontent/uploads/2009/12/confecom.pdf>.

REBOUÇAS, E. Comunicação não deve ser confiada aos donos da mídia. Disponível em: $<$ http://www.observatoriodaimprensa.com.br/news/view/comunicacao _ não_deve_ser_confiada_aos_donos_da_midia>.

REBOUÇAS, E.; CUNHA, P. Observatórios de mídia como instrumentos para (da) democracia. Disponível em:

<http://www.reciis.icict.fiocruz.br/index.php/reciis/article/view/413>.

RIBEIRO, E. L. Um Jornal de Campanha. Campinas, SP: Komedi Editora, 2007.

RUELA, R. M.; COUTINHO, I. M. da S. O público na TV: discussões em rede nacional para a afirmação do sistema público no Brasil. In: CONGRESSO BRASILEIRO DE CIÊNCIAS DA COMUNICAÇÃO. Intercom - Sociedade Brasileira de Estudos Interdisciplinares da Comunicação, 2013. 
SADER, E. (Org.). 10 anos de governos pós-neoliberais no Brasil: Lula e Dilma. São Paulo: Bomtempo; Rio de Janeiro: Flacso Brasil, 2013.

SEABRA, R. Dois séculos de imprensa no Brasil: do jornalismo literário à era da internet. In: MOTTA, L. G. (Org.). Imprensa e poder. Brasília: UnB, 2002. p. 31-46.

SILVA, N. C. Revista Saber Acadêmico, v. 12, junho/2011.

SODRÉ, N. W. História da Imprensa no Brasil. Rio de Janeiro: Mauad, 1999.

SOUSA, J. P. Introdução à análise do discurso jornalístico impresso. Florianópolis: Letras Contemporâneas, 2004.

SOUSA, C. B. Comunicação e igualdade racial: atuação de movimentos negros na $1^{\text {a }}$ Conferência Nacional de Comunicação. 211 fl. Dissertação (Mestrado em Comunicação) Universidade de Brasília. Brasília, 2014.

SOUZA, S. E. B. L. de. Elusive Autonomy. 1998. Tese (Doutorado em Filosofia) - Escola de Jornalismo e Comunicação de Massa, Universidade do Colorado, EUA, 1998.

THOMPSON, J. B. Ideologia e cultura moderna. Petrópolis, RJ: Vozes, 1995.

TRAQUINA, N. (Org.). Jornalismo: questões, teorias e "estórias". Lisboa, Portugal: Veja Editora, 1999.

TRINDADE, A. L.; BITTENCOURT, S. da R. Manual para apresentação de trabalhos de pós-graduação. Canoas, RS: Ulbra, 2003.

VIEIRA, L. Cidadania e globalização. Rio de Janeiro: Record, 1998.

WIMMER, M. Direito, democracia e comunicação de massa: a igualdade de oportunidades de comunicação no contexto do Estado Democrático de Direito. 2010. Tese (Doutorado) Faculdade de Comunicação, UnB. Brasília, 2010.

ZAMBON, P. S.; CARVALHO, J. M. de. Confecom: processo decisório e ação dos grupos de mídia. In: ULEPICC-BR, 3º 2010. Artigo apresentado ao Grupo de Trabalho Indústrias Midiáticas, 2010. 